(i) 




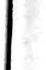

.

.




\section{bart, Stbaftner \& ftlarx Prize Economic Esøaps}

THE CAUSE AND EXTENT OF THE RECENT INDUSTRIAL PROGRESS OF GERMANY. By Earl D. Howard. THE CAUSES OF THE PANIC OF 1893. By William J. Lauck.

INDUSTRIAL EDUCATION. By Harlow Stafford Person, Ph.D.

FEDERAL REGULATION OF RAILWAY RATES. BY A]bert N. Merritt, Ph.D.

SHIP SUBSIDIES. An Economic Study of the Policy of Subsidizing Merchant Marines. By Walter T. Dunmore.

SOCIALISM: A CRITICAL ANALYSIS. By O. D. Skelton. INDUSTRIAL ACCIDENTS AND THEIR COMPENSATION. By Gilbert L. Campbell, B. S.

THE STANDARD OF LIVING AMONG THE INDUSTRIAL PEOPLE OF AMERICA. By Frank H. Streightoff.

the NAVIGABLE RHINE. By Edwin J. Clapp.

HISTORY AND ORGANIZATION OF CRIMINAL STATIS. TICS IN THE UNITED STATES. By Louis Newton Robinson.

SOCIAL VALUE. By B. M. Anderson, Jr.

FREIGHT CLASSIFICATION. By J. F. Strombeck.

WATERWAYS VERSUS RAILWAYS, By Harold Glenn Moulton.

THE VALUE OF ORGANIZED SPECULATION. By Harrison H. Brace.

INDUSTRIAL EDUCATION: ITS PROBLEMS, METHODS AND DANGERS. By Albert $H$. Leake.

THE UNITED STATES INTERNAL TAX HISTORY FROM I861 TO 1871 . By Harry Edwin Smith.

WELFARE AS AN ECONOMIC QUANTITY. By G. P. Watkins.

CONCILIATION AND ARBITRATION IN THE COAL INDUSTRY IN THE UNITED STATES. By Arthur E. Suffern.

THE CANADIAN IRON AND STEEL INDUSTRY. By W. J. A. Donald.

THE TIN PLATE INDUSTRY. By D. E. Dunbar.

THE MEANS AND METHODS OF AGRICULTURAL EDU. CATION. By Albert H. Leake.

THE TAXATION OF LAND VALUE. By Yetta Scheftel. RAILROAD VALUATION. By Homer Bews Vanderblue.

RAILWAY RATES AND THE CANADIAN RAILWAY COMMISSION. By D. A. MacGibbon.

HOUGHTON MIFFLIN COMPANY Boston AND New York 


\section{I5art, Echaffier \& Marx prize Esaazs}

\section{XXIV}

RAILWAY RATES AND THE CANADIAN

RAILWAY COMMISSION 
Digitized by the Internet Archive in 2007 with funding from Microsoft Corporation 


\title{
RAILWAY RATES AND THE CANADIAN RAILWAY COMMISSION
}

\author{
in \\ D. A. MacGIBbON, Ph.D.
}
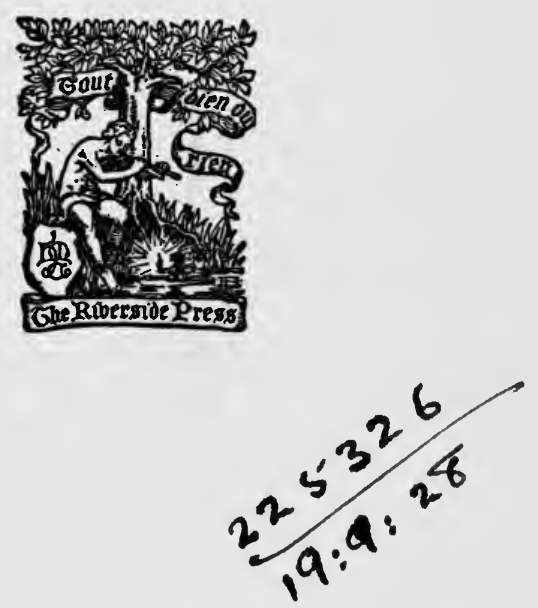

BOSTON AND NEW YORK

HOUGHTON MIFFLIN COMPANY

rebe Itiberdion fre Cambrioge

1917 
COPYRIGHT, 1917, BY HART, SCHAFFNER \& MARX

ALL RIGHTS RESERVED

Published December ror7

$$
\begin{aligned}
& 4 E \\
& 1855 \\
& 172
\end{aligned}
$$


TO

HUGH MCLEAN 



\section{PREFACE}

This series of books owes its existence to the generosity of Messrs. Hart, Schaffner \& Marx, of Chicago, who have shown a special interest in trying to draw the attention of American youth to the study of economic and commercial subjects. For this purpose they have delegated to the undersigned committee the task of selecting or approving of topics, making announcements, and awarding prizes annually for those who wish to compete.

For the year ending June 1, 1916, there were offered:In Class A, which included any American without restriction, a first prize of $\$ 1000$, and a second prize of $\$ 500$.

In Class B, which included any who were at the time undergraduates of an American college, a first prize of $\$ 300$, and a second prize of $\$ 200$.

Any essay submitted in Class B, if deemed of sufficient merit, could receive a prize in Class $A$.

The present volume, submitted in Class A, was awarded first prize in that class.

J. Laurence Laughun, Chairman, University of Chicago.

J. B. Clark,

Columbia University.

Henry C. Adams,

University of Michigan.

Edwin F. GaY,

Harvard University.

Theodore E. Burton, New York City. 



\section{CONTENTS}

\section{INTRODUCTION}

81. Purpose of the study; influence of environmental conditions and public policy on Canadian rate determinations; the scheme of treatment $\quad . \quad . \quad . \quad . \quad . \quad . \quad . \quad$. xiii

\section{PART I}

\section{BACKGROUND OF THE RATE PROBLEM}

\section{CHAPTER I}

THE DEVELOPMENT OF CANADIAN WATERWAYS

§1. Extent of Canadian waterways; their relationship to the United States .

82. The St. Lawrence route: to capture trade to England and the northeast seaboard . . . . . . . . . 6

8 3. The Rideau Canal: to give a protected highway to Upper Canada • • • • • • • • • • • • . 11

\$4. Results of the canal policy . . . . . . . . 12

\section{CHAPTER II}

\section{RAILWAY POLICY OF THE CONFEDERATION PROVINCES}

\$1. The struggle to prevent traffic going to the United States; repeal of the Corn Laws; development of railways in the United States . . . . . . . . . . .

\$ 2. The main trunk line proposal: to provide a winter outlet for Canadian traffic; to provide safe means of military communication with the Maritime Provinces

83. Construction of the Grand Trunk Railway; failure to capture traffic . . . . . . . . . . . 23

84. The Intercolonial Railway . . . . . . . . 88

\section{CHAPTER III}

\section{THE ERA OF TRANSCONTINENTALS}

81. The Pacific Railway project aims: the preesmption of Western territory; to connect British Columbia and the Dominion 
\$ 2. Construction of the Canadian Pacific Railway; controversies of 1870-80; the line built, 1880-86; development since 1886

8 3. The Grand Trunk Pacific Railway; cause: Western Canadian needs; railroad rivalries; the retention of Western Canadian traffic through Canadian ports; progress of construction

\$4. The Canadian Northern Railway; history of beginnings; present position

\section{CHAPTER IV}

\section{RESULTS OF THE CANADIAN TRANSPORTATION POLICY}

§ 1. Railway nets in Eastern and Western Canada; the barren area directly north of Lake Superior; peculiarities of the Canadian Railroad traffic sphere; waterway routes; the transcontinental situation . . . . . . . . 52

\&. The Canadian rate structure $\quad . \quad$. $\quad . \quad . \quad . \quad . \quad .58$

§. The possibilities of effective rate control . . . . . 69

\section{CHAPTER V}

\section{THE MACHINERY OF PUBLIC CONTROL OVER RATES}

\$1. Railroad rates and the common law . . . . . . 78

§. Control of rates by charter provisions . . . . . 76

§ 3. Statutory control over rates $\quad . \quad$. $\quad . \quad$. $\quad . \quad$. $\quad$. 79

$\S 4$. The Board of Railway Commissioners; causes leading to the creation of the Board; scope and powers; position in

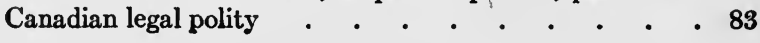

PART II

RATE REGULATION AND THE BOARD OF RAILWAY COMMISSIONERS

\section{CHAPTER VI}

RATE THEORIES DEVELOPED IN CONNECTION WITH THE CHARGE OF EXCESSIVE RATES

§1. Nature of complaints in respect to rates; three main types of appeal: excessive rates, discriminative rates, and rates against public policy 
82. The principle of fair return on "actual money invested" 101

83. Indirect criteria of reasonableness: cost data; value of commodity . . . . . . . . . . . . 123

\section{CHAPTER VII}

RATE THEORIES DEVELOPED IN CONNECTION WTTH THE CHARGE OF UNJUST DISCRIMINATION

§1. Great importance of this group of decisions . . . . 134

82. Differences in geographical location; water competition . 136

83. Competition between carriers . . . . . . 154

84. Competition for markets . . . . . . . . 156

§5. Export rates . . . . . . . . . . . 161

§6. Cost of service considerations . . . . . . . . 163

\$7. Value of the commodity . . . . . . . . . 194

\section{CHAPTER VIII}

\section{RATE THEORIES AND PUBLIC POLICY}

\$1. Rates to develop industries . . . . . . . . 201

§. Rates to protect industry . . . . . . . . . 213

§3. Rates to protect traffic . . . . . . . . . . 216

$\S 4$. Minor aspects of the Board's decisions: precedents, international rates, rehearings $\quad . \quad$ • . • . . 226

\section{CHAPTER IX}

\section{CONCLUSION}

$\S 1$. The fundamental importance of the principle of protection to investment . . . . . . . . . . . 235

§. Absence of large and effective control over discrimination 237

BIBLIOGRAPHICAL NOTE • • • • • • • • . 241

LIST OF CASES CITED . . . . . • . . . . . 249

INDEX • • • • • • • • • • • • • • • 259 



\section{INTRODUCTION}

IN the following pages an attempt will be made to exhibit the guiding principles in the rate decisions of the Board of Railway Commissioners for Canada. The aim will be to show to what degree these principles have grown naturally out of the historical and physical environment rather than to base the study solely upon the decisions. With this purpose in view the study will attempt, therefore, to trace the controlling considerations lying behind the development of Canadian systems of transportation for the light it is believed this will throw upon the problems which have faced the Board; to point out unique features of the Canadian traffic situation; to show the gradual development of means of public control; and, finally, on the basis of this survey, to exhibit, interpret, and value the body of rate principles which the Board has developed in the twelve years of its existence.

The position taken is that political and geographical factors have been the direct vital forces in shaping the development of the transportation systems of Canada. This conclusion explains, it will be shown, the peculiar condition that the rates of eastern Canada are very largely compelled rates in the sense that they are based on factors outside the scope of regulative control. Further, this view reveals reasons for the complaints of western Canadian shippers that rates in that part of the Dominion are unduly high and for the inability of the Board to grant any substantial measure of relief, or, indeed, to exert any markedly decisive influence on rates in general. It is believed that the evidence adduced will establish the soundness of this contention.

The review of Canadian transportation development, 
preliminary to the examination of the rate decisions, includes a brief history of the development of Canadian canals, of the construction of a main trunk railway line through Ontario and Quebec, and, later on, of the Intercolonial line to the Maritime Provinces. The construction of these lines, it may be noted, completed the building of the principal avenues of communication between the older Provinces of the Dominion. This is followed by similar consideration of the circumstances surrounding the inception and building of the transcontinental railways. With the exception of the Canadian Pacific Railway, however, these lines are not yet wholly out of the constructive stage, but the history of their progress is brought down to date so far as possible.

Finally, concluding this portion of the study, a general survey of the whole transportation situation in Canada is made. Attention is devoted to the peculiar shape of the area within the sphere of railway operations in Canada, and particularly to the significance, from a traffic standpoint, of the great, partly infertile, partly unexploited, territories which form a vast salient northwards to Hudson's Bay from Lake Superior and Lake Huron, a salient between the traffic regions of eastern and western Canada.

The politieal currents behind this policy of expanding means of communication might have been treated as a topic by itself. Their importance would easily warrant such treatment. It has been felt, however, that they would more naturally and clearly reveal themselves if indicated in connection with the events which they help to explain. This has been the method followed here. The endeavor has been to weave together, in an interpretative way, the various elements that account in each instance for the successive steps forward in Canada's development of systems of communication.

With this background the rise and augmentation of means of public control, in so far as it affects rates for the 
carriage of goods, is traced up to and including the creation of the Board of Railway Commissioners. The general powers of the Board are outlined. With a view to giving a correct impression as to its place in the legal polity of the Dominion, the general scope of its activities is noted, as well as its relationship to the courts of higher appeal and to the Privy Council.

The larger and latter part of the study is concerned with a detailed examination of the rate decisions of the Board. From these the conclusion has been drawn that the principles of rate-making that it has followed flow in the main out of the conditions produced by the course of Canadian transportation history combined with the natural peculiarities of the Canadian situation. Investigation reveals that the complaints the Board has had to deal with fall chiefly into two groups, those relating to excessive rates and those relating to unjust discrimination. The method pursued is to examine the principles that the Board has recognized as controlling in disposing, in each instance, of the complaints that have come before it. To this is added some consideration of cases based on larger phases of public policy, though the relative absence of cases of this nature is not the least significant feature in the whole situation. There are also considered some minor aspects of the Board's practice. The main conclusions have not been sought for, but have developed naturally as a result of the whole investigation. 



\section{RAILWAY RATES AND THE CANADIAN RAILWAY COMMISSION}

\section{PART I}

BACKGROUND OF THE RATE PROBLEM 



\section{RAILWAY RATES AND THE CANADIAN RAILWAY COMMISSION}

\section{CHAPTER I}

\section{THE DEVELOPMENT OF CANADIAN WATERWAYS}

$\S 1$. No powers of acute observation are required to discover the immense importance of water transportation in the Dominion of Canada. The earliest discoverers of the Maritime Provinces were quick to perceive the significance of their deeply serrated coasts, their large bays and secure harbors. With Prince Edward Island, completely surrounded by water; with Nova Scotia, a peninsula; with New Brunswick bounded by water on the larger part of three sides, it is no accident that all the leading towns and cities of these Provinces have developed at points where the advantages of water-borne traffic are enjoyed, and where as a result railway tolls have been largely affected by maritime competition.

Yet the Maritime Provinces of Canada possess no monopoly of waterways. Virtually the whole of the settled portions of Quebec and Ontario lie within the drainage basin of a single river, the River St. Lawrence. From the head of Lake Superior water moves by degrees, in the main through navigable channels, over two thousand miles in its course to tidewater. ${ }^{1}$ Emptying into the main chan-

1 From Fort William to the mouth of the St. Lawrence is 2384 miles. Montreal is 986 miles inland, 100 miles above tidewater. From a volume prepared under the direction of the Honorable Sydney Fisher, Canada, Its History, Production, and Natural Resources.

The difference between tidewater and Lake Superior is 602 feet. Canada Statistical Year Book (1895), p. 669. 
nel at several points along the way tributary streams, deep enough to permit, and long enough to invite, navigation, swell the volume of water that flows eastward and provide subsidiary routes. The importance of the River St. Lawrence, the Gulf of St. Lawrence, and the Great Lakes, as a system of navigable waters, has long been recognized. ${ }^{1}$ Time need not be taken upon elaborating a fact so obvious.

One element here, however, merits some notice because of the practical bearing it has upon the scope of rate regulation in Canada. This great waterway system does not lie wholly within the control of the Dominion. The Great Lakes and connecting rivers are boundary waters between Canada and the United States. Similarly, the River St. Lawrence for many miles of its course is an international stream. In consequence the advantages of this avenue of transportation, and, of more importance, the possibilities of effective regulation and control, do not belong exclusively to Canada, but are shared with a foreign country. It is necessary, however, to remember in this connection that the balance of convenience in its use lies with Canada. Where the St. Lawrence attains a depth that permits navigation by the larger ocean liners it is well within Canadian territory. Its maritime ports, Montreal and Quebec, are Canadian cities, and as such Montreal, particularly, competes with New York, an American rival, for the commerce of western Canada and of the Middle States.

The rivalry of these two cities for shipping, beginning almost a century ago, more acute perhaps in the past than in the present, is the opening chapter in a phase of national policy which has continued down to the present time and which has profoundly affected the transportation arrangements of the Canadian Provinces. For since Mon-

1 "No country under heaven is so completely adapted for internal navigation." By a Backwoodsman, Statistical Sketches of Upper Canada, p. 58. 
treal is nearer to Europe than New York, it was believed for many a day that the relatively shorter distance alone would enable the Canadian city to capture much of the traffic and therefore the trade of the Western States. ${ }^{1}$ To capture this traffic was put forward as a national duty by interested parties, who employed all the usual devices to propagate the idea that Canadian supremacy was possible in this field. The task of convincing Canadians was not very difficult. This was natural, for it was generally felt that the prosperity of the Canadian carrying trade with its collateral interests would inure to the prosperity of all Canada. It must be remembered that at this time Canada was just a slim country strung out along the lines of her waterways, that wooden ships were still in use, and that their prosperity affected the important colonial industry of lumbering. These reasons disposed people to look favorably upon schemes to improve shipping. The idea of controlling the carrying trade of a large portion of North America, therefore, obtained ready reception in the colonial imagination and easily grew into a national ideal toward which statesmen bent their efforts. This ideal to grasp and to hold the trade of the American West, not only the carrying trade, but the commerce of the West as a pendant thereto - is the key that opens up and makes

1 "We possess in Canada an undoubted and preëminent superiority in controlling and directing the productive industry of the western territories. ... The master key of the lake region is not theirs." By a Projector, A Concise View of the Inland Navigation of the Canadian Provinces, etc., p. 5 .

"So long indeed as the St. Lawrence flows to the sea, so long will the tide of commerce fall into and follow its natural declivity." William F. Coffin, The Canal and the Rail, p. 3.

"The produce of western Canada, and of the northern parts of Ohio, Illinois, Indiana, and Michigan must find an outlet either by way of the Erie Canal or by the St. Lawrence to the ocean." The Economist (London), September 12, 1846.

"They [canals] are as essential to the western states as to ourselves. The natural route to New York and Boston is by them." William Kingsford, C.E., The Canadian Canals, p. 12. 
intelligible a large part of the canal and railway legislation and construction up to the union of the Provinces in 1867. Less obvious in its workings, but more comprehensive in its design, than in the pre-Confederation period, this ideal has continued to influence the policy of the Dominion in the construction of transcontinental lines of a later era. Those things that the attempts to realize this ideal do not explain in Canadian transportation history, it will be shown, are largely explicable on the related basis of military expediency and national completeness. To the inception and early growth of transportation facilities we now turn.

\$ 2. Apparently the struggle for trade supremacy did not actually become overt until nearly as late as $1825 .^{1}$ The causes may be briefly set forth. The War of 1812-14 revealed to the Imperial Government the imperative necessity of having available safe routes within and between the various colonies in British North America by both land and water. ${ }^{2}$ The development of western Ontario was taking place rapidly through the energetic efforts of Governor Simcoe, Colonel Talbot, and other pioneers. A challenge to what was believed to be the "natural route" ${ }^{3}$ was rightly apprehended in the construction of the Erie Canal for the purposes of conveying traffic from Lake Erie to New York. ${ }^{4}$ The richness of the opportunity for trade on

1 The Ontario peninsula was scarcely developed sufficiently. The United Empire Loyalist influx followed the defeat of the British in the United States.

2 This appears in connection with the Rideau Canal.

8 "The United States Government, as well as some of its Commonwealths, are at this day busily engaged, not only in forming, but also in executing, plans, by which the trade of a great part of the Canadas, and all of the Northwest country may be diverted from its natural course, the valley of the St. Lawrence by Montreal and Quebec, and transferred to the Hudson and Mississippi by New York and New Orleans." William L. Mackenzie, The Colonial Adoocate, September 27, 1824. Cp. Henry Bliss, Statistics of the Trade of Canada, etc., etc., p. 128. See also Proceedings of a Committee appointed at Brockville the Tenth of November, 1830, on the Improvement of the St. Lawrence.

- The Erie Canal was begun in 1817 and completed in 1825. 
account of the surprising growth of the Middle Western States was rapidly increasing. ${ }^{1}$ All of these factors conspired to focus the attention of Canadians upon the St. Lawrence route. The advantages of this route were glowingly portrayed to them as a national asset the development of which would not only hasten the settlement and exploitation of their own rich possessions in what is now the Province of Ontario, but would also, levying upon the prosperity of their American neighbors, make the American Northwest tributary to Canadian cities and seaports. Hence, behind all movements to deepen and otherwise improve the St. Lawrence route, beyond the hope of direct reward, lay this ambitious scheme of national economic aggrandizement.

There is evidence that until 1800 the traffic on the St. Lawrence was comparatively light, being conveyed chiefly by batteau, Durham boat, or lumber raft. ${ }^{2}$ Before that time only two or three shallow canals on the St. Lawrence, later abandoned, ${ }^{3}$ expedited transportation between the western Ontario peninsula and Montreal. The up voyage entailed frequent portages and the journey was correspondingly long, tedious, ${ }^{4}$ and expensive. ${ }^{5}$ Natur-

1 I have not been able to verify Trout's statement that in 1795 the traffic over the portage around Niagara Falls was sixty wagons a day. J. M. and Edward Trout, The Railways of Canada, etc., p. 22. Cp. James Duncan, The Canadas as They Now Are, p. 71.

2 Isaac Weld, Voyage au Canada, vol. In, p. 213 ff.

3 Canadiana, vol. xr, p. 4.

- Weld, op. cit., p. 55.

- "The cost of carrying goods between Montreal and Kingston before the Rideau or St. Lawrence canals seems to this generation incredible, and is worthy of belief only because it is stated on unimpeachable authority. Sir J. Murray stated in the House of Commons September 6,1828 , that on a former occasion the carriage of a twenty-four-pound cannon cost between $£ 150$ and $£ 200$, and that a 76-cwt. anchor $£ 676$ and that when the imperial government sent out two vessels in frames, one of them, a brig, cost the country in carriage the short distance between these two cities the enormous sum of $£ 30,000 . "$ Trout, op. cit., p. 19. (While undoubtedly carriage was expensive, these rates were probably war rates.) .. 
ally the first attempt of importance, in the period that followed, to overcome the difficulties of the route occurred in connection with the greatest of these difficulties, Niagara Falls, an obstacle sufficiently great to delay the most resourceful navigator.

The increasing volume of freight that was compelled to break shipment at this point, involving vexatious delay, of itself with growing insistence emphasized the desirability of a canal. Yet, while the advantages of more convenient passage between Lake Erie and Lake Ontario were becoming more obvious every day and in time certainly would have been sufficient to induce the construction of a canal, there is no reasonable doubt that the approaching completion of the Erie Canal hastened the event. For the latter clearly threatened to divert a large part of the western traffic via Albany and the Hudson to the port of New York. If this diversion were successfully accomplished, it meant, of course, that the ambitious plans to capture this rich and extensive trade would be forestalled before they were mature or even partially realized. To meet this invasion, so upsetting to the preconceived notions of the people of Canada as to the necessity of the Western States finding an outlet to the sea by the St. Lawrence, there was begun a series of improvements upon that traffic route that has continued, almost without let, down to the present day.

Of these improvements easily the first in order of importance is the Welland Canal. ${ }^{1}$ This was begun in 1823, two years before the completion of the Erie, and finished some time after the latter. It was followed by a series of short canals ${ }^{2}$ along the St. Lawrence designed to obviate

1 William Hamilton Merritt, Brief Review of the Origin, Progress, Present State and Future Prosperity of the Welland Canal.

2 The Lachine Canal was opened in 1825; the Welland, partially in 1829, wholly in 1832, enlarged in 1841 and in 1859-66; the Beauharnois Canal, in 1845; the Cornwall Canal in 1843; Williamsburg, etc., in 1847; Sault Ste. Marie, in 1895; Soulanges, in 1899. 
the difficulties of the channel, particularly on the up voyage. This it was believed would effectually establish the primacy of the route against the Erie. There can be no doubt that this was the main purpose of these improvements. The Canadian people believed in their route, believed in its inherent superiority ${ }^{1}$ over its American rival. On the basis of its directness, the greater depth of channel afforded, the shortened distance from the West and from Montreal to Liverpool, and the longer St. Lawrence season, quite early in the history of the route they boasted ${ }^{2}$ that they had the "easiest, shortest, and cheapest channel to the sea."

(i) Like the completion of the Erie Canal the completion of the Welland was a notable event in the history of freer traffic facilities and intercommunication. It provided a navigable channel around the greatest and only absolutely impassable obstacle in the whole related chain of lakes and rivers. It thus enormously extended the area of territory capable of being served by the St. Lawrence ports. We must remember that the Welland Canal was opened before railroads appeared as active factors in the conveylance of goods and passengers. With its completion Canadians possessed an easy, safe, and relatively cheap avenue of intercourse between the Western States and their chief cities. This advantage, in itself no small matter, was enhanced by the fact that the operation of the Navigation Laws made it an exclusive advantage, for they restricted the use of Canadian canals to Canadian vessels. ${ }^{3}$ The

1 Hon. Francis Hincks, M.P., Canada, its Financial Position and Resources, p. 5. Cp. Bliss, op. cit., p. 133.

"Examination convinces them that with the St. Lawrence as a highway and Portland as an outlet to the sea, we shall be enabled successfully to struggle for the mighty trade of the west, and bid defiance to competition on the more artificial route of the Erie Canal." Sir Richard Henry Bonnycastle, Canada and the Caradians, vol. II, p. 292. (The author is quoting from a pamphlet of the Free Trade Association of Montreal.)

2 See Bliss, Coffin, op. cit. The whole literature of the period is full of this confidence.

These restrictions were removed in 1849,12 \& 13 Vic., c. 29 . 
practical result, therefore, was that American towns on the south shore of Lake Ontario or of the St. Lawrence, which wished to engage in the profitable Western trade, must needs employ Canadian vessels. The whole interlake as well as the export carrying trade seemed securely in the hands of shipping interests located on the Canadian side of the boundary. With regard to the export trade, however, Canadians had yet to learn that excellent inland communications alone were not sufficient to turn the scale in favor of one route over another. As Keefer points out, "Both Upper Canada and Lower Canada were under the delusion that equal facilities in the shape of artificial navigation would give the St. Lawrence with its short canals the advantage over the Hudson with its long ones." 1 They underrated the influence of low ocean rates, a factor which presently entered into the competitive situation and which to some degree had been overlooked by Canadian interests.

The construction of canals along the Richelieu River exhibits an extension of this struggle between routes. If Canada hoped to dominate in the carrying trade between the Eastern and Western States, she must find a way for traffic to pass easily between New England and the St. Lawrence. This would finally cut the trade away from the towns on the southern shores of Lake Ontario and the St. Lawrence and make Canadian ports the gateway cities to the West. Nature had already provided the possibility of an easy avenue of communication. The Richelieu River, flowing from Lake Champlain to the St. Lawrence just below Montreal, except at a few points was a navigable stream and its use antedated the loss of the thirteen colonies. It was now determined to make it completely navigable by the construction of canals and locks where necessary. Accordingly, the next step to be noted is the construction of the Chambly Canal, which was begun in

1 T. C. Keefer. C.E., Eighty Years' Progress of British North America, p. 179. 
$1843,{ }^{1}$ and later of the St. Ours. These two short canals provided the necessary easy access to Lake Champlain. From Lake Champlain by the Hudson the way was open to New York, which would be the destination of much Western traffic and the source of return cargoes. With this link complete, Canada was in a position seriously to bid not only for export business, but for interstate American trade. The completion of these canals, accordingly, marks the close of an era. It marks the conclusion of Canada's first attempt to bring the carriage of through East and West traffic under Canadian control.

\$3. While military rather than commercial considerations account for the construction of the Rideau Canal, it deserves mention here. This cross-country canal, between Kingston and Ottawa, connects Lake Ontario and the Ottawa River, and was built after the War of 1812-15 by the Imperial Government. The latter sought to provide a safe route from Montreal to Kingston for the transportation of supplies and the military in case of another war with the United States. Events had shown that the St. Lawrence could not be relied upon, as it came almost immediately within the war zone. ${ }^{2}$ It need scarcely be pointed out that Kingston at that time was relatively a much more important city in the life of Canada than it is to-day, and it was eminently desirable in case of a naval defeat upon the Lakes, as well as from the standpoint of uninterrupted communications, that there should be some Lake port with a safe line of retreat in the rear. The building of the Rideau Canal involved as a necessary adjunct the construction of locks and canals along the Ottawa River between Ottawa and Montreal to make possible a complete utilization of the route. There thus came into

1 The authorization was given earlier: 3 Geo. IV, c. 41 (1823); \& Vic., c. 61 (1839); 3 Vic., c. 20 (1840).

2 The Rideau Canal was built by the Imperial Government because it desired to retain complete control over it in case of war. Keefer, op. cit., p. $154 \mathrm{ff}$. 
being a secondary and alternative route from Montreal to the foot of the Lakes. Incidentally the range of waterway transportation was considerably extended, no small boon at this period, though the advantages were chiefly to be reckoned in terms of local traffic.

$\S 4$. The canal systems of Canada were in a great measure complete by 1846. ${ }^{1}$ Channels have been deepened, locks have been lengthened, further links added by a number of short canals having been constructed; but with one exception ${ }^{2}$ these additions and improvements have had to do with existing systems, amplifying them and extending the range of their service. Consequently the time has come when the results of this policy, not only in the light of the conditions that obtained when it was inaugurated and carried to practical issue, but with regard to the effective influence that these canals exert to-day, may be conveniently discussed. In the first place, it is clear that the period between 1820 and 1846, the time of activity in canal construction, coincides with a great development of commerce and navigation on the Great Lakes. ${ }^{3}$ Lake shipping achieved, perhaps, its highest point of importance (though not necessarily its greatest development) at that time, while the St. Lawrence, with the Erie and Welland Canals, provided the essential links between East and West. As against the competition of the Erie the Canadian design of capturing the major portion of this trade seemed within some degree of realization. The traffic upon the St. Lawrence, in spite of the competition of the rival route, was doubling every four years. ${ }^{4}$ Trade conditions in Canada in the forties were highly satisfactory. Canadians, not content with diverting traffic from

1 The Rideau Canal was opened in 1832.

2 St. Peter's Canal, in Cape Breton, was opened in 1869.

8 James Croil, Steam Navigation and its Relation to the Commerce of Canada and the United States (Toronto, 1898), p. 252 ff. Cp. " Lake Erie appears like a frequented track on the highway of waters." Martin, loc. cit.

- J. Sheridan Hogan, Canada, p. 24. 
the earlier opened Erie route, looked forward with assurance to the complete achievement of their aims in a virtual monopoly of the trade. This seemed the more certain for the privileged position that Canada occupied in the markets of Great Britain before the repeal of the Corn Laws concealed the disabilities of the St. Lawrence sea route: the higher freight rates from Canadian ports were more than counterbalanced by the preferential colonial duties. There is no question that the waterway system of Canada at this time procured a remarkable degree of prosperity to a large and important element in the commercial life of the country. In point of fact, though, it is difficult to determine how much diversion of trade actually took place. Some, no doubt, took place, but the true significance of the situation seems to be that the development of the Middle West was so rapid that it placed heavy burdens on all available transportation facilities to the East. For our purpose the more important fact to notice is that at this period the great expenditures ${ }^{1}$ which had been incurred in improving Canadian waterways seemed to have been viewed as justified in the light of their results. Canadians were therefore confirmed in their belief that they possessed a route inherently superior to that possessed by the United States.

Let us turn now to the effect of this legacy of transportation facilities upon Canadian traffic problems of to-day. In the first place, it is to be observed that the canal systems of Canada, in the main, have made for a fuller utilization of vast stretches of preëxisting waterways. A canal mileage of one hundred and eighteen miles connects and makes available for continuous voyage nearly sixteen hundred miles of lake and river. ${ }^{2}$ This widely extended system

1 Before Confederation in $1867, \$ 20,593,866$. Total capital expenditure for construction and enlargement of canals to 1913, $\$ 104,152,119$. Canada Year Book (1913), p. 478.

2 Canal Statistics for the Season of Navigation (1914), p. 98. 
of water transportation is at present in operation and is a permanent element, as a competing means of carriage, in the rate situation of the Dominion. This may readily be seen if we turn to the latest figures for items of freight carriage passing through Canadian canals. To avoid the disruption in trade caused by the Great War the following data are taken from the Canada Year Book for 1913. For the calendar year 1913 the total volume of traffic through the canals of the Dominion amounted to 52,053,913 tons. These are gross figures; net business is placed at $44,901,804$ tons. The discrepancy is due to the statistical system that has long been in use in Canada, by which, in the case of the longer freight movements, the same traffic is recorded at different points in the voyage. Thus traffic between Fort William and Montreal is first credited to the canal at Sault Ste. Marie, then to the Welland Canal, and finally to the St. Lawrence canals. A glance at the individual systems shows that by far the largest traffic goes through the Sault Ste. Marie Canal. ${ }^{1}$ Out of this volume $32,419,242$ tons consisted of iron ore moving from the head of Lake Superior chiefly to ports on Lake Erie. Canal traffic in Canada in 1913: -

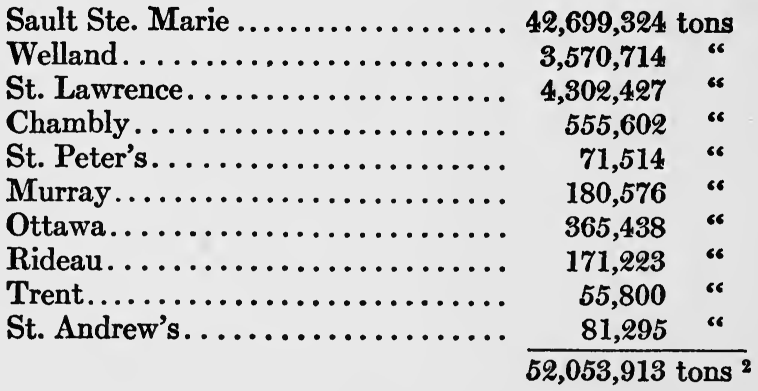

1 Canal Statistics for the Season of Navigation (1914), p. 102, gives full information regarding this extension of the St. Lawrence-Great Lakes system. The canal was first opened for traffic in 1895.

2 Canada Year Book (1913), pp. 464-72. 
In round numbers there was an increase of freight tonnage for the year over 1912 of about 5,000,000 tons. ${ }^{1}$ These figures show that the canal systems of Canada are by no means obsolete as traffic carriers even if the greater weight of traffic is carried by the railroads. Moreover, in the more important systems there is convincing evidence that the complete utilization of these facilities rests upon traffic moving between American points. Thus in 1913 there were $36,325,011$ tons of traffic of this nature. The sharp decline in this traffic in 1915 to $5,353,726$ tons, due in part to the completion of a superior lock on the American side at Sault Ste. Marie, makes this conclusion very clear. The United States is in no wise dependent upon $\mathrm{Ca}-$ nada for her means of transportation, but has competing routes of her own, capable of diverting Canadian traffic. This indicates a limitation on the effectiveness of rate control in Canada. In the nature of the case the Canadian Government can exercise no control over rates on the competing foreign routes. It lacks jurisdiction. Hence, the great system of transportation by water built up by Canada as a national enterprise, because it does not lie deep within Canadian territory with a secure monopoly of traffic and Canadian control of other avenues of freight carriage, but exposed to the competition of a foreign neighbor and foreign routes, is a disturbing factor in the regulation of rates to transportation. The fact that Canadian canals have been made free of toll since 1903 does not disturb this conclusion. It simply means in effect that a possible method of regulation through the adjustment of canal tolls to harmonize them with railway rates has been foregone. In the face of the difficulties already referred to

1 For the year 1914 the total volume of traffic through the canals of the Dominion amounted to $37,023,237$ tons; for the year 1915, 15,198,803. In both years the decline has largely been at the Sault Ste. Marie Canal, a factor in 1915 being the diversion of traffic to the American canal through the availability of a new and larger lock on the American side. Canada Year Book (1915), p. 490. 
it is probable that this was the wisest course. But at the same time this does not invalidate the conclusion that in so far as the canal systems have proved to be competing, unregulated systems of transportation, they have aggravated the acuteness of the general railway rate problems which come before the Board of Railway Commissioners for solution. The cardinal importance of this proposition will develop as the cases which have come before the Commission are reviewed. 


\section{CHAPTER II}

\section{RAILWAY POLICY OF THE CONFEDERATION PROVINCES}

$\S 1$. The preceding survey of canal development clears the way for the consideration of a long period of railway policy. This centers around the great project of uniting the Provinces of eastern British North America by one continuous line of rail. Though not on the surface, behind this idea are disclosed the same driving forces that were dominant in the construction of Canadian canals, to wit: the determination to share in the carrying trade of the West ${ }^{1}$ and the felt necessity of uniting the colonies for military security. ${ }^{2}$ In the event these two ideas became disunited and their outworking can be observed in connection with two projects which came to be viewed as separate. These projects, for convenience, may be studied apart. They are the construction of the Grand Trunk and of the Intercolonial Railways; the former put forward by the Province of Canada and the latter a project also involving the Maritime Provinces and the Imperial Government. Of the two the Grand Trunk scheme came to completion first and may now be considered.

Scarcely had the Canadian Provinces begun to enjoy the fruits of their ambitiously conceived canal policy when an event occurred in England which, as a secon-

1 James Buchanan, Letter to His Excellency Sir Francis Bond Head, etc. Cp. Keefer, op. cit., p. 197.

"It became evident unless Canada could combine with her unrivaled inland navigation a railroad system connected therewith and mutually sustaining each other, the whole of her large outlay must forever remain unproductive." Hon. A. T. Galt, Minister of Finance, Canada, 1849 to 1859 , p. 22.

2 Earl of Durham, Report of the Affairs of British North America, p. 114. 
dary result, put to the test the pretensions of the St. Lawrence route. This was the fall of protection. In 1846 the repeal of the Corn Laws enabled American grain from American ports to enter Britain on precisely the same terms as the colonial product. It has already been pointed out that until that time the ports of Montreal and Quebec had derived adventitious aid from the British Navigation Laws.

Preceding the repeal of the Corn Laws, regulations, varying from time to time, governed the importation of corn into Great Britain. These regulations had granted a substantial preference to corn entering the mother country from British North America. As a result of this preference much American wheat had entered Canada in the West and later had indirectly gone to swell the total of exports to Great Britain. Canadians found it profitable to ship their own wheat to the mother country and rely upon American importations for their own supply. Moreover, American wheat was imported into Canada and ground into flour which later found a market across the ocean. ${ }^{1}$ This practice had grown up under a rule laid down in the English courts, and later confirmed by statute, that all manufactured goods should be deemed to be the produce of the country in which they were manufactured. ${ }^{2}$ The repeal of the Corn Laws took away the practical value of this ruling and the loss of this advantage was in itself a severe blow to the Canadian millers and forwarders, who were slowly learning that the success of a route did not rest entirely upon the ease with which goods could be conveyed to the tidewater terminal, but also upon the freight and insurance rates which could be secured from that point to the markets of the world. They were compelled to recognize that the difficulties and dangers of navigation in the St. Lawrence and Gulf, involving higher charges

16 Vic., c. 31, Canada (1843); 6 \& 7 Vic., c. 29, Great Britain.

2 Bernard Holland, The Fall of Protection, pp. 16, $118 \mathrm{ff}$. 
than to New York, was an element in the struggle between the two routes and their ports. ${ }^{1}$

§2. The drastic adjustments made necessary in Canadian trade by the repeal of the Corn Laws, though they contributed to the decline in relative importance of the St. Lawrence route, in the final result were not the real forces that undermined the supremacy claimed for it. The advent of direct and convenient lines of railways into the Middle Western States struck the decisive blow that was fatal to the hopes of a monopoly in the carriage of grain for export, or indeed of the longer hauls of any sort. Henceforth the burden of effort was shifted from that aim to the less ambitious one of enlarging and improving the Canadian system of transportation already developed with a view to protecting the heavy capital investments placed therein. ${ }^{2}$ Canadian statesmen and commercial leaders saw that they had a new and much more difficult factor to contend with now, one that at the outset took the strain of pace-making off American shoulders and placed it upon their own. ${ }^{3}$ Instead of a direct route by water competing with a less convenient one of the same nature, railroads provided an equally direct line of a more convenient nature to the American seaboard. Not only did this condition make necessary that American competitive rates should be met to the city of Montreal, but it made the additional demand of an outlet to another port that would not be unavailable for four or five months in the year. In this respect the superiority claimed for the Welland Canal over the Erie, because it was open a month longer in the year ${ }^{4}$

1 "The reason why Western traders keep aloof from the St. Lawrence can only be found in the relative prices of transatlantic freight from New York and Quebec." C. Donlevy, From the Journal de Quebec, The St. Lawrence as a Great Commercial Highway, p. 23.

2 Galt, op. cit., p. 19.

8 Edward Jenkins, M.P., Agent General of Canada, The Times and Mr. Potter on Canadian Railways, p. 8.

- "It seems to be considered certain that the States of Maine, Vermont, and portions of New York and Massachusetts will receive a large share 
than its rival, was wiped out by the new avenues of access to New York, a port open throughout the winter while the Canadian channel was blocked with ice.

The rapid growth of Upper Canada stimulated the movement for an extensive system of railway lines to meet the new peril. Financial magnates as well as commercial leaders scented large profits in the construction of railroad lines, and helped to exploit national sentiment. There was thus produced the familiar phenomenon of a fusion of selfish interest, united in a single demand, and skillfully fastened upon the proper ambition of national growth and integrity. 1 The first railroads in the Canadian Provinces had been local in aim and were in the nature of feeders or portage lines complementary to the waterways. ${ }^{2}$ The demand that now crystallized was for a main trunk line that would, to quote Hon. A. T. Galt, enable Canada, to "combine with her unrivaled inland navigation a railroad system connected therewith and mutually sustaining each other." Thus it was the destiny of Canada that the conditions outlined above were to result in the fact that the first great railroad built on Canadian soil was to be planned with a view, not to independent economic development and success, but with a view to intimate connection with another method of transportation then just beginning to reveal its inflexibility to modern re-? quirements.

At its inception the scheme of a main trunk line included

of their breadstuffs and provisions by the Welland and St. Lawrence Canals which will be open on the average a fortnight earlier and later than the Erie Canal." Hon. Francis Hincks, M.P., Canada, its Financial Position and Resources, p. 5.

1 Cp. Gustavus Myers, History of Canadian Wealth, vol. I, chap. $\mathrm{x}$ ff.

2 While a number of charters had been granted, there was only sixty miles of railroad actually constructed before 1850 in Quebec, none in Ontario, or New Brunswick, or Nova Scotia. See Canada Year Book (1912), p. 304. Trout, op. cit., p. 33, gives a lively description of the first locomotive used in Canada on the Champlain and St. Lawrence Railway, chartered in 1832. 
an outlet at Halifax. The extension to the Maritime Provinces, it was argued, would perform the double service of providing a winter outlet for Canada and of meeting the desire of the Imperial Government to have a military road between the seaboard and Ontario and Quebec. The circumstances under which this design developed into a separate project are so entangled with the greater enterprise of a main trunk line that they are best set forth at once. Before the latter scheme came to the front, the British Government had employed a military engineer to survey a route from Halifax to Quebec. ${ }^{1}$ The route selected, in deference to military considerations, lay along the coast line of New Brunswick remote from the city of St. John, the chief center of trade in the Province. An earlier proposed route had been in a more direct line to Quebec along the American boundary through territory that was afterwards declared to be the possession of the United States. ${ }^{2}$ Subsequent proposals for a line skirting the Maine boundary were rejected because such a line would be unsuitable for military purposes. ${ }^{3}$ St. John and central New Brunswick had close commercial relations with Portland across the American border and desired railway connections with that city. Moreover, the people of New Brunswick were in no mood to contribute to the construction of an intercolonial line of railway which would pass through a sparsely settled portion of the Province and terminate at a Nova Scotian seaport.

Affairs were in this state when Earl Grey, Colonial Secretary, in reply to Hon. Joseph Howe, of Nova Scotia, offered, on behalf of the Imperial Government, financial accommodation that would enable a line to be built in accordance with the military survey. He also sanctioned the building of the European and North American line, a

1 Major Robinson in 1848, Final Report, etc.

2 By the Ashburton Treaty, in 1848.

- Vide Major Robinson's Report. 
lateral branch from the proposed intercolonial line to the American border. Howe construed this sanction into a promise of aid, and on the strength of his representation of Earl Grey's offer it was believed that the Imperial Government could be induced to stand behind the greater scheme of a complete line from Windsor, opposite Detroit, to Halifax. ${ }^{1}$ Howe, as a Nova Scotian, was of course deeply interested in such a consummation, and his good offices in connection with the European and North American line, which would give New Brunswick a railroad from St. John to Portland, were solely with a view to swinging New Brunswick into line on the intercolonial project. In this he was successful.

As a result the Legislature of Canada passed an act in 1851 which provided for three eventualities: $(a)$ the construction of an intercolonial railway from Halifax to Quebec in conjunction with Nova Scotia and New Brunswick on a loan under imperial guarantee; $(b)$ the continuance of the Intercolonial as part of the main trunk line to Hamilton or to connect with the Great Western Railway at Niagara, if the imperial guarantee were obtained; if it were not obtained, the continuation of the main trunk line jointly by the Provinces of Upper and Lower Canada with the aid of municipal corporations; $(c)$ if these plans miscarried, to construct the main trunk line under an act passed in $1849^{2}$ whereby the Government agreed to guarantee the bonds of railroad companies after one half of the line had been constructed, provided it was at least seventy miles in length. ${ }^{3}$

After this act was passed, Hon. Francis Hincks, Inspector-General for Canada, prepared to visit England to arrange finally details of the plan with the delegates from

1 Appendix to the Sixteenth Volume of the Journals of the Legislative Assembly of the Province of Canada. Appendix No. 49. Memo submitted to the Imperial Government. Cp. Sir Francis Hincks, Reminiscences of My Public Life, p. 201. Hon. Joseph Howe, Speeches and Public Letters, vol. II, p. 447 .

214 \& 15 Vic., c. 73 (1851). 812 Vic., c. 84 ; 12 Vic., c. 29 (1849). 
the Maritime Provinces and the Imperial Government. ${ }^{1}$ In the meantime, however, a note from the Colonial Secretary informed the Canadian Governments that imperial sanction to the lateral branch to the Maine border did not carry with it a guarantee of financial assistance for that part of the project. Though bitterly disappointed, the colonies agreed to unite in the construction of the Intercolonial along the valley of the St. John River, and with this understanding Hincks sailed to England. What negotiations took place with the Colonial Office to secure the validation of this new plan is a subject of controversy. This much, however, is clear. The new route, suddenly agreed upon by the Canadian Governments, was repugnant to the people of Nova Scotia and Howe did not appear in London to carry the scheme through. Under the circumstances an impasse occurred and Hincks abruptly broke with the Colonial Office to enter into negotiations with a prominent firm of contractors and railway promoters, for the building of the main trunk line proper, the project in which Upper and Lower Canada were particularly interested. In this way the two schemes fell apart and despite the efforts of Nova Scotia the Intercolonial scheme drifted into the background of public affairs. England became engrossed in the Crimean War and the Indian Mutiny. Only threatened complications with the United States arising out of the American Civil War renewed her interest in the project. ${ }^{2}$

§ 3. When Hincks was in England, Canadian railway projects were looked upon with considerable favor - "as a gamble or an investment." 3 The main trunk-line scheme attracted the attention of a firm of prominent contrac-

1 Appendix No. 49, Journal of the House, vol. 16. Cp. Pope, Memoir of the Rt. Hon. Sir John A. MacDonald, vol. I, p. $107 \mathrm{ff}$.

2 On the Military and Commercial Importance of Completing the Line of Railway from Halifax to Quebec, to which is added Official Correspondence, etc.

8 Thomas Storrow Brown, History of the Grand Trunk Railway of Canada, p. 40. 
tors ${ }^{1}$ who made arrangements with Hincks both to construct the line and to promote the company. Accordingly, on the latter's advice the Canadian Parliament passed three measures in November, 1852, to implement the agreement. $^{2}$ These measures provided for a Canadian guarantee of $£ 3000$ to the mile, the amalgamation of a number of existing charters and the incorporation of the Grand Trunk Railway, the stock of which the contractor undertook to dispose of. The enterprise was launched with great éclat as a national undertaking; the Premier and other members of the Administration became directors. Hon. John Ross, Solicitor for Canada West, was elected president. The project was regarded as "a noble enterprise intimately blended with the hopes of Canada," possessing a "character which took it out of the category of ordinary speculations." 3 Under the circumstances the contractors had an easy time marketing the stock. The first block offered to the public was oversubscribed three times. ${ }^{4}$ The position of the investors was made even more secure by an act passed on the advice of the contractors which prevented the pledging of the credit of Canada to any other railway enterprise. ${ }^{5}$

With apparently everything in its favor the Grand Trunk Company took up the task of providing Canada ?' with a main line which, it was fondly hoped, would put the colony once more on even terms with its American rival. Then followed an orgy of extravagant railroad building. 6 There was a perfect riot of wastefulness in which unfortunately the Grand Trunk was not alone.?

1 Messrs. Peto, Brassey, Betts \& Jackson.

216 Vic., cc. 37, 38, 39.

3 Statements, Reports and Accounts of the Grand Trunk Co., of Canada, Laid before the Legislative Assembly, April 23, 1857, p. 71.

- Brown, op. cit., p. 17.

18 Vic., c. 33 (1855).

- See Report of the Commissioners Appointed to Enquire into the Affairs of the Grand Trunk Railway.

7 Myers, op. cit., gives a lurid account of the railroad jobbery of this period in chap. $x$ ff. 
Under a municipal loan act towns and cities were enabled to pledge their credit for railroad enterprises. ${ }^{1}$ They did so to an alarming degree to secure connections. Towns and villages borrowed recklessly and ultimately created a situation that compelled state intervention." "The years of 1852-57 will ever be remembered as those of financial plenty and the saturnalia of nearly all classes connected with railways." 3 In the case of the Grand Trunk the $\sqrt{ }$ natural result was that it was soon in deep waters. Repeatedly ${ }^{4}$ the Provincial Government was forced to come to its aid. The Government could not permit the enterprise to collapse lest such an occurrence should destroy Canadian credit, particularly since the appearance on the directorate of members of the Government had given color to the contention of English investors that the Grand Trunk was distinctly a national undertaking. ${ }^{5}$

Conditions failed to improve as the line approached completion. The traffic that it was expected to carry did not materialize. This was the more disappointing to the investors in view of a circumstance that appeared when the line was finally mapped out. It will be recalled that originally it was projected with a view to coöperating with the St. Lawrence in obtaining and carrying through traffic. The public sentiment behind such an idea, strengthened by Canada's experiments in waterway improvement, was

116 Vic., cc. 138, 213, 22.

2 See Sir Oliver Mowat's speech in the Ontario Legislature, March 7, 1873.

8 Keefer, op. cit., p. 221 .

4 The principal acts by which aid was extended were: 18 Vic., c. 174 (1855); 19-20 Vic., c. 111 (1857); 20 Vic., c. 11 (1857); 22 Vic., c. 52 (1859); 25 Vic., c. 56 (1862).

5The London Quarterly Review (January, 1861) refers to "the complete collapse of this gigantic undertaking." Cp. First Report of the Select Committee of Share and Bond Holders, etc., including a Petition to the Legislative Assembly of Canada, February 6, 1861. Statements, Rejun:s, and Accounts laid before the Legislative Assembly, April 23, 1857, loc. cit., p. 71. "Canadian Credit Securities," issued by Taunton \& Molyneux. H. Allan, The "Times" and Its Correspondents on Canadian Raiiways. 
very strong. But when the question came up as to the location of the line it was laid out without regard to the idea of coöperation, or to the independent development of Canada. It was to be a through line pure and simple. Directness of connection between East and West was made the controlling consideration. The standing committee of the Legislature, which validated the change, held that the "true interest of the Province would be best consulted by adopting the most direct route." 1 In consequence the railway paralleled the St. Lawrence from Kingston to Montreal. This important change in policy was really due to the promptings of the English directors. These gentlemen had seen railways supplant canals in England and they believed that the same triumph would be repeated in Canada. They had no interest in the utilization of existing investments in canals; and, paying the piper, they were able to call the tune. Thus ultimately the Grand Trunk appeared as an independent competitor of American railroads and of Canadian canals. In addition to these competitors it had to face the competition and hostility of the Great Western Railway, an important line in the western Ontario peninsula. ${ }^{2}$

The consequences were that, while the Grand Trunk diverted a small share of the through traffic from American lines, it mainly affected the St. Lawrence and supporting canals. The logic of the situation was simple. American railway lines were injuring the business of the St. Lawrence route. To retain this carrying trade the Cana-

1 Trout, op. cit., p. 61. See Keefer, op. cit., p. $206 \mathrm{ff}$. The effects of this policy are very fully set forth in the Report of the Commissioners Appointed to Enquire into the Affairs of the Grand Trunk Railway. Jenkins, writing to the Times in 1875, said, "English directors have been making their experiments of competition with the Americans." The Times and Mr. Potter, supra, p. 8.

28 Vic., c. 86 (1845). Built largely between 1853 and 1856 from the head of Lake Erie to Burlington Bay and Niagara to compete with the Welland Canal. Charles Stuart, C.E., Report on the Great Western Railway, September 1, 1847. 
dian Provinces planned the Grand Trunk and thought thereby to protect their capital investments in canals as well. But the English influences behind the project managed to dictate a policy to the Legislature which looked to the complete absorption of through transit traffic by the rail route. This policy fell far short of success. In its working out it resulted in a lower volume of traffic to each Canadian system with correspondingly scanty returns. 1 It may be observed that, without the added complication that the change in railway policy produced, the attempt to assist the canals by a through line of railway could not give very great promise of success. In so far as the Grand Trunk could divert trade from the American lines which had been encroaching upon the traffic of the route by water, it would to that degree be in a position to inflict the injury itself. As it worked out, however, there was not sufficient traffic offered for carriage to enable the Grand Trunk to become a paying proposition. ${ }^{2}$ The inevitable result was that the company was soon in difficulty and continued to be in that state from 1855 until 1862 when the company made default of interest payments on its bonds and the directors threatened to close the road. The Government came to its rescue, supplementing its pre-

1 "It is a fact rather eschewed by the two critics that the Great Western and Grand Trunk were both built with a main view to through traffic from the West to the ocean and less as Canadian lines proper." The Times and Mr. Potter, supra.

2 "As long as the St. Lawrence flows from the western lakes to the ocean at certain seasons of the year and for bulky articles of which the exports of America principally consist the water must continue to carry them at rates which would be ruinous to a railway.... Y Yet from the inception of the Grant Trunk almost down to the present time the policy has been to run in competition with the water - to regard it as an enemy rather than as a most efficient ally. With the exception of Toronto there is not a point from one end of the road to the other, where the object has not been, and we believe avowedly, to render communication with the water difficult and inconvenient - to run for more than three hundred miles, within a mile or two at most of the navigation and yet have no points where the two routes come in contact or can exchange traffic." Report of the Commissioners to Enquire, etc., supra, p. 43. 
vious loans by permitting the issue of second preference bonds and withdrawing its interest claims on its loans until dividends were earned on the common stock. This meant a considerable scaling-down of fixed charges, for the Government advances to the road amounted to £3,$111,500 .{ }^{1}$ Finally, when this did not avail in 1862 the company was reorganized and its bond issues converted into preferred stocks. ${ }^{2}$

The failure of the Grand Trunk to capture the Western trade at the outset, and the futility of it employing its equipment in fighting the route by water gradually drove it into a safer policy. Through connections to Chicago enabled it to bid more effectively for long-haul traffic; ${ }^{3}$ feeders in Ontario developed the local service; the St. Lawrence \& Atlantic, a Portland connection, was practically rebuilt and became an important part of the line. ${ }^{4}$ In this way the Grand Trunk Railway repaired initial defects in location and policy to some extent. In 1884 it absorbed the Great Western Railway and further strengthened its position, ${ }^{5}$ though thereby becoming knit more closely than ever to conditions affecting transportation in the United States. Thus, so far as the Grand Trunk is concerned there has been bequeathed as a legacy to posterity a rate situation complicated by the double factors of waterway competition and intimate and competitive relationships with foreign lines, through its Chicago and Portland connections.

$\S 4$. The considerations which had finally to do with the construction of the Intercolonial Railway concerned almost exclusively the political future of the British colo-

122 Vic., c. 52.

2 In 1862, when the Grand Trunk was reorganized (25 Vic., c. 56) and provision was made for raising $£ 500,000$ for equipment.

8 Provided for by the Act of 1858.

- The St. Lawrence \& Atlantic was secured in 1853 (18 Vic., c. 33). The Report of the Commissioners points out that it might have been obtained at fifty per cent discount (p. 113).

47 Vic., c. 52. To prevent possible relations between the Great Western and the Canadian Pacific Railway. 
nies in North America. Reasons of trade and commerce appear as subsidiary advantages, but political stability and military expediency were the ends which actually achieved the consummation of the scheme. As early as $1832^{1}$ a railway was projected between St. Andrews, on the Bay of Fundy, and the city of Quebec, but it was Lord Durham, in his celebrated report, who put the necessity of intercolonial connection squarely before the British Government. ${ }^{2}$ After the break in negotiations in 1852, which has already been dealt with, each colony for a while followed its own devices in railroad building. While the construction of the Grand Trunk Railway was occupying the attention of Canada (i.e., Ontario and Quebec), New Brunswick, with a view to obtaining New England connections, was constructing a line toward the Maine border. ${ }^{3}$ Nova Scotia had not given up hope that time would make an intercolonial system a reality and was building northwards in the general direction of New Brunswick. ${ }^{4}$ One might imagine, after the previous fiasco, that the probability of an intercolonial system being actually achieved was decidedly remote, if not altogether unlikely.

Public men, however, continued to canvass the possibility of such a route and to discuss its advantages. Finally, by mutual agreement, negotiations were reopened, though at first with small success. But a beginning had been made and in the end delegates proceeded to England to interview the Home Government. In the meantime events were occurring that were greatly increasing the possibility of the success of their mission. Their arri-

1 Journal of the House of Assembly of Lower Canada, 1835-36, p. 282 (N.B.) $6 \mathrm{Wm}$. IV, c. 31 (1836).

2 Lord Durham's Report, p. $113 \mathrm{ff}$.

3 N.B., 17 Vic., c. 1. See also Report of Survey and Extension of the European and North American Railway to the American Boundary and Branch Line to Fredericton. Also Reports of the Railway Commissioners of New Brunswick.

- N.S., 17 Vic., c. 1. Nova Scotia had built a hundred and forty-five miles before Confederation in $\mathbf{1 8 6 7}$. 
val in England coincided with the Trent affair, and the unhappy relations existing between Great Britain and the Northern American States combined with the repeal of the reciprocity treaty and the Fenian agitation to lead Her Majesty's Government to lend a sympathetic ear to the project. ${ }^{1}$ At the same time political deadlocks in Canada had thrown the issue of Confederation into the field. In their desire to achieve Confederation the statesmen of Canada made the construction of the Intercolonial Railway a part of the compact to induce the Maritime Provinces to enter into the union. The Intercolonial Railway thus became the seal of intercolonial unity while it satisfied Canada's desire for winter ports and Great Britain's felt necessity for military communications. By clause 145 of the Act of Confederation the Government of the Dominion of Canada bound itself to construct the road within three years, while the Imperial Government gave a guarantee of $£ 3,000,000$ for a line "approved by one of Her Majesty's principal Secretaries of State.” 2

This agreement left the power of determining the route to Great Britain, for the road could not be financed without the imperial guarantee and the imperial guarantee rested upon an approval of the route chosen. As the British Government, under the ruling preconception of free trade, was interested only in the military advantages of the route, this vexed problem was settled by the choice of the northern line which followed very largely the course recommended by Major Robinson in $1848 .^{3}$ It was clearly

1 Sir E. W. Watkin, who was present at the delegates' interview with Lord Palmerston, gives a vivid picture of the influence of the Trent affair upon the situation. Canada and the United States, Recollections by Sir E. W. Watkin, Bt., p. 83 ff.

230 \& 31 Vic., c. 3 ; c. 16 (1868).

Copy, Canada, 155.

My Lord: -

Downing Street, 22 July, 1868.

I have received your lordship's telegraphic message that the route by way of Bay of Chaleur has been selected by the Canadian Government 
recognized that this route would offer few advantages from the standpoint of traffic. Traffic considerations, however, were forced to give way before the requirements of the Imperial Government for a line accessible to the sea and remote from the American boundary. ${ }^{1}$ Such a line, while linking the Provinces together, would enable Great Britain to reduce the size of its military establishments at Halifax and Quebec. Thus in times of peace the line would lighten the burden of military expenditure in the mother country and in case of war with the United States greatly

as the one to connect Truro with River du Loup and thus complete the Intercolonial Railway.

I understand three routes to have been under consideration of the Government if Canada; namely, one crossing the St. John River at Woodstock o Fredericton, the second in a more central direction through New Brunst ick and the third following the line selected by Major Robinson in 188.

The rov ; crossing the St. John River either at Woodstock or Fredericton is or e $w$ which the consent of Her Majesty's Government could not have been given.

The objections on military grounds to any line on the north side of the St. John River are insuperable. One of the main advantages sought in granting an imperial guarantee for constructing the railway would have been defeated, if that line had been selected.

The remaining lines were the central line and that following the general course of the route surveyed by Major Robinson - and Her Majesty's Government have learned with much satisfaction that the latter has been selected by the Canadian Government. The communication which this line affords with the Gulf of St. Lawrence at various points and its remoteness from the American border are conclusive considerations in its favor, and there can be no doubt that it is the only one which provides for the national objects involved in the undertaking.

I have, etc.

\section{(Signed) Buckingham and Chandos.}

To Governor, the RT. Hon. Viscount Monck.

1 The problem of routes produced an unusually large number of pamphlets of which there is a good collection in the Canadian archives at Ottawa. As early as 1849, Hon. Francis Hincks wrote: "I have treated this question on the assumption that the railway will be unproductive as a mercantile speculation." After quoting Major Robinson contra, he concludes that there is "sufficient doubt, however, to prevent the work being undertaken by any private company." Canada, its Financial Position and Resources, p. 19. 
increase the facility with which Canada could be defended. Nearly fifty years have elapsed since these reasons determined the location of the Intercolonial Railway, a period in which no wars have occurred involving Canada and the United States. The imperial forces have since been withdrawn. But the long succession of deficits ${ }^{1}$ which have accompanied the operation of the road are not all chargeable to Government ownership. They are eloquent of the futility of laying out a line on purely military considerations and then expecting it to pay as a commercial venture. ${ }^{2}$

The work of constructing the road was entered upon immediately after Confederation and the whole line was opened for traffic in $1876 .^{3}$ One hundred and twenty-six miles between Quebec and Rivière du Loup were acquired from the Grand Trunk in 1879.4 In 1899 the control of the Drummond County Railway gave it entrance to Montreal, its present western terminus. ${ }^{5}$ It has thus remained a maritime road, subject to water competition as well as to that of both the Grand Trunk and the Canadian Pacific, both of which have entered the Lower Provinces by more expeditious routes. In the carriage of through freight, it is quite unable, therefore, to exercise a controlling influence on rates except on the basis of larger deficits.

The completion of the Intercolonial Railway marks the close of the first era of railway construction in Canada. The activity of that period embraced the three colonies which in 1867 became the Dominion of Canada. Its outstanding events were the building of the Grand Trunk and

1 Deficits have occurred thirty-four times since its construction. Canada Year Book (1915), p. $469 \mathrm{ff}$.

2 Cp. Dunn, Journal of Political Economy, vol. xxiv, No. 6, p. 547. Biggar, Journal of Political Economy, vol. xxv, No. \&, p. 148.

${ }^{3}$ Canada Statistical Year Book (1895), p. 634.

4 The price was $\$ 1,500,000.42$ Vic., c. 11.

b This section cost $\$ 1,600,000$. 62-63 Vic., c. 6. See also agreement with the Grand Trunk. 62-63 Vic., c. 5. 
the Intercolonial roads, which together linked the colonies by lines of steel and gave Quebec and Ontario access to the sea through a Canadian port at all seasons. Of course, contemporaneous with this development, there was considerable labor expended upon the construction of short lines. Of these the most important certainly were the Great Western, already mentioned in connection with the Grand Trunk, and the Northern Railway, ${ }^{1}$ which proceeded from Toronto northwards and penetrated into the Georgian Bay district. In eastern Ontario a short line to the St. Lawrence gave Ottawa railway connections with the Grand Trunk and with American lines in New York State. ${ }^{2}$ As yet, however, it could scarcely be said that any part of Canada exhibited the full development of a railway net. There were some intersections in Ontario, but on the whole, while the warp had been laid, the woof was still lacking. Practically all the important towns had obtained rail connections, but these connections were pretty much to the nearest Lake port or a means of communication for import or export traffic. The gradual spread of areas intercommunicated, the filling-in of a network of lines in the industrial districts of Ontario and Quebec, must be understood to be taking place while public attention was focussed upon the problem of the construction of the Pacific Railway, the next important event in the history of Canadian transportation facilities.

112 Vic., c. 196 (1849); 22 Vic., c. 57 (1857).

2 13-14 Vic., c. 132 (1851); 14-15 Vic., c. 147 (1852); 16 Vic., cc. 52, 53 (1853); 18 Vic., c. 188 (1855). 


\section{CHAPTER III}

\section{THE ERA OF TRANSCONTINENTALS}

$\S 1$. The reason generally given for the building of the Pacific railway is that it was part of the agreement whereby British Columbia joined the Dominion. A similar superficial examination of causes explains the construction of the Intercolonial Railway on the basis of the Confederation compact. It has been shown, however, in regard to the latter that the Confederation agreement was rather the final step in the solution of a problem long in the minds of imperial and colonial statesmen. A somewhat analogous situation is revealed in the case of the Pacific Railway, which had been before the public as a desirable enterprise an even longer period than had the Intercolonial. It will not be forgotten that the great Champlain himself entered upon his western explorations with a view to discovering a short route to the Orient. This aspect of a Canadian transcontinental route came to the front again with the development of steam transportation. Prior even to Confederation various travelers and engineers canvassed the feasibility of such a highway. Naturally, as they treated the subject in a vague and imaginative way their writings did not lead to the actual construction of such a line, but they laid the foundation of an abiding belief ${ }^{1}$ that it was only a matter of time until Eastern and Western British North America should be united by a railroad. ${ }^{2}$ Finally a series of events, about to be recounted,

1 "I believe that many in this room will live to hear the whistle of the steam engine in the passes of the Rocky Mountains and to make the journey from Halifax to the Pacific in five or six days." Joseph Howe, speaking at Halifax, May 15, 1851.

2 The first application of a charter to construct a line to the Pacific was in 1851, but it was refused, as the time was not considered ripe for such an enterprise. See Journals of the Legislative Assembly (1851), vol. I. 
brought the project to earth and placed it in the arena of practical politics. Even more distinctly than in the preceding phases of policy dealt with, the first impulse to build such a line came from broad-based political considerations.

The first of these considerations concerns the winning of the American West. The very rapid expansion of the United States westward and northward, under the stimulus of railway construction, excited the alarm of Canadian statesmen. They feared that the United States planned to secure a large part of the Northwest country for itself. This fear was aggravated by boundary disputes, the significance of which did not always appear to be obvious to imperial statesmen. ${ }^{1}$ In the second place, at any rate, the fact was patent that the American "Granger" lines would carry off the trade of the Northwest territories to St. Paul, Minneapolis, and Chicago unless there was equally rapid development of rail facilities on the Canadian side of the boundary. Each of these reasons was a powerful inducement for Canadian statesmen to act. The New Brunswick boundary dispute had terminated unsatisfactorily for Canada with the loss of considerable territory. In the case of the Grand Trunk one of the reasons put forward for the inability of that road to capture more through traffic was the claim that it was practically impossible to do so once traffic had formed a given channel. Practical experience, as well as political, therefore, advised the immediate construction of lines into the Canadian West. Accordingly, we have measures taken the

1 In 1870 Sir John A. MacDonald wrote as follows to C. J. Brydges, of the Grand Trunk Railway: "Many thanks for your letter of the 26th giving me an account of your conversation with ... It is quite evident to me not only from this conversation, but from advices from Washington, that the United States Government are resolved to do all they can, short of war, to get possession of the Western territory and we must take immediate and vigorous steps to counteract them. One of the first things to be done is to show unmistakably our resolve to build the Pacific Railway." Pope, op. cit., vol. II, p. 161. 
final intent of which were to check American exploitation north of the forty-ninth parallel.

Immediately after Confederation the Dominion of Canada purchased the lands of the Hudson's Bay Company ${ }^{1}$ and established the Province of Manitoba. The first Northwest rebellion which followed this step drove home the necessity of a line of rail into the new territory. There was the danger at that time that the rebels would voluntarily call upon the United States to protect them; many reasons why such an appeal would not be made in vain; and finally the great military difficulties that the little force sent out from Eastern Canada to put down the rebellion had had to endure before it reached its destination. ${ }^{2}$ Beyond Manitoba lay the great plain that has since become the Provinces of Saskatchewan and Alberta, and while the danger appeared to be past in Manitoba there still existed to the west of it the possibility of an American wedge being thrust in between Canada and the Pacific.

Accordingly the entrance of British Columbia into the Canadian Confederation was the next step to be achieved. This was accomplished after negotiations. The inclusion of British Columbia in the sisterhood of Confederated Provinces not only rounded out and united the separate colonies of the British Crown, but really guaranteed to the Dominion her gateway to the West. ${ }^{3}$ The construction of a Pacific railway followed as a political as well as logical outcome. The railway, while affording physical and tangible evidence of the union that had been consummated, held the territories safe between Manitoba and the Rocky Mountains, opened up an immense terri-

1 The incorporation of the Northwest Territories Navigation and Railway Company was refused in 1851 because of difficulties arising out of the Hudson's Bay Company's rights.

2 Beckles Willson, The Life of Lord Strathcona and Mount Royal, vol. I, p. $432 \mathrm{ff}$.

3 Pope, op. cit., vol. II, p. 124. 
tory for colonization, and checked the drift of trade to American cities. Fundamentally, therefore, the inclusion of a provision in the British Columbia entrance agreement that a transcontinental line should be built rested upon the twofold basis of national unity and of commercial advantage. The forces which separately led to the building of the Grand Trunk and Intercolonial Railways were of sufficient power in this instance to launch and carry to completion Canada's first transcontinental line. Thus, amid the whirlpool of political controversy fundamentally Canada's railway policy shows singular consistency, exhibiting at once the influence of geographical situation and the force of national ambition.

$\S 2$. The history of the building of the Pacific Railway falls into two parts. The first period belongs to the deeade of $1870-80$ and is a record of the rivalry between competing contractors, of competing policies of construction, and of abortive attempts to carry the work forward. When the agreement with British Columbia was signed it included the proviso that the road was to be built within ten years. ${ }^{1}$ The inclusion of this time limit drew criticism from the Liberal Party, which was then in opposition. The Liberals held that it was likely to lay undue burdens on the Eastern Provinces in the way of taxes. ${ }^{2}$ They urged with considerable force that the financial resources of Eastern Canada were limited and that an enormous addition to the public debt was inadvisable. The Government, however, pressed forward with the scheme, and soon two rival companies were incorporated each with a view

1 Proclamation, Dominion Statutes (1872), CxxxII-Lxxxv.

2 The history of the various turns of policy are available in Hansard for the years $1871 \mathrm{ff}$. Valuable sidelights are to be obtained in the offcial Lives of Sir John A. MacDonald, Hon. Alexander Mackenzie, Lord Strathcona and Mount Royal, the Recollections of Sir Charles Tupper, and the Reminiscences of Sir Richard Cartwright. Readers of the latter will notice that the present writer differs in his view of Sir John MacDonald's motives in building the Canadian Pacific Railway and in regard to the entrance of British Columbia. 
to obtaining the contract for building the line. ${ }^{1}$ Hugh Allan, the wealthy head of the company owning the Allan Line of steamers, was the moving spirit behind one of these companies, the Canadian Pacific Railway, and in the election of 1872 he sought to buy his way into favor by placing large sums of money at the disposal of the Conservative Party. When this was exposed in Parliament it unhorsed the Government and brought to the head of affairs Alexander Mackenzie, leader of the Liberal Party.

In opposition the Liberals had supplemented their campaign of criticism of the transcontinental policy of the Conservatives with the alternative policy of a line constructed by piecemeal as the colonization of the Western prairies demanded. They suggested the building of a line from Manitoba westward. This was consonant to their view that the finances of Canada could not stand the expenditure necessary for at once laying down a road to the Pacific Coast. They had particularly objected to building a line through the difficult rocky country north of Lake Superior. Until such time as Canadian trade and finances warranted, as a party in power, the new Government now proposed to utilize the stretches of water lying between the Eastern and Western Provinces so as to give a combined water and rail system to the West and British Columbia. ${ }^{2}$ The policy met with little success. Negotiations with British Columbia to modify the agreement with respect to the time set for the completion of the line turned out badly. British Columbia sent her Premier to London to protest against delay. ${ }^{3}$ No company offered to undertake the building and operating of the line from Winnipeg to Lake Superior, one of the important links

1 The Canadian Pacific Railway, 35 Vic., c. 73; the Interoceanic Railway, 35 Vic., c. 72 (1872).

2 Mackenzie's address to the electors of Lambton in 1874.

Correspondence relating to the Canadian Pacific Railway. Official Returns. 
necessary for the utilization of the lake and rail route. ${ }^{1}$ In the end the Government had to place two hundred and twenty-seven miles under contract and proceed to its construction as a public work. The Pembina branch, south from Winnipeg, was begun also in 1876 and finished in 1878. This gave Winnipeg and Manitoba a railway outlet via St. Paul, and it was held by the Government, in deference to the exigencies of party politics, that this was a good reason why rapid construction of the complete Eastern line was not an imperative necessity. ${ }^{2}$ The six years of Liberal power left the project in this unsatisfactory position. For this fact the Government was not altogether to blame. Elements over which it had no control had conspired to hamper it in the execution of its policy.

On their return to power the Conservatives reaffirmed in a series of resolutions their original plan of building a line without delay from East to West. ${ }^{3}$ But the difficulty of the venture which had embarrassed the preceding Administration forced them for a short time to continue their predecessors' policy of Government construction. In the meantime efforts were being made to secure a company with the financial backing necessary to undertake a work of this magnitude. At length in December, 1880, after lengthy negotiations, the Government submitted to Parliament a contract with the Canadian Pacific Railway Company to build a road from Lake Nipissing to the Pacific Coast, the portion already constructed to be taken over as part of the system. The acceptance of this contract initiates the second period in the history of the

1 R. W. Scott in the Senate. Reported in the Dominion Register and Review (1879), p. 119.

2 "Now the route is thoroughly established and well patronized and the journey from Montreal to the capital of Manitoba via Chicago and St. Paul all rail may be made in four or five days." Mackenzie, speaking to his amendment giving the Liberal policy. Dominion Register and Review (1879), p. 120.

- May 10, 1879. 
Pacific Railway scheme. Sir John MacDonald had stated in 1872 that it was the intention of his Government to "be liberal" with the company. ${ }^{1}$ He kept his word, for the agreement ${ }^{2}$ provided for a money subsidy of $\$ 25,000,000$ and a land subsidy of $25,000,000$ acres. The latter grant, to be chosen from land in the West as far as possible, was to lie in alternative sections twenty-four miles deep, checker-board fashion, along the line of the road. The company was given the right to locate the line and its branches except for a number of terminal points. This privilege, valuable in the extreme because it permitted leconomic reasons in some degree to control the selection of a route, was interpreted broadly. Thus, as originally planned, the line was to run northwest to Edmonton, but, when the Kicking Horse Pass was discovered farther south, permission was given to take that route. ${ }^{3}$

An important clause of the agreement shut off competition from the United States. ${ }^{4}$ It was provided that for twenty years no line of railway should be permitted to be constructed in the Canadian West south of the Canadian Pacific Railway except under conditions that virtually meant that this territory was closed to all except to the Canadian Pacific. This was directly aimed at the Northern Pacific, which threatened to tap the country from the south, but also in a large way at all those lines present and prospective that Canadians feared would lure trade to the United States. Thus we have the old struggle for trade extended to the Western plains and revealing itself once more in legislative enactment.

[n many ways the line was made a favored one. Such privileges as freedom from taxation and the remission of customs duties on construction supplies indicated the

1 Writing to Sir John Rose, April 17, 1872. Pope, op. cit., vol. I, p. 189.

244 Vic., c. 1 (1881).

345 Vic., c. 53 (1882).

- "Except such lines as shall run s.w. or to the westward of s.w. nor within 15 miles of latitude $49 . "$ 
heavy price the Government had had to pay for putting through its policy. The only safeguard with respect to tolls was a provision that if profits exceed ten per cent of v the capital invested in the construction of the line, they might be reduced. With other features of the agreement we need not concern ourselves because they do not relate to the problems with which this study is concerned.)

When this agreement was presented to Parliament for ratification, it was discussed and confirmed on a strictly party basis, a procedure that meant it received a minimum of careful, disinterested criticism. Moreover, in this case the opposition were more than usually hampered in criticizing the terms of the bargain. Their avowed policy was that of piecemeal construction. Fundamentally this policy was based on the premise that a trunk line would not be a paying proposition for many years. Therefore, if the line promised to be a failure from the standpoint of pecuniary return, the opposition could hardly claim that the bargain, with its large grant of money and lands, was unduly generous to the company. Thus the Liberals, by reason of their main position, were really estopped from a very searching scrutiny into the economy of the plan. The weight of their attack fell upon the alleged need of immediate construction. ${ }^{1}$ They maintained that the cost of the road would place heavy burdens of taxation on Eastern Canada for which there would not be commensurate return because of the relative lack of development of the West. In the public press the Toronto Globe insisted that the concessions meant the creation of a huge railway and

1 "That the work should not unduly press on the taxation of the people, but be proceeded with in a manner which should not increase the existing rate of taxation. ... This is the keystone of the position." Hon. Edward Blake, December 14, 1880, in the House of Commons. In moving the postponement of work in British Columbia he said, earlier in the session, "but in the early days and for a long time the road will, I believe, be run at a loss." In later years he emphasized the monopoly aspect of the question: "If the Northwest wants anything it wants reasonable rates." February $5,1884$. 
land monopoly. ${ }^{1}$ This phase of the agreement received some notice in Parliament, but was secondary throughout to the question of the danger of additional taxation through undue haste in construction. ${ }^{2}$ As it was a party measure of a most contentious nature the opposition were unable to assist in shaping the legislation. Touching the dangers of monopoly the Government deemed the limitation of profits to ten per cent ample safeguard against oppressive rates.

The agreement having been confirmed by Parliament the construction of the road was undertaken with unprecedented vigor and the last spike was driven in the main line in 1885. The whole distance of 2906 miles was built five years before the contract called for its completion. The "liberal" terms, however, of Sir John MacDonald were not sufficient to finance the enterprise and the Canadian Pacific Railway came almost every year to Parliament as a suppliant for further assistance. ${ }^{3}$ As the fortunes of the Government were staked upon the success of the enterprise, the railway did not go away empty. History with grim sarcasm repeated the experience of Canada in connection with the Grand Trunk. According to the. Canada Statistical Year Book for 1895 the estimated cost of the Grand Trunk was $\$ 160,912,070$, the actual cost was $\$ 335,645,007$, the estimated cost of the Canadian Pacific Railway was $\$ 179,122,730$, the actual cost was $\$ 309,535,732.4$

The execution of the Canadian Pacific Railway Company's contract does not, of course, complete the history of that system. While constructing the main line its promoters were active in securing control of desirable con-

1 The Globe, December 13, 1880.

2 Cp. Hon. Wilfrid Laurier, December 21, 1880.

347 Vic., c. 1 (1884); 48 Vic., c. 57 (1885); 51 Vic., c. 32 (1888). By 51 Vic., c. 32 , the company accepted a bond guarantee of $\$ 15,000,000$ for the repeal of the clause shutting out competing lines.

- Canada Statistical Year Book (1895), p. 634. 
nections in Eastern Canada. In the plan of the Dominion Government the transcontinental line was to end at Lake Nipissing, to which point it was expected lines would build from Ontario and Quebec. ${ }^{1}$ In 1883 the Canadian Pacific Railway obtained extensions to Montreal and to Brockville. At the same time it leased the Ontario \& Quebec Railway, 582 miles long, which gave it access to Lake Huron and enabled it to tap western Ontario as far as St. Thomas. In 1885 the absorption of the North Shore Railway let it into Quebec, while the construction of an extension to the Ontario \& Quebec Railway from Smith's Falls to Montreal gave it a short line, independent of the Grand Trunk, from Toronto to that terminal. When the main line was completed in 1885 the total length of the Canadian Pacific Railway system was 4337.8 miles.

The period that followed was one of rapid development for the system at many points. In 1887 a short line from Montreal across a corner of the State of Maine to St. John, New Brunswick, was authorized. This gave the latter city the direct connections with Ontario and Quebec it had tried to obtain when the Intercolonial was laid out. In British Columbia the same year an extension from Port Moody to Vancouver was opened. In the United States arrangements with the St. Paul, Minneapolis \& Sault Ste. Marie and the Duluth, South Shore \& Atlantic Railways brought these important lines within the company's scope of influence. In 1890 a western Ontario extension was completed to Detroit. In the West the Regina \& Prince Albert line and the Calgary \& Edmonton line were leased. In 1907 a cut-off from Sudbury materially shortened the distance from Toronto to the West, while enabling the company to dispense with the use of the Grand Trunk to North Bay. Development and extension have continued unabated. A recent advance has been the

1 The statements regarding the growth of the Canadian Pacific Railway are based on the annual reports of the company. 
company's entrance into Nova Scotia. A direct line, roughly following the route originally planned, has been built from Winnipeg into the Edmonton district. The Crowsnest Pass Road enables it to enter Spokane and Portland, facilitating the handling of transcontinental freight.

In 1915 there was organized the Canadian Pacific Ocean Service Company to take over the ocean steamship business, including the famous Allan Line Steamship Company. In addition to the Allan Line fleet the company lowns ninety-one ocean, lake, and river steamers. The company also owns and operates seventeen hotels.

On December 31, 1916 the Canadian Pacific operated a mileage of 13,767.9 (1500.36 miles are double-tracked). To this must be added the mileage of the Minneapolis, St. Paul \& Sault Ste. Marie Railway, 4227.8, and of the Duluth, South Shore \& Atlantic Railway, 624.6, or a total effective control of 18,620.3 miles. The company's assets stand at $\$ 986,768,543.90$; of this amount $\$ 117,761,364.41$ are listed as inactive assets and include nearly $6,000,000$ acres of agricultural lands in the prairie Provinces, of which about 600,000 acres are irrigated lands. The average sale price of unirrigated land for the half-year ending December 31, 1916, was $\$ 15.18$ per acre; of irrigated land, $\$ 49.78$ per acre. Further, the company has large holdings in British Columbia, as well as valuable coal and timber lands, and natural gas and petroleum rights. Its share capital amounts to $\$ 340,681,921.12$, and it has a bonded debt of $\$ 231,934,882.10(\$ 52,000,000$ are in 6 per cent note certificates). ${ }^{1}$ The company early seized a commanding position among Canadian railroads, and the growth and prosperity of the Dominion, particularly of the West, has contributed greatly to its strength.

§3. The Canadian Pacific Railway is the only transcontinental line in Canada that may be said to be operat-

1 Report for the half-year ending December 31, 1916. 
ing on a normal basis. The Grand Trunk Pacific Railway, from Winnipeg to the Pacific Coast, and the National Transcontinental Railway from Winnipeg to Moncton, form a second line. Although designed to be operated by one company, both divisions are operated separately, the former by the Grand Trunk Pacific Railway Company, the latter by the Dominion Government. In the case of the Canadian Northern Railway, while in 1914 the mainline track was completed from Quebec to Port Mann, British Columbia, the whole has only recently come into operation. ${ }^{1}$ Financially both lines are in that condition, so familiar to the student of Canadian railways, which necessitates frequent recourse to Parliament for assistance. These lines, however, are already well intrenched in the West as traffic factors and are able to offer both through and combined water and rail accommodation to the East. This fact makes necessary their inclusion in the present sketch, although their history is short and incomplete.

The Grand Trunk Railway viewed with jealous surprise the rapid growth of the Canadian Pacific Railway, and when the latter began to encroach upon its Ontario territory met the advance with active hostility. Indeed, it is claimed that it was a "bear" movement in which Grand Trunk financiers were interested that so drove down the value of Canadian Pacific stock in 1883 that the Canadian Government was compelled to come to its protégé's rescue with guarantees that reassured investors. ${ }^{2}$ The opposition of the Grand Trunk, however, did not seriously retard the growth of the young and vigorous Canadian Pacific, and the older line was forced to witness the development of a powerful rival which competed with it in western Ontario territory and had an independent reserve of strength in an increasingly valuable traffic to the Northwest.

1 Since 1914.

Morgan's Annual Register, p. 112. C.P.R. circular to shareholders, December 29, 1883. 
The moral of the Canadian Pacific was lost neither upon the Grand Trunk, whose president of an earlier date had brushed aside ${ }^{1}$ overtures to build the Pacific road, nor upon Sir Wilfrid Laurier, whose party in the first instance had underestimated the possibilities of the West. When, therefore, the marvelously rapid development of Manitoba, Saskatchewan, and Alberta at the beginning of the last decade began to task the transportation facilities and the equipment of the Canadian Pacific Railway, the project of a second great transcontinental line was conceived. The scheme involved an agreement between the Grand Trunk Railway and the Dominion Government. Sir Wilfrid Laurier and his party went to the country on this issue in 1904, and once again the people of Canada sanctioned large expenditures for the construction of railways. The project was endorsed on the general argument that it would promote the development of the Northwest by furnishing additional railway facilities which would also be a line independent of the Canadian Pacific Railway. In many parts of the West there was considerable feeling that the Canadian Pacific was using its power to charge unduly high freight rates. Along with these considerations and more specifically it was urged that if this step were not taken, very much traffic would necessarily be lost to Canada by being carried on American lines. The following clause in the agreement, later confirmed, covers the whole point: -

It is hereby declared and agreed between the parties to this agreement that the aid herein provided for is granted by the Government of Canada for the express purpose of encouraging

1 "If you omit the clause providing for a line around the north shore of Lake Superior to Eastern Canada I shall be pleased to lay the matter before my board of directors. Otherwise they would throw it into the waste-paper basket."

"We must have a through line; I assured him in parting." Sir Charles Tupper's Recollections (an interview with Sir Henry Tyler, president of ;" the Grand Trunk), p. 139. 
the development of Canadian trade and the transportation of goods through Canadian channels. The company accepts the aid on these conditions and agrees that all freight originating on the line of the railway or its branches, not specifically routed otherwise by the shipper, shall, when destined for points in Canada, be carried entirely on Canadian territory, or between Canadian inland ports, and that the through rate on export traffic from the point of origin to the point of destination shall at no time be greater via Canadian ports than via United States ports, and that all such traffic not specifically routed otherwise by the shipper shall be carried to Canadian ocean ports.

The agreement ${ }^{1}$ provided that the road was to consist of two sections from Moncton, New Brunswick, to Winnipeg, 1800 miles, and from Winnipeg to the Pacific, 1756 miles. The eastern division, called the National Transcontinental Railway, was to be constructed by the Government of Canada, and leased for fifty years to the Grand Trunk Pacific for operation. The western division, the Grand Trunk Pacific, was to be built by that company under a bond guarantee of three quarters of the cost of construction. This was limited to a cost not exceeding $\$ 13,000$ per mile. Under an implement clause the Government agreed to make up the difference between the amount realized in certain bonds and their par value. In the case of the mountain division the Government further agreed to pay the bond interest for seven years. The Grand Trunk Pacific is controlled by the Grand Trunk Railway, so that the design was that ultimately the whole system should come under the control of that company.

The estimated cost of the undertaking has fallen far short of the actual expenditure that has been found necessary. ${ }^{2}$ The expenditure on the eastern division up to

13 Edw. VII (1903), c. 122.

2 Hon. W. S. Fielding stated on July 11, 1908, that the road would cost Canada $\$ 38,769,126$. Speech on the National Transcontinental Railway in the House of Commons. 
March 31, 1915, was $\$ 152,802,746$, while aid under the implement clause of the bond guarantee given in 1912 amounted to $\$ 4,994,417 .{ }^{1}$ The Grand Trunk Pacific is operating between Winnipeg and Prince Rupert 2228.91 miles. The eastern division, which was completed in November, 1913, has not, however, been taken over by the Grand Trunk Pacific, but is being operated by the Dominion Government. The future of the whole scheme at the present time remains to be determined. The strain of financing a Western line has proved to be too heavy for the Grand Trunk Railway, without even assuming the additional burden involved in .operating the eastern portion of the route while in its developmental stage. In December, 1915, Alfred W. Smithers, chairman of the Grand Trunk Railway Company, addressed a letter to the Prime Minister of Canada, suggesting that the Dominion Government should take over the Grand Trunk Pacific, "with all its branch lines, development company and other subsidiary companies, with all the assets, the Grand Trunk Railway Company to surrender to the Government the whole of the common stock of the Grand Trunk Pacific Railway Company on condition of the Government relieving the Grand Trunk Railway Company of all liabilities in respect of the Grand Trunk Pacific Railway Company," etc., and repaying to the Grand Trunk Railway Company any money advanced by the Grand Trunk Railway Company. The Dominion Government has taken steps to make a complete survey of the whole railway situation in Canada, but in the meantime, at the session of 1916, granted a loan of $\$ 8,000,000$ to assist the Grand Trunk Pacific.

\$ 4. The third transcontinental railroad, known as the Canadian Northern, began as an amalgamation to take over a couple of small Manitoba railways in $1898 .{ }^{2}$ Under the direction of two ambitious railroad builders, Messrs. . Canada Year Book (1915), p. 465 ff. 2 62-63 Vic., c. 57 (1900). j 
Mackenzie and Mann, the company leased several other short lines in Manitoba and formed the nucleus of a system. ${ }^{1}$ In 1902 power was obtained to build eastward toward Ottawa and Montreal, and westward, by Edmonton and the Skeena River, to the Pacific Coast. ${ }^{2}$ Thus, while the Grand Trunk Railway was maturing plans to build into the rich and rapidly developing agricultural areas of the West, the Canadian Northern Railway was planning to secure Eastern outlets. Although the logical outcome of this state of affairs should have been a fusion of these interests, unfortunately this did not take place. The Grand Trunk Railway, however, secured the financial support of the Canadian Government at the prica of agreeing, as we have seen, to a national Grand Transcontinental line to Canadian maritime ports. In spite of this the Canadian Northern did not relinquish its design to build eastward, though for ten years the history of the road largely centered around its feverish construction activity in the West. To a large degree excellence of roadbed and equipment was sacrificed in the determination to preëmpt rail facilities into new territory opening for settlement. As a result of this policy the company has over five thousand miles of line in operation in the prairie Provinces apart from its outlet to the head of navigation at Port Arthur on Lake Superior. In British Columbia it has pushed through the Rocky Mountains at Yellowhead Pass and has completed its line from that point to Vancouver.

In the meantime control was obtained of certain lines in Eastern Canada. This paved the way for building the connection link in the system between Montreal and Port Arthur, and in 1911 guarantees were secured from the Dominion Government for a bond issue that enabled this section of the line to be built. ${ }^{3}$ The present ${ }^{4}$ length of the
11 Edw. VII, c. 52 (1901).
2 \& Edw. VII, c. 50 (1902).
1-2 Geo. V, c. 6 .
- April 1, 1917. 
Canadian Northern Railway system is 9296 miles. Its system extends from Quebec to Vancouver, and taps Duluth, Toronto, Ottawa, and Montreal, covers the prairie Provinces with a large number of branches, and has the Halifax and Southwestern Railway in Nova Scotia. The company is so weak financially, however, that at recent sessions of Parliament it has had to secure further aid. In $1914^{1}$ a bond issue of $\$ 45,000,000$ at 4 per cent was guaranteed and at the session of 1916 it received a loan of $\$ 15,000,000$. Just as in the case of the Grand Trunk Pacific Railway, this loan has been made to meet urgent liabilities, while the Government is completing its survey of the whole Canadian railway problem. The companies comprising the Canadian Northern were recently consolidated into the Canadian Northern Railway System and the first annual report submitted for the year ending June 30,1915 , showed net earnings of $\$ 6,623,291.88$, against fixed charges of $\$ 8,263,574.99$, or a net loss or deficit of $\$ 1,640,283.11$; for the year ending June 30, 1916, net earnings, $\$ 9,373,530.54$; fixed charges, $\$ 9,621,657.70$; net loss or deficit, $\$ 248,127.16 .^{2}$

The difficulties of the financial situation arising out of the construction of the two later transcontinental lines, together with the traffic problems their presence in the competitive field entails, led the Dominion Government in July, 1916, to appoint a Royal Commission to inquire into railways and transportation in Canada. This Commission as originally named consisted of A. H. Smith, Sir H. L. Drayton, and Sir George Paish. Owing to illhealth Mr. Paish was unable to serve and W. M. Acworth was appointed in his place. The subject-matter of the reference to the commission is as follows: -

1. The general problem of transportation in Canada.

2. The status of each of the three transcontinental railway systems, that is to say, the Canadian Pacific Railway Sys-

14 Geo. V, c. 20.

2 Annual Reports, Canadian Northern Railway System. 
tem, the Grand Trunk Railway System (including the Grand Trunk Pacific Railway and the Grand Trunk Railway and their several branches) and the Canadian Northern Railway System, having special reference to the following considerations: -

(a) The territories served by each system and the service which it is capable of performing in the general scheme of transportation;

(b) Physical conditions, equipment and capacity for handling business;

(c) Methods of operation;

(d) Branch lines, feeders and connections in Canada;

(e) Connections in the United States;

(f) Steamship connections on both oceans;

(g) Capitalization, fixed charges and net earnings having regard to (1) present conditions, and (2) probable future development with increase of population.

3. The reorganization of any of the said railway systems, or the acquisition thereof by the State; and in the latter case the most effective system of operation, whether in connection with the Intercolonial Railway or otherwise.

4. Generally speaking, all matters which the members of the Board may consider pertinent or relevant to the general scope of the Inquiry.

At time of writing ${ }^{1}$ the Commission has not reported, but it is evident that Canada is on the verge of a new period in the history of her transportation policy. Judging from the past we may expect that amid considerable controversy and difference of point of view the solution finally adopted will lie along national rather than strictly economic lines.

1 April 1, 1917. 


\section{CHAPTER IV}

\section{RESULTS OF THE CANADIAN TRANSPORTATION POLICY}

$\S 1$. IN the preceding chapters we have traced the rise and progress of systems of transportation in Canada. We have seen that the Canadian Government's policy from the beginning, of extending aid and encouragement, has been a most important factor in their development. With the exception of the Canadian Northern Railway, which has recently received assistance from the Government, and now has the status of an adopted child in the family, the transportation systems of Canada have come into existence not only under the protective ægis of the Government, but with its active help. If there is one thing clear in the history of transportation in Canada, it is that the people of Canada, through their Parliamentary representatives, have stood behind every large transportation scheme that has succeeded in establishing itself. And it is undoubtedly true that if this had not been the fact the Grand Trunk Railway Company's transcontinental project would have been less expensive in execution, more modest in scope, and more gradual in realization. With respect to the Canadian Northern, while it did not receive in the same striking manner the support of the Federal Government, it is no less true that if it had not been granted generous financial assistance from both the Federal and from five Provincial Governments, ${ }^{1}$ its plans for a transcontinental line would not have been carried out so rapidly.

1 Sessional Paper No. 282a, Financial Statements of the Canadian Northern Railway System (April 15, 1916), p. 5. 
The aftermath of this railroad building is now at hand. As has been indicated, grave financial difficulties face both the Grand Trunk Pacific Railway Company and the Canadian Northern Railway System. The latest step of the Dominion Government, as we have seen, has been the appointment of a Royal Commission of Enquiry into the Canadian railway situation with a view to a final solution of the pressing problems now demanding attention. If the analysis of causes in the preceding pages is correct, this active interest, both in the past and at present, has been and is due principally to national considerations. It has been shown to have had several phases; an attempt to capture traffic flowing eastward from the Middle Western States, a system of railways for military purposes in case of American invasion, the preëmption of Western territory lest it be won by the United States, the retention of Western Canadian traffic to Canadian trade channels - in these terms the causes of governmental assistance to transportation development must be given.

This conclusion does not deny the influence of purely economic forces. They were a factor and an important factor in the situation, but the point is, purely economic forces were not dominant and controlling. In the case of all these enterprises, except the Rideau Canal and the Intercolonial Railway, there was a lively appreciation of economic advantages to accrue to Canada, but the active assistance of the Government is to be explained only on the basis of the fact that purely economic considerations would not be sufficient to build the desired lines at the time nor in the direction that national interests required. Roads, due to economic forces, were being built, but they threatened to divert the traffic to American ports and to American cities. The feeling of nationality that this danger aroused had its answer in the Canadian roads, built to protect the integrity of Canada by protecting Canadian trade and commerce. In this degree and in this way the 
economic factor has entered into the situation. It has been a considerable force in moulding national policy. But in both the earlier and later eras of transportation development in Canada, the economic factor has been lifted up and transmuted into terms of national power and selfsufficiency. Transportation policy has not been viewed merely from the standpoint of commercial and economic convenience. In the final outcome these national ideas have dictated the course of development.

It remains now to consider the salient characteristics of the transportation facilities of Canada viewed as a whole. A survey of the field reveals two closely woven networks of lines. The development of a railroad net in the East, in close conjunction with waterways, has already been referred to. The industrial growth of Ontario has continued the process. Out of 35,582 miles of railway lines in Canada in 1914, 10,702 were located in Ontario. ${ }^{1}$ In the Northwest the competition between the three transcontinental systems for territory and the absolute reliance of the country upon railway service ${ }^{2}$ have resulted in the development of a net spread over 300,000 square miles. In 1915 the Provinces of Manitoba, Saskatchewan, and Alberta contained 12,999 miles. ${ }^{3}$ While much of this mileage has been built by the transcontinental companies in the development of their branch lines, the pressing necessity for roads led to the construction of a number of independent short lines. As in the Eastern Provinces the history of these roads may be epitomized in a sentence: they were promoted and built to satisfy local interests and afterwards absorbed by the transcontinental lines in their struggle for territory. As a result of this, while all available territory where traffic is likely to develop has not been exploited, still the three great lines touch practically every

1 Canada Year Book (1915), p. 467.

${ }^{2}$ A certain amount of logs is floated down the rivers for lumber, but boat service has practically passed out of existence within this area.

${ }^{3}$ Canada Year Book (1915), p. 467. 
important point. They cross and intercross each other at many places.

The Western expansion in shape resembles a partly opened fan. The outer points, not far from the foothills of the Rocky Mountains, are Macleod, Calgary, Edmonton, and Athabasca Landing. Almost in a line in the midwest are Regina, Saskatoon, and Prince Albert. Still farther east are Brandon and Dauphin. Finally all lines converge on Winnipeg, the end of the handle. Unlike the Eastern net, in the West there are no complications produced by waterways. The development of the country is bound up wholly with the policy of the railroads.

Of great importance in the rate situation is the absence of traffic-producing territory between Fort William and 'Sudbury. Between the Northwest and the East - that is, between the great agricultural and manufacturing centers of the Dominion - lies a vast, undeveloped area north of Lake Superior. Canada has no "middle States." Instead of East becoming West by insensible gradations, through territory rich in traffic, there is a great expanse, which must be traversed, of difficult country, with climatic extremes and with practically no traffic. The country is rocky and wild. It has been burnt over, and is now covered by a slight growth of scrub, too small and too stunted for market purposes. Time may change this condition of affairs, but at present this region furnishes practically no traffic. On the Grand Trunk Pacific line, farther north than on the Canadian Pacific or Canadian Northern, a considerable clay belt is reported. In time this will probably make a good agricultural district. But here, too, though with more promise, railway traffic is a hope of the future. This part of the transcontinental routes necessarily increases the proportion of indirect costs, for while the lines must be maintained as essential links in the respective systems, they do not contribute their due share of the revenue. The great significance of this feature of 
the transportation systems of Canada has repeatedly appeared in connection with a number of Western rate cases.

Another marked feature of Canadian railway territory is that it is over three thousand miles in length, but relaftively is very narrow. ${ }^{1}$ The distance from Macleod to Athabasca Landing is 397 miles. A glance at the map will show that this measures roughly the breadth of the railroad area on the plains. ${ }^{2}$ In the East the distance from Toronto to Cochrane, quite the greatest north-to-south distance, is 480 miles, and the traffic strip continues to narrow until it bends southward to the Maritime Provinces. As a consequence there are no independent cross-lines of importance in Canada. The great traffic route is east and west. The gateway cities of Canada are not distinctively on the American border with their own transportation lines leading therefrom into the interior. The gateway cities of Canada in the main are at convenient points of transshipment along the East and West routes, and their proximity to the American boundary is largely a matter of accident. Of course, it is possible that the development of the Hudson's Bay route may change decisively the situation, or the removal of tariff disabilities enable the American lines to compete more effectively, but at present the three transcontinentals control the Canadian rail transportation situation from Vancouver to Halifax. The combined length of these three lines is approximately over ninety per cent of the whole railroad mileage in the Dominion and their activity in construction has been continually increasing the proportion. ${ }^{3}$ In one respect, how-

1 The figures given for the various distances mentioned are taken from the official statements of the various companies.

2 The Edmonton-Dunvegan and British Columbia Railway is building from Edmonton to Dunvegan and Peace River Landing on the Peace River, approximately a hundred miles farther north than Athabasca Landing.

${ }^{3}$ Between January 1, 1900, and April 1, 1909, of 117 charters granted, 26 lapsed, and only 455.5 miles were built independently of the trunk lines. 
ever, the transcontinental lines have not complete control over the East and West traffic situation. The system of waterways from tidewater to Fort William, built up as we have seen to serve another purpose, justifies itself to a large degree through its influence upon East and West traffic. Nor must the influence of this factor in the case of purely Eastern traffic be forgotten. Here it is sufficient to note that the narrowness of the traffic-producing strip enables it to exert its maximum effect.

The most striking feature, however, in the transcontinental situation is the solidly established position of the Canadian Pacific Railway. Well equipped, substantially built, well located for through traffic, with valuable routes and considerable financial strength, the Canadian Pacific Railway dominates the Western freight situation. ${ }^{1}$ That primacy may not be of long continuance, for, although the Grand Trunk Pacific and the Canadian Northern lack the Canadian Pacific's strength and equipment, they are able to compete now for Western traffic. The real struggle between systems lies in the future. This holds true even though financial difficulties may force considerable modification in the organization of the Grand Trunk Pacific Railway Company and of the Canadian Northern Railway System. The financial organization may change, but the location of the lines and physical equipment will scarcely be relinquished or changed except for the better. At present the older road is in the favored position, but the great possibilities locked up in the development of the wide expanse of territory served by the other lines does not mean that this will necessarily continue to be the case.

The outstanding characteristics of Canadian traffic conditions appear to be the presence of two well-defined traffic centers, one in the East and the other in the West,

1 The Canadian Pacific carries considerable through freight from Eastern American points to Western American points. This traffic, however, does not enter into the question of rate-making in Canada. 
separated by an immense undeveloped area, a large part of which probably never will be valuable as a source of freight. To this must be added waterway competition to an exceptional extent; the absence of independent crossroads; intimate international relationships; an extremely long, narrow field of traffic operations; and the centralization of facilities in three companies, of which one at the present time occupies the position of dominance.

$\S 2$. These features suggest a rate structure of considerable complexity. The conditions of traffic must be adjusted to the extent of the territory with its diversity of agricultural and industrial pursuits. On the other hand, the control of traffic by a few companies is an element in favor of simplicity and uniformity of classification. The system as built up is comparatively simple in this latter respect. One classification system holds for all items of freight movement in Canada, except in the case of goods entering the Yukon district and in the case of a few goods which for one reason or another follow American classification. The various articles of freight fall regularly into ten numbered classes. Added to this above first class there is a progression of six classes, viz., $1 \frac{1}{2}, \mathrm{D}-1$ (doublefirst class), $2 \frac{1}{2}-1,3-1,3 \frac{1}{2}-1$, and 4-1. There are thus sixteen classes in all. This system of classification is known as the "Canadian Classification" and is issued by the Canadian Freight Association, which represents railroads operating in Canada. The present issue of the Canadian Classification contains approximately seven thousand items.

It must be noted that uniform classification of articles of freight movement does not mean that a commodity classified in a given class will be charged the same rate for carriage a given distance in any part of Canada. The charge for carriage would be a question of rates. This is one of classification. Rates in different parts of Canada are not uniform. Mileage rates vary in different parts of 
the country. But classification is uniform. The same I article will be put in the same class in any part of the Canadian Classification territory, while the rate charged will rest upon the tariffs determined upon for that particular part of the country.

Canada is divided into five rate territories, and in each of these five territories certain rates are fixed for the carriage of the traffic specified in the sixteen classes of the Canadian Classification. These rate territories together cover the whole traffic area of Canada from coast to coast. Naming them in order they are: (1) Atlantic territory, which includes all territory from the Atlantic westward as far as Sudbury, just north of Georgian Bay; (2) Superior territory from Sudbury to Port Arthur; (3) Prairie territory, from all points in New Ontario (i.e., in Ontario west of and including Port Arthur), Manitoba, Saskatchewan, Alberta north to Athabasca Landing and west to points just east of the Rocky Mountains; (4) Pacific territory from the western termini of Prairie territory to the Pacific Coast; (5) British Columbia Lakes territory which covers local traffic carried on vessels owned by the railway companies between ports of call on the Arrow, Slocan, Kootenay, Trout, and Okanagan Lakes and the Columbia River. The rates for each territory are fixed upon the basis of the peculiar conditions of the traffic therein existing.

The above statement should make clear the fact that while there is a uniform classification there is not a uniform basis of rates. There is further to be noted the fact that the interrelationship between rates differs in Western Canada from that in the East. In Eastern Canada the fifth class is the pivot around which the rate structure is built. The other class rates are percentages above or below fifth class. For instance, class one is 100 per cent higher than fifth class; class 2,75 per cent; class 3,50 per cent; class 4, 25 per cent. A change, therefore, in class five affects the whole range of standard traffic in Eastern 
territory. In the West (for Prairie, Pacific, and British Columbia Lakes territory) the first class is the basic rate, the fourth class is 50 per cent less, while the other classes carry no fixed percentage - but are adjusted with a view to the best meeting of the demands of the traffic. The variations in interclass relationships touch chiefly the fourth, sixth, and tenth classes. These classes are relatively lower under the Western method of building up the rate structure than they would be under the Eastern. They affect particularly many commodities shipped in bulk; agricultural implements, and such necessaries as lumber, coal, cement, and building material. Practically all of these classes of freight move in Western Canada in car lots.

$\checkmark$ Within the rate territories the standard tariffs are built upon a mileage basis. The distances are graduated into zones of 5 miles up to 100 miles, 10 miles from 100 miles to 500 miles, 25 miles from 500 miles to 1500 miles, and on 50-mile zones thereafter. The whole thus presents a system of tapering rates.

i In general these standard rates are higher in the West than in the East. The highest rates fixed by standard tariffs naturally occur in Pacific territory, which includes those portions of the lines that cross the Rockies. A high level also exists in Superior territory from Sudbury to Fort William. The interrelationship between classes also shows slight deviations here. As a matter of fact, the rates of this division of the field are of slight importance because of the absence of traffic. They are really paper rates. British Columbia boats have the same rates as Prairie territory computed from port to port on the shortest water mileage. The highest rates of all are into the Yukon. These go on Northern classification. The conditions are exceptional, the traffic is very light and is a very small fraction of the whole freight movement. The mere mention of it sufficiently indicates its importance. 
For shipments into the United States or for export it has been found convenient in Eastern Canada to use the official classification. For the same reason freight moves from Central Freight Association territory in the United States into Canada on the Canadian Classification with a compromise scale of rates. Freight from the New York group moves on a percentage of the New York-Chicago westbound rate into the western Ontario peninsula. For instance, freight from New York to London, Ontario, pays on the basis of $\mathbf{7 6}$ per cent of the rate on the same goods to Chicago.

This describes briefly the general standard rate structure of the Dominion of Canada. It remains, however, to be pointed out that a large part of the traffic moves under other tariffs and conditions. The standard rate structure serves only as a point of departure. Modifying it is an elaborate complex of commodity tariffs, arbitraries, differentials, and "town" and "class" tariffs which serve to meet special traffic conditions, due to competition, the nature of the commodities, or the demands of trade. These modifications show that after all the Canadian rate structure is an intricate and flexible adjustment to the requirements of freight movement.

This appears particularly with respect to the demands of competing distributive centers. In Prairie and inland Pacific territory the problem has been solved by the development of a system of "town tariffs." These town tariffs grant a fifteen per cent abatement of the standard rate from all "recognized distributive centers." They are restricted to these "centers" and their effect is to tend to give each city and town its "natural" distributive territory. These tariffs cover the case of distributive shipments outwards. The problem of importation by wholesalers and jobbers has been met in another way. The Board of Railway Commissioners, as a result of investigations and complaints, has fixed rates to these points from 
Lake Superior and Pacific termini. In a sense, similar in nature though more general in character, are "special class rates" established from the same termini into Prairie territory. These grant lower rates than those set forth in the standard tariff, but they are not determined on a percentage basis. Their main service is with regard to shipment by lake and rail via Port Arthur and Fort William to the West. These rates are available for any shipper who wishes to ship directly from the East.

"Natural distributive center" is a vague and expansive phrase which has not been closely defined. There has scarcely been need for such. The interlacing of the three transcontinental lines in the Prairie Provinces has resulted in so many "centers" that smaller towns lacking service from two lines can hardly hope to become serious competitors for distributive business. The Western traffic manager's point of view may be seen in the statement that "a cigar factory in a little town would not make a natural distributive center." The general effect of the present rate structure is to build up a number of recognized centers which have the distributive business of the West pretty well under control.

In the East the situation is somewhat different. Here water competition, the presence of a number of large and long-established competing centers, and considerations arising out of international trade, have not made feasible the granting of flat reductions below the standard tariff. Instead there has grown up a system of interrelated rates which seeks nicely to balance the conflicting claims of competing cities. The two leading cities of Canada, Montreal, and Toronto, are the key-points. Rates to other centers are built up with regard to the rates to these two cities. In the East the cities of Sherbrooke and Quebec take arbitraries on the Montreal rate. Windsor and other points in western Ontario have their rates governed fundamentally by the New York-Detroit rate through the 
medium of the latter's influence upon the Montreal-Detroit rate.

The rates to the Maritime Provinces are fixed on the basis of the New York rate and the Boston route; that is, the rate that Boston takes over New York, plus port charges, insurance, and vessel rate charges to St. John, Halifax, Truro, Sidney, and other ports, determine the rail rates to these points. The Maritime Provinces get the benefit of this alternative route. Freight to the Canadian West from Halifax, Sidney, and other Maritime Province cities can travel via Boston over American lines or by Quebec or Montreal over Canadian railways. Waterway transport to the head of Lake Superior during the summer months provides a couple of combined routes to western Canada, either by Duluth and American lines or by Fort William or Port Arthur and Canadian lines.

To points on the Pacific slope the basal rate from the East is the Montreal-Vancouver rate. This rate in the first instance is based on the New York-Chicago rate and the Chicago-Seattle rate plus the rate from Seattle to Vancouver. This in turn is governed by water competition via the Panama Canal. Previous to the existence of the Canal the rate was based on the water rate around Cape Horn. Traffic also moved within this rate by a combined water and rail route via the Isthmus. For through traffic rates from the East to Vancouver, Toronto, Ottawa, and Montreal territory are blanketed, and vice versa. In this case during the navigation season the water and rail rate compared to the all-rail rate is lower by 10 cents per hundredweight, on the first class, 8 cents less on the second class, 7 cents on the third, 6 cents on the fourth, and 5 cents less on the remaining classes.

These various modifications on the standard tariffs relate to classes of goods. They particularly represent concessions or adaptations of a general nature to territorial conditions. In some instances they are due to the efforts 
of particular communities to put themselves in a more advantageous trading position. But in most cases they arise from the natural circumstances of location and have been made by the railways themselves on their own initiative in the pursuit of traffic. They represent, therefore, one phase of the principle of charging what the traffic will bear.

This principle receives more striking exemplification in connection with commodity rates under which a great part of the freight movement takes place. In Canada, as elsewhere, the presence of a commodity rate simply means that the traffic will not move freely at the rate reckoned on the basis of the standard or general tariffs. Commodity rates are then used. They are merely lower rates designed to take care of large quantities of particular commodities moving under special conditions. There are a great many of these in Canada. The total number of freight schedules filed by the railways with the chief traffic officer of the Board of Railway Commissioners from November 1, 1904, up to and including March 31, 1915, was 427,675. Not all of these, of course, were commodity tariffs, town and general tariffs are included in the total, but in the main these tariffs referred to a particular commodity on which a special rate had been made between two points. For the year ending March 31, 1916, the number of freight tariffs including supplements filed were 52,671. These numbers show to what a large degree the real rate structure of Canada has been built up, in this gradual piecemeal fashion, in response to the demands of trade. It is "scarcely necessary to point out again that the Canadian Classification and standard tariffs are but a point of departure.

The operation of these commodity tariffs may be exhibited in a few typical cases. These cases are drawn from the tariffs on staple commodities and they are sufficient to illustrate the influence of commodity tariffs on the gen- 
eral rate situation. For instance, coal is an important commodity in universal use, but especially important in the industrial part of Eastern Canada. The coal supplies of Canada are not adjacent to the manufacturing area. There is coal in the Maritime Provinces, coal in the Prairie Provinces and in British Columbia. With respect to Ontario the only possible Canadian supply that might be tapped is that in the Maritime Provinces. But it is obvious that the distance is almost prohibitive. On the other hand, the coal areas of the United States afford a convenient supply. Hence we find coal moving on special tariffs as far north as Sudbury. In western Ontario the great bulk of the traffic is received from the Niagara frontier and Black Rock, New York. Bituminous coal also enters via Detroit. The west-of-Toronto territory is subdivided into eight groups, rates ranging from 40 cents per ton in the Welland Canal district to $\$ 1.20$ per ton in the Lake Huron and Georgian Bay district. North and east of Toronto there are fifty groups which are partly served from the Niagara frontier. Farther east an intricate situation presents itself. The gateways are more numerous. Between Coburg and Montreal, inclusive, there are eighteen coal routes into the manufacturing area. The two dominating proportional tariffs are those of the Canadian Pacific Railway from Prescott because of the short mileage to Ottawa and the Ottawa Valley and of the Grand Trunk Railway from Rouse's Point. The proportionals from other Quebec gateways appear to be predicated on those from Rouse's Point. The evident purpose of commodity tariffs here is larger than that of securing the coal traffic alone. Coal is an important element in manufacturing; and a cheap supply means an increase of traffic in other lines of goods. A low level of fuel cost may mean the presence or absence of a certain industrial enterprise on a given line of railroad.

In prairie territory the coal centers are in the Souris 
Valley, near Lethbridge, and the Drumheller and Edmonton districts. From these points coal moves on tapering mileage tariffs. It is of interest to note here that the Souris coal fields encounter competition from the Eastern American coal mines, because of a low commodity rate from the head of the Lakes. This low rate is to be explained by the fact that coal makes a valuable back haul for the railroads and Lake carriers and tends to balance the tremendous freight movement in grain to the Lake ports.

Elsewhere in Canada coal receives similar treatment. On the Pacific Coast it moves inland on special commodity mileage tariffs, finally meeting on a similar tariff the coal from Lethbridge district. In the Maritime Provinces low rates to most points are compelled by water competition. Water carriage of Nova Scotia coal, indeed, permits it to move west to Montreal, where it meets American coal entering via the Prescott, Rouse's Point, and other gateways.

After coal we may note the case of grain. Grain rates to the head of the Lakes have a very low fixed commodity rate. This is due not only to the importance of the traffic, but also to legislative agreements with the grain-carrying lines entered into by the Dominion and Manitoba Governments. When the railways were seeking concessions from these Governments in the West, this was one form that the quid pro quo took.

The movement of grain from the Lake receiving ports eastward is of interest also because it shows the efforts made by the railways to coöperate with trade and industry. There are three rates to the East: all rail, and exwater rates for grain for domestic purposes, and the rate on grain for export. The basal rate in the case is the rate from Fort William to Montreal. But this rate, in turn, is related to the Chicago-New York rate because of the competition for grain carriage via Chicago and New York and via the Canadian route. To go back one step farther, the original Chicago-New York rate derives from a rate based 
on water competition via the Great Lakes and the Erie Canal. This is a good instance of the relationship of commodity rates in Canada to those over which no Canadian regulative board could exercise control, except by lowering the Canadian rates to compete for American trade.

The ex-water rates on grain carriage from the different Lake and river ports receiving grain is made proportional to the straight Fort William-Montreal rate. This takes care of the Eastern situation and enables ports like Kingston, at the foot of Lake Ontario, to share in the grain trade. Another phase of the grain rates has to do with grain for export being manufactured in transit. Milling in transit is permitted. For a nominal charge grain from Fort William on stopover privileges can be milled at Ontario or Quebec points. The product is reshipped on the basis of the through rate. Little need be said of the allrail rate from the West to the ocean ports. In the winter of 1916 the congestion of grain in the West led to measures being taken to secure a low enough rate to cause grain to move by rail to the ocean terminals, but the scheme has not as yet worked out with any degree of success. ${ }^{1}$

Coal and grain are important commodities and the treatment they receive in the matter of rates is typical of that given to a large number of staple commodities. For instance, lumber, an important product in the northern part of Ontario and of Quebec, moves under an elaborate commodity tariff to the main centers of demand. There are especially low rates in the Ottawa Valley on account of water competition. In the West lumber moves under straight commodity mileage rates. The sources of supply in this case are rather widely distributed, but a great deal comes from the mills in British Columbia. Competition between British Columbia and Ontario and Quebec sugar refiners has resulted in a number of struggles

1 See, however, Annual Report of the Council of the Quebec Board of Trade, year ending January 31, 1917, p. 7. 
over rates for that commodity. The present rates fix the meeting-point between the Eastern and Western refiners in central Manitoba. As a result the Western refiners supply most of the demand in prairie territory. Barbed wire travels eastward from Toronto and westward from Montreal on the same basis of rates. Oil moves from Petrolia, Ontario, on a 66-cent all-rail rate to Winnipeg, where it competes with the products of the Kansas oil fields as well as with oil from Eastern American oil fields moving on a combined water and rail rate via Fort William. In the fruit districts of Ontario concentration points are named for fruits. At these points the fruit is loaded in bulk and then receives the through commodity rate from the initial point of shipment.

Much of the large traffic between points in the United States and Canada moves on special commodity rates arranged by the lines affected. Where arrangements of this sort are not voluntarily made, the general rule for freight between the two countries is to regard it as a joint rate and therefore lower than the sum of the local rates. As we have already noted, between the Eastern railway net in Canada and the adjoining territory in the United States, goods are shipped into the United States on the American Classification and into Canada on the Canadian Classification.

The salient characteristics of the Canadian rate structure are: (1) a uniform Canadian Classification for all of Canada except for the Yukon; (2) different rate levels corresponding in a general way with the different kind of traffic conditions found in different parts of the Dominion; (3) town and special class tariffs to protect the distributive centers; and (4) a great mass of commodity tariffs to meet the peculiar demands of commerce and industry.

The importance of this structure to the work of the Board of Railway Commissioners lies in the fact that it is one of considerable intricacy that has grown up gradually 
to meet the demands of the Canadian situation. Any drastic change in rates must call into consideration a large number of factors, not always on the surface. Disputes cannot be settled with regard solely to the particular case under review. Thus a change in rates on grain being carried between a Lake port and an inland milling center cannot rest merely on its unfairness or fairness per se. It really places in issue the whole structure of grain rates. This in turn is interlinked with the American rate structure.

Another consideration is that the wide deviations from the formal regularity of the standard tariffs in themselves demonstrate the difficulty, not to say impossibility, of laying down any general standard. Thus the general standards, voluntarily established by the railroads themselves, have been radically modified by positive influences largely outside of the control of the railroads as a group or as individual systems. It is difficult to discover how a railway commission could ignore these natural circumstances or by fiat hope to bring them under standardized practice.

§3. These facts suggest a rather contracted field for the effective operation of a railroad commission with jurisdiction over rates, no matter how plenary the powers that may have been conferred upon it. The presence of waterway competition at many important points brings to bear a natural corrective upon rates, while injecting an element into the situation difficult to meet by administrative ruling, though it is true such rulings might be applied to water routes also. Equally difficult to modify are the conditions produced by the international relationships of both the Grand Trunk and the Canadian Pacific. Both have extensive American divisions over which a Canadian board can have no control. Moreover, all of the lines have to face, to some degree, conditions of competition created by rival American lines. That which is a disturbing element in certain sections in the United States naturally assumes 
greater relative importance in the long, narrow Canadian field.

Limitation upon the powers of a commission arise in these two instances from the nature of the obstacles. A number of factors conspire not to limit the power of the commission, but to simplify its problems. As a result of centralization of railway control in any given situation scarcely more than three or four lines will be directly concerned, and as each taps practically all the important centers of originating traffic, there is little likelihood of any single line allying itself with interregional rivalry. The gap between East and West simplifies a rate commission's problems tơ this degree: there isno great series of middle Canadian manufacturing and distributing centers competing with cities farther East for the trade of the West. It thus escapes the necessity of passing upon a great variety of rate adjustments. From Winnipeg westward the situation undoubtedly is pregnant with greater possibilities of controversy. Winnipeg stands somewhat in the same way to the Canadian prairies as Chicago or St. Louis to the American Granger States. In Canada, however, there is only one city in the field with a corresponding simplification in problem and scope of influence. But beyond Winnipeg are the cities of Brandon, Regina, Moosejaw, Saskatoon, North Battleford, Prince Albert, Edmonton, and Calgary. As these cities grow and proceed to claim and develop more carefully their distribution fields, we may expect decisions of far-reaching and important consequence, not only to themselves but to the cities of the East and of the Pacific Coast. On the whole, however,' the natural features of the Canadian situation tend to reduce the power of a regulative commission to fairly narrow limits.

Controlling a railway commission's policy must be the fundamental principle of the relationship of property to income as affected by rate determinations. This settled, 


\section{RESULTS OF TRANSPORTATION POLICY}

there remains the secondary problem as to how the chosen policy will be effectuated. Two courses are possible: to accept the developed structure and modify rates to bring them into harmony with the policy settled upon, or to remodel the whole on the basis of a general theory of rate-making. The study of the decisions of the Board of Railway Commissioners of Canada, which follows a survey of the evolution of means of public control, will show how this body has evolved its fundamental principle and the course it has pursued with regard to the development of rates and rate structure. 


\section{CHAPTER V}

\section{THE MACHINERY OF PUBLIC CONTROL OVER}

RATES

$\S 1$. ThE present chapter will be devoted to an account of the growth of means of public control over railroad enterprises in Canada. Preceding chapters have traced the evolution of means of transportation in Canada from the date when the British colonies in North America began a calculated policy to build up convenient and self-sufficient avenues for the carriage of goods. This policy, continued without serious deviation or lapse for nearly a century, as we have shown, has given the Dominion of Canada a generous endowment of navigable waterways and railway lines. Despite comparative sparseness of population, "magnificent distances," great engineering difficulties, there has been developed a comprehensive system of transportation that enables traffic to move from one end of the Dominion to the other and allows Canadian products to find access to the markets of the world. It is not to be imagined that these immense enterprises, carried through at great cost, have not had their influence upon law and legislation. The increasing complexity of economic life combined with the growth in importance of the transport function united to develop in Canada as elsewhere problems and evils which simple methods were unfitted to control. Hence, just as the growth of transportation facilities represents an evolution and progression, so does the means of the State to insure that they serve their due purpose become more complex with the corresponding increasing complexity of the problems raised.

In the development of means of control the process has 
been one of accretion or addition rather than that of replacement and repeal. New devices, of necessity, were created and superimposed upon existent regulations. Thus, to-day in Canada there are four ways by which railroads come under the power of the State. These four ways are: (1) by the common law; (2) by restrictions imposed upon the company in its charter when incorporated; (3) by statutory regulations of a general nature; and (4) by a railway commission with comprehensive powers of supervision and correction. Each of these means represents an advance upon those preceding. In certain particulars there might be some limitation upon the scope of former means, but in the main each method has been retained and is relied upon for the achievement of certain ends. As the central interest of this study is in the rate determinations of the Board of Railway Commissioners, it is obviously to the best advantage here to confine attention largely to the development of that aspect of public control. A brief survey will be made of the progress of rate regulation between 1835 and the present time in Canada. Other aspects of State control will be largely ignored, except to indicate in regard to the Board of Railway Commissioners the relative importance of the rate-determining function to others with which it is charged. It may be noted here that the problem of the regulation of rates in the case of navigation has not been touched except in connection with combined water and rail rates or where navigation lines are owned by the railroads. Provincial regulation of railway rates is of slight importance and does not vitally affect our problem both because of the limited powers of the Provinces and the absence of purely provincial lines.

The first method by which public control was exercised was by the common law. Canada's common law comes from England and to point out the method by which railroad rates come within its scope requires some reference 
to early English cases upon the subject. When the first railways were incorporated, by analogy they were conceived of as of the same nature as turnpike or toll roads and canals. ${ }^{1}$ Hence it was agreed that tolls were to be paid for their use by common carriers between whom it was contemplated competition should exist. A railroad, according to this view, was merely a superior road and fulfilled its function by providing a better roadway for the carriage of goods than a metaled road. Thus, in the beginning the carriage of the goods and the providing of the road were dissociated, just as in the case of turnpike roads and canals they are dissociated to-day. The proprietors of the roads, however, were further empowered to convey goods if they chose. If they elected to do so they came within the common law of carriers themselves with the obligation to carry goods for all persons indifferently, "on being tendered a reasonable compensation." 2 We may pass over the early discovery that railroads were not in their nature fitted for operation by every carrier who wished to employ them, but were essentially meant for unified control. However, this point is important, as the proprietors of the road also became the operating carriers, common-law methods of relief were open to shippers who felt that they were being unjustly imposed upon. But as a matter of fact in Canada this mode of relief has been practically never used. Indeed, even after statute law eased the way for judicial appeal, there was but little recourse to the courts in connection with rates. Digests for the Province of Quebec to 1878 do not show a single case reported turning upon the reasonableness of the charges

1 "That all persons shall have free liberty to pass along and upon and to use and employ the said railway with carriages properly constructed as by this act directed, upon payment only of such rates and tolls as shall be demanded by the said company," etc. Section 163, Great Western Act, 5 and 6 Wm. IV, c. 207 (1836).

2 Palmer 08. the Grand Junction Railway, 4 Meeson \& Welsby, 749 (1839). 
made for carriage. ${ }^{1}$ The same holds true for New Brunswick $^{2}$ and Nova Scotia. ${ }^{3}$ In Ontario ${ }^{4}$ in a single instance ${ }^{5}$ where a complaint of discrimination was laid the decision turned on a clause in the incorporating act, as the commonlaw duty to carry for a reasonable toll as then developed did not import the further duty to carry goods for all customers at the same rates. ${ }^{6}$

The real significance of the absence of litigation in respect to tolls appears to be lack of grievance. In the early days of railroad development there was such a strong demand for facilities that in obtaining the convenience of rapid transit incidental evils were lost sight of. Possibly, too, the failure of the common law to cover adequately the case of discrimination by shutting off the hope of relief prevented appeals to the courts arising from that fruitful source of complaint. Moreover, statutory regulations appeared in 1851 and before that time railroad development was so slight and unimportant that we should hardly expect much recourse to the law on questions of rates. This particular phase of litigation naturally appeared later, when the cardinal principles in the common law of carriers had been comprehensively codified or were embedded in the railway companies' charters of incorporation. ${ }^{7}$ Appeals to the court would then naturally tend

1 C. H. Stephens, B.C.L., Quebec Law Digest from 1810 to $187 \%$.

Andrew Robertson, K.C., A Digest of all the Reports Published in Lower Canada to 1863.

2 J. G. Stevens, Stevens's Digest, 1825 to 1879.

3 F. T. Congdon, Congdon's Nova Scotia Digest.

4 The Digest of Ontario Case Law.

- The Attorney-General vs. The Ontario, Simcoe \& Huron Railway Company, 1858. 6 Grant's Chancery Reports, 446.

- Scott vs. Middleton, 33 U.C.R. 580.

7 MacMurchy and Dennison on section 284 of the Canadian Railway Act: "In three particulars, however, railway companies differ from common carriers on account of the provisions of this act, (1) their right to limit their liability by contract is curtailed; ( 2 ) their tolls must be equal; (3) they are by this and other sections subject to the general supervision of the Board of Railway Commissioners." MacMurchy and Dennison, Railroad Law of Canada, p. 449. 
to hinge on the provisions of the code. Of course, common-law principles continued to afford a means of relief in cases of tort or contract, but these lie without the scope of this study.

$\S 2$. Railroads in Canada have always had to apply to the Federal Parliament or to the Provincial Legislature for their charter of incorporation. Provisions in the very earliest of these charters indicate that the Legislature had the subject of rates under advisement. But the nature of the provisions suggests rather the early extravagant views of the promoters and the public as to the pecuniary returns to be derived from these new forms of enterprise than any very serious anticipation of evils. The first instance of railway legislation in Canada is found in the Province of Quebec in 1832. In that year the Champlain \& St. Lawrence Railway secured a charter ${ }^{1}$ for a railroad from the Port of St. John's to the River St. Lawrence. On this occasion the legislative assembly, after examining witnesses as to the level of charges that then prevailed between these two points, fixed a maximum rate for both freight and passenger service. ${ }^{2}$ Another clause of the charter provided that for every one per cent increase of dividend over twelye per cent, there should be a five per cent reduction in the tolls the following year. In order that this might be accomplished, it was provided that there should be an annual return submitted to the Legislature showing the result of the operations for the year. Thus the publicity of railroad accounts was taken for granted in the first charter authorized.

In New Brunswick the charter of the St. Andrews \& Quebec Railway reveals extravagant hopes of gain. ${ }^{3}$. The rates were to be reasonable and under the control of the company, but after ten years, if the Legislature deemed

$12 \mathrm{Wm}$. IV, c. 58 (1832).

2 Journal of the House of Assembly of Lower Canada (1831), Appendix, Feb. 28 (1831) ff. Also appendix (1831-2), Dec. 26, 1831.

$86 \mathrm{Wm} . \mathrm{IV}$, c. 31 (1836). 
them excessive, it might reduce them so that profits should not exceed twenty-five per cent. In Upper Canada the Legislature left the power of determining rates to the president and the directors. ${ }^{1}$ The early legislation here followed the English models closely and accepted their view of competing carriers utilizing the same line.

Limitation of rates on the basis of dividends met with 1 public criticism in the Province of Quebec as likely to discourage the investment of capital in desirable enterprises. ${ }^{2}$ It was feared capital would migrate to other Provinces where restrictions were not so severe. Perhaps that is why in later charters granted by Quebec the restrictions do not appear in so rigid a form. In the St. Lawrence \& Industry Railway charter, secured in 1847,3 while tolls are to be ordained by by-law without giving privileges or undue advantages, there are no provisions for automatic reduction. A tax, however, is to be laid in case the profits exceed twenty-four per cent. In the Atlantic \& St. Lawrence Railway charter, ${ }^{4}$ while maximum rates are set forth, to be charged equally, a tax is also to be imposed if the earnings exceed twelve per cent. There was thus wide variation in the various acts of incorporation, but clearly the main ends sought were to repair the deficiencies of the common law with respect to discrimination and to prevent $f$ unduly high rates. At the same time the way was left open for indefinitely large profits.

Charter control was not altogether supplanted by the later policy of general railway acts. The general acts, as the adjective implies, were rather designed to collect the

$14 \mathrm{Wm}$. IV, c. $28 ; 4 \mathrm{Wm}$. IV, c. 29 (1834).

2 Thus the Montreal Gazette of December 29, 1835, finds fault with Hon. L. J. Papineau in connection with the line from the St. Lawrence to Kennebec because he wished to limit profits to twelve per cent, when in the United States the Gazette averred railways "divided even as high as fifty per cent upon their capital, without being alarmed at the bugbear of high prices."
\& 10 \& 11 Vic., c. 64 (1848).
18 Vic., c. 25 (1845). 
provisions that were "usually inserted" 1 in charters, while leaving to the charter itself peculiar features suitable to the individual road. The charters include as part of the act of incorporation the general act unless expressly varied. Moreover, when they have been varied it has usually been within the act by providing for more stringent restriction. An example of this is found in the comparatively recent charter of the Canadian Pacific Railway, which provides for a reduction of rates if the net earnings of capital exceed ten per cent, whereas under the general act the level at that time was fifteen per cent. Charter control of rates, however, has been of no consequence. To say nothing of other difficulties, the maximum set before control became effective has been too high. Class rates and even commodity rates might press with severity upon the shipper before the earnings of the company would mount to fifteen or even to ten per cent. These provisions really represent the first experiments by the Legislatures of the Canadian Provinces to prevent the railroad companies from levying an undue toll upon the people without at the same time discouraging railway enterprise.

An example of legislation, which is neither a case of pure charter granting nor yet general law, is afforded by the Crowsnest Pass Railway agreement. ${ }^{2}$ This agreement was entered into by the Dominion Government and the Canadian Pacific Railway. For certain aid extended to this branch, the Canadian Pacific Railway agreed to give reduced rates on a schedule of goods comprising traffic moving between Eastern and Western Canada. That is, for aid granted to one portion of its line, it agreed to give reduced rates on another portion. This agreement does not represent, therefore, a clear case of charter control, nor does it arise from a consideration of the large profits being

1 Journals of the House (1851), Eighth Report of Select Committee on Railways and Telegraph Lines, Appendix UU.

2 60-61 Vic., c. 5 (1898). 
made by the railroad in question. Charter control of rates being based, as we have seen, on a conception of generous profits before regulation began, never became effective. The forces which finally led to comprehensive rate control did not arise from a consideration of large profits being made by the railway companies, but from other causes.

§ 3. Statutory control began to be exercised in 1851 when the first general railway act was passed. ${ }^{1}$ As already noted, the aim was to "consolidate in one act certain provisions usually inserted in acts authorizing the making of railways." The bill followed the English Act of 1845 in most of its features, dealing quite elaborately with the powers and organization of a railway, procedure in taking land, and the operation of a line. In respect to tolls it provided that they were to be fixed by by-law and there was to be no "undue advantage, privilege, or monopoly afforded to any person or class of persons." All tolls before being levied were to be approved by the Governor-inCouncil. This latter provision represents a modification of the Imperial Act, the select committee considering the Executive Government to be the best substitute for the English Board of Trade. ${ }^{2}$

Revisions and consolidations of the Railway Act left these main clauses practically untouched until 1888 . In that year, prior to changes in contemplation with a view to quieting criticisms of railway policy and practice, an extensive investigation of the methods of railway control was conducted by a Royal Commission. ${ }^{3}$ The report of this Commission is noteworthy, because on its recommendation an important change in the policy of railway control was initiated. The Commission recommended the crea- $t$ tion of an "independent tribunal" " 4 to deal with rates and "generally to regulate the system of railway management

1 14-15 Vic., c. 51 (1851).

2 Journals of the House (1846), First and Second Report of Select Committee, Appendix R.

- Report of the Royal Commission on Railways (1888). ' Ibid., p. 12. 
in its relation to the commerce of the country." It also sugI gested the establishment of uniform classification except for through traffic to and from the United States. ${ }^{1}$ In regard to uniform rates on freight carriage it declared that "the competition by water and rail from almost every important business center in Canada forbids the adoption of uniform mileage rates." 2 Unfortunately the Royal Commission, when it came to the determination of the form of tribunal it should recommend, rather inconclusively decided against an administrative body of the nature of the Interstate Commerce Commission of the United States. Holding that the Canadian system of government, with its insistence upon ministerial responsibility, precluded an "irresponsible" body, the Commission recommended that the Railway Committee of the Privy Council be given wider powers and constitute the new tribunal. The scheme contemplated an elaborate system of preliminary reference to officers in each Province, who could take evidence, decide cases, and from whom appeal would lie to the committee itself. This feature was considerably modi- fied in the bill finally adopted by Parliament. A simple clause was inserted providing that the Committee could appoint an officer to take evidence. Otherwise these recommendations were accepted by Parliament and became rlaw. ${ }^{3}$ The clause conferring powers on the Railway Committee became the foundation of the jurisdiction later inLherited by the Board of Railway Commissioners.

The revision of 1888 thus marks the entering wedge of broad administrative control. In another respect this revision is something of a landmark. The clauses of the act dealing with rates and traffic are set forth with much more particularity than in previous enactments. In fact the measure indicates the definite emergence of methods to control problems of this nature. Though the railways

1 Report of the Royal Commission on Railways (1888), p. 12.

Ibid., p. 13.

- 51 Vic., c. 29 (1888). 
were guaranteed the right to fix tolls for "large quantities" or for "long distances" at "proportionately less" than for "small quantities" or for "short distances," rates| were to be charged equally to all persons. Neither were reductions to be for quantities of less than "one carload of at least ten tons." Thus with 1888 the outlines of the present system of public control over railway rates begin to appear, as yet, however, only in outline.

The Royal Commission in its tour of inquiry had not visited the Northwest and it was from that part of the country that complaint soon came. ${ }^{1}$ The legislative assemblies of Manitoba and of the Northwest territories, farmers' organizations and other organized bodies, charged the Canadian Pacific Railway with exacting exorbitant rates. ${ }^{2}$ At length in 1894 to meet a chorus of complaint, Hon. John Haggart, Minister of Railways and Canals, appointed a Departmental Commission to investigate the grievances. This Commission held sittings in Winnipeg and other Western centers, investigating the rates on grain, lumber, coal, merchandise, and dairy products. By comparison of rates on contiguous American territory through schedules presented by the Canadian Pacific, the Commission decided that Canadian shippers were getting better rates than their neighbors across the line. A single exception was admitted; on agricultural implements the rates were found to be higher than in North Dakota. With this exception the Commission declared that "the comparison does not bear out the charges that the rates in Manitoba and the northwest were either exorbitant or excessive." 8 The comparison of rates based on Eastern lines, presented by the complainants, was rejected as unfair, and in the face of this ruling their case crumbled. In the event

1 Report of the Railway Rates Commission (1895).

2 An Open Letter to the Shareholders of the Canadian Pacific Railway Company. Issued by the authority of the Winnipeg Board of Trade and the Brandon Board of Trade, October 1, 1887.

3 Report of the Railway Rates Commission (1895), p. 12. 
the result of the investigation was held to be a complete confutation of the charges. The Canadian Pacific Railway's defense was accepted and it was completely exonerated, the Commission observing "an apparent desire on the part of the company to give every possible inducement by favorable rates and additional facilities to any person desirous of embarking in any new industry that would add to the business of the west or the traffic of the road." 1 An eminently safe conclusion! As the case was drawn there can be no doubt that the Canadian Pacific Railway was able to vindicate itself, particularly as the attempt of the complainants to raise the broader issue of the railway's obligation to the West in view of the heavy subsidies received there, was brushed aside. The Commissioners were obviously pro-railway in their sympathies and apparently intent upon a ruling rather than upon the amelioration of distress.

The natural result was that rate grievances were soon to the front again, but this time discontent was more general, being present in the East as well as in the West. This time Professor Simon McLean, of the University of Toronto, was instructed to investigate the causes and to suggest a solution. His first report was presented in 1899, a careful review of methods of railway control, with special attention devoted to English, American, and Canadian experience. ${ }^{2}$ Professor McLean strongly favored a commission of the American type with due modifications to suit Canadian conditions. In regard to the Railway Committee of the Privy Council he said: -

$r_{\text {The defects of the Railway Committee as regulator of rail- }}$ way transportation I would place under the following heads: -

(1) it has a dual function - political and administrative;

1 Report of the Railway Rates Commission (1895), p. 15.

2 Reports upon Railway Commissions, Railway Rate Grievances, and Regulative Legislation (1902). 
(2) the lack of migratory organization renders it impossible to deal effectively with complaints;

(3) the distance to be travelled by the complainants renders the expense too great;

(4) there is a lack of technical training for the work;

(5) the existing organization is not sufficiently permanent. ${ }^{1}$

As an illustration of its ineffectiveness as a rate tribunal Mr. McLean pointed out that of four hundred and eight cases that came before it between January, 1889, and December, 1896, only seven dealt with rates, and one of these was dismissed because the Committee had no jurisdiction. He attributed this to the expensiveness of the procedure, declaring that country communities had not had their interests adequately protected, and that many legitimate complaints had not come before the tribunal.

Mr. McLean was instructed to continue his investigation and in 1902 submitted a further report dealing specifically with rate grievances in connection with Canadian railways. ${ }^{2}$ Classification, distributive rates, competitive and non-competitive traffic, minimum weights, discrimination, excessive charges, and other causes of complaint were in turn investigated and reported upon. In each instance the need and ability of a mobile, inexpensive, technically equipped commission to handle the problems involved was vigorously set forth. The whole report was thus an imposing argument for the displacement of the Railway Committee and the establishment of a commission. The report carried conviction and the end advocated was attained by the Railway Act of $1903^{3}$ which established the present Board of Railway Commissioners.

§ 4. The Canadian Board of Railway Commissioners is thus the product of considerable experimentation in railway control. It represents the latest step in an evolution that has gone on under the prod of discontent and dissatis-

1 Reports upon Railway Commissions, Railway Rate Grievances, and Regulative Legislation (1902), p. $37 \mathrm{ff}$.

The two reports are bound together.

3 Edw. VII, c. 58. 
faction for over half a century. The final adjustment was made in 1903 in response to an unsatisfactory rate situation, but the solution on that occasion went beyond the immediate cause and endeavored to place the controlrelationship of the Government to the railways on an adequate and permanent basis. In the attempt to accomplish this end English and American experience was freely drawn upon and through the medium of Professor McLean's reports made easily available to the Minister of Railways, Hon. A. G. Blair, and the other legislators who were shaping the bill. As a result the measure combines the solid teachings of experience with the most advanced and most carefully thought-out methods of public control. No piece of legislation enacted in recent years in Canada has won greater approval. "The history of the Railway Commission since its establishment in 1903 has been one of constantly expanding jurisdiction. The original act conferred powers greatly in excess of those enjoyed by the Railway Committee and by the Legislature and judicial decisions since that time the jurisdiction of the Board has been extended and confirmed until as an executive and judicial body it now exercises a quite unique authority." 1

The Act of 1903 created a Board of three commissioners appointed by the Governor-in-Council, to hold office for a period of ten years. ${ }^{2}$ Unless disqualified by age, commissioners might be reappointed. One commissioner was to be Chief Commissioner of the Board, and a second Deputy Chief to act in the former's absence. To the Chief Commissioner was given the power of determining any question which in the opinion of the commissioners was a question of law. An amendment to the act in $1908^{3}$ increased the number of commissioners to six and provided for an Assistant Chief Commissioner. The office of Chief

1 MacMurchy and Dennison, op. cit., p. 49.

2 Professor McLean recommended life tenure; op. cit., p. 78. The age limit is seventy-five years.

$37 \& 8 \mathrm{Edw}$. VII, c. 62. 
Commissioner was limited to a judge of a superior court or an advocate or barrister of ten years' standing. The power of the Board to hold sittings elsewhere than at Ottawa was extended to permit of more than one sitting being held at the same time. Two were constituted a quorum, except in an ex parte application, when one commissioner might act. Ample provision was made for a staff of experts to enable the Board to carry on its work of inspection and control. For the year ending March 31, 1916, apart from the commissioners the permanent staff consisted of ninety-one members, of whom thirteen belonged to the traffic department, eleven to the engineering department, and twenty-one to the operating department. ${ }^{1}$

The Board has power ${ }^{2}$ to inquire into, hear, and determine any complaints arising out of a failure to fulfill the requirements of the Railway Act, "or any special act or regulation made thereunder by the Governor-in-Council, the Minister, the Board, or any inspecting engineer." It inherits all the powers of the Railway Committee of the Privy Council. It may issue mandatory and restraining orders, and has, in regard to attendance, the production of documents, and the enforcement of orders, all the powers of a Superior Court. The appointment of a receiver does not oust its jurisdiction. It may act upon its own motion, may review its own orders. It is a court of record and as such its findings are authoritative as to fact.

For the purpose of the act it has full jurisdiction "to hear and determine all matters whether of law or fact." "Its decisions are reviewable only by the Governor-inCouncil and in certain cases by the Supreme Court of Canada. Even when it acts without jurisdiction, objection must be taken in this way and cannot be taken in collateral proceedings in any court." 3

1 Eleventh Report of the Board of Railway Commissioners, p. 392.

2 Sections $10 \mathrm{ff}$. of the Railway Act.

- MacMurchy and Dennison, op. cit., p. 49. 
To these extensive powers were added in 1908 a limited jurisdiction as to agreements. ${ }^{1}$ In case of a breach of agreement touching "the provision, construction, reconstruction, alteration, installation, operation, use, or maintenance" of "any structure, appliance," etc., in connection with a railway, the Board may hear and make an order reasonable and expedient and take the necessary steps to enforce the same. These powers trench on the domain of the common law and give the Board something of an equity jurisdiction. The line of demarkation has not yet been clearly defined by judicial interpretation. It is evident that even wider inroads are to be made upon the jurisdiction of the ordinary courts. In a consolidation of the Railroad Act before Parliament since 1914 provision is made for the refund of payments in excess of the legal toll, ${ }^{2}$ a provision that naturally grows out of the Board's powers to determine when rates are excessive or unfair. Indeed, successive amendments to the act are continually enlarging its scope.

In certain respects the Board as it is at present constituted is unlike a court. The latter remains the ordinary avenue of relief for cases arising out of tort, and, with the exception noted, of contract. The Board does not award damages nor is it retroactive. Its decisions are remedial and corrective in intent, endeavoring to remedy a condition rather than to punish a dereliction. ${ }^{3}$ Thus, in the Eastern Rates Case the railways filed an exhibit showing that, in complying with the orders of the Board in matters affecting safety and protection, there had been a capital expenditure down to December 31, 1913, of $\$ 3,073,736.23$ and that the amount spent in 1914 was $\$ 416,349.27$. In addition to this, charges for maintenance and operation, necessitated by orders of the Board, in connection with

1 Section 26 A, 7-8 Edw. VII, 61. 27 Geo. V, c. 13 (1917).

3 Cp. Judgments, Order, etc., of the Board of Railway Commissioners for Canada, vol. vi, p. 37. 
highway crossing protection, fire protective appliances on locomotives, inspection of cars for compliance with safety standards, etc., were computed at $\$ 112,332.56 .^{1}$

In cases of rates when a complaint is made the onus of their reasonableness lies upon the railways. The Board does not originate rates but may indicate in a given instance what would be a reasonable charge. Its dual aspect as an administrative commission and a quasi-judicial body is well exhibited by the rights of appeal. "Due process" is conserved by the right of appeal to the Supreme Court upon questions of jurisdiction, but the "appeal shall not lie unless the same is allowed by a judge of the same court." 2 "On the hearing of any appeal the court may draw all such inferences as are not inconsistent with the facts expressly found by the Board." The Board may also, on its own motion or upon the application of any party, state a case for the Supreme Court, "upon any question which in the opinion of the Board is a question of law."

On the other hand, the objection that the Board might be independent of Government control, with practically "irresponsible authority," ${ }^{3}$ urged by the Royal Commission of 1888, has been obviated by retaining an appeal to the Governor-in-Council. "The Governor-in-Council| may at any time in his discretion, either upon the petition of any party, person, or company interested, or of his own motion and without any petition or application, vary or rescind any order, decision, rule, or regulation of the Board, and any order which the Governor-in-Council may make with respect thereto shall be binding upon the Board and upon all parties." Since the organization of the Board there have been thirty cases carried to the Supreme Court, twenty-seven of these have been disposed of, eight-

1 Judgments, Orders, etc., of the Board of Railway Commissioners for Canada, vol. vI, p. 251 .

$23 \mathrm{Edw}$. VII, c. 58, secs. 55-56.

Ante, p. 80. 
een appeals being dismissed and nine allowed. There have been seventeen appeals to the Governor-in-Council up to March 31, 1916; of these ten have been dismissed, three have been allowed, two were withdrawn, and two are still pending. In nine cases decisions affecting rates and traffic have been appealed to the Supreme Court. In three of these cases the appeal was allowed on questions of jurisdiction.

Being a statutory tribunal the Board of Railway Commissioners must rely for its authority upon the Canadian Railway Act. A warrant must be found in the act for its orders or they are null and void. ${ }^{1}$ If we turn to the act we find its most noticeable feature to be the wide reach of control that it assumes and has given into the custody lof the Board. The only limitation upon the power it has conferred are the terms of the Act of Confederation which are binding upon the Dominion Parliament. By this act railways connecting one or more Provinces are under the control of the Federal Government. Any other railroad may be brought under its control by Parliament legislating that the line is in "the general interests of Canada." Under this provision the Parliament of Canada has brought most of the railways in Canada under its control, no matter whether their charters antedated general Dominion legislation or were granted by one of the Provinces. A continuous process of extension of control is going on. The Act of 1903 has been amended nearly twenty times and been consolidated once. Another consolidation is on the way. The feature of these amendments is the widened range of activity they have opened to the Board. Express companies, telegraph and telephone lines, and electrical power when obtained from water power leased from the Crown have all been brought within its purview. An attempt is being made to extend its control to rates and facilities in connection with overseas carriage and com-

1 Grand Trunk Railway vs. City of Toronto, 1 C.R.C. 92. 
munication with the concurrence of the Imperial Parliament. "The evident tendency of recent legislation is to place all matters connected with the methods of railway construction and operation under the exclusive control of one authority," 1 declares a leading Canadian authority. The signs of the times are not lacking that an even more extensive control is contemplated - a control that comprehends all the instruments of transportation.

The powers of the Board as exercised fall into three broad divisions: the initial location and construction of a line; ${ }^{2}$ regulations covering safety and convenience in operation; and the regulation of tariffs and tolls. It is to be remembered that the first Canadian Board of Railway Commissioners was authorized in connection with the construction of the trunk line by the Act of $1851 .^{3}$ Their certificate that the line had been duly built was a necessary prerequisite to the payment of Government aid. The Consolidated Act of $1859^{4}$ expanded its functions to include reports on lines to be built, and the sanctioning of the opening of roads. ${ }^{5}$ The latter provision was inserted in the interests of public safety. The present act enlarges upon these duties. ${ }^{6}$ The present Board has now a secondary control over the location of the line. After the general plan has been submitted to the Minister of Railways and Canals and approved, the railway company must prepare and file with the Board a plan, profile, and book of reference which must be approved. Further, the Board controls the taking of land of other companies where this is considered desirable in the public interest, and may authorize a company to use "the right of way, tracks, terminals, stations or station grounds of any other railway company."

1 MacMurchy and Dennison, op. cit., p. 49.

2 These powers are likely to be greatly enlarged in the not distant future.

3 14-15 Vic., c. $73 . \quad$ Consolidated Statutes (1859), c. 66.

- Powers later absorbed by the Railway Committee.

- Sections 150, 263. 
Further, the Board approves the construction of branch lines not exceeding six miles in length, crossings, junctions, highway diversions, and connections with intersecting lines. No railway or branch may be opened for traffic until favorably reported upon by one of the Board's engineers, and an inspecting engineer may forbid the operation of a line "until alterations, substitutions, or repairs are made thereon." Of 2803 applications made to the Board for the year ending March 31, 1916, at least one half grew out of these provisions of the Railway Act. ${ }^{1}$

The measures for safety and convenience of operation ${ }^{2}$ include the general requirement that every railway company shall use modern and efficient apparatus and the Board has the authority to determine when the apparatus is efficient. The Board must also provide for the uniformity of rules for the operation and running of trains, as well as for the rate of speed in cities, the installation of safety devices, and accommodation for traffic. These are important features of the Board's duties under the act. During the year 1914-15 one hundred and sixty-four applications were made in connection with the safety of bridges, in 1915-16, sixty-nine, while the location and maintenance of stations were responsible in 1914-15 for two hundred and fifty-seven, in 1915-16, one hundred and twentyseven. ${ }^{3}$ The number of these applications varies considerably, as they depend in part upon the amount of railroad construction in progress. Thus, for the year ending March 31, 1915, covering a period when considerable length of line was approaching completion, the total number of applications made to the Board was 4047.

The positive enactments of the statute in connection with tolls and traffic are contained in forty-seven sections, ${ }^{4}$ which set forth in particular as well as generic terms the

1 Eleventh Report of the Board of Railway Commissioners, etc., p. 415.

2 Sections 264 ff. $\quad$ S Tenth Report, p. 438; Eleventh Report, p. 415 ff.

- Sections $314 \mathrm{ff}$. 
obligations of the railroads to the public in their capacity of common carriers. Tariffs are to be prepared under the authorization of by-law and must be submitted to and approved by the Board. In actual practice the interested shippers and the representatives of the railways endeavor to resolve their differences before a formal case in connection with the validation of a tariff comes before the Board. There is considerable latitude given to the commissioners. The equality clause provides: "all such tolls shall always, under substantially similar conditions, in respect of all traffic of the same description, and carried in or upon the like kind of cars, passing over the same portion of the line of railway, be charged equally to all persons and at the same rate, whether by weight, mileage, or otherwise." The long- and short-haul sub-section, however, is retained from the earlier act and provides that "the tolls for larger quantities, greater numbers, longer distances may be proportionately less than the tolls for smaller quantities or numbers, or shorter distances, if such tolls are under substantially similar circumstances, charged equally to all persons." Tolls shall not be greater for a shorter than for a longer distance in the same direction over the same line unless the Board deem it expedient owing to competition.

Pooling is prohibited except at the discretion of the Board.

Service and facilities are to be provided without discrimination. Companies must "afford to all persons and companies all reasonable and proper facilities for the receiving, forwarding, and delivering of traffic upon and from their several railways, for the interchange of traffic between their respective railways, and for the return of rolling stock."

The Board has complete authority over freight classification. "The tariff of tolls for freight traffic shall be subject to and governed by that classification which the Board 
may prescribe or authorize, and the Board shall endeavor to have such classification uniform throughout Canada, as far as may be, having due regard to all proper interests." For international traffic it may" approve of any classification of use in the United States.

Tariffs are to be divided into three classes: the standard freight tariff, special freight tariffs, and competitive tariffs. All of these must be filed and approved. Where an increase in rate is contemplated, ten days' notice must be given; in case of reduction, three days. Competitive tariffs, however, under certain regulations of the Board, "to meet the exigencies of competition may be acted upon immediately and put in operation immediately upon the issue thereof, by the company, before they have been filed with the Board."

Joint tariffs are to be filed by the initial company and the other companies affected must notify the Board of concurrence. In the case of agreements concerning carriage by water between Canadian ports, with railway connections, commodities shall be deemed to be carried by a continuous route. When there is a failure of two or more companies to arrive at a joint tariff for what the Board considers "a reasonable and practicable route," it may "by order determine the route, fix the toll or tolls, and apportion the same among the companies interested." Joint tariffs must also be filed for international traffic, as well as for traffic passing from one point in Canada to another by foreign lines.

These are the principal provisions of the Railway Act relating to tolls and traffic. They amply clothe the Board with authority to regulate the rates and service in the interests of equality and justice. Moreover, the continuous amendment of the act with a view to more effective and wider control has enabled the Commission to strengthen its authority where a weak point has been disclosed by experience. In respect to the number of applications made under the tolls section of the act, however, they were 
quite markedly in the minority compared with applications under other sections. For the year 1915-16 applications that could in general be brought under this head numbered one hundred and twenty-three. Of this number twenty-two had to do with interswitching, twelve with freight classification, and nine with standard freight tariffs. Thirteen more dealt with special tariffs and nine with carriage by express. ${ }^{1}$ These are the main classes into which the applications fell. The other cases are scattered over a variety of complaints of varying degrees of importance. The number and grouping of these applications are typical of the distribution of cases of this nature since the Board took up its work.

A statistical analysis of decisions rendered is not an indication of the importance of this function of the Board. Many of the adjustments which the Board is called upon to make in its other capacities are of local importance only, but the incidence of a rate decision or traffic adjustment extends far and wide, affecting not only the parties directly applying, but, through its influence upon prices and production, a wide area of consumers and producers. Rate decisions have a general importance that no other class of decisions that the Board is called upon to make, possesses. The Western Rates Case, adjudicated in 1914, affected the people of the four Western Provinces, and, in scope of influence, exceeded in importance any previous decision of the Board. The Eastern Rates Case of 1916, granting a general increase in tolls to railway companies operating in Ontario, Quebec, and the Maritime Provinces, directly touched the producing costs of the great bulk of home-manufactured goods consumed by the Canadian people. The absence of a greater number of complaints is probably due also to the careful supervisory work of the Board in connection with the initial issuance of tariffs and classifications.

1 Eleventh Report of the Board of Railway Commissioners, p. 415. 
To recapitulate, briefly, the scope of the Board includes: (1) supervision of the initial location of lines, sidings, and switchings, with inspection before they are put into use; (2) regulations covering the safety and convenience of lines in operation; (3) regulations covering freight classification, tariffs, and tolls; and (4) the investigation and adjudication of complaints of injustice with respect to any of these features.

- As already pointed out, of these duties the problem of determining equitable rates has from the first been one of the Board's most important tasks. In connection with other duties the Board has in the main been the legatee of the Railway Committee of the Privy Council and the earlier Board of Railway Commissioners. But the power to determine equitable rates is the distinguishing characteristic. Because of this fact an examination of the theories which have guided the Board in making its awards has been selected as the major part of this study. The aim is to examine these decisions in the light of the historical background with which the first part of this study has dealt. We have seen the gradual development of transportation systems by both land and water, growing up under the influence of active State sympathy and help. We have also seen the gradual evolution of means of public control lest these systems become huge Frankensteins injurious to the private citizens and to the State. The mediating body between these two classes of ideas is the Board of Railway Commissioners. Hence, while this study hopes to present the development of principles of rate theory in Canada, its larger purpose is to show that these principles are a natural outgrowth of or reaction to Canadian geographical facts and Canadian transportation history. 


\section{PART II}

\section{RATE REGULATION AND THE BOARD OF RAILWAY COMMISSIONERS}





\section{CHAPTER VI}

RATE THEORIES DEVELOPED IN CONNECTION WITH THE CHARGE OF EXCESSIVE RATES

§1. In the twelve years of its history approximately two hundred and fifty cases of importance, in which the issue touched rates, have come before the Board of Railway Commissioners for Canada. While all of these cases have concerned tolls, the precise form of the problem has varied from the direct appeal for relief against excessive rates to less obvious charges of discrimination or injustice in the matter of terminal interswitching, refusal to agree on joint rates, or some similar complaint with implications of rate injustice. There has been a correspondingly wide variation in the importance of these decisions. The value of a decision may be estimated in two distinct ways. A relatively simple case, possibly because of the absence of disturbing factors, may draw forth an enunciation of principle thereafter applied and confirmed in later adjudications as the Board's settled ruling on that phase of rate determinations. On the other hand, there are cases which challenge examination either because of the wide social or commercial interests at stake or because of the keenness with which the whole is presented. In these cases the decision may rest finally upon principles previously developed and adopted.

Our business is primarily with the first type of judgment, but since no two cases are exactly alike and since principles of adjudication are modified, narrowed, or expanded by different collateral circumstances, there will be occasion to refer to and examine a wider range. It does not seem necessary, however, in entering upon this sur- 
vey of the Board's rate theories to go beyond the data which the opinions of the Board afford. Fundamental rate theories have been adequately enough explored for the present purpose by several writers, so that the task here may be limited to setting forth the relative extent to which each principle of rate-making familiar to students of economics has become a part of the policy of the Board. As already stated this, indeed, is the central aim of the study: to discover and appraise the relative importance of the economic theories which guide the Canadian Railway Commission in determining what are fair and reasonable rates, and to show in what degree their relative importance is a natural outcome of the Canadian railway situation. In addition, an attempt will be made to estimate the influence of the Commission on Canadian commercial development.

There are three main categories into which appeals against railway tolls have fallen. It is charged that the rate in itself is unreasonable or excessive without regard to what rates exist upon other traffic. The transaction is viewed as one solely between the particular shipper or body of shippers and the carrier or carriers. Rates granted to other goods are not in question. Secondly, it may be charged that the rate is unfair or unduly discriminative. In this instance the basis of the attack is an invidious comparison between the rates in question and those accorded to other traffic. The third group of cases relate in the main to occasions where the rate is not alleged to be either excessive or discriminative in the narrower sense but where the shifting currents of competition and trade have tended to increase rates which before were on a lower scale, or where the Board has been asked to protect or extend a rate granted under special circumstances or conditions. The considerations which have been urged in cases of this sort largely concern the wider problems of commercial development. 
In the determination of cases under the unique conditions which obtain in Canada the Board has developed a body of doctrine which within the Dominion is at once a counsel of perfection to the rate-maker and a ground of appeal to the shipper against felt injustice. The findings of the Board have a wider interest also in so far as the problems solved represent applications of known principles to new conditions. As there will be occasion to point out later on, the Board has profited by the experience of the regulative bodies of England and of the United States, but while that is true it has a tradition of its own built upon its own experience. Since its organization it has been called upon to consider nearly every phase of the rate problem and to justify its decision upon the basis of its own reasoning. We may therefore turn to its opinions with some confidence that the main lines of rate theory as developed in Canada by the Board are laid down and are capable of definition.

The task of propounding rate theories in this connection has devolved largely in Ca saba upon the railway companies. This is easily accounted for. The Board has repeatedly held that the previous existence of a particular rate voluntarily established is evidence of its reasonableness, and that the onus of disproof rests upon the party desiring to disturb existing arrangements. ${ }^{1}$ In the great majority of cases the railroads have been the parties who desired to make a change. But, by this presumption, whenever they have wished to advance their tolls they have had to be prepared to justify the change before the Board. In two or three important cases the attack has been upon existing rates as excessive, but generally the problem has come before the Commission in the other form.

$1 / 73 ; 3 / 148 ; 5 / 207 ; 7 / 270 ; 7 / 233 ; 5 / 269$. (Note: Reference unless otherwise stated is to the Annual Reports of the Board. The first figure gives the number of the Report - the second the page; e.g., 1/73: First Report of the Board of Railway Commissioners for Canada, p. 73.) 
In regard to the principles upon which railway rates should be based the Board very properly has adopted a cautious attitude, and has refused to lay down general criteria of reasonableness. In a general order in respect to joint freight and passenger tariffs the Board was asked to sanction the presumption that where joint rates exceeded the sum of the local rates they were unreasonable. The Board held that the unreasonableness of a rate or rates should be established as a matter of fact and not as a mere presumption. "It is impossible," it said, "to determine the reasonableness of a rate aside from the concrete conditions it is concerned with." "There is no yardstick of reasonableness." 1 Thus again recently, in June, 1916, the Board dealt with the general structure of rates in Eastern Canada in the Eastern Rates Case and authorized increases, in some instances quite substantial. Shortly afterwards the railway companies made application to be permitted to increase materially their import rates, on the ground that they were on a relatively low basis. The Board, pointing out that the imporit ates were closely related to the general schedules passed upon in the Eastern Rates judgment, refused to permit action until the effect of the latter could be clearly demonstrated. It declared:-

Theoretical demonstration really amounts to nothing. The actual traffic returns alone can show what, under the new conditions as developed, the railway situation will be. ${ }^{2}$

In other words, the Board has not been prepared to lay down a mechanical rule with which to measure rates. It has not been prepared, so far as appeals of that nature are concerned, to become a mere recorder of the automaticity of its own instrument of proof. It has realized the insufficiency of any one measure of reasonableness, and

$15 / 217$.

2 VI J.O.R.R. 381. (The Board of Railway Commissioners for Canada: vol. vi, Judgments, Orders, Regulations, and Rulings.) 
has relied upon different tests according to the actual circumstances of the case. But while there has been this careful reliance upon particular facts it is possible to reduce the Board's general position to more definite outlines. It is possible, indeed, in respect to the question of rates reasonable in themselves to find a fundamental holding within which all cases alleging excessive rates come, although the practical difficulty of applying this controlling principle to every case presented has led to the development of secondary tests of reasonableness. That is, in a number of instances the presence or absence of certain concrete circumstances or conditions have been deemed presumptive evidence that the rate in question could be shown, if probed more deeply, to traverse this fundamental position and therefore be denied.

\$ 2 . The fundamental holding of the Board is that. there shall be a fair return on the funds actually invested: in the enterprise. This position is emphatically taken in The Dawson Board of Trade $v s$. The White Pass \& Yukon Railway Company Case. ${ }^{1}$ The road in question has a mileage of 101.12 miles, running from Skagway, Alaska, to White Horse in the Yukon Territory. It is a link in the White Pass \& Yukon route to Dawson City. It was constructed in 1899-1900. The freight rates charged on considerable traffic were extremely high at first. Thus the ratio of the rate on car lots to the Skagway price of the commodity on many items was 100 or over. Naturally, this led to complaints. In 1909 the Board concluded that it had jurisdiction over through traffic upon this line and ordered tariffs filed. In 1911 the Board found the rates as filed excessive and ordered a substantial reduction. The company then took an appeal to the Governor-in-Council, securing from the Board successive suspensions of its order until the Council passed up the appeal. The Privy

1 The name of this company has been changed to the British Yukon Railway Company. 
Council gave the company leave to apply to the Board for a rehearing of the whole matter. As a result of the rehearing, the Board rescinded its order, the railway voluntarily agreeing to make certain reductions.

Not only does this case plainly exhibit the fundamental nature of this holding, but it also reveals the truth of the observation already made that secondary criteria of reasonableness are presumed to be in consonance with the main position. When the charge of excessive rates was first considered, ${ }^{1}$ the railway company, in its defense, cited figures which they claimed represented the cost of the road. The Board, however, pointed out that there was no means whereby the "costs submitted might be checked," and that there was no information to show that the figures were "conclusive of reasonableness." They were therefore passed over, and the controlling consideration in the first decision was a comparison between the rates on the mountain division of the Canadian Pacific Railway and the rates on the line in question. The results of this comparison was that the Board ordered a reduction of thirty-three and one-third per cent on all rates on passenger and freight service. The railway company then appealed to the Privy Council and obtained its permission to have a rehearing.

Meanwhile, as the appeal did not act as a stay to the operation of the order for reduction, the company also applied to the Board for a suspension of the order until the rehearing could be had. In making its application the railway submitted to the Board figures purporting to show that if the order for reduction had actually been in force for the year 1910, on the basis of the traffic carried, "the railway company would have been about $\$ 44,000$ short of enough money to pay the interest upon the outstanding bonds." In brief, the order of the Board would probably have forced the company into a receivership. 
In granting the stay ${ }^{1}$ until the rehearing the chairman of the Board said: -

The Board never intended to deprive these carriers of the opportunity of earning, first, not only enough to pay the interest upon their bonds, but, secondly, to pay a fair return upon the actual capital that went into the road and that is now outstanding in the form of stock. No controlling commission has got, it seems to us, the right or the jurisdiction to make an order that would have the effect of destroying the earning power of the capital that honestly went into the facility, and it is hardly necessary for me to reiterate that this Board never intended to make such an order, and if it is ultimately shown that the order we made has that effect, I take the responsibility of saying that it will be very promptly rescinded. ${ }^{2}$

Following the suspension of the order, upon instruction, the chief engineer of the. Board prepared an elaborate physical valuation of the road which showed a cost of $\$ 48,738$ per mile. He refused, however, to go on record as saying that the original construction did not cost $\$ 62$,000 per mile, the amount claimed by the company. The earnings of the company were shown to be declining and the disparity between the two sets of figures did not lead to a ruling upon the question of what valuation the Board would base its estimate of capital on. The Board remarked that in view of the lean earnings it was altogether likely that the stockholders would be glad to obtain earnings of "say 4 per cent" upon the engineer's valuation if that were possible.

In the face of this evidence the Board rescinded the order it had previously made. To the allegations of enormously large profits earned in the past it replied to the complainants: -

Had the management been as economical then as now, with the large earnings in those days, no doubt substantial reductions could have been made without hardship upon the stockholders; but this matter can be dealt with only upon conditions as they exist to-day. ${ }^{8}$

$17 / 217 \mathrm{ff}$.

Ibid., p. 218.

I Ibid., p. 221 ff. 
The last clause of this sentence is significant and is in line with its employment of physical valuation as measure of capital value. A later statement to the effect that in "dealing with this feature of the case the Board will be understood as referring to the actual money that was honestly invested" indicates, however, that the Board has not been seized as yet with the difficulties of the problem of valuation. The general intention of the Board, apart from this haziness in respect to the actual capital it intends to protect, is manifest. The general statement could not be more clearly put than in the words of the opinion:-

It is of great importance that not only the people of the Yukon, but for that matter that the people everywhere, should be protected from extortionate or unreasonable transportation charges; but to my mind it is of equal importance that the capital invested in transportation companies should be permitted to earn fair and reasonable dividends.... While our duty to interfere and reduce rates in all proper cases is plain, surely it is equally clear that we should not require a reduction where the effect would be to prevent the investment earning a fair return.

It might be argued that this holding arising out of the conditions surrounding a small and unimportant line constructed under great engineering difficulties can scarcely give a safe lead as to the general policy of the Board. But it is to be recalled that the history of Canadian railways shows that of the three transcontinental lines which are a part of the Canadian situation, only one has got beyond that stage of development, where it is independent of Government assistance. Moreover, all Canadian roads, for a considerable period, will have to find much capital, if they are going to keep pace with the demands for transportation facilities caused by the development of Canada. Even more significant, therefore, is the Board's attitude revealed in the decision handed down in April, 1914, in 
the Western Rates Case, ${ }^{1}$ where this phase of the Canadian situation becomes of great importance. In this case a general attack was made upon Western Canadian freight rate levels as being not only discriminatory but excessive. A part of the problem was to determine whether one of the three lines affected "should be taken as controlling the rate question" for "rates based upon the Canadian Pacific's power to stand reductions would inevitably bankrupt not only both the Canadian Northern and the Grand Trunk Pacific, but for the future preserve the western provinces to that company in so far as any new companies or new lines were concerned." 2 The opinion continues:-

The whole question is or should be what rates are fair? In considering this question of course, surpluses earned by past operations may be evidence to the facts that the rates under which they were earned were exorbitant. Any industrial enterprise has the right to a reasonable surplus over and above its fixed charges and dividends. A railway is also entitled to a reasonable surplus.... To my mind it is quite impossible for the Board to deal with rates in the west on the hypothesis that the Canadian Pacific is the only railway that should be taken into consideration.

The Board rejected the contention that political expediency had caused the authorization of certain lines and that therefore they might reasonably be ignored in ordering a reduction of rates upon the stronger lines:-

Nothing could be more fatal to the continued usefulness of this tribunal than for it to attempt to consider whether or not acts of parliament were passed for political expediency, even if it had, instead of lacking the jurisdiction to do so.

Referring specifically to the Grand Trunk Pacific, the Board declared that the very worst service that it could do would be to order such a scale of rates as would effec-

1 The Board of Railway Commissioners for Canada, File No. 18755, Judgment.

Ibid., p. 34 ff. 
tually prevent the fruition of the project and condemn it to insolvency before the line as whole was actually constructed. "The question for us to decide," it said, "is what rates are fair irrespective of how much any company is worth or is not worth," and stated that "no effect is given to the "lame duck' argument that we have heard so much about during the inquiry, on the one hand, nor to shareholders' reserves on the other." If further evidence is required that the Board considers a fair return on capital invested, the true test of reasonableness, it is found in the following statement: -

The position of counsel for the railways reduced to its logical conclusion, is, on the other hand, that the rates must be based on the returns of the weakest line. I am of the opinion that neither position is correct, but that rates should be considered having regard to the traffic necessities of western Canada and a fair return to the carrier apart entirely from any question of reserves of the company on the one hand or liabilities of the company on the other. ${ }^{1}$

While the Board did not make a physical valuation of the three lines affected, it is manifest that the trend of the decisions points in that direction. There appears to be good reason why the Board did not here follow its practice in The Dawson Board of Trade vs. The White Pass \& Yukon Railway Case. It pointed out that neither the Grand Trunk Pacific nor the Canadian Northern was complete. ${ }^{2}$ Obviously a physical valuation of a line under construction would not afford sufficient data of value to warrant the expense. In the event the Board ordered certain reductions, refusing to make controlling the lack of adequate returns to the Grand Trunk Pacific and Canadian Northern because they both were still in the construction stage, and, on the other hand, refusing to take

1 The Board of Railway Commissioners for Canada, File No. 18755, Judgment, p. 34.

2 Ibid., p. 9 \&. 
as a measure the earnings of the Canadian Pacific. The decision is, therefore, not as clear-cut as the supporting opinion, but is important, as it indicates the ultimate disposition that the Board will likely make of the Western rates situation should the question be raised again when the three transcontinental lines are all actually in operation. That the question will be raised again seems probable if the transcontinental lines continue to be operated under private ownership.

The larger implication of these decisions is clearly that the Board of Railway Commissioners will not make an order that will imperil capital funds actually invested in the transportation systems of Canada. The fact that, when such an order was inadvertently launched against the White Pass \& Yukon Railway, it was promptly rescinded upon the discovery of what its effects would be, shows the temper of the Board. Indeed, the history of that case gives warrant for the belief that if the order which eventually did issue in the Western Rates Case, calling for certain reductions, should appear from its results to be subversive of that principle, then it will be rescinded. The supporting opinion would justify such a conclusion. Moreover, the statement that "the Board is of the view that the serious drop in railway earnings that the past has shown is not of a permanent condition," 1 indicates that the order has been based on the idea of a revival of prosperity. This is a predication that events may falsify. Should railway earnings continue to shrink logically the Board would be compelled to sanction renewed increases. But we may naturally expect before such an action should take place, on the analogy of the Board's procedure in the earlier case, that it would make a careful appraisal of the physical value of the lines in question as the basis of its determinations.

1 The Board of Railway Commissioners for Canada, File No. 18755, Judgment, p. 93. 
Incidentally it may be noted the Board does not presume to deal with the wisdom or unwisdom of the lines in question being built. Replying to urgent appeals to the Board that Saskatchewan and Alberta should "not be compelled to build a second bridge around Lake Superior and pay the piper and be bled through the nose for its construction and operation," the Chief Commissioner said that they "never should have been addressed to the Board." The Board had had nothing to do with building either the National Transcontinental or the Canadian Northern around Lake Superior or anywhere else. The Board, instead of sitting in review on acts of Parliament, was governed by them. Sound as this view may be, problems appear. A road once laid out and built on other lines than those of economy and efficiency in the public interest cannot possibly serve the country and maintain its solvency on rates which represent a fair return on the service rendered. This is the condition from which the West suffers. If a fair return, based on a physical valuation, be accepted as the basis of transportation rates unnecessary lines once built become a burden upon the country at large. Under the rulings of the Board there is no relief. Relief can only come from Parliament, the body primarily responsible for the existence of the roads.

The importance of the Western Rates Case cannot be denied. Not only was it before the Board for a considerable period of time, but it touched a multitude of interests and engaged the attention of an array of counsel not often surpassed. A score of barristers of the first rank represented the Dominion Government, the Provinces of Alberta, Saskatchewan and British Columbia, the cities of Winnipeg and St. Boniface, and the railway companies. Among other associations and boards of trade that appeared before the Board of Commissioners or submitted representations, were the United Farmers of Alberta, the Canadian Manufacturers' Association, and the boards of 
trade of sixteen cities. The decision was written by the Chief Commissioner and unanimously concurred in by the other four Commissioners who sat on the case. In view of these facts we may safely conclude that the judgment represents the considered and mature policy of the Board.

While the general principle of fair return upon capital has been affirmed and color has been given to the conclusion that the basis of capitalization would be the physical value of the road in question, some collateral problems attach to the latter feature of the holding. It is evident that if the Board in any case felt forced to make a physical valuation it might arrive at an estimate of value far below or above that represented by the capital invested in the stocks and bonds. The estimate would carry with it a considerable weight of presumption as to its fairness. The natural supposition would be that the Board, having turned to physical valuation as its measure of capital actually invested, would order rates in accordance therewith even if it meant a drastic reduction in the returns to railway securities. Naturally the Board did not intimate what it would do under these circumstances. In the White Pass \& Yukon Railway Case such a physical valuation was made, but it was not used, as revenues had declined below a fair return on that basis. ${ }^{1}$ In the Western Rates Case the issue was not considered. The complainants made a statistical presentation in connection with the Canadian Pacific, but failed to include either the Canadian Northern or the Grand Trunk Pacific. This only dealt with the finances of the company. The Chief Commissioner warned them, "with reference to the inquiry into the financial standing of the companies, it seems to me that if one is investigated that they should all be investigated." In both cases, however, the Board has suggested that if there were evidence of stock-watering, securities would be scaled down. In the earlier instance it said, "if it were apparent that the

$17 / 282$. 
stock had been improperly inflated there would be no difficulty in protecting the stockholders to the extent of the actual investment," while in the Western Rates Case it declared that it "would be entirely unfair to the shipper if he were compelled to pay rates whic' were based either on the amount of capital stock, the bond issue or other liabilities of the company, a portion of which on the one hand may never have been applied in supplying the transportation system in respect of which the rate was made, or which on the other hand, may represent in part merely a fictitious value."

The trend of these remarks is quite unequivocal and in the direction of physical valuation. The Board, however, did not say that a hiatus between outstanding securities at par value and the results of a physical valuation would create a presumption of fictitious values. This particular bridge was not crossed. Indeed, coupled with these statements regarding physical valuation there are others that seemed to indicate that while the Board spoke of physical valuation it contemplated producing results that hinged on a recognition to some degree of commercial valuation. In the White Pass \& Yukon Railway Case the Board referred to the danger of "shaking the faith of the investing public in Canadian securities," and emphasized the fact that nothing must be done that would tend to check the inflow of foreign capital: -

Railway construction in Canada depends entirely upon outside capital; thousands of millions must be borrowed within the next generation or two. We have in Canada less than 30,000 miles of railway as against more than 250,000 miles in the United States. Within fifty years Canada will require a greater railway mileage than now exists in the United States; the money for the construction of this, must for many years at least, largely come from abroad, and how long would these investments continue if it were known that their earning power might at any moment be terminated by the intervention of this Board? ${ }^{1}$ 
As a matter of fact the condition of the White Pass \& Yukon Railway presented a better opportunity for physical valuation than the transcontinental situation involved in the Western Rates Case. The White Pass \& Yukon Railway is undisturbed by rivals in handling traffic. If, however, two more railways were built paralleling the White Pass \& Yukon Railway, and it were decided that rates must be raised to such a height that all three might receive a fair return on the actual capital invested, as indicated by a physical valuation, then the case would be similar. The Board has indicated that it is not prepared to protect rates based on "merely a fictitious value." The crux of the problem is, shall rates be paid on capital that has been actually spent, though unwisely or unnecessarily in the duplication of lines or branches? Must Canada pay dividends on foreign capital invested in it regardless of the wisdom or economy manifested in the investment lest the flow of foreign capital cease? The vital necessity of a service surely cannot justify, even in the broad sense, its wasteful performance.

The almost hysterical solicitude expressed for the protection of dividends, that the opinion in the White Pass \& Yukon case revealed, certainly indicates an attitude not favorable to the solid, unflinching application of physical value as the basis of presumed fair capitalization. This conclusion is confirmed by the practice and opinion of the Board in a late case where it has again wrestled with fundamental considerations. A judgment was handed down in 1916 upon the application of the telegraph companies for approval of their tolls within the territory west of Sudbury, Ontario, and for transcontinental business. ${ }^{1}$ The question in one form or another was before the Board for four years, but decision was delayed on account of the war. While not dealing with freight rates the problem, as was pointed out in the judgment, is essentially similar: - 
The situation which is presented is substantially on all fours with that dealt with in the Western Rates investigation. There, the Board had to deal with an old established railway, the Canadian Pacific, doing business on a large scale; with a newer railway, the Canadian Northern, which was yet in the construction period and whose traffic was in process of development; and with the Grand Trunk Pacific, a road which was still in the construction period and whose traffic was less developed than that of the Canadian Northern. In the present application, the Canadian Pacific has a developed business and a through system. The Canadian Northern has, since the hearing, been linked up with the Great North Western through an operating arrangement. The Grand Trunk Pacific Telegraph Company is in a development situation and has but recently put in tariffs covering the territory from points adjacent to the city of Quebec to Prince Rupert. $^{1}$

Proceeding upon the basis that "all telegraph business must give its proper contribution to the maintenance, depreciation and interest on the necessary plant investment," the Board reviewed carefully valuations made of their lines by the companies involved. A check was made of the figures of the Canadian Pacific Railway by the Board's electrical engineer, who based his calculations upon a section of line between Vaudreuil and Ottawa. Comparisons were also made with the cost of the Government telegraph system in Nova Scotia. Checking these figures out as against the total valuation given by the Canadian Pacific Railway Company, the Board reckoned that it would mean an approximate reduction of seven per cent in the case of that company. In making the computation cost of reproduction was employed rather than original cost. The Canadian Northern stated it was unable to give information as to what the original telegraph line cost and based its estimate upon the cost of renewal work done by the railway company. With respect to the value of the Great North Western system the Board remarked that lapse of years since the initial construction 1 VI J.O.R.R. 29, p. 50. 
appeared to render it impossible to get at original statements of cost.

With this data before it, the Board ruled that "cost of reproduction of a system whose traffic has reached a high point of development is no more necessarily conclusive as to reasonableness than would be cost of reproduction of the system which is least favorably situated in points of traffic so far developed, and which in terms of the Government returns is operating at a deficit." 1

Earnings were also considered and it was similarly held that the matter could not be looked at "either from the standpoint of the most favorably situated company in point of earnings or from the standpoint of the least favorably situated company.... What is necessary to do then is to arrive at a reasonable adjustment of rates having regard to the traffic offering and probable expansion thereof, as well as the question of a fair return." The final result of the Board's investigation was the promulgation of an amended tariff of maximum tolls based on the transcontinental toll of $\$ 1.00$, which was sustained by the Board as a reasonable rate. The local zone rate of 25 cents was not disturbed, not being really in question, though the Great North Western submitted some evidence bearing on the contention that the rate was unreasonably low. The effect of the judgment was to reduce the rates of the zones to a parity so that any question of discrimination between zone and zone would disappear.

While the result of the investigation tends to confirm the conclusion already set forth that the Board will protect, in so far as rates are in question fair capital investment, the decision illustrates an attempt to secure a definite valuation of the telegraph lines affected on the basis of reproduction cost. It has thus gone a step farther in dealing with the problem of determining what is fair value. Of course, in this instance, the Board could hardly

1 VI J.O.R.R. 29, p. 50. 
do otherwise; the telegraph companies are very much tangled up with the railway lines. The Canadian Northern, for example, stated that "the stock and bond issue did not in any way represent the actual cost of the line; the stock and bond issue simply amounted to an arbitrary arrangement between the railway, the telegraph company, and the contractors." ${ }^{1}$ Moreover, at first the telegraph lines were used for railway service and "the commercial use is, so to speak, a by-product." Only as business develops are wires put in for commercial services. The problem thus arises of computing the cost of reproduction of the whole service and then of apportioning it on the basis of the percentage of mileage of commercial telegraph wires to the whole. Equally significant is its insistence upon fair rates being arrived at by an "adjustment" between "traffic offering and probable expansion thereof" and "fair return." Thus, in this instance, as in previous instances, while the Board has employed valuation data as one of the bases of judgment, it has also been affected, when it has come to decision, by commercial considerations. The same attitude has recurred in less extreme form in other cases. ${ }^{2}$ We may therefore conclude that where an issue between physical and commercial data as the basis of valuation arises, it will be settled in the "British spirit of non-logical compromise" rather than by the triumph of one or the other method.

So far we have discussed the merits of physical valuation on the assumption that if it were applied the result would be that it would make for a lower total valuation than outstanding securities. This does not necessarily follow. There is another possibility. In the case of the Canadian Pacific Railway it is quite possible that the

1 VI J.O.R.R. 29, p. 46.

2 Cp. The British Columbia News Co., Limited: "The right to a reasonable profit to the transportation agency as well must be recognized." $7 / 285$. 
valuation would reveal assets in excess of its outstanding securities. The Board has said that: -

"Should a company not distribute profits earned under legal tariffs, those profits, nevertheless, belong to the shareholders, and it would be equally unfair if such undisturbed profits were taken as a return of capital to the shareholders for the purpose of justifying a rate otherwise indefensible." 1

The danger in respect to the Canadian Pacific Railway is this: It will be remembered that when the Canadian Pacific Railway Company received its charter a clause provided that when dividends exceeded ten per cent per annum reduction in rates must take place. Such a clause put a premium upon the investment of earnings in the physical assets of the company. There is good reason to believe that the Canadian Pacific has followed this plan, and when larger dividends than ten per cent might have been paid, rather than to incur thereby rate reductions, it has expended the funds nominally in replacements and betterments. Hence, physical valuation applied to the Canadian Pacific might easily validate any secret reserve stored in its assets, and thus earnings would be capitalized with corresponding disadvantage to the shipper and public generally. Indirectly such a course would set the seal of approval upon a policy that in effect defeated the only safeguard to the public contained in the charter granted to the builders of the Pacific Railway.

Moreover, there is the possibility that the two methods might be played off against each other; that is, the application of the method of physical valuation might be employed where lines have been unwisely or uneconomically located, and commercial valuation might be allowed to contral where these circumstances are absent. It rests with the Board to prevent such an outcome by the exer-

1 File No. 18755, Judgment, p. 35. Cp. “As a matter of public policy railway rátes should be rates of such a character as to attract investment and to render railway securities marketable." Ibid., p. 27. 
cise of vigilance and good judgment. There are indications that it is alert to this danger. In the Eastern Rates Case ${ }^{1}$ objection was made to the Grand Trunk's presentation of capital account on the ground that it included deductions made because of its Chicago connection, the Chicago \& Grand Trunk Railway Company. It was contended that so far as Canadian rates were concerned they should be considered on their own basis apart from losses of the part of the system in the United States. With respect to its Chicago connection, the Grand Trunk submitted that it had acquired the road when the latter had been sold under foreclosure and that it had secured authorization from the Parliament of Canada. Strictly construing the grant of power the Board declared: -

"Any question which might arise as to the power of the company to make such investment as far as Canadian authority is concerned, is set at rest by the Government's action, confirmed as it is by Parliament. The matter, however, is not carried further. Obligation to construct or purchase, statutory or otherwise, there is none. Certainly the result of the legislation and the agreement is not to render the Canadian shipper subject to the burden of making good losses in United States territory, or to justify higher rates in Canada than those which should obtain had the company's operations been confined to Canada." ${ }^{2}$

To the argument that while the Grand Trunk's lines in the United States did show unsatisfactory results, they nevertheless brought considerable benefit to the parent line, the Board replied that "the manifest qualification must, however, be made and the fact emphasized that while the Grand Trunk proper does benefit by the business it obtains from its American subsidiary lines, that these lines in turn benefit from the connection with the parent company." While it may be allowed that rates on the main line should not be levied at a high level simply to secure funds to acquire or to bolster up weak subsidiary lines, it
1 VI J.O.R.R. 148 ff.
2 Ibid., p. 150. 
must be recognized that the qualification set forth by the Board to the railway's contention is scarcely exact enough. While there undoubtedly is material and mutual benefits derived by the connection of parent and branch line it does not of necessity follow there is an equivalency of benefit, and this is the essence, we take it, of the Grand Trunk's contention. When there is a close relationship, such as exists between the Grand Trunk and its Chicago connection, to endeavor to allow anything to hinge upon the fact that the branch feeder is in the United States is of dubious value. There is some weight in the Grand Trunk's contention that "the Grand Trunk proper would have been in a worse position but for these very feeders." The proper and sound position is, indeed, indicated by the Board, but rather as an afterthought, - rates should not be higher to the Canadian shipper, because of American connections, "than those which should obtain had the company's operations been confined to Canada." $x$

In the Eastern Rates Case a second objection was made to the Grand Trunk's statement on the ground that the same capital covered advances to, or investments in, the Grand Trunk Pacific. Examination disclosed the fact that these advances had not been made out of earnings, but from capital account. The balance due to the Grand Trunk for the Grand Trunk Pacific undertaking December 31, 1915 , amounted to $\$ 27,694,999$. The Board's ruling here is clear, incisive, and wholly satisfactory: "The Board can, of course, give no consideration in the present case to these outside investments as having any bearing on the question of what freight rates ought to be." The investment in the Pacific line is "an investment which freight rates in Eastern Canada should not be called upon to support." It is obvious that the extending of support to the Grand Trunk Pacific differs distinctly from the Grand Trunk sustaining its Chicago connection. The Grand Trunk Pacific is a new line with no direct connection with 
the Grand Trunk Railway and with no very direct influence upon its Eastern traffic. Eastern shippers should not be penalized to enable the Grand Trunk to build or develop this new Western line. The net result of the Board's rulings on these aspects of the Eastern Rates Case is to make it evident that the Board will not allow capitalization accounts to be manipulated to impose rate burdens beyond fair return on capital actually invested in the line involved.

The method followed in this case is instructive. In passing upon the level of Eastern freight rates the Board accepted for primary consideration the Grand Trunk's earnings as a basis of rates. The returns to the Government showed capital charges amounting to $\$ 131,395$ per mile, the Board declined to make this the basis of rates, pointing out after investigation, that it could not be sustained by the standard of any other line either built or projected. The other standards compared were the cost figures per mile of the National Transcontinental, the Intercolonial, the Glen Tay-Agincourt cut-off of the Canadian Pacific, the Canadian Pacific's Sudbury-Toronto line, and the Ontario-Hydro-Electric Commission's estimate of cost per mile of a line between Toronto and London. The Board then calculated the net earnings that would be necessary to yield a fair return on these standards of "six per cent on its capital to provide four per cent for interest charges and two per cent to enable necessary financing and expenditures to be made." 1 The result showed that the Grand Trunk's best earnings fell considerably short of the earnings required on any of the other standards. The general increase asked for was then granted. The case stops short of being a complete application of the principle of fair return based on a cost valuation, because the Board reckoned that on any standard it had before it, the best earnings of the Grand Trunk did not come up to that level. The explanation is that the Eastern Rates Cases

1 VI J.O.R.R., p. 153 ff. 
followed the increase in rates granted by the Interstate Commerce Commission in official classification territory, and Canadian roads could not apply to raise their rates to any extent beyond the American level, if they wished to hold certain traffic.

In other instances the Board has not felt it incumbent to carry the investigation and discussion of valuation back to fundamental considerations. Principles are not stated as uncompromisingly and as definitely as in the cases selected for examination. The same ideas essentially, however, appear to be assumed as underlying postulata. The same desire not unduly to curtail railway earnings is disclosed. The 1912 investigation into express rates is a case in point, it being remembered that the express business of Canada is carried on typically by the railroads through the agency of subsidiary companies. In the autumn of 1912 the Board on its own motion initiated an investigation into express rates in Eastern and Western Canada, ${ }^{1}$ and a j'1dgment followed in April, 1913, a year, it will be noted, before the Western Rates Case. The effect of the Board's previous judgment upon express rates was one of the questions at issue. The president of the Canadian Express Company, a company whose business lay practically all in the East, had asserted that reductions in rates either directly or indirectly made by the Board were making the continued financial success of the company more or less doubtful. Dealing with the admitted fact that the company's profits for the year ending June 30, 1912, had fallen much below former standards, Chief Commissioner Drayton was at pains to show that this fall in profits was mostly due to increased cost of service rather than to reductions ordered by the Board. He pointed out that in the previous inquiry the Board had accepted as reasonable with some exceptions, the predominant scale of charges in use in eastern Canada. Continuing he said:-

$19 / 309$. 
The net results to the Canadian Express Company, that I take as a fair illustration of express conditions in eastern Canada, show that from a net return on the gross revenue of 13.1 per cent, as ascertained by the Board in its former investigation the net return on a much larger turnover to-day has dropped to 6.09 per cent. I do not say that this much smaller figure to-day is to be looked upon or adopted by the Board as only a reasonable compensation but I hesitate to make any drastic order applying to eastern Canada in the face of this increasing ratio of expense, and the proposed introduction of the parcels post.

. Accordingly no general reductions were made in Eastern Canadian express rates. In the earlier inquiry the companies had maintained that the cost of conducting business in the West was greater and the density of traffic less than in the East. This contention was given considerable weight, so that while the basis of the scale for Eastern Canada was not to exceed $\$ 3$ per hundred pounds for 900-1000 mile group, in the West the rating for the prairie section was placed at $\$ 5$ and for the mountain section $\$ 6$. The 1912 investigation took the returns of the Canadian Northern Express Company, which carries on its business almost entirely in the Prairie Provinces, as typical for that section of the country. This company's business for the year ending June 30, 1912, showed a return on its operations of 24.745 per cent. The Board held that the actual results of operation of the earlier order seemed to show that undue weight had been given in the previous judgment to the contention that the cost of service was greater in the West and ordered a reduction in rates in the West of twenty per cent. Thus, in this instance, where the express companies were shown to be in the enjoyment of handsome profits, the Board reduced rates, but where profits were falling, even though they had not fallen below six per cent the Board refused to order reductions lest that decline should continue to be accelerated to an injurious degree.

In this investigation and ruling the computation of the 
ratio of net earnings to gross revenue was the decisive factor in determining fair returns. The propriety of valuations was not considered. Chief Commissioner Drayton expressing the opinion that -

The express business is a matter of railway operation in this country, and the capitalizations and bonded indebtedness of the different express companies have been created under such circumstances as to require no consideration in striking a rate.

The general tenor of the decision is clear. The Board will protect fair investment, but will ignore outstanding securities in determining capital value where there is evidence that they have been issued arbitrarily or without due regard to the magnitude of the enterprise. Similarly the Board refused to permit the Hull Electric Railway to increase its rates in view of large net earnings in proportion to gross earnings. ${ }^{1}$ An affirmative holding occurs in the case of the Dominion Sugar Company vs. Père Marquette Railway, et al. ${ }^{2}$ that "the Board's endeavor, while assisting traffic as much as possible and equalizing rates, should also be directed to maintaining railway revenues in Eastern Canada, where, as matters stand to-day, they are relatively lower than in the West." So in the case of the Western Ontario Municipalities vs. Grand Trunk Railway, et al., the Board refused to order a low rate on gravel for road construction, holding that "in every case traffic moved must be of sufficient volume and the hauls of sufficient length to ensure proper remuneration." 3 In Brown vs. Lake St. John Railway the company had canceled an established commutation rate on tickets. The Board refused to interfere, observing, "the statement of the railway company's financial position shows that it has been operated at a loss for many years. The contention is that

$110 / 339$.

217 C.R.C. 240. (C.R.C., i.e., MacMurchy and Dennison or MacMurchy and Spence, Canadian Railway Cases.)

318 C.R.C. 329. 
the ten trip tickets at the rate at which they have been sold are unremunerative." " From this position it is not a far step to permitting the Edmonton, Dunvegan \& British Columbia Railway ${ }^{2}$ to apply the mountain rate in prairie territory in contravention of the Western Rates Case ruling: -

The only argument for taking the mountain scale as applicable to the railway in question would seem that it needs the money, and that the mountain scale is higher than the prairie scale. The application of the mountain scale as such would not, of course, be justified.

The road pleaded that it wished to secure sufficient revenue at least to pay fixed charges. The Board granted the request temporarily, thus permitting a deviation from their earlier decision on the ground of the financial instability of the petitioning line. Thus, while in all these cases there has been a careful regard for due return upon actual investment, the Board has not faced the more difficult problems of accounting and valuation. Except in the Eastern Rates Case it has not closely scrutinized the actuality of investment. The issues have been disposed of by the shortest route, without recourse to much investigation or consideration of ultimate principles. In so far as the use of ratios of net to gross earnings has been relied upon, it would appear these ratios on the whole have been used uncritically. Nor have the implications of the method been developed. The accounting problems in connection with the determination of net earnings have not been fully resolved. The principle of fair return has been confirmed, but has not been worked out with clearness or thoroughness. ${ }^{3}$

118 C.R.C. 342.

$210 / 341$.

3 Cp. "In the Eastern Rates Case, the general rate structure was dealt with, and the whole question of railway finances and requirements of the different lines were given most careful consideration by the Board." VI J.O.R.R. 380. 
$\S 3$. In the leading cases under consideration the attack was upon general levels of rates. In The Dawson Board of Trade vs. The White Pass \& Yukon Railway Case, as the whole traffic of the road was under review it was comparatively easy to arrive at the probable effect of a reduction in rates. To a lesser degree this was true also in the Western and Eastern Rates Cases. While the scope was not so extensive large traffic areas were under consideration and it was possible with some success to attempt to segregate operating costs, and to compute the net effects of reductions or increases on traffic. It is manifestly quite a different proposition to determine the result of reducing the rate on a single article on the general revenues of the company. Yet the characteristic case where excessive tolls have been alleged involves this difficulty, for a complaint of this nature has generally arisen because a rate has been advanced. The invariable defense of the carrier company, responsible for the increase, is that circumstances show that the commodity in question is not carrying its due share of the costs of transportation. The appeal to circumstances introduces the application of those secondary tests of reasonableness upon which the Board, through the absolute impossibility of segregating the costs of transporting a single article of commerce, has come to rely.

As a presumption of reasonableness attaches to an established rate, not conclusive but yet necessary to rebut, the justification of an increased rate most naturally lies along the line of showing a change in circumstances from that under which the original rate was made. The convenience of this method is apparent at once, for, without being able to trace all the costs of carrying a certain article, it may readily be shown that conditions have changed so that whatever it may have cost in the past it now relatively costs more. The Board has admitted the reasonableness of this deduction and has recognized the legitimacy of increases made under these circumstances. 
Obviously the first question to be considered is the immediacy of the circumstances in which a change is an admissible ground for a change in rates. The Board has in recent decisions widened the field of relevancy to a considerable degree so that its record is a developing rather than a consistent one. It seems best at this time to indicate and work out the implications of its earlier position and leave its later holdings to subsequent notice. In the Pender Cases ${ }^{1}$ the Board held that information as to changed conditions and costs should be as to the particular commodity as to which the rate increase had been made. In Davy vs. The Niagara, St. Catharine \& Toronto Railway Company and The Michigan Central Railway Company, ${ }^{2}$ the first railway "submitted evidence to show that the rate of wages paid its employees had materially increased," and contended that it was justified in raising the rate on wood pulp in order to "maintain the road on a fair financial basis." But it was shown that there was no general increase in rates, the wood pulp tariff seeming to be the only one revised. Pointing this out, the Board ruled that the old rate should be reëstablished. In brief, the Board in these cases refused to accept the proposition that a general increase in costs would justify an isolated increase in rates. Similarly, in Stockton \& Wallinson vs. The Canadian Pacific Railway the Board refused to permit an increase of rates on fruit because conditions were not shown to be changed, and the old rate was not shown to be unprofitable. ${ }^{3}$

On the other hand, in The Canadian Lumbermen's Association vs. The Railways, ${ }^{4}$ the carriers put in voluminous exhibits showing sharp increases in the cost of maintenance and operation of the lines with particular reference to the increased cost of ties and lumber for cars. The Board said, "it is fair to attach some importance to the large increase in the cost of maintaining and operating railways."
$18 / 47$.
$27 / 190$.
$35 / 207$.
$46 / 138$. 
In the eastern part of Canada the railway companies customarily perform certain cartage services and the tolls are under the control of the Board. An advance in rates was upheld on the basis of an increase in the "cost of horses, the cost of wages, and the cost of feed." 1 In this instance it was particularly easy to prove the increased costs that attached to certain traffic. This case may be compared with The Red Mountain Railway Company vs. The Columbia and Western Railway Company, ${ }^{2}$ where the interswitching charge was reduced because the cost of service had been cheapened by the establishment of a new transfer point.

In accepting cost data as evidence of the reasonableness of a rate increase the Board has insisted that they shall be sufficiently complete to indicate a net increase in cost. Thus, in the Proposed Increase in Rates on Hay Shipped from Ontario and Quebec ${ }^{3}$ the Board set the increased cost of railway operations over against an increase in operating economies and refused to sanction the advance. In other cases it has rejected cost data altogether because not sufficiently complete to afford ground for the judgment that there had been a net change in cost conditions.

The Board has also rejected as cost factors, where there has been change, peculiar elements present when the original rate was made. In the Hay Case, just referred to, the railway urged certain peculiarities of the hay traffic, but the Board replied that every one of the characteristics mentioned had been incidental to the traffic for years past. ${ }^{4}$ Nor will it admit the pertinency of a change in conditions that might reasonably be foreseen when the rate was made. When the Canadian Freight Association in 1909 applied for an order to rescind a reduced rate on fruit to certain Western points, ${ }^{5}$ which had been agreed upon as a compromise in the first place, on the ground that the existing rate situation might create demands for rate re-
$8 / 68$.
$25 / 229$.
37/238.
- $7 / 241$.
5 5/245. 
ductions to other points in the West, the Board answered that "the railways had ample opportunity to forecast the conditions now complained of" when the rate was originally adjusted, and refused to disturb it. To a second plea that the rates charged on fruit were relatively unprofitable, supported by a comparison by those charged on lumber, the Board was equally unsympathetic. "Admitting the existence of low earnings on fruit it does not appear that this is pertinent to the argument that rates should be raised. For the comparison between fruit rates and iron rates was as much in point in 1904 as it is now."

While distance in haul is an element in cost it does not lend itself readily to employment in determining whether a rate is reasonable in itself. It has a greater range of usefulness in cases involving discrimination. Indeed, in cases where the question of distance has been raised, in the former category, practically the only notice given to it is to point out the minor position it occupies as a determinable element of cost. In Doolittle \& Wilcox vs. The Grand Trunk and Canadian Pacific Railways ${ }^{1}$ the Board rejected an application to place the rates on quarried stone to Toronto on a mileage basis plus a charge for terminal service. The Board declared:-

The fundamental ground of the application is to have mileage form the sole basis in making these rates. To those who have not had experience in ratemaking the argument that distance must be the principal factor appeals with force; but the history of these cases shows that while it is of course to be considered, yet in many instances it is a minor matter.

This opinion may be compared with a statement in the reply to the application of the Canadian Portland Cement Company for a reduced through rate from Black Rock to Marlbank, - "it is recognized that differences in traffic conditions are in general more important than mere mileage comparisons." 2 The general position here taken indi-
$14 / 244$.
$25 / 238$. 
cates a rather close accord to the railway man's point of view, though when attention is given to cases involving discrimination, it will be noted that distance receives greater consideration. The holdings considered here simply mean that the Board has a low opinion of the element of distance as a factor in disclosing fundamental costs. ${ }^{1}$

Volume of traffic has been recognized by the Board as a valid element in the determination of rates, ${ }^{2}$ but its use has been largely confined to cases touching discrimination and its discussion is reserved.

The position here developed with regard to secondary measures of costs may be termed the Board's earlier position in regard to these factors as indirect tests of a reasonable rate. Under the Board's ruling, that changes in cost must relate directly to the commodity as to which the rate is in issue, it will be noted that it is extremely difficult for a railway to justify an advance on this basis. Where the plea succeeded it was usually with regard to some easily segregable cost such as cartage or switching rather than with respect to transportation proper. In the case of the increase sanctioned in the rates on lumber the nexus between an increase in cost in lumber to the railways, and therefore an increase in the cost of the carriage of lumber, is not traced out and truth to tell appears rather doubtful. The case really comes within the scope of the wider principle enunciated in the International Pulpwood Rates Case, ${ }^{3}$ to which we now turn.

The history of this case can be given in a few words. The railways filed a tariff, taking effect in September, 1912 , to increase the through rates on pulp wood from shipping points in Eastern Canada to manufacturing points in the Eastern States of the Union. The paper manufacturers of New York and a number of Canadian

1 Cp. "For distance to be the common yardstick of reasonableness it must also be the common yardstick of cost." VI J.O.R.R. 38.

2 VI J.O.R.R. 55.

$8 / 271$. 
producers preferred a complaint of which one portion was as follows: -

The continuance of the rate since 1903 is presumptive evidence that the companies have considered them profitable and disproves the contention that the tariff has not borne its proper share of the increased cost of railway operation, and are therefore too low.

In reply the railways claimed that it was quite impossible to segregate the cost of handling this particular traffic, but notwithstanding argued the case on the general issue that the expenses of conducting transportation, following the general tendency, had greatly increased. In addition, they submitted comparisons to show that other rough lumber products were paying a higher rate than pulp wood. While other factors entered into the decision, the force of the general contention was granted. "It has been fairly established," the Board said, "from time to time, that the expense of conducting transportation, following the universal tendency, has increased considerably during the past few years." The recognition of this principle was a most important victory for the railways, which had been arguing the legitimacy of this point of view, ever since the establishment of the Board.

Mr. Commissioner McLean dissented from the view of his colleagues who sat on the case. He pointed out that the Board had hitherto taken the position that general allegations as to increased cost of service were not conclusive as to the reasonableness of a given rate:-

Personally I am of the opinion that the railroads should adduce particular information as to the increase of the particular costs affecting the traffic in question, if increase in cost is to have any adequate weight in justifying the reasonableness of the rate attacked.

In view of the dissenting opinion, and the fact that other elements were a factor in the judgment that sanctioned the 
increase, the value of the case as a precedent might be questioned. But in a subsequent decision the principle that a general increase of costs is a good defense to an advance in a specific rate has been affirmed under circumstances that can leave no doubt as to its significance. The rate on pressed brick from Bradford, Pennsylvania, to Windsor, Ontario, early in 1912, was increased from $\$ 1.60$ a ton to $\$ 2$. A complaint was entered and came to hearing ${ }^{1}$ in April, 1912, before the International Pulpwood Rates Case was adjudicated. Dealing with the increase in so far as the Canadian roads were concerned, the Board pointed out that no evidence had been presented to show that there had been an increase of cost of any kind connected with this traffic that would warrant the advance and disallowed the increase sought. Subsequently leave was obtained for a rehearing and when the case came up for disposition, Mr. Commissioner McLean, who had dissented in the International Rates Case, wrote the opinion and in referring to the effect of that case, said: -

This judgment in effect sets out that not particular cost alone, or conditions peculiar to that particular commodity, but all material conditions and costs, including therewith comparisons of rates, may be given such weight as seems reasonable to the Board. It follows that for this purpose all tariffs on file with the Board, whether referred to in the record or not, are part of the record. The present rehearing must be dealt with in the line of the principles which the above mentioned case has developed.

The Board has thus abandoned the position taken and maintained during the larger part of its history. It is true that this widened basis of judgment does not destroy the value of evidence of the specific nature demanded by the earlier canon when it is available, but it does make it very much easier for the railway companies to justify the advance of individual rates. Evidence of specific changes in 
circumstances are no longer absolutely necessary if an advancing cost curve can be shown.

It is difficult to determine the degree of importance that will ultimately attach to this method of judgment. In the two cases just considered some reliance was placed upon comparisons between the ton mile rate upon similar products. The rates upon rough lumber products were considered in comparison with pulp wood. In the Pressed Bricks Case rates on coal were scrutinized. These comparisons, however, were not the controlling elements in the decisions but were rather appealed to as confirmatory of the reasonableness of the rates fixed upon. The new holding marked the assumption by the Board of a wider discretion in the determination of rate changes.

The importance of this widened basis of decision makes it necessary to give it some consideration. It is obvious that unless there goes with it a wide and careful use of comparison it means a considerable degree of piecemeal revision upwards may be accomplished. This carries the danger of a lack of due regard for equitable relationships between the rates on different classes of traffic. This danger is particularly likely to occur between classes of non-competitive traffic. As to the influence of the decision from the standpoint of economics it makes it easier for the railways to employ their favorite principle of charging what the traffic will bear. It permits this principle to slip in by the back door. This is quite clear. If for any reason an increase of revenue is necessary, instead of a general revision of all rates with due regard to their equitable relation to each other, it permits the railways to select the particular commodities upon which they believe they may easiest saddle the increases. It is possible we have a hint of this in the judgment on import rates delivered shortly after the Eastern Rates decision. The companies desired materially to increase their import rates which were on a relatively low basis. "Treated as 
individual rates," the Board said, "they undoubtedly are low," but ruled that no action should be taken in this case until the effect of the Eastern Rates judgment could be clearly demonstrated. ${ }^{1}$

Moreover, it operates to the disadvantage of the individual complainant who appears before the Board. As against a submission of evidence dealing with the precise commodity the rate for which is in dispute the railways may present an array of general data, which in the nature of the case the complainant could not challenge except at great expense and difficulty. Finally, in so far as it widened the scope of discretion for the Board, by departing from specific evidence, it marked the assumption of more freedom by that body. The Board has rather carefully guarded itself under the new canon from sanctioning isolated increases in rates where the effect might be to create, inadvertently, discrimination. In most instances it has tested the rates by careful comparison with the rates upon articles of a similar nature or by comparisons of car mile earnings, ton mile rates, or cost of service per car. Thus Messrs. Auger \& Son, and the D'Auteuil Lumber Company, of the City of Quebec, objecting to a new tariff providing for increases on pulp wood to Mechanicsville, New York, from the Eastern Townships, failed to gain their case because it was established that pulp wood, on the proposed rate, loading only 20.25 tons per car, coupled with high cost of car service, would give relatively low earnings compared with other tenth-class commodity traffic such as brick and gravel. ${ }^{2}$ In a somewhat similar complaint made by the Lake Superior Paper Company, Ltd., against the Algoma Central \& Hudson Bay Railway, the Board supported the rate set by the railway, basing its judgment on a comparison with rates on pulp wood as set forth in the Eastern Rates Case. ${ }^{3}$ Thus, in both these instances, where it was alleged increases on single commodities were un-

1 VI J.O.R.R. 380.

$211 / 165 \mathrm{ff}$.

s VI J.O.R.R. 396. 
just, although the rate was held reasonable, the determination was based on specific factors.

The Board has recognized that a circumstance in which a change may take place of significance in rate-making is the value of the commodity in question. The Board has not confined itself solely to a consideration of cost data. There are a number of cases which hold that an increase in the value of a commodity is a legitimate reason for an advance in its rate for carriage. In the Lumber Rates case ${ }^{1}$ already referred to, the Board expressed the opinion that the

strongest evidence submitted for the companies in justification of the increased rates on lumber was the very large increase in the value of timber during the last ten years. The value of the commodity hauled is an element that may properly be considered in ratemaking. In general the greater value of the article the greater the rate may be. There are of course, many other elements to be considered in deciding on the reasonableness of a rate, which may in some cases outweigh the elements of increased value of the commodity.

This perhaps is the clearest statement of the Board's view, but the principle has been employed in other cases. A complaint was launched by mine operators at Salmo, British Columbia, that the Nelson \& Fort Sheppard Railway was forcing the complainants to ship their ore at rates based on a valuation of twenty-five dollars per ton. ${ }^{2}$ The operators claimed that their ore was of value lower on the average than twenty-five dollars a ton. The Board ordered additional rates to be put into effect to cover ore shipments of a value of fifteen and twenty dollars a ton, observing, that it did "not appear reasonable to bulk the ore from Salmo under the twenty-five dollar valuation when it is admittedly of much lower value." A change in the classification of tobacco, involving an increase of rates, was disallowed, it being stated, among other reasons, that

$$
{ }^{1} 6 / 141 . \quad 29 / 276 .
$$


the "railways did not present exact information regarding values in justification of their proposed increased rating." 1 An application for the same rate on hardwood flooring as that paid on fir, hemlock, etc., to Vancouver was denied because hardwood flooring was "a more valuable commodity." ${ }^{2}$ In the Davy Case the fact that "pulp had gone down in value $\$ 5.00$ per ton" weighed in the decision against an increase in rates. ${ }^{3}$ On the whole, however, the principle has not received extended use where the reasonableness of a rate in itself was at issue. The failure of value considerations to enter more conspicuously into rate determinations in Canada will be discussed after a survey has been made of its use in cases involving discrimination.
$16 / 221$.
$27 / 254$.
7/190. 


\section{CHAPTER VII}

RATE THEORIES DEVELOPED IN CONNECTION WITH THE CHARGE OF UNJUST DISCRIMINATION

§1. The second main category into which appeals against railroad tolls fall concerns unjust discrimination. Indeed, because of the range of appeal and the magnitude of the issues presented, it might well be placed first in a consideration of railroad rates. But the reasonableness of a rate per se raises a more fundamental question to which the question of discrimination is after all secondary. The latter implies at the outset that the rate under complaint is satisfactory when viewed without regard to its relation to other rates. The former goes to the root of the problem and discusses the basic factor with which the latter begins. Out of deference to this view the reasonableness of rates, in themselves, as a problem of administrative ruling has been considered first.

On the other hand, charges involving discrimination introduce to a greater degree conflicting interests. If we leave out for a moment the general interests of the consumer, which is present in both instances, while a dispute over a rate as reasonable in itself touches two parties, the shipper and the railway, a dispute where discrimination is alleged brings in a third interest, the party to whom the benefits of the alleged discrimination accrue. The discussion of discrimination is mixed up with all the acerbity engendered by rivalry for markets and trade. An unwise decision may nullify the effect of protective legislation, or geographical location, and indeed injuriously disturb the normal industrial organization of a country.

In the first part of this study an effort was made to present the salient characteristics of the transportation situa- 
tion in Canada. The end in view was to prepare for an intelligent appreciation of the trend of the decisions of the Board. In the review of cases concerned with the inherent reasonableness of rates we have noted how public aid and public endorsement of railway lines is reflected in the anxiety of the Board to protect the integrity and stability of these lines, lest Canadian credit be injured and the possibility of building other lines in the future be thereby curtailed. It is, however, particularly with regard to judgments in respect to discrimination that the value of the preliminary study should appear. The historical background, the geographic factor, these, in many instances, condition the holding of the Board. These are the factors that provide permanent and intractable elements in the resolution of rate problems, especially in cases of alleged discrimination.

It will be recalled that the development of charter and statutory control was traced down to its present position. There it was pointed out that the dangers of unjust discrimination were early perceived. In charters and general acts unjust discrimination was specifically legislated against, and this with increasing inclusiveness and minuteness as the evils were more clearly discerned. Nevertheless, it was recognized that no mechanical rule of equality of tolls could cover all cases, a principle that the Board early elaborated in language of its own:-

It is not in the nature of things possible to secure anything like absolute equality of treatment to all persons who use the railways, or even like treatment to all who are using the same railway. The general public have theoretically a right to complain if the people in oue or more sections of the country served by a particular railway are given a better service than the people of other sections; but with every desire on the part of the railway company to accord equally fair treatment to all patrons over its entire system, circumstances and conditions are too controlling, oftentimes, to be resisted or overcome. ${ }^{1}$ 
Accordingly the requirements have been deemed to be satisfied when traffic moving under "substantially similar circumstances and conditions" bears the same rate, and upon the Board devolves the duty of determining what constitutes these "circumstances and conditions." Essentially problems of discrimination, which have come within the purview of the Board, have turned on differences in geographical location, in the traffic conditions under which freight is hauled or in the nature of the commodity itself. This division will serve our purpose to bring forward in orderly manner the holdings of the Board.

$\S 2$. From the standpoint of freight movement geographical location is one of the most important influences which confront the railway traffic manager. He has to make a study of the peculiar possibilities and necessities of each traffic center, and largely on the wisdom of his decisions hinges much of the prosperity of his railway. Obviously geographical location may tend to affect freight rates from a given center in certain typical ways. The city or town or district in question may have the advantage of being served by two or more competing lines of the same nature. Thus certain points may be connected by lines of unequal length and the efforts of the more circuitous route to share in the traffic, while beneficial to the place concerned, raises problems of discrimination for other traffic centers on its line. Again, there may be communication between two centers by transportation agencies of a different nature, that is, by water and by rail or by a combination of the two. Finally, a variant of these conditions occurs when the favorably located center is a receiving point rather than a shipping point, and low rates to it from one direction provoke a demand for similar accommodation from other points; that is, where there is competition for markets.

The interaction of these conditions produces some of the knottiest problems in rate determination that come be- 
fore the Board. Not infrequently all are involved in a single decision or group of related decisions. Thus the cases with which the Board has had to deal relating to oil and sugar rates between Winnipeg and the western Ontario peninsula has brought up the relationship of water and rail rates and competing routes, with pendent problems of the competition of markets arising from the movement of oil from Kansas and sugar from British Columbia.

Two principles may be premised in the Board's disposition of these cases. The statute explicitly provides for the recognition of competing points and competing tariffs, so that the Board is relieved from finding a basis for discriminative treatment of competitive rates in the principles of joint costs or considerations of public policy. In addition to this it has repeatedly held that it is at the discretion of a carrier whether it shall or shall not meet a competitive rate. In this, of course, it has but followed the lead of American and English precedents. In the British Columbia Sugar Refining Company vs. The Père Marquette Railway Company, the counsel for the Canadian Pacific Railway, in his argument said: -

It may be quite true, as pointed out by the complainants, that a reduction has been made which enables the competitors of the complainants in Wallaceburg to have the advantage of lower rates to the three points mentioned than they obtained formerly, but that is not a condition for which the Canadian Pacific Railway Company is at all responsible. If a competing company wishes to make a substantial reduction in rates for the purpose of giving advantage to a refinery situated on its own line, it is, I presume, at liberty to do so, but by doing so it cannot compel other railway companies on whose lines competing refineries are situated, to make similar reductions in their rates to common points.

This argument by the railroads, which puts their case in a nutshell, was accepted and quoted by the Board in its judgment, and made its own position:

A railway must of necessity be given considerable discretion in regard to meeting competition, and the forms of competition to 
which it is subjected are varied. It is patent that if a railway establishes a rate between Toronto and Winnipeg, it is entirely within the discretion of another railway connecting such points, whether it shall or shall not meet this rate. If the second railroad should decide not to meet this rate, this does not of itself give the Board jurisdiction to order it to meet the lower rate.

Thus the principle of competition, explicitly recognized and guarded, cuts across the power of the Board to remedy all grievances arising from discriminative treatment. ${ }^{1}$

Of the various typical forms of geographical advantage in Canada undoubtedly the most important is the presence of water competition. Reference at an earlier stage of the study has been made to the extensive system of waterways that Canada has built up. It was shown that while the construction and improvement of the waterways was undertaken with a relatively narrow and immediate end in view, the upshot is that Eastern Canada is furrowed with improved waterways capable of carrying freight traffic. The time is now ripe to consider the effect of this outcome upon railway rates of carriage.

In railroad circles the pervasive power of water competition has long been recognized, but it is doubtful, apart from special students of the problem, if the importance of this factor has been generally known. The findings of the Board in the Western Rates Case are therefore of particular interest for the light that they throw upon the influence of the waterways upon railway-rate levels. In this case which covered a variety of grievances, the nub of the complaint was that the East enjoyed lower rate levels than the West. This necessitated a careful investigation of the effects of competition by water carriers in modifying rate levels for

$15 / 280$. Cp. "The Board has time and again recognized that it is within the discretion of a railway to meet the competition of short line mileage. The discretion of a railway in regard to meeting water competition has been so often emphasized by the railway regulative bodies of Canada, England and the United States, that mention of it is alone suffcient." Ibid. 
carriage by rail. Much evidence was presented and the conclusion of the Board is contained in the judgment. It is sufficiently important to warrant insertion here:-

In the matter of water competition there can be no doubt at all as to the efficiency of the waterways spread through Eastern Canada from its easterly coast and terminating with the western limit of the most westerly division of the East at Port Arthur and Fort William. ${ }^{1}$

While with respect to the Maritime Provinces it declared:

The rates in the maritime provinces are low, not only as a result of water competition, but also as a result of rates obtaining on the Intercolonial, whose operations have largely resulted in deficits.

This conclusion, a finding of fact, is repeated at several points in the judgment. With respect to traffic in certain sections of Ontario, where it was argued that rates could not be affected by water competition, cities such as St. Thomas and Stratford, the Board replied that the issue had been presented "in the large," that a comparatively small part of the traffic in Eastern territory was unaffected which was entirely lost in the general aggregate of traffic moving under water-compelled rates. In dismissing the charge of unjust discrimination on this basis the Board said: -

On economic principles special rates to competitive points or in competitive zones, as already noted, have been justified. They have been practically always regarded as proper in principle and probably must apply for all time in the future, at least until such time as railways cease to be operated for profit and are carried on as a matter of governmental operation irrespective entirely either of cost or of value of services, or the necessity of obtaining business. ${ }^{2}$

The economic justification to which the above excerpt alludes is simply an example of the workings of the principle of joint and secondary costs. The railways have to meet annually large payments which will accrue whether traffic is carried or not. Now any freight that will yield
1 File 18755, Judgment, p. 17 ff.
2 Ibid., p. 23. 
returns above the direct out-of-pocket costs of handling it will be profitable. The surplus above out-of-pocket costs will be available to meet the indirect costs. The railways claimed that while water competition in the East forced rates below what they could afford to carry freight in general for, yet the rates obtained exceeded direct out-ofpocket costs and the freight was therefore desirable to handle. The Board allowed this position, and found that, while discrimination existed as between the rates charged east and west of Port Arthur, that discrimination was "neither undue or unjust."

The Board does not deny the desirability of rates in Eastern Canada and in Western Canada approaching the same level. Thus in the Eastern Rates Case, in granting increases in Eastern Canada following the five per cent advance authorized by the Interstate Commerce Commission, it declared: -

There is no doubt but what the Act requires and the general public interest of the country as a whole demands, that, if practicable, eastern rates should be advanced so that the different schedules may more nearly approach a parity. ${ }^{1}$

Further, the Board has recognized that as a result of water competition much traffic is carried at a rate that yields very little profit. Discussing a 13.1 cent rate from New London, Connecticut, to Toronto on Pacific Coast lumber taking the Panama Canal route, the Board pointed out that this was simply the rail proportion of a combined ocean and rail rate in competition with the overland rate of sixty-seven cents, adding:-

It must be clear to all that if the low proportionals accruing to the Canadian carriers on international traffic, or even the entire rate on much of the transcontinental business as it stands to-day were to be regarded as fair measures in the fixing of local rates, it would only remain to conjecture how long the companies might continue solvent. ${ }^{2}$ 
The Western Rates judgment is especially important because of the area affected, - practically the whole of Canada, - but is in keeping with earlier decisions. Indeed, wherever discrimination has been charged and it could be shown that the rate against which it was leveled had been compelled by water competition or was itself levied upon a broken water-and-rail route, the Board has invariably recognized that there was thereby created a dissimilarity of circumstance which forbade relief under the clause against discrimination. Thus, in The Canadian Oil Companies, Limited, ${ }^{1}$ complaint of discrimination in the oil rate from Petrolia, Ontario, to Winnipeg, a comparison was instituted with the rate paid by the Imperial Oil Company from Sarnia to the same market. It was shown that the latter company shipped oil by tank vessels from Sarnia to Fort William at a very low rate, which became a part of the total rate to Winnipeg. The judgment Commissioner said: -

I am unable to see why the low rate basis afforded by water transportation in the case of produce not conveyed by the railway should be used as an argument for a reduction in the rate of the produce carried by the railway.... Nor is the low rate basis by water an evidence of the unreasonableness of the rail rate.

Characterizing this portion of the argument as being "based on an erroneous construction of the policy to be adopted in the matter of water transportation," he held it must therefore fail. The decision was concurred in by the other Commissioners who sat on the case. A similar position may be cited in the British Columbia Interior Rates Case: ${ }^{2}$ -

The low rates to the coast are made necessary in order to enable the railway companies to obtain traffic in competition with ocean carriers. Such a practice is distinctly authorized by the Railway Act. 
The rates on water-borne traffic do not themselves come within the scope of the Commission's powers, except where steamer lines run from one part of Canada to another under agreement with a railroad or are owned by a railway. It is of interest, however, to note the Board's attitude as to the necessity of rate regulation in the case of traffic moving by water. This may be gathered in the opinion handed down on The Blind River Board of Trade Case which involved the rates on lake-borne traffic of the Grand Trunk as between charges to Blind River and Sault Ste. Marie: -

It is safe to say that water transportation has been recognized as more highly competitive than railway transportation, and it is on this account parliament has not deemed it necessary to intervene here to hold the balance true between the shipper and the transportation agency. There has also been reliance on water transportation as a regulative factor. ${ }^{1}$

Finally, the general scope of the railways' discretion in meeting a water-competition situation is well stated in a decision permitting adjustments following the opening of the Panama Canal. The operation of the canal caused considerable dislocation of the general traffic on transcontinental business. The Eastern boards of trade and railways were in agreement as to the reality of competition. In authorizing a tariff low enough to permit traffic to move by rail the Board declared:-

Whether such rates are or are not put in is a matter entirely for the railways. They cannot be ordered by the Board. If, however, the railways put such rates into effect, they will not be considered as rates reflecting in any degree the measure of the reasonableness of the service, ... or afford the slightest index as to the reasonableness of rates charged between points not affected by Panama competition. ${ }^{2}$

It does not require much reflection to grasp the significance of these findings. They go far to establish the

$$
115 \text { C.R.C. 147. } 211 / 184 .
$$


truth of the contention put forward earlier that the natural features of the Canadian situation tend to reduce real power of a regulative board of commissioners to fairly narrow limits. The findings of fact in numerous cases reveal the preponderating influence of water competition on railway rates in the Eastern Provinces and the Board's lack of power to control this preponderatingly influential factor. Thus, in five out of nine Provinces (adding British Columbia, six) conditions that sharply limit the actual influence of the Board exist as permanent elements in the situation. The economic significance of this fact is undeniable. If water competition is the real arbiter of rates, the real force that shapes them, in these Provinces, and the findings of fact say so, then the Board, however lavishly endowed with legislative sanction, is after all secondary and ancillary. It may have great practical usefulness in other fields of its labor, but here it is "cabin'd, cribbed, and confined" by the force of circumstances.

If the effect of water competition, touching the transportation situation at a great many points, is to make competition master of the situation, it is proper to inquire its effects upon the industrial organization of the country. Obviously it takes out of the hands of the Board the power of control over harmonious development by rate adjustments. It might be claimed that all this means is that industries which locate beyond localities of special natural advantage cannot have their mistakes remedied by the Board. But it does not necessarily guarantee fair value to natural advantages of location. It does not leave the way clear to natural centers for the retention of advantages due to situation, and the effect is less certain where a district is still in the developing stage industrially. For there resides with the railways the discretion as to whether or not they shall meet water competition. The principle that a carrier may neglect or meet the competition of a rival 
carrier has been affirmed repeatedly by the Board and will be more fully discussed later. It is pertinent to note here, though, that this applies equally to the competition of rival carriers by water. Thus, when the railway companies decided to neglect the local water competition for lumber carriage in the Ottawa Valley and refused to reëstablish, in April, 1914, the tolls of the preceding season, they were sustained by the Board. ${ }^{1}$ The most explicit ruling is to be found in The Blind River Board of Trade vs. The Grand Trunk, Canadian Pacific Railways, Northern Navigation and Dominion Transportation Companies. ${ }^{2}$ In this case it was complained that the companies were discriminating against the towns on the north shore of Lake Huron as compared with Sault Ste. Marie. It was shown that Blind River was off a line of all-water competition that prevailed at Sault Ste. Marie. The Board, declaring that the railways could cancel a low rate that had previously applied, "when water competition becomes less effective, or when the railway thinks it has become less effective, or even when the railway no longer desires to meet it," dismissed the complaint. Thus the advantages that may be potential in a given district may or may not come to realization or be checked at the discretion of the railways. By a shrewd exercise of discretion the railway lines may by very low rates discourage water competition, and, with its decline, again exercising discretion, reëstablish former rates upon a non-competitive basis.

The Board has developed its ruling so that as between points in a given district, even if there is competition at both points, there is little relief against discriminative treatment. While, perhaps, the railways cannot elect to meet water competition at one point and refuse under substantially similar conditions to meet it at another point, this is most difficult to establish. ${ }^{3}$ Thus, in the complaint

117 C.R.C. 102.

$29 / 261$.

$3 \mathrm{Cp}$. "Of course if the railway company, was performing a similar ser- 
of C. A. Bowlby and others against excessive freight rates on the Halifax \& South Western Railway to Medway, the Board found that there was water competition at Medway and that formerly the railway met this competition, but had decided not to make rates to meet it. "The only point at issue," the Board said, "is whether the fact of the railway, having met water competition at any earlier period, puts the burden upon it to meet competition now." On the ground that the railway had the privilege of exercising its own choice in the matter the application for relief was denied. With reference to the evidence showing that a lower rate basis existed from Halifax to Liverpool, a point nine miles farther distant from Medway, the Board held that "the fact that it has met the competition at Liverpool does not place on it any obligation to meet the competition at Medway Station." 1 In this instance it was complained that the Liverpool merchants and Medway merchants competed in common territory, so one would gather that the effect of the judgment would be to put Medway merchants at a disadvantage as compared with their more favored Liverpool competitors. Similarly, in the complaint of the Nanaimo Board of Trade against a proposed new Canadian Pacific Railway tariff eliminating Nanaimo as a terminal freight-rate point, the Chief Commissioner said, "Nanaimo for many years has had the benefit of coast terminal rates. This benefit has been taken from it." Admitting inconvenience and sometimes real hardship in such rule, he decided that "if the railway does not choose to meet the competition, the Board's whole right to interfere with the rate is confined to a case where the rate as charged is unreasonable for the service rendered." ${ }^{2}$ Hence, in the case of towns, as of districts as a whole, the discretion of the railway official appears to be vice for nothing for a similar or considerable distance, the Board could order that Nanaimo should get the benefit of this 69 mile haul for nothing, on the ground of discrimination." VI J.O.R.R. 9.

1 VI J.O.R.R. 371.

${ }^{2}$ Ibid., 9. 
fairly complete. The ultimate effect of this is to strengthen the movement toward the concentration of trade and industry in large centers with established advantages. Cautious entrepreneurs will not locate in districts where competitive advantages in the matter of rates may later be withdrawn.

Another problem emerges. This is the problem of the - equitable adjustment of fixed costs upon the different portions of the railways. This becomes of greater importance when it is recalled that the long haul north of Lake Superior, with lack of local traffic, with difficult curves, and severe climatic conditions, means that costs incurred there must be provided for elsewhere. It is also quite clear that if the rate levels of Eastern Canada are determined by the presence of water competition, then the burden of fixed costs to that degree does not fall there. The conclusion develops that it must fall upon Western Canada, where the rate levels are admittedly higher and where water competition does not exist.

It requires to be pointed out, however, that the benefits of low rates in the East in some ways is shared by the West. In so far as the West ships out its surplus commodities to the Eastern Provinces or the seaboard, it enjoys the benefit of water-compelled rates from the head of the lakes. Similarly, in so far as it imports its supplies from the East these benefits accrue. In brief, the vast interregional trade carried on between these two markets is upon an equal basis, with the additional advantage to the West of lowered export rates. Hence the Board, after surveying this situation, declared that there was no undue preference to the East and gave judgment accordingly. The weight of discrimination is reduced by these considerations to the differences in rates between local traffic in the East and local traffic in the West. Or, from another point of view, any advantage the West derives from canal expenditure is to be set over against a greater burden of 
fixed costs exacted through high rates on local traffic. The railways are charging what the traffic will bear, and the only parts of Canada available for this procedure are the Prairie Provinces.

This inequality between local rates in the East and in the West has been reduced slightly by the Eastern Rates decision. The Chief Commissioner, who wrote the judgment said, "I am aware that an absolute parity is impracticable, but as conditions become similar, a reasonable parity ought to be obtained." 1 It will be recalled that the application for an increase in local rates in Eastern Canada followed the granting of a five per cent increase by the Interstate Commerce Commission to the United States railways operating in official classification territory. While an advance in rates on the American lines may warrant certain advances in Eastern Canada rates, the view that conditions in time will become sufficiently similar to bring rates substantially to a parity appears illusive. The great element of dissimilarity, the presence of waterways in the East, is an abiding factor of difference not capable of change. Other counter-balancing factors may bring about an equality of rates, but not similarity of conditions.

A highly probable effect of higher rate schedules in the West is that the development of manufacturing and distributing centers in the Prairie Provinces will be retarded. The Eastern manufacturers have the advantage over Western competitors. While both Eastern and Western manufacturers enjoy the benefits of low interregional rates, to the former alone is there also the benefit of really low tolls in the local constituency. The Western Rates decision buttresses this situational advantage only by recognizing the facts controlling a difficult and intricate rate situation.

There remains to be considered the broader significance

1 VI J.O.R.R. 154. 
of these decisions upon rate regulation and upon the Board of Commissioners. In holding that the higher rate levels in the West as compared with the East is not unjust, the Board has not allayed the original cause of irritation. The grievance is bound to be ventilated again in the future, and since the Board has exhaustively dealt with the problem and given a decision that in the light of all the existing circumstances can scarcely be challenged, it would be a bootless task to approach that body with hope of relief. Recourse can only be had to Parliament with hope of success, for the difficulties are such that they do not arise from a lack of legal authority on the part of the Board, but inhere in the concrete physical situation. Facts, revealing the financial difficulties of the Canadian Northern Railway system and the Grand Trunk Pacific, that have transpired since the decision was announced, clearly show that if the Board at that time had put rates on a parity East and West, it would have hastened the present railway crisis in Canada. It would have accelerated a condition of affairs against which the whole tenor of the Board's opinion has stood in the past. Since the Board has failed to settle the difficulty, the duty will devolve upon Parliament to make the attempt. When this occurs it may check the present trend to increase the powers of the Board that recent years have witnessed. It depends largely upon the method of settlement devised.

It has been argued that relief for the West will be found in the construction of the Georgian Bay Canal, which would provide a short route from the Great Lakes to tidewater. But it is obvious that while this might offer compensating advantages in so far as it would extend the range of water competition, the problem of high local rates in the West would be aggravated. Further, as a matter of fact, if this route meant a large diversion of traffic from the St. Lawrence route, it would in a slightly different shape be reproducing the effects of the Grand Trunk Rail- 
way upon that route. It would mean that expenditure upon the Welland Canal and elsewhere would be lost except in so far as a trifling local traffic was concerned. Again, if the Georgian Bay Canal deflected a great deal of traffic from the three transcontinental lines the effect would be to delay the period when all of these lines would come to financial stability. None of these considerations is in itself a sufficient reason to dismiss lightly the Georgian Bay Canal scheme, nor perhaps are they of great weight when considered together, but they are elements in the situation and must be reckoned upon.

It is conceivable, though as yet problematical, that the Hudson's Bay route, at present ${ }^{1}$ being built by the Dominion Government from a point in northern Manitoba to Port Nelson may provide a solution. The road would introduce a new factor into the competitive situation and might thereby cause the reduction in freight rates in the West to something nearer the Eastern level, even though it would likely be burdened by the necessity of carrying in the costs of operating an expensive and in itself an unprofitable line between Port Nelson and Le Pas. The rates it would most keenly affect would be the export grain rates from Saskatchewan and western Manitoba east to the head of the Great Lakes. The gain would lie probably not so much in the difference of railway tolls to Port Nelson as in the gain in the ocean rate from Port Nelson to Liverpool, compared with the rate from Fort William to Montreal or Quebec, and from either of the latter points to Liverpool. But in that event, if the findings of the Board be correct, that the higher levels of the West are necessary on present volume of traffic to guarantee fair return on capital invested in railways, what will become of them? There can be only one answer. We may predict an era of low earnings or deficits. This position assumes that the Hudson's Bay Route will prove a success. This, however,

1 Canada Year Book (1915), p. 476. 
is not to be assumed. The distance from Liverpool to Port Nelson is 2966 miles as against 2647 to Quebec. The distance from Le Pas, in northern Manitoba, to Port Nelson is 424 miles. The distance from Quebec to Winnipeg is approximately 1350 miles. Hence, other things being ignored, as a matter of mileage the advantage claimed for the Hudson's Bay Route is the advantage of roughly 950 miles less inland carriage against a sea carriage of less than 350 miles additional. This statement, however, ignores the really vital consideration, to wit: the navigability of the Hudson's Bay part of the northern route. There are grave possibilities that the shortness of the season, the dangers of ice, and difficulties of securing steady shipping service will make the route of minor importance. Indeed, there are many elements to be considered and the permanent factors in the physical situation are not sufficiently known to forecast the final adjustments.

Happily it is possible that another way out may appear. Western levels may be able gradually to stand reductions without ill effect through an increasing density of traffic in Western territory, or, in the event of the Government line to Hudson's Bay compelling reductions, the power of the other railways to stand the same in the West may have been underestimated by the Board. It is obvious, however, that just here there are chapters yet to be written in Canadian railway history.

Several minor principles grow out of the Board's attitude toward water competition. Water competition to be recognized must be efficient. In Plain \& Company vs. The Canadian Pacific Railway, ${ }^{1}$ where discrimination was alleged as between two points on the line, both touching the Rideau Canal, it was held that "where a railway chooses to meet water competition, it is to be presumed, unless the contrary be established, that it does so because there is effective competition in regard to traffic important in $15 / 208$. 
amount." When the Canadian Portland Cement Company applied for a reduced rate on coal from Black Rock to Marlbank, comparisons with the rate to Kingston and Belleville were offered, but it was shown that while coal might move by water to Marlbank, yet it was not moving in sufficiently large quantities to meet the needs of the business. As coal moved freely to other points the comparison failed. ${ }^{2}$ The doctrine of the limited efficiency of competition is a variant, another phase of this point of view that goes a little farther. The Dominion Sugar Company located in western Ontario complained that the rate on sugar to Toronto was unjust in comparison with the rate given to competitors whose establishments were located at Montreal. The rate from Montreal was defended by the railways on the ground that it was compelled by water competition. The Dominion Sugar Company showed that shipments were also possible and actually did take place by means of water carriage. In point of fact it developed that the traffic went chiefly by rail. The Board refused to disturb the rates, holding that

carriers may in their discretion meet effective water competition from one point to another point by reducing their tolls, and it is not unjust discrimination for them to charge higher tolls from another point having a limited efficiency in such competition to these points. ${ }^{2}$ With varying intensity of water competition the railway may meet it in a varying degree. ${ }^{3}$

More important is the recognition that the intermittent character of waterway competition must be recognized. The enunciation of this principle grew out of a rehearing of the Sugar Case, just discussed. ${ }^{4}$ On this occasion the applicants showed that during the winter season of the year there really was no effective water competition between Montreal and Toronto. On that basis they alleged unjust discrimination during that portion of the year. The Board accepted this pleading, declaring that "to some extent the

1 5/232. 217 C.R.C. 231. ${ }^{3}$ VI J.O.R.R. 370. ' 17 C.R.C. 240. , 
water-compelled rate should fluctuate with its controlling rate." In other words, a carrier by rail may be justified in reducing tolls from one place to another to meet effective water competition between those points, notwithstanding that the lowered toll appears discriminatory as against a third point which is not affected by such competition and which is therefore subject to higher tolls, but, a continuance of the competitive toll, after the water competition ceases or is suspended (e.g., in winter), constitutes unjust discrimination against such a third point. Logically the holding would mean a vast readjustment of tolls every spring and fall in Eastern Canada; the railways, however, prefer to give an averaged lower rate on traffic for the year than to follow the other procedure.

The suspension of active water competition may arise from causes other than the recurrence of winter. Following a breakdown of active water competition via the Panama Canal the Canadian railroads in February, 1917, filed a tariff with various increases on the movement to the Pacific Coast of Canada. The tariff in question affected a large list of commodities. It was shown that previously, in December, 1915, the Canadian roads had reduced rates to the coast to meet this water competition. In both the reduction and the proposed advance the Canadian lines followed the lead of the American railroads, both the reduction and the advance having been sustained by the Interstate Commerce Commission. ${ }^{1}$ The Canadian Board summarily dismissed the complaints of shippers against the proposed advance by holding that a prima facie case for suspension of the tariff had not been made out. "The situation turns," it said, "on the question of water competition, which the Canadian railways met in a measure when the competition was more effective and which they now meet in a less degree when the same competition is less effective. This is not contrary to the Railway Act." 2

132 I.C.C. $611 ; 40$ I.C.C. 35.

? VI J.O.R.R. 501. 
On the other hand, while water competition must be efficient to be effective, as an element in a rate situation it need not be actually in existence. Potential competition by water will justify a rate which would otherwise be adjudged discriminative. The position of Winchester ${ }^{1}$ on the Canadian Pacific Railway, seventeen or eighteen miles inland from the Grand Trunk Railway at Cornwall on the St. Lawrence, may be cited. Winchester was taken as an illustration by the Board and the conclusion arrived at was: -

Business could not very well be worked up along the line of the Canadian Pacific should a higher rate be charged by that company than that forced on the Grand Trunk by water competition at Cornwall, where water competition either real or potential, certainly exists.

The railways, the Board said, would be justified in adopting rates to Winchester and similar points which would "permit traffic to move and enable the railway to earn something over and above operating costs." However, "in order to be entertained as a justification of a lower rate basis the effect of water competition must be discernible." ${ }_{2}$

In the British Columbia Interior Rates Case, where the Pacific Coast jobbers appealed against low rates on Eastern traffic to interior points, it was held that these were justified: -

The railway company is allowed to meet competition at coast points, and I think that it should be equally allowed to meet the effect of that competition upon interior points to a reasonable extent. ${ }^{3}$

Naturally it follows that, where water competition has declined in importance, rates may be advanced without incurring the presumption of unreasonableness. This position is clearly developed in the holding in the case of the Dominion Millers' complaint against an increase of
1 File 18755, Judgment, pp. 18-19.
2 VI J.O.R.R. 491.
3 $3 / 136$. 
rates on flour to the Maritime Provinces. It was shown that competitive rates had been in force, based upon the New York rate to Boston plus the vessel rate, port charges, and marine insurance, but that competition by this route was declining. The Board said: -

If competition forces the rate of a railway below its normal basis, it follows that when the competition is less effective the railway may bring its rates up more closely to its normal basis. ${ }^{1}$

The trend of these decisions is in sympathy with the Board's main position upon water-compelled rates, and their presentation completes the review of the Board's attitude to this factor in the determination of cases of unjust discrimination.

$\S 3$. It is easy in focusing attention upon the main elements of a situation to lose sight of those of lesser importance. In the matter of geographical location, while the presence of water competition is easily the most striking advantage and tends to overshadow other elements, the competition of carriers must be recognized, for it has produced important modifications in the general rate structure of Canada. This is particularly true with respect to the Lake Erie frontier, where the Michigan Central and Wabash lines come into contact with the Canadian carriers. The attitude of the Board to problems arising out of the competition of carriers is in accord with the position assumed to water competition. The competition of a rival carrier at a given point has been held sufficient cause for a discrimination in rates. A couple of statements may be quoted in addition to those already given in the case of water competition as typical of the Board's attitude. In the Pressed Brick Case, ${ }^{2}$ the rate from Bradford, Pennsylvania, to Detroit was alleged to be discriminatory as compared with the rate to Windsor just across the river on the Canadian side. But the Board refused relief : -

$$
17 / 194 \text {. } 8 / 49 \text {. }
$$


The rate from the Ohio fields fixes the maximum which brick from the Pennsylvania fields can pay. It holds down the Pennsylvania-Detroit rate below the point which it might fairly be expected to pay on mileage. The $\$ 1.60$ rate being concerned with the condition of market competition at Detroit, which does not exist at Windsor, therefore does not afford a measure of the Windsor rate. ${ }^{1}$

Similarly in connection with the complaint of the Fredericton Board of Trade, claiming discrimination in favor of St. John, the Board remarked that "the existence of competition is one factor creating dissimilar circumstances and conditions." 2 At first glance it is difficult to reconcile these holdings with that in The Aylmer Condensed Milk Company vs. The American Express Company with respect to tolls on cream from Springfield to Toronto. The facts are stated in the judgment:-

The situation is that the American Express Company gives the reduced rate of 20 cents for furtherance from Brownsville. Brownsville is $5 \frac{1}{2}$ miles east of Springfield. Brownsville is an exclusive office of the American Express Company. Apparently the rate from Brownsville for furtherance has been put in by the American Express Company in competition with the onecompany rate of the Canadian Express for contiguous stations on the Grand Trunk. While such treatment is given at Brownsville it is not extended to Springfield. The granting of the 20 cent rate for furtherance to Brownsville is an outcome of market competition. While the American Express Company may reduce rates on this account it must at the same time meet any allegation of discrimination as to traffic received under substantially similar circumstances. It has not been established that the traffic received at Springfield $5 \frac{1}{2}$ miles distant is received under substantially dissimilar circumstances. ${ }^{3}$

It would appear that the Board's holding here rests on the basis that competition was as much a factor at Brownsville as at Springfield, and that, therefore, the American

${ }^{1}$ Cp. Wylie Milling Co. vs. C.P.R., 7/252; Guest Fish Co. re Express rates on fish, 10/198.
$210 / 261$.
17 C.R.C. 100. 
Express Company, choosing to meet competition at Brownsville, must choose also to meet it at Springfield. This is implied in the statement that the traffic received at the latter point is not received under "substantially dissimilar circumstances." The case comes very close to the complaint from the merchants at Medway, of discrimination as compared with Liverpool, though in that instance it was stated that the Liverpool Station was favorably situated in the business section of Liverpool and was "therefore in a better position to meet competition." 1 On the other hand, we have the statement here that Brownsville is "an exclusive office of the American Express Company," and it might be presumed that this would similarly put it "in a better position to meet competition." In the matter of charging lower storage tolls at Fort William for goods to be forwarded than for local goods, the Board granted the contention of the railways that tolls which otherwise of a necessity might be charged on a parity might differ one from another as a result of competitive conditions. ${ }^{2}$ Here the railways pleaded that the lower forwarding storage rate was due to the competition of the railways at American ports.

The recognition by the Board of the influence of competition either by water or by rail indirectly settles most of the problems of competing distributive centers. As, however, in certain instances the effect of the Board's policy in this direction has been modified by considerations arising out of the problem of the long and short haul, the whole question. may be conveniently treated when that topic is dealt with.

$\S 4$. Cases have come before the Board where the charge of discrimination has been supported on the blunt plea that the Board should equalize rates to certain markets served by competing producers. To this form of attack upon the reasonableness of a rate the Board has given 
scant respect. Probably the baldest form in which it has been placed before it refers to the rate on sugar from Vancouver to Manitoba cities. By an order of the Board in June, 1908, the rate on sugar between Montreal and Winnipeg was fixed at 71 cents, Portage La Prairie 75 cents, and Brandon 82 cents per hundred pounds. Wallaceburg, in western Ontario, via the Canadian roads, had the same rate. In 1910 the Père Marquette Railway issued a tariff quoting a rate of 60 cents to Winnipeg, 68 cents to Portage La Prairie, and 71 cents to Brandon. Thereupon the British Columbia Sugar Refining Company complained of the reduction and appealed for relief. The first application was couched in the following terms: "In order to meet this competition of alien railroad, we ask for a 60cent rate from Vancouver to Winnipeg and proportionately reduced rates to Portage La Prairie and Brandon." To this the Board replied: -

In the peculiar form of competition here presented, which may be called either market or trade competition, we find the products of refineries located in different portions of Canada in competition. Here again it is in the discretion of the railway whether it shall so adjust its rates as to equalize the effects of such competition. This is not simply a question of analogy from what has been decided in regard to other forms of competition; it is a question of authority as well. ${ }^{1}$

The Imperial Rice Milling Company, of Vancouver, applied for a reduction in the rates on rice to Winnipeg in order to put it on an even basis with the Montreal rice millers. ${ }^{2}$ In its pleading it alleged that the rice brought into Montreal from Rangoon was a lower-priced article than the Japanese product, and it was therefore at a disadvantage in the point of trade competition. The Board declined to interfere, ruling that it was not its function to equalize costs of production. Similarly, the application of the Continental Oil Company, Limited, and other oil

$15 / 279$.

$28 / 270$. 
companies of Winnipeg, ${ }^{1}$ drawing their supplies from independent plants in Kansas and elsewhere, for a reduction in the rates on oil and oil products from Duluth, St. Paul, and Minneapolis, to Winnipeg, was essentially an effort to equalize conditions with reference to the oil shippers in western Ontario. This was denied, though the case was disposed of on a minor point.

In The Canadian China Clay Company vs. The Canadian Northern Railway, et al., the clay company sought relief in lower rates to mitigate the severity of the competition of the English companies. The Board said: -

It has been held time and again that rate regulating commissions have no right whatever to attempt to equalize geographic, $X$ climatic or economic conditions. ${ }^{2}$

Similarly, in refusing a request for a lower rate from Clover Bar to Edmonton on sand, in order that the applicant company might compete with sand being shipped in from Fort Saskatchewan, the Board remarked: -

It may be that no business can move under this rate and that the railway company is guilty of an error of judgment in not putting in a lower rate owing to the special competitive features at Edmonton. This, however, has been repeatedly held to be a $\times$ question for the railway company itself to decide. ${ }^{3}$

Quite properly the Board will not permit shippers to secure in a roundabout way what it refuses to grant to them in a direct way. The complaint of Hay \& Company, Limited, Woodstock, and the J. H. Still Manufacturing Company, Limited, St. Thomas, may be cited in illustration. These firms were manufacturers of veneering and handles. They purchased their logs in small lots from farmers. The complaint they made was that they were unable to load a 36-foot flat car with logs to a minimum of 50,000 pounds and they applied for a reduction to 35,000 or at least 40 ,$\mathbf{0 0 0}$ pounds. It was claimed by Mr. Hay that it was not
$17 / 218$.
317 C.R.C. 95.
2 10/327. Cp. VI J.O.R.R. 267; VI J.O.R.R. 286. 
practicable, when shipping logs from western Ontario points, to use a steam log-loader as the quantities were not large enough. It was pointed out that where logs aro shipped from the timber limits in large quantities it is cus. tomary to utilize steam log-loaders or cranes and thus load much more heavily. After a careful survey of decisions of the Interstate Commerce Commission the Board ruled that it would not be justified in directing a reduction of the minimum weight in general because in a particular instance it was slightly in excess of the average loading capacity. "The handicap complained of," it said, "is part of the cost of production ... the railway cannot with propriety be asked to equalize this handicap." 1

There are no data to determine clearly whether the Board would carry its attitude in this respect to the point of completely shutting out possibly effective competition. A case in which this question has been squarely raised has not come before it. What evidence there is points in that direction. Certainly the result of the decisions affecting the carriage of oil is to leave the Imperial Oil Company at Sarnia, the Standard Oil Company's Canadian branch, in the strongest shipping position. This in itself is not an evidence of design on the part of the Board, it need scarcely be said, but appears to be the natural result of the acumen of that company in selecting its location, combined with the natural working-out of the principles upon which the Board has based its decisions. To disentangle the general fact from this particular instance, a logical application of the principles of the Board results in certain points having as it were a monopoly position in so far as transportation is concerned. The Board will not deprive them of this monopoly element even though the advantages that accrue to location there are so great that they might easily be the factor that would place a firm in the dominant position in respect to certain markets.

1 VI J.O.R.R. $474 \mathrm{ff}$. 
Moreover, a railroad may not arbitrarily advance rates to protect a market from competitors who may be more favorably located. This may be illustrated by the Gas House Coke Case. ${ }^{1}$ Gas house coke is manufactured from bituminous coal, upon which there is a duty of fifty-three cents per ton while gas house coke itself enters free. The rate on coal from Suspension Bridge to Toronto is sixty cents per ton. Hence the Consumers' Gas Company asked the railways to give it a lower rate out of Toronto to overcome this disadvantage. Instead of complying with this request the railway increased the Buffalo-Hamilton rate on gas house coke by thirty cents per ton, and the case came before the Board on the complaint of a Hamilton dealer. After hearing the Board held that there was nothing to justify the increase and that the advance must be canceled.

The same position is taken in The Canadian Oil Companies, Limited, vs. The Grand Trunk Company, et al., where the rate on petroleum from Ohio and Pennsylvania points was in dispute. The Board in this case said that if the railroads were trying to protect the Canadian refiners against the importation of crude oil from the United States the object was entirely illegal: -

Railway companies are entitled to enjoy fair and remunerative rates, but they have no right to attempt any rate adjustment out of line with reasonable tolls, with the view of protecting or assisting any one industry, or one section of the public. ${ }^{2}$

A later application of the Consumers' Gas Company shows the application of this principle in the opposite direction. ${ }^{3}$ When the advance in rates from Buffalo was disallowed it filed a complaint alleging discrimination. It was then shown that, over and above any advantage arising through the tariff, the Buffalo Gas Company were getting lower rates for their coke out of Buffalo than the Toronto company out of that city. The Board ordered the
${ }^{1} 6 / 367$.
2 7/199.
$38 / 265$. 
reduction of the latter rates to the same level on the basis of mileage.

The net result of these cases is to show that if a railway voluntarily establishes a low rate from one point and discrimination is shown, it will only be permitted to remove that discrimination by a similar reduction for the point discriminated against. Even if there is a contractual basis to a rate the Board is not precluded from seeing to the maintenance of a reasonable rate. ${ }^{1}$ "Adequacy of consideration is not such a justification for the continuance of a given rate basis as to oust the propriety of that rate basis being made reasonable no matter by whom such application is made." ${ }^{2}$ There is no obligation, however, on the railways to make developmental rates however advantageous they might be on the grounds of public policy.

$\S 5$. It is difficult to show consistency between the views just dealt with and some of the Board's remarks on export rates. This may be due to the fact that the conditions under which the bulk of the export trade is carried on have not led to any considerable amount of rate litigation, and therefore the Board's position has not been fully developed and received definitive form. The great bulk of Canada's exports finds its way to the world's markets via Montreal and the St. Lawrence route. Instead of several actively competing routes there is practically only one by which traffic moves. As a result the Board has been largely relieved of passing upon cases involving export rates. The issue was raised, however, in the Elder, Dempster \& Company's Case, when export rates were refused to commodities moving to Vancouver via the Isthmus of Panama. The discrimination in rates in this instance was defended on the exigencies of competition. The Board declared:-

The products of Canada that move under the export rates come into competition in British and foreign markets with those

$$
1 \text { 4/252. } 2 \text { VI J.O.R.R. } 394 .
$$


of many other countries, and to meet such competition and permit reaching these markets, the railway companies make these reductions in rates to the seaboard. 1

Other phases of this case are not of interest here. The point to be observed is that in the above statement export rates are given justification on the ground that they enable Canadian products to reach certain markets. This is hardly consistent with the view that a railway may not attempt rate adjustments of an exceptional character with a view to protecting or assisting an industry. From the point of view of economics there is little difference between international trade and interregional trade. If there is justification in quoting a low rate in one instance to enable goods to reach a certain market it should be equally valid in the other case. No fault is being found with the end aimed at in this decision, nor with the general proposition that a lower rate may reasonably be granted on export goods, but exception is taken to the justification here employed in view of other utterances of the Board. In the China Clay Case there is a hint of firmer ground in the statement that "if the Board were to adopt the principle that the import rail rate, practically a proportion of the through rate, could never be lower than the local rate, a serious dislocation of business would result." 2 There can be no doubt, in defending lower rates for this class of traffic, that the suggestion that import rates, or for that matter export rates, are to be viewed as proportions of a through rate, is a more solid position to occupy.

It is to be remarked, however, that in cases where the issue of entrance to markets has arisen, the applications have been to obtain admission to a market by a reduced rate rather than cases where such a reduced rate has been under attack as discriminative. The Board has taken the position that it has no authority to order such a reduced rate and has applied this ruling to export rates. The appli-

$$
15 / 281 . \quad 210 / 327 .
$$


cation of the Graham Company, Limited, of Belleville, for a change in classification of desiccated vegetables from fourth class to fifth class was denied because "no obligation is imposed by the Railway Act to give an export rate basis to a port which is lower than the domestic rate basis to the same port." 1 The general attitude of the Board to rates on industry will be discussed more fully in a later chapter.

§6. Certain differences in the nature of the traffic have been held to justify different rates. With a few exceptions these differences have been presumed to mean a difference in the cost of handling the traffic, so that cases considered under this section illustrate chiefly the use of the cost-ofservice principle by the Board in cases where discrimination has been charged. As pointed out, however, in connection with rates held reasonable in themselves, the cost of service which is the basis of the claim is not actually proved, but presumed or inferred by comparison with rates where the particular feature upon which the case turns is present or absent. The more important of these cost factors that come into play here relate to the conditions under which branch-line traffic, joint traffic, and traffic involving a long or short haul are carried on.

The principle that branch-line freight rates might be levied on a higher basis than main-line freight rates was enunciated in one of the earliest cases to come before the Board. In 1904 the Almonte Knitting Company complained of the rate on coal from the western Ontario gateways to Almonte. ${ }^{2}$ The rate to Ottawa and Carleton Junction from the Niagara frontier was $\$ 2$ a ton. The rate to Almonte via a lateral line out of Carleton Junction was $\$ 2.40$ a ton. Ottawa is twenty-eight miles from the Junction and Almonte is seven miles. The Board held that because Almonte was on a branch line that fact warranted a higher rate, but not disproportionately or unreasonably
1 VI J.O.R.R. 265.
$21 / 71$. 
higher. As the arbitrary rate on tenth-class traffic, to which class coal belongs, was only twenty cents per ton above the rate to the Junction, this was taken as the measure of reasonableness and the coal rate to Almonte was reduced from $\$ 2.40$ to $\$ 2.20$ per ton.

In the Tan Bark Case ${ }^{1}$ this principle was confirmed and elaborated. In this instance the rate on tan bark from Sprucedale to Berlin, Ontario, was ten cents per hundred pounds, from Sundridge eight cents per hundred. Sprucedale is on a line eleven miles west of Scotia Junction and is two hundred and two miles distant from Berlin. Sundridge is two hundred and twelve miles from Berlin, twenty-one miles north of Scotia Junction. The Board took the position that the location of Sprucedale on what had formerly been an independent line with light traffic justified a higher toll than that paid on the other line, a branch running from Toronto north to North Bay. More important than the decision for our purpose is the reasoning by which it was justified:-

While not holding that the entire cost of the upkeep of a particular branch line, division or other portion of a railway must in every case come from the receipts of such portion, it must at the same time be recognized that each ton or passenger moving over such portion, must, if the traffic is light, contribute a proportionately higher amount per unit to such upkeep than in the case of a portion of line where the traffic density is greater. ${ }^{2}$

The relationship of branch-line to main-line traffic is a problem of admitted intricacy, and in this instance was the occasion of a notable dissenting opinion. Agreeing with the recommendation of the Chief Traffic Officer, who reported that he was unable to see any exceptional conditions to justify a higher rate from Sprucedale, Mr. Com-

$14 / 268$.

2 Cp. "Amherstburg has a branch line movement from Essex; and might, if any difference were justified, be expected to be on a higher basis." VI J.O.R.R. 419. 
missioner Mills challenged the presumption that branch lines do not make a reasonable return to the company:-

Is it not a fact that the capital invested in branch lines is generally much less per mile than that invested in the main line - less expensive bridges, comparatively inferior roadbeds with sharper curves made to save expense, lighter rails, less expensive stations, lighter engines, and less valuable passenger cars? Is it not also a fact that the service on branch lines is nearly always less frequent, less regular and worth less than that on the main line; and without such feeders the profits on main lines would be greatly reduced? 1

The issue of fact which the dissenting opinion raised has never been satisfactorily investigated by the Board, nor has it defined in any clear way what constitutes a main line as distinguished from a branch line. In the case just considered Sundridge lies on a line familiarly known as the North Bay branch of the Grand Trunk and runs north and south, while Sprucedale is on a line connecting Georgian Bay grain ports with Montreal. On the map the east and west line might reasonably be considered a main line. The logic of the case seems to be that volume of traffic determines whether a line is to be deemed "main" or "branch." In the absence of careful investigation on the part of the Board it must be confessed that its position opens the door to a possibility of tolls grossly discriminative in fact if not in law. In this instance a haul of about eleven miles on the "branch" line was not only held not equivalent to a haul of twenty-one miles on the "main" line, but was held to justify a ton-mile rate approximately thirty-one per cent greater for the whole haul of over two hundred miles.

The decision, however, is in keeping with what has been the general attitude of the Board to geographical advantage. From this viewpoint it differs only from the Board's holdings in respect to water and rail competition in that 
the decision rests upon a putative higher cost of service rather than upon commercial considerations. The general effect is the same - to centralize traffic along the main arteries and retard industrial enterprise elsewhere.

Recent decisions, however, narrow the application of the principle considerably if, indeed, they do not traverse it to some extent. While in the Tan Bark Case, as we have seen, the Board expressed the opinion that if traffic were light the rate might be higher than where the traffic density was greater, in The Two Creek Grain Growers' Association vs. The Canadian Pacific Railway this plea was not allowed. This association complained that while Elkhorn on the main line of the Canadian Pacific was one hundred and ninety-eight miles from Winnipeg the rate was only fiftyfour cents, whereas from Two Creeks, one hundred and ninety-four miles distant, in the same mileage group, the rate was fifty-seven cents. The railway contended that the density of traffic was much greater from Elkhorn, on the main line; in fact that the tonnage out of Two Creeks was insignificant. Two Creeks was on a branch 13.4 miles off the main line, the remainder of the distance being common to both points. The Board replied that the pertinency of this contention (i.e., density of traffic) was not apparent when it was considered that what was involved was a general mileage scale. On this basis it ruled: -

Difference in density of traffic as between main and branch lines does not affect the application of a standard tariff, therefore, all points whether on main or branch line, within the same mileage group should be given the same toll, and it is unjust discrimination to make a different toll against one point in the group. ${ }^{1}$

It is true that in this case the Board compared the rate to other points which revealed the fact that Miniota, also on a branch line, and 196.8 miles distant from Winnipeg, paid the fifty-four cent rate. The language of the de- 
cision, therefore, takes more sweeping ground than would seem necessary under the circumstances. The fact that a standard tariff is affected really does not make much difference. It is at least debatable that if higher rates are justified on the branch line on account of the lightness of traffic, that should consistently find expression in the standard mileage scale. Though it cannot be said on the facts of the case that the Board has departed from its original holding, the language of the opinion would give a colorable suggestion that it has drawn back, certainly to some degree, from its earlier position. The principle, however, is becoming gradually limited and defined. In March, 1915, anent the application of the Edmonton, Dunvegan \& British Columbia Railway to apply the mountain scale of rates to its line, the Board said, "It is, of course, a fact that the Board has recognized that in certain instances a higher rate on branch lines may be charged than on main lines." ${ }^{1}$ In July the decision in the Two Creeks Case set forth that a difference in density of traffic as between main and branch lines does not affect the application of a standard-freight mileage tariff. In November, dealing with the complaint of Herbert Oyler on the rate charged on apples from a point on the North Mountain branch of the Dominion Atlantic Railway Company to Halifax, the Board said, "In general, standard mileage rates are charged to the junction point where the special mileage rates become effective.". ${ }^{2}$ A comparison with this position and the ground taken in the Tan Bark Case reveals the advance that the Board has made in dealing with cases involving branch-line traffic, and sets some measure upon the degree of discrimination against branch-line points after which it will be deemed "unjust discrimination."

Passing from the problem of branch-line traffic we may turn to the question of costs when traffic moves over two or more lines of railroad. Certain items of expense are 
naturally increased. Bookkeeping expenses are higher, cars have to be sorted out at terminal points, and other special costs are incurred. The Board has recognized that this constitutes a proper reason for discrimination in rates where the toll is higher in comparison with that paid on a route of the same length and of the same general nature except that it is under the control of a single company. In reply to a complaint of the Sudbury Board of Trade that the joint rate on coal from the Niagara frontier was higher to Sudbury than to North Bay, distance considered, it admitted that the ton-mile rate to North Bay was lower, but pointed out that it was a single-line shipment while the Black-Rock-Sudbury movement was a threeline movement. ${ }^{1}$ The principle was not given much weight in this decision, although a factor, but received confirmation in an express-rate decision where it was made the controlling element. When the Canadian Northern Railway acquired control of the Central Ontario Railway, the Dominion and Canadian Express companies withdrew in favor of the Canadian Northern Express Company. The latter has few offices in Eastern Canada and an advance in through rates to points in the territory served only by the other companies occurred. The Board upheld the advance on the ground that "traffic handled by two or more companies could well bear a heavier toll than when handled by one only, there being extra expense in transferring, waybilling, and the like." 2

In the Moosejaw Board of Trade's complaint with regard to coal rates it was shown that the rate from the Drumheller mines to Moosejaw, 464 miles, was $\$ 3$ a ton, while the rate from the same point to Regina, 31 miles of a longer haul, was $\$ 2.90$ a ton. Drumheller coal moved to Regina along the rails of the Canadian Northern entirely, but in the case of the movement to Moosejaw the haul was a two-line movement. The Board said: -

$$
15 / 277 . \quad 28 / 278 .
$$


It is a well known principle that a joint service covering as it has to the transfer services from one railway to another, and duplicate accounting, is more expensive than service on a single line. ${ }^{1}$

Similarly, in the China Clay Case, the Board declared that it was elemental that for a given distance, where two lines had to be employed as against the one, the rate would be greater. ${ }^{2}$ Thus, standing squarely on the cost-of-service principle, the Board has recognized the validity of the contention that a difference in rates due to two or more lines participating in the traffic is not unjust discrimination.

The question of costs has been a factor in a number of cases directly raising the long and short haul problem which have come before the Commission. In other instances, while the long and short haul element has entered into the case, other considerations in themselves sufficient to control the decision have been present. The principle, however, has been recognized and accepted as a basic factor in rate-making, though limited in application by the long and short haul clause of the Railway Act. A study of the decisions shows the development of the position, that a long haul may reasonably receive a lower rate than a short haul, the limitations imposed upon the principle by legislative enactment, and the recognition of the Board that under certain circumstances the prohibitions of that clause do not apply.

The general principle of a lower proportionate charge for a longer distance is recognized in both the Sudbury Coal Case and the Express Rates Case already cited. In these cases the Board declared that the only relief it could give was to see that there was a reasonable reduction on the through rates below the sum of the locals. In cases of telegraph tolls provision was made, in cases where there was a movement over two or more lines, for "through

1 10/240. 2 10/326. Cp. VI J.O.R.R. 62; VI J.O.R.R. 329. 
rates substantially less than the sum of the locals." 1 The principle is discussed at length in the opinion based on the general express investigation ${ }^{2}$ where the Board deals with express freight traffic. With reference to joint routes the Board said: -

It seems clear that where express companies establish continuous routes they should at the same time agree upon joint rates for their freight traffic, and a division thereof, and we think that these should be less than the sum of the locals.

The Board here ordered that the through rate should be ten per cent less than the lowest combination of local merchandise rates. This general position is in sympathy with the long and short haul because to any given point there will normally be a through rate. This rate will be a lower rate per mile than the sum of the local rates per mile for the same distance. It follows that a division of a through rate is not a measure of what the local rate for the same distance over the same line should necessarily be. ${ }^{3}$

In making this determination the Board admitted that the question of joint through rates had not been discussed with particularity. The Board quoted with approval from Professor McPherson's study of railway rates, where he deals with the long and short haul, ${ }^{4}$ and cited the practice of the Indiana and the Texas State Commissions as to the amount of reduction below the sum of the local rates. The Board has not, however, independently established the principle of the long and short haul, but has relied upon standard economic theory and American precedents and experience. This is rather remarkable, considering the importance of the principle and the position taken by the Board that "the Board must find its criteria of the reasonableness of Canadian rates within Canada." 5

1 VI J.O.R.R. 62. $\quad 2$ 6/271. $\quad{ }^{3}$ VI J.O.R.R. 348.

4 Logan G. McPherson, Railroad Freight Rates in Relation to the Industry and Commerce of the United States, pp. 239-40.

$58 / 16$. 
The position, however, may be considered fairly established, though there are some exceptions. In the case of coal rates from Ogdensburg to Newboro, Ontario, the traffic moved by three agencies, the ferry across the St. Lawrence, the Grand Trunk Railway, and the Canadian Northern. The latter attempted to charge the local rate for its share in the haul. No joint rate for the traffic had been filed with the Board. In view of the through movement the Board ordered a joint tariff to be filed with suitable reduction below the local rate by the Canadian Northern. ${ }^{1}$ In The Oliver Serim Lumber Company $v$. The Canadian Pacific and Esquimalt \& Nanaimo Railways, where the delivery of ties by the carload was to take place on the Canadian Pacific track at Vancouver, billed to an inland point, the Board held that the lumber company was entitled on a through bill of lading to the benefit of the through toll to the point of delivery. This involved a reduction below the sum of the local rates between the same points. ${ }^{2}$

With regard to exceptions the force of these holdings is perhaps weakened by the Board's statement in The Canadian Oil Company, Limited, vs. The Grand Trunk and Canadian Pacific Railways, ${ }^{3}$ that "the through rate may be the sum of several locals," though the particular problem under discussion at the time was the method of forming the rate rather than the amount.

In the Stoy Case, which went to the Supreme Court, where the question of the Board's jurisdiction to sanction a through rate from American points was confirmed, the Board said:-

Oil could move from Windsor or Sarnia over the Grand Trunk Railway to Buffalo at the rate covered by the tariff and under the classification in question; but to intermediate points in Canada, over the same route, higher rates are being attempted to be en- 
forced, thereby discriminating against the Canadian consignee. Such results should not be permitted unless the respondents are entirely within the provisions of Canadian law. ${ }^{1}$

This indicates the attitude of the Board as to the extent to which the principle should be granted recognition. It is in accord with the inhibitions of the long and short haul clause, for while the statute recognizes that tolls may be proportionately less for a longer distance, where a through rate exists the law is that it shall not be greater to an intermediate point over the same line. This was the burden of the International Rates Case, ${ }^{2}$ where the Canadian cities of western Ontario complained that the rates from Detroit and Buffalo to Montreal were lower than from Windsor and other intermediate points on the same line. The Board ordered that the rates from Detroit to Montreal and Toronto should be the maxima easterly and that the other points should be proportionately scaled to them. In this instance the Board really validated a compromise arranged by its chief traffic officer and the interests affected. It is necessary to bear this in mind, otherwise the holdingdown of rates to the Detroit level might appear repugnant to the principle that competing points are without the operation of the long and short haul clause. ${ }^{3}$ When the complaint was entered the Board, in suggesting a conference, in a letter to the chairman of the Advisory Committee of the Canadian Freight Association said: -

The Board recognizes that the conditions of this traffic are affected by the existence of companies in the United States independent of those operating in Canada, and by the operation of the corresponding clause (the long and short haul) in the statute law of the United States . . . and it thinks the Canadian railway companies should be given an opportunity to lay a scheme before the Board, etc.

A clearer-cut illustration of the effect of the long and short haul clause occurs in a group of cases relating to
$5 / 211$.
$23 / 5 \mathrm{ff}$.
${ }^{3} 10 / 198$. 
traffic in prairie territory. The key to these decisions lies in the attempt of the newer towns and cities of the West to deprive Winnipeg of part of the distributing trade and engross it to themselves. Until 1907 the Winnipeg jobbers had reshipped their goods out on the balance of a special through rate which gave them a secure hold on the market to the detriment of firms located in cities farther west. As a result rates from Portage la Prairie to points farther west were actually higher than rates to those points from Winnipeg. Portage is on the main line fifty-five miles west of Winnipeg, so that the case was a clear instance of discrimination in favor of the larger center. The Board promptly disallowed the tariffs, as against the statute. In this decision the question was fairly met and it illustrates the central position of the Board. ${ }^{1}$ The Board said that the tariffs had no real argument in their favor and specifically referred to the fact that it was a case of the railways trying to maintain a higher rate for a shorter distance than for a longer when the shorter distance was included in the longer, and therefore illegal. This applies also to through lake-and-rail rates where such arrangements exist. ${ }^{2}$

The converse problem has arisen where the complaint has been that the sum of the locals was less than the through rate. While it did not consider it necessary to issue a general order the Board has declared ${ }^{3}$ that it considers it a fundamental principle that there can be only a single legal rate between two points and that a joint or through rate in excess of the sum of the locals is prima facie unreasonable and discriminatory. An attempt was made to have admitted the principle of holding that any combination that could be figured out lower than the published through rate might replace the through rate for that route. The Board refused to sanction it. It cited the unsatisfactory nature of this procedure as witnessed by the experience of the Interstate Commerce Commission and the cer-
$14 / 265$.
2 VI J.O.R.R. 505.
${ }^{3} 5 / 216 \mathrm{ff}$. 
tainty of confusion that its use would cause. ${ }^{1}$ In an early case, The Canadian Canners, Limited, vs. The Canadian Pacific Railway, ${ }^{2}$ the Board really accepted this position inferentially, for it held that a combination rate composed of a commodity rate and a local rate, which was lower than the through rate, was the proper one between the two points: -

It may happen that ignorant shippers will not be given this privilege, while those better informed will obtain it; but the informed shipper should not on that ground be refused the lower rate.

The Board, however, has drawn back from this position. Referring to this case it said: -

It is apparent that this was a decision after investigation on particular facts and regarding a particular case. ${ }^{3}$

Moreover, while the rate higher than the sum of the locals may be prima facie unreasonable, it does not follow that it is thereby illegal or unreasonable in a given case. In an application to direct that a joint toll from Russell to Point Levis via the Ottawa \& New York, Canadian Pacific, and the Intercolonial Railways should be reduced to the sum of the locals charged between the same points by the Grand Trunk and the Intercolonial Railways, the Board reaffirmed the view that at any one time there is only one legal rate between two points. In this instance the Grand Trunk quoted a rate of thirteen cents on lumber, the sum of two local rates. For some reason thirteen carloads were routed via the other lines, and a case came up on the ground of overcharge, the rate levied being fourteen cents. The Board refused to find that there was an overcharge, and held that fourteen cents was the legal rate for the route over which the traffic had moved. ${ }^{4}$

1 The obligation upon the carrier in the absence of specific instruction to send the goods forward in routing off its own line, upon the lowest rate, is not here in question. 11/129.
$3 / 126$.
${ }^{3} 5 / 218$.
18 C.R.C. 6. 
However, whether this really advanced on the position taken in the general order for joint freight and joint passenger tariffs is doubtful. While the Board ruled that there was no. ground for an overcharge, it did not directly meet the question whether the fourteen-cent rate was unreasonable and left itself free to consider that question should it come up on direct attack. The case does illustrate the reluctance of the Board to establish any canon of reasonableness that would tie its hands and prevent its acting after investigation. It is therefore really in line with its statement in the general order covering joint rates. In the general order the whole problem of the relation of joint tariffs to the sum of the locals is discussed. The draft order submitted to the Board asked it to accept the view that a through rate might be made up by a combination of a commodity rate and a local rate. To this the Board replied:-

A commodity rate is established because of special conditions of volume of traffic, competition, etc. I for one cannot conclude in advance of an investigation that such a commodity rate in respect of traffic moving between two given points is in any sense the measure of the reasonableness of a through rate to a point beyond. ${ }^{1}$

In sympathy with this is the holding that competition creates circumstances that justify the suspension of the operation of the long and short haul clause. The statute contemplates such a position and cases considered under the section dealing with competition illustrate the application of the principle. In the general express investigation finding it is set forth in general terms:-

Competition between carriers by rail, and competition between carriers by water and carriers by rail, create favored locations to and from which tolls are lower and to which the long and short haul clause has no application. ${ }^{2}$ 
This has been extended in interpretation so that in the case of passenger traffic "pervasive" competition is recognized as justifying competitive rates at intermediate points on the main-line movement. ${ }^{1}$ "The potential choice of the prospective passenger spreads the effect of competition over the whole journey." The occasion of this ruling was a complaint by the city of Fredericton that the Canadian Pacific Railway made the Moncton-Montreal rate, a rate made in competition with the Intercolonial Railway, the maxima for St. John and intermediate points between St. John and Moncton. The rate from Fredericton was made by adding to the competitive rate the one-way fare to the junction point. The Board said that competition is one factor creating dissimilar circumstances and conditions, and where found to exist the lower rate may be allowed, a holding that works out the implications of the British Columbia Interior Rates Case.

The general attitude of the Board to this intricate phase of rate adjustment may now be summed up in a few sentences. (1) A lower rate than the sum of the locals should apply to through traffic. (2) Rates to intermediate points should not exceed the through rate or the sum of the locals. (3) Where the through rate is higher than a combination of the locals it is prima facie illegal. (4) The balance of a through rate may not replace a local rate to points beyond. (5) The reasonableness of a rate composed of a combination of a commodity rates and a local rate will be determined in the light of the particular circumstances. (6) There is only one legal rate between two points. Rates compelled by water or rail competition are not subject to the restrictions of the long and short haul clause wherever such competition is effective.

Certain cost considerations, such as distance, density, and similar factors, remain to be considered. We have seen that cases involving branch-line traffic, joint-line traf- 
fic, and the long and short haul exhibit certain elements of cost which justify a difference in rates where the other conditions of carriage are substantially similar. In these cases involving discrimination the rate is not attacked as being in itself unreasonable. Under the category of rates per se unreasonable ${ }^{1}$ it will be remembered that it was shown that while some use was made of distance as a measure of cost of transportation, on the whole it was relegated to a place of inferior importance. More extended use is made of the principle in cases of discrimination, ${ }^{2}$ though the Board has repeatedly declared that it is "idle to compare rates one with another on a strict mileage basis," 3 holding that distance is not a sufficient basis of comparison, but that there should be a similarity if not "identity of conditions." 4 Still the definite nature of the data, where other conditions are substantially similar, makes them peculiarly valuable in cases concerned with discrimination, and they have been used with considerable frequency as a factor in cases of this sort.

In the Regina Rate Case, ${ }^{5}$ part of the struggle of Western cities to secure the same treatment as Winnipeg with regard to the possibilities of distribution, it was complained that special class freight tariffs to Winnipeg discriminated against Regina and other Western cities. It was shown that the rate from Fort William to Winnipeg, 419 miles, on first-class freight was 86 cents per hundred pounds, or at a ton-mile rate of 4.11 cents, while to Regina, 777 miles, it was $\$ 1.76$ per hundred, or at a ton-mile rate of 4.53 cents. Other classes of freight when compared disclosed a similar disparity. The railways defended the discrepancy on the ground that contracts between various railroads and the Province of Manitoba had resulted in lower rates to that Province and that these contracts established a dissimi-

1 Chapter VI.

2 "Distance is an important factor in the measure of discrimination." VI J.O.R.R. 38.
. $10 / 241$.
4 9/274.
$56 / 169$. 
larity of condition that justified the difference in rates. The Board replied that it could not surely have been the intention of Parliament to permit railway companies to create different circumstances and conditions by entering into a contract with some one that would defeat the clause enjoining equality of treatment to shippers:-

The "circumstances and conditions" which, if not substantially similar, may justify different treatment to different points, I think must be traffic circumstances or traffic conditions; not circumstances and conditions which may be artificially created by contract. ${ }^{1}$

As a result of this view a similar reduction was ordered to apply to Regina and Moosejaw. This was later extended to Edmonton. In one aspect the holding of the Board was overturned by the Supreme Court, which said that contracts were circumstances and conditions to be considered. ${ }^{2}$ It did not, however, affect in a practical way the Board's holding, for the latter declared, when the case was reopened, that it had considered them and that the order issued was not inconsistent with the Supreme Court's decision.

Western cities were not put on an exact parity with Winnipeg even by this decision. By the terms of the agreement with the railway companies in Manitoba, the special class rates were those of the 281-290 mile group in Manitoba Standard Tariff, on freight from Fort William to Winnipeg, instead of the actual distance. The Saskatchewan scale of standard rates being higher than the Manitoba scale, the rate for 290 miles in the latter was the same as the rate for $\mathbf{2 5 0}$ miles in the former and the shrinkage was made correspondingly less.

Finally, this difference was also wiped out. In the Western Rates Case this relief was especially asked for by the

$16 / 172 \mathrm{ff}$. 36.

2 This holding is of importance in the telegraph rates case. VI J.O.R.R. 
Provinces of Alberta and Saskatchewan. The railways contended that the justification of the lower rate in Manitoba lay in a great density of tonnage. To this the Board answered that the class of commodities offered for carriage and the climatic and operating conditions of the districts are very largely the same, and that -

to treat the case, therefore, merely on the question of density of tonnage would be simply to use traffic derived in part from Saskatchewan itself as a reason for denying Saskatchewan the removal of a discrimination existing in the territory subject entirely to like operating conditions. ${ }^{1}$

The Board accordingly ordered the extension of the Manitoba Standard Tariff to the whole prairie area and changed its name to the Prairie Standard Tariff. Thus, by a succession of steps Winnipeg and Manitoba have been deprived of the advantages they had obtained, and the whole area between the Great Lakes and the Rockies has been put on the same level in respect to class rates through the medium of a mileage tariff. Distance is the controlling principle. The fact that it is does not mean that it is mechanically employed, but that fundamentally the class rates between any two points are in some measurable relationship to the distance. The lack of consistency of the reasoning here with that employed in the Tan Bark Case with respect to branch-line traffic has been adverted to in the complaint of the Two Creeks Grain Growers' Association, which logically follows in its disposition the Western Rates decision. In connection with the importance of the factor of density in rate-making it will receive further consideration.

These Western cases, involving large areas where freight moves under like conditions, exhibit the most important use of the distance principle by the Board. These decisions may be compared with those of the Board which concern

1 File 18755, Judgment, p. 51. 
grain rates from the Lake ports to interior elevators in Eastern Canada. ${ }^{1}$ Here the Board ordered the railways to equalize rates for equivalent distances. In brief, the general principle may be stated to be that where traffic of the same class moves under substantially similar conditions the traffic will be based on distance with due regard to and subject to the limitations of the principles of the long and short haul. " "If no extraneous disturbing conditions are present," distance "affords on the average a working measure of reasonableness." 3

The principle that density of tonnage may be disregarded when the traffic which accounts for the density originates in adjoining territory where operating conditions are similar, is worthy of some consideration. ${ }^{4}$ Except on the basis that volume of traffic has a negligible effect on lowering cost of moving freight, it is difficult to interpret the holding. Examined narrowly it would seem that it rests either upon a purely legal foundation or upon broad views of public policy. At that, it is to be noted that it certainly is at variance to the reasoning applied in the Tan Bark Case, for, if volume of traffic is negligible as between Provinces, it surely cannot be maintained that where the traffic is light each unit shall bear a larger proportion of the fixed costs, and that is what the Tan Bark Case stands for with respect to branch-line traffic. To some degree this contrary holding marks a recession from the rigid application of the advantages of location principle that the Board has so frequently applied. The Manitoba shipper and consumer is prevented from reaping any advantage out of the fact that tonnage is heavier within that Province on account of its proximity to the Great Lakes. The recency of the decision re Western Rates renders it impossible to determine whether this represents a broaden-

${ }_{1} 6 / 146.4 / 302 . \quad{ }^{2}$ Cp. 8/58 rates on wire; VI J.O.R.R. 287, 490.

8 VI J.O.R.R. 39.

4 Cp. recognition of factor of volume in telegraph tolls. VI J.O.R.R. $55,59,61$. 
ing of the attitude of the Board to problems where questions of public policy are at issue.

It has already been pointed out that the principle of distance in rate-making becomes important only when operating conditions are similar. This may be illustrated more fully by a consideration of The Vancouver Eastbound vs. The Winnipeg Westbound Rates Case. ${ }^{1}$ The complaint preferred was that undue preference was given to traffic from Winnipeg westward as compared with that from the coast cities eastward. The complainants relied mainly on comparison of the respective distances that goods could be carried at a given rate from these two points. ${ }^{2}$ They claimed that the levying of a higher rate for a shorter distance raised a presumption of unjust discrimination. At first blush, it might appear that the foundation of the complaint was that traffic moving in opposite directions on the same portion of the same line was being charged different rates. In reality the case rested on a comparison of traffic charges for distances chiefly on different portions of the same line, though moving in opposite directions. The Board emphasized a dissimilarity in the circumstances under which transportation is conducted out of Vancouver and out of Winnipeg. It said that the evidence had established that the grades were much heavier and the line much more difficult to operate in British Columbia than in the prairie Provinces. As a result the application to equalize these rates at a point farther east was refused.

On the other hand, in certain instances where operating conditions are dissimilar for part of the movement mileage equivalents have been worked out. Thus, in the case of traffic moving from British Columbia into the prairie Provinces, the Board, by the Western Rates judgment, created one mountain scale on the basis of $1 \frac{1}{2}$ for 1 of mountain mileage, and thus greatly simplified the rate structure. On

$14 / 207$.

${ }^{2}$ Cp. 9/285. 
account of an agreement between some of the lumber mills and the Canadian Pacific Railway the former arrangements for lumber were continued. The lumber-rates scale followed no definite scheme, but was worked out on the idea of letting all mills share the business. However, the Mountain Lumber Manufacturers' Association objected that the rates discriminated against Golden on the main line in favor of Fernie on the Crowsnest branch. In the lumber scale mountain mileage, on account of heavier grades on the main line, was reckoned at 2 for 1 for mountain mileage against $1 \frac{1}{2}$ for 1 on the Crowsnest branch. The actual mileage from Golden to Calgary is 171.7, from Fernie to Calgary 215.2. Under the system obtaining this gave a constructive mileage for Golden for 276.3 and for Fernie 233.1. Under the principle applied elsewhere in the Western Rates Case, constructive mileage for Golden would become 224, Fernie mileage remaining at 233.1. This laid the foundation of the complaint. Pointing out that the railways had adjusted tariffs to enable all mills to do business, the Board continued: -

While it is true that a specific commodity rate but rarely bears any relationship to the mileage, one would not expect that situation to apply in dealing with a general article of commerce such as lumber, affecting different sources of supply, selling in a common market... if the applicants desire ... a complete lumber tariff based on distance and bearing a reasonable and consistent percentage relationship to the standard maximum 10th class rates, I think they are entitled to it, and to a direction being made to the railway company to submit a proposition for such a tariff. ${ }^{1}$

In the International Pulpwood Rates Case ${ }^{2}$ one branch of the complaint concerned the rates on the Canadian Pacific MontLaurier branch. In this instance also the Board denied relief, assigning as its reason the heavy character of the Laurentian grades. Thus it is quite obvious that
117 C.R.C. 285. Cp. 9/297.
$28 / 274$. 
while distance comparisons may be relied upon as a measure of reasonableness in cases where discrimination is charged, the conditions under which it becomes controlling are relatively narrow and difficult to establish.

In any instance where the railway companies have grouped rates around a common point there has necessarily been some departure from the principle of distances. A number of complaints has caused the Board to investigate and consider this practice. Group rates have been applied to the carriage of cream to cities and creameries, also to the distribution of coal from mines located within a certain area. The system worked out for the collection of cream is a modified group-rate system. The scale of rates is graduated to twenty-five mile zones, the increase becoming proportionately less as the distance advances. In the East these rates are calculated for a distance of two hundred miles, ${ }^{1}$ in the West to three hundred miles. ${ }^{2}$

In the coal areas in Western Canada the problem is more difficult, as the mines lie for some distance along the railroad. The method devised has been to give the whole area a rating to surrounding territory, but subdividing the area into sub-groups, giving the particular sub-group nearest any point in question the common rate, while the other sub-groups would take the common rate plus an arbitrary. This arrangement was challenged before the Board in the complaint of the Galbraith Coal Company, ${ }^{3}$ which alleged that the effect of the tariff was to unduly increase the difference in rates between Lethbridge and its mines at Lundbreck seventy-four miles west. The railroad defended the system, claiming that a direct mileage scale worked too much discrimination between mines belonging practically to the same group, and the sub-groups enabled mines to be given the same rate where mileage, gradients, and physical difficulties could all be taken into consideration. The Board said that it was evident that
$7 / 268$.
$28 / 16$.
3 6/149. 
the railway had made a careful attempt to take care of the various conditions arising and refused to find discrimination in the system. It ordered merely that the rate should be modified where a "too rigid adherence to mileage" caused the break between groups to become a hardship.

The discretion of the Board to sanction group-rating arrangements is also recognized in The Eureka Coal \& Brick Company vs. The Canadian Pacific Railway, where a grouping arrangement controls the shipments of coal from the mines in the Souris River Valley. ${ }^{1}$

That the justification of group rating in the eyes of the Board appears to be in the fact that where applied it has had to do with industries carried on under common conditions within a well-defined area, ${ }^{2}$ is well shown in the case of The Fullerton Lumber and Shingle Co. vs. The Canadian Pacific Railway. Here the lumber company complained that to some shipping points the through rates were in excess of the sum of the locals. The Board replied that if one looked at the matter from the standpoint of distance, any group arrangement presented anomalies:-

A group-rate arrangement endeavors to average distance and public convenience. If each point of a group is to be singled out for special treatment on a mileage basis, then the group disappears and the points with the shortest mileage get an advantage in marketing. But it has been recognized that in the case of bulky articles of general demand, it is in the public interest to equalize, within reasonable limits, distance so that there may be as large a supply as possible in the consuming market. Grouping in this case is concerned with the handling of lumber from common sources of supply for sale in a widely extended market.... The rate must be looked at from this standpoint not from mere distance. $^{3}$

Similarly, the Board also validated, "as a matter of practical administration," the zone system in connection with telegraph tolls. While doing so it repeated the statement that in any system of zones there were anomalies.
$16 / 328$.
$211 / 154$.
s $9 / 308$. 
These it held would be reduced if the zones approached each other nearly in dimension. In the matter of telegraph message rates zones were reduced to a parity, not only in the initial charge, but also in extra words. ${ }^{1}$

Volume is another element to be considered here, for, although the Board has declared that density of tonnage may be ignored in adjusting general rate levels, it has rather tended to give considerable weight to volume. Thus, in the case of pressed brick moving from Bradford, Pennsylvania, to Windsor, Ontario, where the rates were compared with those levied on coal, the Board said, "it is to be recognized that the volume moving is a factor in the determination of the rate." ${ }^{2}$ The issue is raised directly in the case of the rate on lumber from Tynehead to Cloverdale, British Columbia, when it was shown that the rate from Tynehead to New Westminster was three cents per hundred pounds, while the rate from Tynehead to Cloverdale, a shorter distance over the same line, but in the opposite direction, was six cents. ${ }^{3}$ The answer of the railway company was that the lumber traffic from Tynehead south was very light, while that from the same point north to New Westminster was heavy. Hence the difference in rates. The Board in its opinion said, "if the facts are as stated the answer is a legitimate one." The decision, however, turned on a comparison with the commodity rate of the Canadian Pacific and some reduction was ordered. The comment, notwithstanding, made it appear that the Board was prepared to give rigid effect to the clause which provides that the tolls for larger quantities might be proportionately less when carried under substantially the same conditions. It is unfortunate if this interpretation of the clause was the safest one that could be given. As between carload and less than carload traffic its justice would be obvious, but if applied as between the shipper of a few carloads and many carloads a door would be opened

1 VI J.O.R.R. 66.

2 9/871.

${ }^{3}$ 6/149. 
for the discrimination between the large shipper and his smaller rival. In this case the actual difference in traffic was not shown, so that the Board disposed of the case on other grounds. The Board, however, is bound by the statute, so that if unfair discrimination should creep in at this point the remedy would lie in an amendment to the act. However, a later case inferentially weakens the force of these holdings considerably. In The St. David's Sand Company vs. The Grand Trunk and Michigan Central Railways the Board declared, "while it is justifiable to base differences in toll on quantity as between C.L. and L.C.L. traffic movement, it is not justifiable to make a difference between carload and train load movements." 1 Under the Tan Bark Case and the argument accepted re rates on lumber moving from Tynehead, the small firm on the branch line could be charged higher rates than the large competitor on the main line on two bases. He was located on a branch line; his volume of output relatively was not large. Under the modified holdings with respect to branch-line traffic and volume of shipment his position is considerably improved. The later position of the Board is also more in sympathy with its holdings with respect to applications for rates for car-lot quantities.

Let us consider the Board's holding on carload and less than carload shipments when these have been directly under review. It is generally conceded that when traffic moves in carload quantities the cost of the service is less than when it moves in less than carload quantities. Mr. Commissioner Mills has analyzed the differences in the nature of the traffic which justify this conclusion. He points out that: -

In the case of carload, no freight shed accommodation is required either at the initial point or at destination; the shipper does the loading at his own expense; the railroad company is paid for full capacity car load, whether the car is filled, half-filled 
or third filled; the car is simply hauled from one point to another fixed point, involving little or no outlay in transit similar to the heavy expense incurred by the frequent shunting of the same car and the handling (loading and unloading) of L.C.L. way freight; and the loss to the company from breakage or other damage to goods is comparatively little, because the shipper (a directly interested party) does the arranging, packing and staying of his goods in the car; and the consignee, another directly interested party, generally does the unloading. ${ }^{1}$

These considerations were advanced in reply to the contention of the railway companies that the inclusion of gramophones in the group of musical instruments that take carload ratings would decrease the revenues of the companies. The Commissioner concluded that it did not necessarily follow that a company secures less net revenue from carload than from less than carload shipments of goods, and recommended that carload rating be given to gramophones. In view of the importance with which the Board has endowed cost factors, the natural supposition would be that this disposition of the case would be unanimously accepted. Of the two Commissioners who considered the case each based his conclusion on different factors in the problem. The application to include gramophones among musical instruments which receive a carload rating was ordered actually because a third Commissioner took the view that gramophones were as much musical instruments as music-boxes, to which the railroads had voluntarily given a carload rating.

Mr. Commissioner McLean, one of the original Commissioners, dissented from this conclusion, holding that the ultimate consumer would not benefit by the change in rate. This dissenting opinion is to be coupled with the disposition of an application by H. E. Ledoux for a carload rating on cigars. ${ }^{2}$ In this case the applicant stated that he was prepared to ship between eight and twelve carloads of cigars annually to Winnipeg from Montreal.

$$
18 / 39 \text {. } 27 / 185 \text {. }
$$


The application was rejected. "The Board held that the granting of the request would reduce the revenue of the company, while there was no evidence that any other manufacturer of cigars in the East would ship any number of carloads westwards: -

Other manufacturers of cigars in the East who do not carry on their business in the same way as the applicants and who have no need of carload rating, as they do not and would not ship in car-lot quantities, would be discriminated against by the preference which such a rating would give the applicants.

Somewhat similarly, in the Tower Oiled Clothing Company Case it was stated that, although the discrimination involved in the difference between C.L. and L.C.L. rating had received tacit assent, a shipper had not thereby the right to demand a lower rate, unless possibly he could show that the carload rate demanded would pay reasonably for the service and that a refusal would injure his business. ${ }^{1}$

These decisions indicate that there is considerable diversity of view as to the sanctions that govern the granting of a carload rating, for at least four or five different positions may be deduced from these opinions. The outstanding fact is that the Board has not definitely taken the position that the reduced cost of handling traffic by the carload warrants a carload rating when it offers in that quantity. This is the more remarkable when it is recalled that it has affirmed the principle that volume of traffic is a legitimate defense to the charge of discrimination. Not less surprising is the weight given to the effect of granting carload ratings upon smaller competitors. In the Canadian Oil Companies, Limited, application for low rate on oil to Winnipeg, ${ }^{2}$ the applicant pointed out

1 1/69.

2 7/211. Cp. Application of the Battle Creek Toasted Corn Flake Co. for a C.L. minimum (6/314); also application of Lamontange's Limited (7/187). 
that the Imperial Oil Company could command a lower rate because it was able to ship in tank steamers. To this the Board remarked that this was an incident of largescale production and it would not be reasonable to require the railways to offset this advantage by reductions in rates. Similarly, it has repeatedly held that it is not the function of the Board to equalize costs of production. It is rather difficult to see how the principle has been conserved in these cases involving C.L. ratings. Costs may be equalized upwards or downwards and to refuse a C.L. rating on cigars, which for other reasons might validly be granted, because it would disturb equalized costs of production, savors of inconsistency. This, indeed, the Board appears to have recognized, for in the Ledoux application it remarks: -

At first flush it does not appear reasonable that an application for a car-lot rating should not be granted where it is established that there would be car-lot movements of the commodity in question.

In drawing attention to this inconsistency in holdings, the view taken is not necessarily that reasoned social considerations should not be used as criteria of judgment, but that the Board has deviated in the application of the principles it has itself laid down.

The basis of a special charge, which has been held not to involve undue discrimination, is some special service of which the expense usually may be easily segregated from the main costs of transportation. Naturally, under these circumstances the Board has relied upon cost data in determining a proper charge. At the outset of its activity it laid down an important ruling; namely, that actual cost should determine these charges, and that the railroads should not attempt to make it the basis of a charge for profit. This principle was set forth in disposing of a complaint of the Ontario Fruit Growers' Association that the 
railways were making an excessive charge for icing fruit in transit. ${ }^{1}$ The Board held the system of making fixed charges for icing cars, irrespective of the actual cost of such service, was not based on sound principle, and should be discontinued. In this case the validity of the extra charge was not questioned, the complaint being upon the amount and method of assessment. In accord with this view, when the railway companies desired increased remuneration for refrigerator service in 1916 the Board required them to file particulars of their case. "By this I mean," said the Chief Commissioner, "particulars of the items of cost they rely on as justifying the proposed increased charges." 2

In cases involving interswitching, ${ }^{3}$ where one company is called upon to deliver the cars of another company, the primary issue of an extra charge of any kind was raised. The principles, however, that ultimately were applied to the amount of charge which might be levied, were developed in the London Interswitching Case, ${ }^{4}$ which came before the Board precedent to the Interswitching Rate Case where the wider issues were considered. In the London Case the Grand Trunk, which had been long established at London, possessed extensive terminals, while the Canadian Pacific, whose entry to the city had been more recent, possessed comparatively small facilities. A branch line owned by the Grand Trunk connected the two systems, whereby the Canadian Pacific was given direct ac-

1 1/69. Cp. the application of the Canadian Piano \& Organ Manufacturing Association for a direction to the railway companies to install heaters in box cars in which musical instruments are shipped during the winter months; "unless special remuneration were charged for such a service, I do not think it would be reasonable for the Board to order it." $6 / 318$.

2 VI J.O.R.R. 82. Cp. in the matter of tolls for heated car service: "The justification advanced by the railways for a heated car service charge is one of cost. They ask simply for cost of this service and not for a profit thereon." VI J.O.R.R. 374.

${ }^{3}$ Switching to sidings is reckoned on a cost basis. VI J.0.R.R. 23.

- $1 / 86 \mathrm{ff}$. 
cess to a large number of business premises in London which it did not previously have. The latter line applied for an order to compel the Grand Trunk to provide proper facilities for the interchange of traffic. It was urged by the Grand Trunk that in the event of such an order being made, on account of the greater advantages which would accrue to the Canadian Pacific under such an arrangement, that it (the Grand Trunk) should receive much the larger proportion in the division of rates for the traffic exchanged -

much greater than that which would be a fair remuneration for the mere service rendered in the transportation of cars over this branch, and its London terminal lines and the loading and unloading of the same.

The Board rejected this view and declared that "reasonable compensation for the services and facilities furnished" should determine the division of the joint rates and

not by reference to the magnitude of the business of the company or the other at particular points, or the respective advantages which each can offer to the other there, or a comparison of the loss the one is likely to sustain, with the gain likely to accrue to the other.

The principle laid down here entered into the decision of the Board in the Interswitching Rate Case, ${ }^{1}$ where the Canadian Manufacturers' Association' complained that the railways absorbed switching charges at competitive points, but added it on at non-competitive points. The Board ruled: (1) that tariffs related only to points on a company's own line; ${ }^{2}$ (2) that where delivery was made through the switching facilities of a second company, a reasonable additional rate might be collected; (3) that while the company, carrying such traffic for the long distance should not be obliged to absorb the whole of the switching charge, it might not necessarily be debarred
$14 / 214$.
2 Following 12 I.C.C. 556. 
from doing so, providing this did not involve unjust discrimination or preference, and that in case of competition if it did so absorb charges the charge of discrimination would not lie; (4) that two companies where interswitching was involved, might be required to treat such traffic as joint traffic and the joint rate might be less than the sum of the two rates, and that each of the companies might be required to accept less than its full rate.

This opinion is set forth at some length because it summarizes a number of principles and positions that the Board has developed in other cases. The crux of the matter lies in the view that interswitching is to be treated essentially as joint traffic and to be passed upon on the basis of the principles there developed. ${ }^{1}$ These have been already discussed, and it is only necessary to remember that a higher charge for traffic involving joint service was justified on a basis of increased cost. The only difference is that the costs of interswitching are more capable of being accurately determined. Subsequently a standard tariff of tolls was filed. This tariff has a maximum and minimum level between which rates are determined on the basis of distance and tonnage. ${ }^{2}$

In 1916, in a reconsideration of the General Interswitching order, it was held that it is not a mandatory order requiring interswitching wherever possible, but merely a regulative order fixing tolls to be charged when the service is performed. A railroad if it choose may cart goods from an industry located on a siding off another railway company's line. Cartage equalization and the substitution of cartage for interswitching are permissible so long as the carrier complies with the obligation to observe equality in its treatment of shippers. That is, if it grants free cartage to one industry because it has a siding off a

${ }^{1}$ Cp. 10/139.

${ }^{2}$ Circulars and General Orders, issued by the Board from its inception to October, 1912. p. 480. 
rival road, it would not be justified in refusing free cartage to another industry which possessed no siding. ${ }^{1}$

The Board has decided 'that interswitching in connection with a stopover before the final destination is reached does not come within the scope of the general order. This naturally follows from the holding that a stopover for milling purposes is in itself a privilege and may not be ordered by the Board. ${ }^{2}$ The only way in which this may come before the Board is where the railways have voluntarily granted the privilege and discrimination has been alleged. ${ }^{3}$ Certain grain elevators in Winnipeg alleged undue charges against the Canadian Pacific Railway for the delivery of grain from the Canadian Northern lines on the stopover privilege. ${ }^{4}$ The Board said it would be unfair to require the carrier. to absorb part of a switching charge in this case, for it might dissipate the one cent per hundred pounds which it receives for granting the stopover privilege. Similarly, in the Cartier Stopover Case, where grain cars have been consigned to Cartier "For Orders," the Board said that this was a substantial service entitled to fair remuneration. ${ }^{5}$

The use of cost data to determine the relative reasonableness of tolls permits of another application. It has been shown that where the carriage of traffic involves a special service a higher charge has been justified. The Board has also had to deal with cases where a reverse condition was established, that is, where the traffic does not require the usual amount of care and attention. The principle that where these conditions develop a charge lower than the standard level is fair and just has been estab-
$111 / 271$.
$211 / 101$.
314 C.R.C. 346.
$4 / 259$.

4/256. Cp. Rat Portage Lumber Co. vs. C.N. Ry., 6/215; Atikokan Iron Co., Ltd., vs. C.P. Ry., 7/257; Montreal Produce Merchants' Association vs. G.T. \& C.P. Rys., 5/224; also, Application of Fruit Growers' Association of Ontario for stoppage-in-transit privilege for fruit, 8/275, and Application of the Board of Trade, Montreal, for milling-in-transit for corn, file 12384; stopovers at Government storage elevators, 11/171. 
lished. The issue was raised in the application of the Winnipeg Free Press for a rate on newspapers lower than the express rate on ordinary merchandise traffic, to apply on papers going beyond the territory covered by a special zone rate. ${ }^{1}$ The Board reduced the rate to one-half merchandise rates, basing the reduction upon a distinction between this phase of traffic and ordinary merchandise traffic: -

Newspaper traffic differs in a great many ways from the ordinary merchandise traffic. The newspapers are taken down to the train at the last moment and put on by agents or employees of the newspapers. There are not the expenses of delivery and collection which apply to ordinary merchandise traffic, and there are not the waybilling expenses which also apply to the ordinary merchandise traffic.

The reduction of rates in this instance thus lies squarely upon a cost-of-service basis. Moreover, the order was made general and may therefore be accepted as a general position of the Board.

This completes the discussion of cost elements, arising out of differences in the conditions under which the traffic is handled, which justify discrimination in charges for carriage. The wide range of application, which a study of these cases reveals, indicates the importance of the cost-of-service principle in rate-making in Canada. This will more clearly appear when its use is compared with the employment of the value of the commodity as a test of reasonableness.

$\S 7$. Quite in contrast to the fullness with which considerations of competition and cost have been treated by the Board is the relatively slight stress that has been placed upon the principle that the value of the commodity affords a basis for rate adjudications. This in itself does not indicate of necessity a predilection, on the part of the Board, for the cost principle. As a quasi-judicial body it

$$
17 / 287 .
$$


ordinarily must pass upon the issues as they are presented. It could hardly go outside of the record, unless the case warranted a special investigation, to seek factors upon which to base its decision. However, this does not dispose of the comparative absence of the value of the commodity principle in Canadian rate litigation, but rather points back to the nature of the rate disputes themselves. A glance in retrospect at those which have been considered reveals that they are largely concerned with the broader issues involved in rate regulation. There have been relatively few cases where the issue has lain between competing commodities or commodities in different stages of manufacture. These are cases where a very slight difference in tolls on products not unlike or which may be substituted for each other, might put competing manufacturers at a disadvantage one to the other. In cases of this sort the value of commodity principle becomes especially serviceable as a measure of reasonableness to prevent undue discrimination. To the comparative absence of cases where the principle would be useful, may be attributed the secondary position, which in point of fact, it occupies.

In a study of rate theory, however, it is not necessary to rely upon a multitude of cases to determine the general attitude of the Board to the principle involved. It may fairly be said that the Board has given due weight to the value of the commodity principle when it has been urged as a factor in the case. It has laid down that it is "elementary that in order that the cheaper goods may be carried any distance at all the classification must be arranged according to the ability of the various articles to bear their share of the cost of transportation, so that luxuries and things which move in comparatively small quantities are rated higher than the indispensables." This amounts to saying that goods of high value shall pay a greater rate for carriage than goods of low value. In a few cases ap- 
propriate to the use of this principle it has been made the controlling factor. In the application of the Blaugas Company for a commodity rating on blaugas in cylinders the company stated that it wished the same rating as that granted to gasoline with which it enters into competition. ${ }^{1}$ The Board declared that the justification of the rating given to blaugas by the railways as compared with gasoline must rest on the value of the commodities. A comparison being instituted, it was shown that the rates on gasoline were a higher percentage of the value of the article than the rates on blaugas were to the value of that commodity. On this finding the Board declined to disturb the rate. "There is no question," it said, "that the pressure of the freight rate is much less in the case of blaugas."

In the case of a rate of forty cents a hundred on alfalfa meal from Enderby, British Columbia, to Duncan, British Columbia, it was shown that the rate was very much higher than that on oil meal and other grain products. "As feed of low value and entitled to low classification," the Board calculated a rate on the sum of the locals amounting to thirty-two and a half cents per hundred, which was scaled down to a through rate of thirty cents a hundred. ${ }^{2}$ In an application for the reduction of rates on gravel from Fonthill to Toronto, the value of the commodity was a factor in the decision, the Board observing that "sand is a commodity which has a low value in a comparatively large bulk. Consequently it cannot bear as large a part of general costs as other more highly valued commodities." 3

The general express investigation affords another illustration of the Board's attitude to rates based on the value of the commodity. ${ }^{4}$ Among other tariffs the express classification contained a tariff of valuation charges on merchandise which was justified by express companies as an insurance charge. The Board concluded the valuation ${ }_{16}^{6} / 339$. ${ }^{2} 11 / 109 . \quad{ }^{3} 10 / 120 . \quad{ }^{4} 6 / 295$. 
charges were "really an extra toll for transportation demanded by the carrier on account of the increased responsibility it assumes," and justified the principle of the levy in the following terms: -

There is nothing unfair in the carrier asking to be paid more for carrying a 100-pound package one hundred miles, which is worth $\$ 1000$ than would be asked for the same package worth but $\$ 20$.

These cases exhibit the general principle the Board has accepted where value considerations have been urged. Moreover, as between articles of value of the same general nature, as indicated, it has held that a commodity conceded to be a luxury may fairly be given a higher rate. This teaching obviously is applied in the demand of the Cut Glass Importers, Limited, for a reduction in rating from double first class to first class. ${ }^{1}$ It was shown that the latter was the rating placed upon chinaware. The Board said that cut glass was not in such general use as china, it was an article of luxury and could stand a high rate. Similarly in the Ledoux application ${ }^{2}$ for a carload rating on cigars one of the factors in the refusal was the view that cigars were a luxury and if the application were granted, -

it might well be contended that other luxuries now rated as first class should receive similar reductions in rates.

The Board has not, however, essayed the highly interesting task of working out a sumptuary principle of rate-making. These opinions are cited because they are examples of the general position that the railways may assess articles of value upon that basis without regard to the cost of carriage.

There remains to be considered in this connection the rate relationship between commodities in different stages. of manufacture. While it is true that in many cases there

112 C.R.C. 10.

2 7/185. Cp. rates on cream, 8/11; Seaman Kent \& Co. vs. C.P.R., 7/255. 
are sharp differences between the form of the raw material and the manufactured and partially manufactured goods, in other cases the only change deemed pertinent to rate-making has been a change in value. Consequently it has become the basis of defending any increased charge which might be levied. The prevalence in Canada of the milling-in-transit privilege has undoubtedly reduced the number of appeals under this head. Few cases have come before the Board and in most instances the value of commodity principle can only be inferred from the holding; rarely has it been explicitly stated.

A notable decision occurred, however, in regard to the classification of tin plate and metallic shingles and sidings. This question was before the Board twice, and on the latter occasion the former decision was reversed. For over ten years tin plate was classified in the seventh class, while metallic shingles and siding paid the higher rate of fifth class. In 1905 the railroads, claiming that this classification was a mistake, advanced the finished product to the fifth class also. Thereupon the Canadian Manufacturers' Association appealed to the Board against the change, and their appeal was allowed, on the ground that the former rate had been in existence many years and that the railways had not rebutted the presumption that the arrangement was reasonable. ${ }^{1}$ While basing the judgment upon the long continuance of the rate the Board said the arrangement was really illogical: -

Having reference to the nature of the commodity in question if the work of classification was now being undertaken for the first time these articles would naturally fall within the fifth class. $^{2}$

Or, as subsequently interpreted, the Board's position on this occasion was that if the railways chose to be illogical, without causing undue discrimination or hurting other interests, there was no necessity "for the Board's inter-

$$
{ }^{1} 4 / 148 \text {. } \quad 2 \text { Cp. 9/271. }
$$


vention as a mere arbiter of logic." It was precisely on the point of undue discrimination that the question was raised again. ${ }^{1}$ Metallic shingles and siding are largely used in the construction of grain elevators and a manufacturing industry had grown up at Winnipeg despite the disadvantage of importing raw material at higher rates than the finished product. In 1909 this interest appealed to the Board to equalize rates on the manufactured commodity as against that charged on the unmanufactured material. Holding that the establishment of an industry at Winnipeg had materially changed the situation, the Board rescinded the former order. In arriving at this conclusion, the Board naturally discussed the principles that obtain in the classification of raw and finished goods:-

It is a natural trade condition for manufacturers, conditions of capital and demand being satisfactory, to carry forward the raw material to the point most economically adjacent to the centers of demand and there manufacture it. Normally this means that the long haul of the raw material is at a low rate, while a higher rate is on the finished material from point of manufacture to point of destination. Sometimes both the raw and finished material may be in the same class. To find the raw material classed higher is abnormal.

It will be noted that the analysis is not carried beyond "natural trade conditions," so that the justification of a lower rate upon unmanufactured material cannot be explicitly assigned as being due to a change in the value of the commodity.

Similarly, in an application of the Transportation Bureau of the Montreal Board of Trade for an order to adjust the rates on corn and cornmeal so that the combination rate on corn milled at Montreal under the milling-intransit privilege to St. John should not exceed that available to any Ontario mill, ${ }^{2}$ the opinion of the Board is only logical on the supposition that it is using value as a 
criterion. The Board said that the application was impracticable because, in one instance, -

while the mileages may be the same there is in the first place a relatively short haul of the raw material and a long haul of the finished material, while the conditions differ somewhat in the case of the product milled at Montreal.

Moreover, the fact that in both these instances the Board disclaimed any intention of directing trade development, strengthens the conclusion that difference in value between the finished and unfinished commodities was the underlying consideration. Such a position is in harmony with the Board's general attitude to value as a factor in rate-making, as it has been set forth.

The relatively unimportant part that the principle has played is apparently due, as an examination of cases where the factor was considered suggests, to the nature of the cases adjudicated, rather than to any unwillingness on the part of the Board to recognize it as a proper basis for rate-making. 


\section{CHAPTER VIII}

\section{RATE THEORIES AND PUBLIC POLICY}

§ 1. The Dominion Parliament in defining the duties of the Board laid upon it the obligation of disallowing "any tariff or any portion thereof" which it considered to be unjust or unreasonable. This grant of power naturally grew out of the fact that the Board took over the general powers of supervision, subject only to a right of appeal, which general acts had formerly vested only in the Privy Council. This general clause has acted as a dragnet for bringing rate grievances to the consideration of the Board that could not well be brought either on a charge being unreasonable in itself or on the basis of undue discrimination. In accord with the legal canons of interpretation, it has been construed with reference to the text of the act, so that the additional relief that it affords has been more illusory than real. In general, cases argued on this basis arise out of the refusal to continue some rate privilege which it was in the discretion of the railway to grant or withhold in the first place. As these privileges usually touch the development of industry and commerce the Board in passing upon them must frequently base its decision upon the broader consideration of commercial policy. On this account it has been deemed wise to bring together various decisions of the Board which relate to commerce although all of them do not rest on this section of the act. In general these decisions may be viewed from the standpoint of their effect on industry and traffic, or in other words their effect upon industrial development and more specifically their effect upon the business of transportation itself. 
It is not necessary here to delve into the considerations that lead the railroads to make rates sufficiently low to permit the development of industries along their lines. The interest lies in the attitude of the Board of Railway Commissioners to these developmental rates. In a young country, such as Canada, where the conditions are seemingly ripe for industrial development at many points, the question is of the greatest importance. The ability to persuade industrial or commercial interests to center at one point in preference to another begets rivalries even more acute than those engendered in the struggle to maintain that which has been already won. Moreover, this struggle for initial advantage is aggravated by real estate speculation, a phenomenon which usually companions any attempt to develop a place into an industrial or distributive center. It is therefore not a matter for surprise that inconcurrencies of judgment should frequently develop between a naturally sanguine local interest and the more cold-blooded traffic official. Under the circumstances the obvious course of action is to appeal to the Board, and it. does not require any great gift of imagination to foresee the responsibility that would accrue if the Board had jurisdiction over the granting of developmental rates.

As a matter of fact the Board has repeatedly declared that it does not consider it within the scope of its jurisdiction to equalize the costs of production as between different markets or producing points. ${ }^{1}$ It has defined its attitude as holding the balance true between shipper and carrier with respect to the particular freight movement in question and without regard to its larger social effects. ${ }^{2}$ In denying the application of the Canadian Oil Companies, Limited, for a reduced rate on oil from Petrolia, Ontario, to Winnipeg, Manitoba, the judgment Commissioner said: -

$16 / 340,7 / 212,7 / 246,10 / 124,10 / 345$; VI J.O.R.R. 267; 5/231.

$27 / 210$. 
While personally I have sympathy with the "territorial sectarianism" which desires industries to be established in one's own country in preference to a foreign country, the matter of sympathy affords no justification for the reduction asked.1

This position the Board has decisively taken when confronted with arguments maintaining the justice of manipulating railway rates in the interests of commercial development. Thus, to cite another instanee of a similar nature, when the Farmers' Dairy and Produce Company applied for a through rate for the carriage of milk for delivery to a connecting express company in the United States, the Board overruled the Canadian Pacific Railway's objection that it did not wish the traffic except at full tariff tolls but suspended operation of the order pending proof that a toll had been agreed upon with the foreign carrier. "Commercial considerations," it said, "are entirely outside of the question as the Board should consider it." 2

Its more general application to industry appears in several cases, two of which came before the Board in the first year of its existence. These opinions are important because of the wide range of principle which they cover, and taken together they serve to define the general position of the Board to industrial development. A clause in the railway act provides that the Board may make concessions from current rates on materials for the construction and the machinery for the equipment of new industrial plants. The Canadian Freight Association, on behalf of the railways of Canada, applied for a general order from the Board to give effect to this privilege. ${ }^{3}$ They alleged it was customary to grant a reduction of twenty-five per cent on such freight. The Board interpreted the clause as being introduced to give a certain elasticity to the Board's decisions in regard to discrimination, but declared that if given general effect it feared it would open the door to discrim-
$17 / 210$.
${ }^{2} 17$ C.R.C. 106.
3 $1 / 69$. 
inating rates between shippers of the merchandise affected. ${ }^{1}$ As a question of "very considerable magnitude and importance" the Board denied the order, holding due effect would be given to the clause by a

separate and distinct application in such case, so as to judge of the effect of its order upon other industries, shippers, and dealers.

On the same day it rejected an application of the Grand Trunk Railway for permission to continue a difference in the rate of freight on bituminous coal of ten cents per ton in favor of manufacturers as compared with that charged to dealers or consumers. ${ }^{2}$ The company claimed that certain manufacturers would be unable to pay the higher rate and carry on business successfully. The Board refused to attach weight to this consideration:-

Even if proved, the reduction could not be allowed. The allowance of a reduction in the freight rate of any article of merchandise to one class of shippers, and the refusal of the same rate to another class is unjust discrimination.

In the complaint of the Board of Trade of Portage la Prairie against the rates given to the jobbing houses of Winnipeg which enabled them to "scoop the business" of distribution at the expense of other towns, the tariffs were disallowed as unjustly discriminative. ${ }^{3}$ In this case the evidence showed that the Canadian Pacific issued a series of special freight tariffs and that no one outside of those whose names appeared upon a certain list of wholesale merchants could ship goods at the rates mentioned in these tariffs. The list was furnished to the railway. The disallowance of this advantage hit the Winnipeg interests quite severely and they brought the issue before the Board again in the Winnipeg Rate Case. ${ }^{4}$ The Winnipeg Jobbers' Association applied for the restoration of the same rates out of Winnipeg as had hitherto existed, on the ground that the railways must show cause why a rate
${ }^{1}$ Cp. 11/259.
2. $1 / 70$.
$34 / 265$.
$4 / 263$. 
presumably reasonable should be advanced. The Board denied the application, holding that no presumption attached because the local rates substituted on the order of the Board could not properly be compared with the balance of the through rates which preceded them. In this instance it was clearly recognized that the aim of the railway was to assist in establishing Winnipeg as a distributing center.

The real issue, so far as this study is concerned, however, is the degree to which the railways may exercise discretion, in granting commodity rates. These cases simply indicate the limitations of a general nature which the prohibition of undue discrimination places upon the railways. In brief, the railroads may not grant special privileges to manufacturers as distinct from other groups of shippers, nor may they grant special privileges to certain cities or towns where it can be shown an injury is thereby worked to other towns and cities not so favored. ${ }^{1}$ The positive side of the Board's decisions remains to be developed, and that must be considered before final conclusions may be drawn.

While the Winnipeg Rate Case indicated that the Board would not validate rate preferences adventitiously acquired, yet the general question of the Board's powers in regard to control over commodity rates was not determined. That question was reserved, for the Board recognized the technical nature of the factors upon which its decision had turned but gave a lead as to its views with respect to the really vital issue in the case. In discussing the argument of the counsel for the applicants the Chairman of the Board said: -

Mr. Chrysler takes the position that the Board cannot order the railway company to grant every locality and every place a commodity rate. As to that, I am rather inclined to the view that his contention is right. I do not finally dispose of it at the moment, but it seems to me off-hand that it is the railway compa- 
nies that have the right to frame their tariff. The board does not frame the tariff, and the public does not frame the tariff; the statute gives the railway company the right to frame its tariffs. And while the statute gives certain control over the tolls to the Board of Railway Commissioners, it does not by any means put the Board in the position of being able to in all cases control the carrier in the fixing of his tolls. I am inclined to the view that the carrier has the right under the statute to name the localities as to which commodity rates may be granted, but as to that I do not express any conclusive opinion.

This informal opinion hardened into a definite holding in the Brampton Commutation Rates Case. ${ }^{4}$ Brampton is 21.1 miles from Toronto, Oakville is 21.14. To the latter point the Grand Trunk Railway sold commutation tickets much below the regular rates. The same privilege had been extended at one time to Brampton, but was withdrawn, in part because of the opposition of the merchants of the town. Later a resident of Brampton applied for an order to direct the railway company to sell him tickets at the same rate as citizens of Oakville could obtain them. In refusing to grant the order the chairman set forth the policy of the Board in clear terms:-

The act recognizes the right of a railway to discriminate between points; it is only unjust discrimination, or undue preference that the company is required to clear itself from....2 It may be that Oakville has to a small extent profited by these reduced fares; it may be that Brampton would profit to an equal or greater degree, if they were in force between Toronto and that town; but the question is whether Oakville has profited at the expense of Brampton, and I am of the opinion that such has been shown not to be the case.

This decision was given in 1908. Two years later the city of Toronto and the town of Brampton revived the question, and it again came before the Board in a general form: ${ }^{3}$ Comparisons were instituted between the practice of the railways at Montreal, and it was also shown that
$14 / 245$.
${ }^{2}$ Cp. 10/197 ff.
$36 / 166$. 
commutation rates were in force in and out of Toronto from forty-two stations. The Board again denied the application on the basis established in the previous opinion, and reiterated the position there assumed:-

We are not of the opinion that because a railway company or railway companies operating into and out of Montreal give commutation rates, therefore they are compelled to give them into and out of Toronto. Why particularly Toronto? Why not Hamilton, why not London, why not Kingston, why not Winnipeg, and every other city throughout the whole Dominion? And why stop at cities? Why let the cities discriminate against the towns? Why not into and out of every town? Why should rates be cut into and out of cities and not into and out of towns? And why, forsooth, stop at towns? Why not the villages? And in the end it would result in their discriminating in favor of certain localities, cities, towns, or villages, or it would result in cutting down the lawful railway fare to six-tenths of a cent between all the stations in Canada.

This position the Board has consistently maintained, and has denied applications for commutation rates from St. Hyacinthe to Montreal and from Lachute to the same city. ${ }^{1}$ In the Telegraph Tolls Case the Board declared that "the ultimate test of discrimination is to be found not in a difference of rates, but in the question whether as a result of this difference an injury is worked to an individual or a locality." 2 This principle received application in connection with a special freight tariff filed by the Canadian Northern Railway from Toronto to Regina on tank and steel structural material. The Imperial Oil Company, planning to erect a refinery at Regina, desired to fabricate the steel materials necessary at their plant in Sarnia. They approached the Père Marquette Railway to secure a special rate from it of seventy-five cents to Regina. This was promised, but when the material was ready for movement the Père Marquette declined to maintain the rate. The Canadian Northern Railway then filed a special tariff

117 C.R.C. 88; 9/295.

2 VI J.O.R.R. 40. 
of $58 \frac{1}{2}$ cents from Toronto applicable only to shipments originating at Sarnia. This rate, plus the $16 \frac{1}{2}$-cent established rate from Sarnia to Toronto, would give the required 75-cent rate. Western interests objected, but the Canadian Northern Railway pleaded that it needed the revenue, some five thousand tons of freight being involved, and sought to sustain the tariff as a competitive freight tariff. The Board ruled that Canadian lines had the right to differentiate any rates only to the extent necessary to meet the advantages enjoyed by one company over the other that a shorter mileage created. Carriers could not go further. Pointing out that there were plants at Winnipeg the Board said: -

While this is true, no new tariff structure can be justified, the effect of which would be to favor the Eastern fabricator of iron and steel as against his Western competitor in the Western market. ${ }^{1}$

The opinions of the Board in the matter are set forth with some length, not only because they exhibit the development of a policy, but also because, however heroic and irrefragable the logic may appear, even with the limitations made in the last case considered, it must be apparent that under these decisions the railways may exercise very considerable discrimination in the granting of special favors. The latitude of the railways is recognized by the Board: -

Now, if the railway companies have exercised the discretion that the statute has conferred upon them in naming these points to which they will grant commutation rates, they are within their rights, in naming those or any other points they choose. That discretion is not to be interfered with unless it operates unjustly or undue preference or discrimination follows. . . . But after all it must be left largely to the good sense of those who are in the control of the railway facilities as to what services can be afforded and, within reason, what the tolls shall be. 
Naturally this holds even more truly if the connection between certain desirable social or industrial conditions and enhanced railway returns are somewhat remote. Thus, in regard to movements of gravel to points in the counties of Lambton, Kent, Essex, and Middlesex, Ontario, an appeal was made to the Board to obtain low commodity rates so as to enable the many municipalities affected to proceed with the work of general road improvement at a reasonable expense. The Board remarked that the great public necessity of improving the highways in the interested counties had been made abundantly clear, as well as the great corresponding benefit that good roads would mean, not only to the farmers in the first instance using them, but also to all kinds of industry including the railways. Nevertheless, the Board found it impossible to order lower rates for the railroads. "It is impossible for the Board to say that the rates proposed by the railways on gravel are excessive or unfair. The Board is bound to go this length before interfering." 1

It need scarcely be pointed out that the Board will not order a developmental rate. The point was tersely put by the Board in refusing an application of the British Columbia News Company, Limited, for a low rate on magazines and periodicals out of Vancouver: -

It is not the Board's function, as delegated by Parliament, to make rates to develop business, but to deal with the reasonableness of rates either on complaint or of its own motion.?

The holdings in the China Clay Case and in the Edmonton Clover Bar Company Case, already discussed in another connection, indicate clearly the Board's limitations here. If the railroad is guilty of an error of judgment in not granting a developmental rate, the Board cannot rectify that error. The railway may suffer; the public must. It is a "question for the railway company itself to decide." 3

$$
111 / 147 . \quad 27 / 35 . \text { Cp. } 3 / 149 . \quad 317 \text { C.R.C. } 95 .
$$


Thus the Board said with respect to the effect of the Panama Canal upon water rates to the West:-

There is no doubt whatever but that rates which the railway companies may make for the purpose of enabling manufacturers and shippers in Ontario and eastern Canada generally to continue to do business as in the past appear to be a national necessity; whether such rates are or are not put in, is a matter entirely for the railways. They cannot be ordered by the Board.1

Another phase of developmental rates has come before the Board at various times that is worthy of notice; that is in cases where certain commodities may be used for several purposes, but where a certain use requires, if the industry is to develop, lower rates than is generally granted. For instance, the Board in dealing with rates on cream was urged to give a lower rate in cream used for butter-making than for domestic use. In the Express Case this was granted, but the matter coming again before the Board a uniform tariff was authorized. The Board, in reconsidering the difficulties of a dual system of tariffs, decided that the question at issue should properly follow the early ruling of the Board that there should be no reduction in rates upon coal for manufacturing purposes. It gave judgment accordingly. ${ }^{2}$

In other cases the same disposition of the problem has been made. The complaint of the Western Retail Lumbermen's Association of Canada against an increase in carload minimum on brick from 40,000 to 50,000 pounds over lines in Western Canada was dismissed. The applicants set out that the demand in small towns for brick was very light and that a 50,000 minimum would mean it would take more than one season to dispose of a carload. The Board answered that the freight rate was only one item in the shipper's cost and a railway company was not called upon so to adjust its rates that the shipper would always be able

$111 / 184$.

$8 / 11$. 
to carry on his business at a profit. Similarly Messrs. Hay \& Company, of Woodstock, were unable to secure a reduced minimum on logs used in manufacturing handles and veneering. ${ }^{1}$ For the same reason the Shingle Agency of British Columbia was not permitted to load a complement of nails with shingle shipments. ${ }^{2}$

With respect to the milling-in-transit privilege, the Board has repeatedly held that it is unable to order that it be granted unless discrimination can be shown. It may only come within its jurisdiction if it discriminates against anybody. "After all, the milling-in-transit privilege is just what it says. It is a privilege and not a right." 3 Thus, to eliminate discrimination, the Board required a millingin-transit rate to be given at Sudbury in connection with the grain movement, but it held for there to be such an extension the privilege must have been granted "at other points under exactly the same conditions and circumstances and exactly for the same industry." Under this ruling a milling-in-transit rate was refused to the Sudbury Brewing and Malting Company. Although a milling-in-transit rate was granted for grain offal from flour mills, it was refused to the brewery. In the case of the flour mill, the Board said, the by-product obtained it because the main product had it, the greater including the less, but in this instance the applicant asked for transit on the by-product when there was no transit privilege on the main product - the beer. Similarly, the Board refused to order the railroads to grant the stopover privilege to the Shingle Agency of British Columbia, although in Eastern Canada lumber is permitted to be stopped in transit for dressing, resawing or sorting and reshipment on a milling-in-transit rate. ${ }^{4}$ The clue to the strictness with which discrimination is construed in these instances is to be found in opinion of the Chief Commissioner in the Sudbury Case: -

1 VI J.O.R.R. 480. See ante, p. 158 ff. ${ }^{2}$ VI J.O.R.R. 457.

$311 / 101 \mathrm{ff}$.

- VI J.O.R.R. 489. 


\section{CANADIAN RAILWAY RATES}

A the brewer is discriminated against why not the manufacarer of sugar beets or starch? Why should not the sugar beet manufacturer get the special privilege on his dried beet pulp which may be used for feed purposes, or the starch manufacturer get the low rate on the by-products of the corn which he has brought into his factory, and which again, may be used for the purposes of feed? 1

In brief, to grant the recognition of discrimination between different businesses would carry the privilege to such a point as to make inroads on the revenue of the company as well as to take a large discretion out of the power of the railway manager. The reasoning which led to the rejection is closely analogous to that employed in the Brampton Commutation Rates Case. ${ }^{2}$ On the surface some objection might be taken to the views set forth by the Board. It might appear that desirable social ends could be obtained by a somewhat broader interpretation of the act. Three objections, however, stand out. In the first place, the scope of the Board is corrective and amendatory. It has no general warrant from Parliament to act as Providence in the control of commerce in so far as it can be influenced by transportation costs. Secondly, if it exercised large discretionary powers of this nature it would tend to undermine the responsibility of the railway manager. Finally, even if it did have the power to order rates that would tend to equalize costs and thus to permit certain lines of industry to develop, it would be doing so at the expense of other industries: directly, in that favored industries would not be contributing their due share to fixed costs, and indirectly, by deflecting the flow of raw product to less advantageous uses. These undoubtedly are weighty reasons for the limited discretion assumed by the Board in problems of this nature. They are based, fundamentally, however, on a laissez-faire, pecuniary point of view. ${ }^{3}$
1.11/102.
2 Ante, p. 207.
3 Post, p. 224. 
Tariffs, it is true, may be ordered to be prepared in certain circumstances for certain routes as distinguished from the reduction or readjustment of existing rates. But the fact that the Board orders such tariffs to be installed does not necessarily prove that it is encroaching upon the carrier's right to initiate rates. Cases of this sort typically mean that the railway has failed to extend a rate of general applicability to a certain section of its line. Thus, when the Riverside Lumber Company, Limited, complained of the rates charged by the Canadian Pacific on lumber on its Weyburn-Lethbridge branch from Viceroy to Assiniboia, the Board held that once a line was opened for traffic, delay in installing general rates created unjust discrimination. ${ }^{1}$ The extension of a rate to eliminate unjust discrimination is quite different from ordering the installation of the rate in the first place, and leaves the railway's power in this latter respect quite intact. The great unregulated power of influencing the development of Canada which remains outside the scope of the Board's control in the hands of the railways will receive further consideration later. At this point it is sufficient to note that it exists.

§ 2. On the other hand, when the railways, of their own volition, have established a developmental rate, that rate comes within the scope of the Board's jurisdiction. It may not freely be withdrawn. Equities may have grown up under it which demand protection. "It is a well-established principle of rate regulation that where a business has been built up relying upon a particular rate adjustment an increase in this rate adjustment should not be made without amply sufficient reasons." 2 In The Sydenham Glass Company vs. The Grand Trunk Railway it was shown that bottles had been shipped from Wallaceburg to Toronto at lower than fifth class. ${ }^{3}$ Upon the rates being increased the company applied for relief to the Board.

$$
110 / 202 . \quad 28 / 45 . \quad 31 / 67 \text {. }
$$


Upon the representation that it could not maintain its position in the home market against foreign competition the advance in rates was disallowed. Similarly, when the railways increased the rate on split peas for export, the pea millers protested that the new rates were prohibitive and that they would lose the English market. ${ }^{1}$ The Board found reason to grant relief in the fact that the flour rate, which split peas had formerly taken, had not been advanced. The Board remarked that it was doubtful if railways should be permitted to continue a policy which, while financially preferable to them, did an injury to an important Canadian industry.

The position developed in these cases has been recently limited by the ruling in the complaint of the Nanaimo Board of Trade against the elimination of Nanaimo as a terminal freight-rate port. Nanaimo had had the advantage of the terminal rate for a long time. It was admitted that freight movements to Nanaimo were relatively not declining. It was accepted also that when granted the same terminal rate as Victoria there were differences between these points in respect of ocean tonnage and water competition. Nevertheless, the Board held, notwithstanding these facts, that the railway company was entirely within its rights in abrogating the arrangement because it had the discretion to mèet or ignore, as it chose, water competition. ${ }^{2}$

Moreover, if a developmental rate be granted and it serve its purpose of establishing a prosperous industry, the Board will permit normal rates or at least rates higher than those first granted, to be reëstablished from that point. This is obviously the teaching of The United Factories, Limited, vs. The Grand Trunk Railway. ${ }^{3}$ In this case the railway companies had granted a three-cent rate upon logs upon condition that the product should be delivered for shipment by its line. Later the railway advanced
$11 / 70$.
2 VI J.O.R.R. 12.
3 1/69; VI J.0.R.R. 201. 
the rate to four cents, subject to the same condition. The ordinary rate was seven and one-half cents. The complainant alleged that the volume of business had largely increased, and contended that instead of an increase they were entitled to an even lower rate. The Board rejected this plea, holding that the low rate was a temporary expedient to develop traffic, and that the new rate was neither unjust nor unreasonable. Probably in this instance the disparity between the original rate and the ordinary rate on logs influenced the Board, for in cases of this nature in the absence of other data the Board has relied upon comparison of other rates. When the winter export rate on butter from Montreal to St. John was advanced, while admitting the presumption of reasonableness that attached to the old rate, the Board justified the advance on the lowness of the rate per mile and the nature of the service. ${ }^{1}$ In an advance on the rates on stone from Stonewall to Winnipeg, where the railways had agreed to protect the rate, the Board disallowed the increase, stating that its opinion was strengthened by a comparison with the rates charged on the same traffic from points outside of Toronto. ${ }^{2}$

On the other hand, the Board will not permit a carrier unreasonably to increase the rate to shut out competition. This was the point of the Stoy Case, ${ }^{3}$ where the Grand Trunk endeavored to collect the local rate from the American boundary on crude oil:-

The reason given for this attempt was not that the joint rate covered by the joint tariff was unreasonable or unprofitable to respondents. It was admitted that the local rate attempted to be established in place of the share of the joint rate was excessive, and intentionally so. It was established, so it was stated in the evidence, "to keep out American oil by putting up these rates." This is illegal.

Conversely, the Board will not compel a reduction in rates where a change in the customs' tariff exposes an in-
$14 / 228$.
$21 / 73$.
3 $5 / 211$. 
dustry to foreign competition. In the application of the Canadian Oil Companies, Limited, for a reduced rate from Petrolia to Winnipeg, ${ }^{1}$ it was alleged that the advantage of the Kansas refiners was so great that they could "eliminate the applicant companies from competition in the Canadian Northwest." It developed, however, that this advantage in part grew out of the removal of the duty by the Canadian Parliament. The Board said, "It does not fall within the scope of the Board's powers to reduce a rate because a removal of customs duty has created a keen competition." In brief, the position of the Board is that the railways may lower rates for developmental purposes at their own discretion, so long as there is no undue discrimination, but that having lowered rates they may not be advanced, unless water competition is a controlling factor, except upon proof that there will be no injury to business that has grown up under the reduction. Rates raised merely to shut out competition are illegal.

$\S 3$. In the rate decisions that have been considered up to this point the issue has lain between public and private interests; the former as represented by shippers or consumers, the latter by the railways themselves. It is obvious, however, that cases may occur where the interests of the public are not affected at all, or if affected only in an indirect and remote way. These are cases that grow out of inter-carrier situations. They may arise where a given body of traffic might be carried to its destination by several routes, and where it might be premised that so long as the traffic is not carried at rates unreasonably high to the public, or at rates unreasonably low for the carrier, it were a matter of no direct consequence by what particular facility it had been transported. There must be a sequence of indirect consequences, it is true, which in the final incidence would fall upon the public, but on the surface the 
same rates for the same service being assured the public interest ends.

Of a group of cases which disclose these conditions, both in their direct and indirect aspects, probably the most important is The Elder-Dempster Company, Limited, $v s$. The Canadian Pacific and Grand Trunk Railways concerning through traffic to the Pacific Coast. ${ }^{1}$ The ElderDempster Company, Limited, operated a line of steamships to the Isthmus and was engaged in carrying British Columbia freight via that route to Vancouver. It was thus actively in competition with the Canadian carriers for the long-haul Pacific Coast traffic. In pursuance of this competition it applied to the Board for an order requiring the railways to apply the established export tariff on goods shipped from points in Eastern Canada to Montreal, St. John, and Halifax for export to Vancouver and other British Columbia points. In holding that the application could not succeed, the Board said that it was a struggle between competing carriers to compel the railways to divert their long-haul westbound traffic to a short eastbound haul under a low rate without it being by any means clear that the shipper would obtain any material benefit.

In reinforcing this conclusion the Board drew attention to the fact that it had no control over the joint ocean-andrail rate, and that there was no guarantee that if the export rail rate were applied to the traffic in question that the through rate would not proportionately rise. Although the Board was anxious, it said, that the shipper should be allowed to avail himself of every available competitive consideration of carriage and every available route, there was nothing to show that in this case benefits would flow from the reduction sought. When this decision was handed down the Panama Canal was not open for traffic, and considerable weight was given to the fact that the Isthmus Railway might easily absorb the reductions by higher

$$
15 / 281 .
$$


rates. How, in view of the existence now of an all-water route, the Board would revise its findings can scarcely be predicted. In other cases it has expressed the opinion that water rates, being more highly competitive, tend to be self-regulative. ${ }^{1}$ In the face of this expressed opinion the contention that a reduction of the rates to the export level might mean no real benefit to the shipper is deprived of its force. Manifestly, if the issue were pleaded afresh under the conditions that now prevail, the Board would be forced to grant the reduction or dispose of the application upon other grounds than that employed on this occasion.

The same train of reasoning has been relied upon in other cases to preserve railway traffic coveted by a rival. There can scarcely be any doubt that it is a settled principle of the Board that where no immediate direct advantage appears to the public the Board will not lend its power to enable one company to compete more successfully with another. This is shown with particular clearness in an application involving the coal rates between Duluth and Fort William and Winnipeg. ${ }^{2}$ Coal moves at a $\$ 2.50$ rate from Fort William to Winnipeg on the Canadian Northern line, where it is a valuable back haul balancing grain shipments eastward. It may also move from Duluth over the Great Northern and Canadian Northern lines, though a $\$ 3$ rate naturally penalizes a movement from that port. In the event of its doing so the Canadian Northern's share of the joint rate is seventy-five cents. To secure part of this traffic the Great Northern wished to equalize the tolls between the rival ports, while allowing the Canadian Northern the same amount in the division of the through rate as before. The Canadian Northern refused to agree to this proposition because it would be exchanging a short haul from the boundary for the long haul from the head of the Lakes, and it came before the Board. The Board said that it was not a case of the Winnipeg consumer get- 
ting coal by a shorter freight route, nor did the application come from the people of Winnipeg supported by evidence to show that the Canadian railways were in default in transporting the commodity. It therefore denied the application, characterizing it as "a plain and selfish attempt by the applicant to use the Board to divert traffic from the lines of the respondent to its own lines."

The Muskoka Rates Case affords another example of the operation of the principle. ${ }^{1}$ In this instance the Canadian Northern was the applicant and endeavored to compel the Grand Trunk and the Canadian Pacific Railways to sell through tickets to places in Muskoka served by its lines. The failure to prove that the public was appreciably interested was fatal to the application:-

It does not seem to be a reasonable proposition that a railway company should be at liberty to use the act for the purpose of diverting to its line traffic that has been originated only at great expense and trouble by another railway or other railways without at least showing a great preponderance of convenience to the public. ${ }^{2}$

It is true that similar decisions have been made in similar English and American cases, so that there is nothing novel in the Board's conclusions. ${ }^{3}$ Yet there are certain indirect consequences that flow from this principle when applied to Canadian conditions, that demand consideration. The Board has not been altogether happy in the economic reasoning it has employed to support its conclusions. As a matter of public policy the desirability of retaining the transcontinental traffic to the railways may be assumed. In the Elder-Dempster Company application the Board based its refusal to grant export rates on the ground that the shipper might not profit if the reduction were ordered. The opening of the Panama Canal has changed conditions and cut the ground from under the decision, yet the ini-

17 C.R.C. 289. Cp. 4/254. ${ }^{2}$ Cp. 17 C.R.C. $422 .{ }^{3}$ Cp. 9/287. 
tial desirability to retain the long-haul traffic to Canadian lines remains. To go farther, the general assumption that a reduction of rates that will introduce to a given field a competing carrier will not affect the service, is scarcely tenable. The assumption denies the merit claimed for competition. While the rates as between competing carriers may remain at the same level, yet those collateral circumstances, the due harmony of which unite to produce good or better service, come within the scope of competition, and there is continuous rivalry between competing lines in this respect. The truth of this observation has been verified time and again with regard to passenger service, and is a scarcely less important consideration in respect to freight. A safer basis for these decisions, more in keeping with economic truth, might have been found in the frank recognition that the orders applied for in these cases would mean competition for the carrier affected, but that as it lies in the discretion of carriers to meet or ignore competition, it cannot be indirectly forced upon a railway by the Board.

Another aspect develops in the Muskoka Rates Case. The tourist traffic comes largely from the United States and enters by way of Buffalo and Niagara Falls. The Canadian Northern had lines penetrating the Muskoka region, but had no entrance into Buffalo. In so far as the decision deprives the Canadian Northern from sharing in the tourist trade with the other lines, it is manifest that it affords a valid reason why that company should endeavor to build or secure an entrance into Buffalo. Apparently only in that way can it secure the traffic that will enable it properly to utilize its Muskoka lines. In other words, the indirect consequence of this decision - and it holds equally with respect to the Coal Rates Case - is to stimulate competitive railway building to competitive points, although facilities already in existence may really be sufficient to handle the traffic. The final effect is an 
unnecessary duplication of facilities which leads in the long run to higher charges.

While in these instances the Board refused to consider the more remote economic consequences of its decisions, but confined itself to the immediate effects, it made a factor in the decision in each case of the absence of an appreciable public interest. This element appeared, however, as controlling in a late case ${ }^{1}$ of considerable importance, an application of the Canadian Northern for an order directing the Grand Trunk to interchange freight traffic at North Bay on an equality with the Canadian Pacific. It was argued on behalf of the Grand Trunk that the interest of the public must be established, and this was met by submissions of the Quaker Oats Company at Peterborough that they were suffering from a shortage of grain. It was further recognized by the Board that if the application of the Canadian Northern were dismissed the effect would be to oblige it to hand over to the National Transcontinental at Winnipeg or the Canadian Pacific at Port Arthur all traffic originating on its lines in the West destined to Grand Trunk points intermediate to the transfer tracks at Toronto. This the Board held would violate the established rule that the initiating company is entitled to the benefits of the long haul. "It would not be just," the Chief Commissioner said, "to the Canadian Northern to refuse the present application or to carry the principles on which the Muskoka Rates and Fort William Coal Cases were adjudicated to their logical conclusions. There are other questions which must be considered." 2 As the decision indicates, the application of the principle of public interest plus the principle that the initiating company is entitled to the long haul virtually overturns the holding in the earlier cases.

The acceptance of this point of view is eminently desirable. The conserving of the long haul to the initiating

1 March 9, 1916.

2 VI J.O.R.R. 7. 
company fulfills the conditions of fairness and at the same time prevents inter-carrier rivalry indirectly, but no less certainly, leading to a railway situation of public detriment. In keeping with this decision the Board granted the application of the London \& Lake Erie Railway Company for an order requiring the Michigan Central Railway Company to place it on the same basis with respect to traffic arrangements as the London \& Port Stanley Railway Company. ${ }^{1}$ Similarly when the general inter-carrier situation in 1916 led to the cancellation of a large number of joint tariffs, the Board promptly ruled that joint rates must be given by both the Grand Trunk and Canadian Pacific to Canadian Northern points. ${ }^{2}$ In like manner the Canadian Northern must maintain joint tariffs between its line and proper points on the other two systems. If such cancellations were allowed the effect would have been to make traffic move between points affected on the sum of the locals. This phase of rate regulation has been dealt with more fully under the discussion of joint rates. ${ }^{3}$ The significance of the large number of cancellations, however, was that it was a phase of inter-carrier rivalry. The prompt action of the Board indicated that it would not permit the public interest to suffer in this manner.

Finally, several cases may be cited as further indication of the advance in point of view from the standpoint of public interest that has marked recent decisions of the Board. In 1906 the Board, under Chief Commissioner Killam, ruled that the Nelson \& Fort Sheppard Railway Company need not permit its equipment to leave its own line, and this precedent was followed by Chief Commissioner Mabee in 1911, who upheld the Grand Trunk in its refusal to grant cars for loading to Winnipeg via either the Canadian Pacific or Canadian Northern Railways. ${ }^{4}$

1 VI J.O.R.R. 89.

3 Ante, p. $167 \mathrm{ff}$.

2 VI J.O.R.R. 406; 11/253.

$6 / 359$. 
Under these decisions railway companies as occasion demanded refused to supply cars to be routed for destination off their own lines. But in the fall of 1916 complaints were made by the Edmonton coal shippers that they could get no cars for shipments to points on railways other than the railways upon which the mines were located. At Drumheller the Canadian Northern put an absolute embargo against loading any of its cars to points on the Canadian Pacific. The Board ruled: "Coal must be transported, and when necessary, existing transportation practices, rules, and rights must be made subservient to a real public emergency." 1 Working out the details of this principle it declared, "In cases where the long haul is enjoyed by the receiving instead of the originating line the receiving line must supply the cars." Similarly, when congestion of grain occurred in the Goose Lake district served by the Canadian Northern line, under additional powers secured from Parliament the Board ordered a substituted service over the Grand Trunk Pacific from Saskatoon without additional cost ${ }^{2}$ to the farmer. Finally, in January, 1917, when serious traffic congestion existed in Eastern Canada the Board compelled the railroads to rearrange their passenger schedules so that seventy-three engines and crews were released to move freight traffic. ${ }^{3}$ It will thus be seen that under the stress of traffic congestion and war conditions the Board has assumed considerably wider powers than in the past. In the course of assuming these powers old, established precedents have been set aside with considerable gain in the Board's elasticity of function. It must be recognized, however, that these powers have been exercised only under the pressure of emergency. They remain, nevertheless, available for use in future occasion of stress and difficulty.

In a couple of cases the right of a railway to grant a discriminating rate has been upheld on what is really a

${ }^{1}$ VI J.O.R.R. 440. ${ }^{2}$ VI J.O.R.R. 1, 3, 294, 312. ${ }^{3}$ VI J.O.R.R. 462. 
double basis, the right to protect traffic and incidentally to protect industry. These cases exemplify the principle that a low rate may be charged on raw material, if the railways will receive a return haul. In the International Pulpwood Rates Case ${ }^{1}$ this compensatory second haul from Canadian mills was held to be an important factor in the case. Similarly, when the Michigan Sugar Company, operating a plant at Croswell, Michigan, complained that the rate on sugar beets from points on the Chatham, Wallaceburg \& Lake Erie Railway was discriminatory as compared with the rate granted to the Dominion Sugar Company, whose factory was located at Wallaceburg, the railway urged that the low rate was granted in consideration of the higher rate on outbound products. ${ }^{2}$ It was shown that the products of the two factories did not come into competition and the Dominion Sugar Company paid for its sugar beets at a higher rate. The Board said that it was justifiable to take into consideration the relationship between the rates on inbound and outbound traffic, and decided that while there was discrimination it was neither undue nor unjust. ${ }^{3}$

A survey of these cases discloses the fact that the railways have very considerable power in manipulating rates for their own advantage. Thus power may be thoroughly justified from the standpoint of permitting the roads to develop traffic and thus of earning revenue, but it must be recognized that incidentally there goes with it considerable control over social development. It does not necessarily follow that a railway operating its lines to secure pecuniary results will at the same time procure the best social ends, or indeed consider them of much importance. It is a difficult problem how the discretion necessary to the railway manager may be conserved and yet permit social consideration to receive due recognition. As it stands, while the prohibition of undue discrimination puts a cer-
$18 / 273$. Cp. 9/275.
$26 / 205$.
${ }^{3}$ Cp. VI J.O.R.R. 203, 241. 
tain check upon preferential treatment, yet the interpretation of this principle that it must be shown that one point specifically profits at the expense of the other really in a large measure destroys its effective value. The power of the railways, for example, to hold back the progressive development of Brampton, while encouraging that of Oakville, is capable of wide extension, with correspondingly important results. There is really a great difference between "warm sympathy" and "cold justice," a fact that Canadian railway managers have not had to learn from Canadian politicians. A mediation between these two attitudes is needed. There is no reason under these rulings why whole districts might not be discriminated against in the same way, with the unfortunate social result that districts where industrial development means heavy traffic for the railways would receive every advantage that low transportation rates could give, while other districts, where conditions were not so favorable for the railways, might be subtly discriminated against, although from any other standpoint their development was just as important. There is no good reason why the Board should establish the general ruling that one line may refuse to sell tickets to points on another line with a view to protecting its own traffic, or may refuse to permit competitive rates. The subsequent rejection of the logic of this principle, when applied to freight traffic between the Canadian Northern and the Grand Trunk and the equitable solution of the problem, suggests that a better solution than that obtained might have been secured in the Muskoka Rates Case. Much sounder is the later position, as well as that established in the London Interswitching Rates Case, where the Board assumed jurisdiction and ordered interswitching at a reasonable rate between lines. The Muskoka Rates holding represents a rigid application of the individual competitive point of view; the later decisions, while conserving to the community the benefits of 
competition, limits its perils. They do not carry the logic of pecuniary competition to the point where it issues in a transportation situation of monopolized areas. The general reply which the Board itself has indicated to these observations ${ }^{1}$ is that the railways must be left free to execute their plans of commercial development in order that the railways may pay their way. This is true, but it really begs the question, for the very appointment of a Board of Railway Commissioners implies that certain curbs and restraints are to be laid on the railways in their pursuit of economic returns. ${ }^{2}$ In regard to rates affecting the development and protection of industry it would appear that the Board, until recently at any rate, has not taken as broad a view of its functions as the act contemplates or at least as the act would permit.

$\S 4$. In presenting the main principles that have governed the Canadian Board of Railway Commissioners in its jurisdiction over railway rates it is obvious that some minor aspects of the Board's activity in this direction have been ignored. The study, nevertheless, would be incomplete if these did not receive consideration. So much enters into the formation of the attitude and policy of the Board that without a complete survey of its position injustice to it and to the problems might be done. In concluding this chapter it is purposed to deal with certain of these minor aspects which may throw light upon the Board's treatment of rate cases. In general, the handling by the Board of the cases that have come before it has been judicial. While the Board "has never allowed any technicality to defeat the hearing of a complaint ... a simple statement of the case at issue should be supplied at the outset both to the Board and to the railway or express company against which the complaint is issued." So, in order "to deal with a complaint and decide it, the Board must hear the other side. If the other side has no informa-

1 See the Brampton Rate Case, 6/166. 2 Ante, p. 223. 
tion as to what it has to meet, then this plunging into the middle of things makes for delay, not for expedition. The Board desires to proceed with expedition; it cannot proceed by intuition." Combined with the judicial idea of hearing and decision the Board's power to act upon its own motion and to inform itself through its own officers gives it flexibility and possibilities of action that an ordinary court lacks. Even in this latter case every opportunity is customarily given to the parties concerned to make representations to the Board before judgment issues. ${ }^{1}$

A question of importance is its attitude to precedent. Although the Board has declared that it must "find the criteria of the reasonableness of Canadian rates within Canada," this does not mean that it has not availed itself of English and American experience. Of these sources of assistance it has made considerable use, though naturally not in a narrow and controlling way. Of the two, probably the most fruitful has been the American. English precedents, in the case of the Board, do not have the same binding weight of authority that they have in the ordinary Canadian law courts. American precedents, while they have little weight in the law courts, have commended themselves to the Commissioners by reason of the fact that the circumstances with which the Interstate Commerce Commission has to deal approximate somewhat closely Canadian conditions:-

While the provisions of the Canadian Railway Act differ in various respects from those of the Act to Regulate Commerce, and while the findings of the Commission organized under that act are by no means applicable in their entirety in Canada, it is manifest that when that body has dealt with problems identical with those coming before the Board, the findings and experiences of that Commission demand most careful attention. ${ }^{2}$

Hence the Canadian Board, being free to take or leave, has consulted more frequently the rulings of the American

$$
117 \text { C.R.C. } 113 . \quad 25 / 216 .
$$


body, where its decisions have been appropriate to $\mathrm{Ca}$ nadian cases under consideration. The debt in either instance has not been heavy. ${ }^{2}$ It has really been the practice of the Board only in enunciating a new principle or a modification of a principle to buttress its own conclusion by showing that the finding at which it has arrived is supported by similar conclusions found under similar conditions elsewhere. Thus, the Board's position that it is at the discretion of the carrier to meet or ignore competition is supported by both English and American holdings, ${ }^{2}$ as it is in the equally important ruling that joint tariffs need not be filed between lines competing for the same traffic when there is no inconvenience to the public. ${ }^{3}$ These are the two most important cases where English precedents have been cited.

Beyond these two judgments a more extensive correspondence is discovered with regard to American findings. The Canadian Board is at one with the Interstate Commerce Commission in holding that the presumption of reasonableness attaches to an established rate; that millingin-transit is a privilege; that tariffs may not be based on the use to which a commodity may be put; that costs of production are not to be equalized because of trade competition; that a line controlled by stock ownership must, in the determination of rates, be held part of one system; ${ }^{4}$ and that a rate between two points established in compliance with the provisions of statute law is the only legal rate between the points mentioned.

On the other hand, the Canadian body has taken wider

1 "This Board has always appreciated the value of the regulative work done by the Interstate Commerce Commission, and its findings have always been held in esteem. But the Board, in holding that the decisions of that commission are applicable in their entirety here only in cases where circumstances in Canada are on all fours with the circumstances upon which the aforesaid decisions depended, has recognized the burden placed upon it by parliament of investigating the special circumstances of the cases coming before it." $8 / 15$.
2 5/227-28.
$8 / 255$.
4 Cp. 9/139, 17 C.R.C. $324 ;$ 7/251. 


\section{RATE THEORIES AND PUBLIC POLICY}

ground in holding that an advance in a particular rate may be justified by proving a general increase in railway costs. ${ }^{1}$ The Interstate Commerce Commission has held that "such statements have little weight when presented in the abstract with no attempt to locate charges." This is, perhaps, the most marked divergence in position between the two bodies. The Board has profited by American experience in holding from the outset that competition between carriers is a dissimilar circumstance sufficient to justify lower rates to points where competition of this nature is present. The Board has failed to give effect to the contention that a railway company could not be forced to have traffic relations with other railways whose stability they did not recognize, ${ }^{2}$ holding merely that the interest of the public must be established.

The Board's attitude to the precedents created by itself is another phase of the problem. As the passing of time has added to the number of cases adjudicated, naturally the Board has had less and less occasion to turn to foreign judgments, finding sufficient guidance in its own holdings. Its decisions have been fairly consistent since its organization, although considerable changes have taken place in the personnel. The only marked exceptions appear in the International Pulpwood Rates Case, and the North Bay Interchange Traffic Case, already discussed. Greater weight appears to be given in recent years to the presumption of reasonableness attaching to an established rate than in the earlier days of the Board. The earlier attitude is revealed in the view that

while the previous existence of a rate affords evidence of its reasonableness, it is not conclusive evidence, but more or less cogent according to circumstance. ${ }^{3}$

Later cases indicate a tendency to give it considerable weight unless it can be very clearly shown that conditions
$18 / 271$.
2 VI J.O.R.R. 5. Cp. 11/189.
$4 / 223$. 
have changed. As regards the Board's general reliance upon its earlier decisions, before the war there appeared to be some danger that it was becoming rather formal and mechanical. In other words, the Board did not seem to be escaping altogether the vis inertia of tradition. Such a statement is made advisedly and rests upon a consideration of the general temper displayed in the whole group of rate decisions up to 1914. Some cases revealed a tendency to rely upon precedent rather than upon reason. The evil, for it is an evil, had not reached any measure of importance, but was to be just detected as a possible danger to the future usefulness of the Board. The great series of adjustments forced upon the railways by the war and by increased costs has, however, had its reflex upon the work of the Board. In facing a large series of difficult problems arising out of the national crisis, both in general in Canada and specifically in the transportation field, the Board has displayed a freshness, keenness, and vigor of treatment worthy of the times.

In the case of international rates, the Board has frequently pointed out that it has no control over transportation lines in the United States. ${ }^{1}$ Where injustice to a shipper is discovered to be due to the rates of carriage imposed on lines across the boundary, the Board has been unable to grant relief. In fact, however, the Board has exercised some influence upon international traffic, for if its power ceases at the boundary it at least has been able indirectly to touch foreign conditions by its control over the Canadian part of a joint rate. ${ }^{2}$ It is thus able to remedy to that degree any injustice in the charge. Moreover, it has provided that when an American line wishes it may file tariffs showing through rates to Canada with the Board and such rates become at once the legal rates between the points named. ${ }^{3}$ If the Canadian lines object to any rate quoted, they have to do so by applying to the Board for 1 7/189. Cp. VI J.O.R.R. $189 . \quad 27 / 237 . \quad 35 / 209$. 
the disallowance of the rate, rather than by filing an exception to it according to the practice of the Interstate Commerce Commission. Lines operating in Canada which quote rates to American terminals also come within the inhibitions of the long and short haul clause. Thus, in the International Rates Case rates to Windsor were held down by the rate to Detroit across the river. ${ }^{1}$

These cases show the limits of the Board's power of control over international rates. On the whole, its power is slight, and a larger degree of control of some sort is desirable from the standpoint of both the American and Canadian shipper, for

it is patent that the number of cases in which the through regulation of a rate involves dealing with the rate of both the American and Canadian carrier will steadily increase with the steadily increasing interrelation of the railway network of Canada and the United States. 2

This has been brought home to the Board on more than one occasion and is a natural result of the heavy interregional traffic between the two countries. The advantages to be gained are mutual, and the similarity in the principles that the regulative bodies of Canada and the United States have developed should make it a matter of no great difficulty to fix a method whereby cases of this nature could be passed upon. The Canadian Board at different times has suggested a means of accomplishing this end. ${ }^{3}$

In Davy vs. The Niagara, St. Catharine \& Toronto Railway Company and the Michigan Central Railway Company the Board expressed the opinion that the complainant was entitled to relief, but as part of the toll charged by the Michigan Central was for services rendered in the United States it was under the sole control of the Interstate Commerce Commission. ${ }^{4}$ The Board suggested the possibility of concurrent action:-
$13 / 8$.
$28 / 44$.
$311 / 115$.
$47 / 191$. 
The applicant has, I think, another course open to him. He may bring complaint before the Interstate Commerce Commission, and if that tribunal, upon investigation, is of opinion that an order should be made reducing the toll for the service in the State of New York, there is no reason that I know of why orders cannot be made by that and this Commission putting into effect the rate that the two Commissions regard as the proper one.

Another suggestion has been the establishment of a special tribunal to deal with these cases. In Stockton and Mallinson vs. The Dominion Express Company ${ }^{1}$ an application was made to secure joint rates on carloads of fruit and vegetables from the Western fruit-growing States to Regina. The application failed for lack of jurisdiction. The Board on this occasion said: -

Difficulties of this character regarding international traffic are continually arising; no tribunal now exists that can deal with them, and until such body is established, shippers and others must be left to work their disputes out with the carriers as best they can.

Until such a tribunal is established or arrangements for reciprocal action are concerted a large body of rates remain outside the scope of regulation and are a source of disturbance to the rate tribunals of both countries. The need of some action is manifest. ${ }^{2}$

Undoubtedly one aspect of the Board's method of handling rate problems has tended to increase the general confidence placed in the soundness of its decisions. In its opinions it has frankly indicated weak points in the submissions of the applicants or respondents before it. Where these

$18 / 276$.

2 "Contracts made in the United States for the carriage of carload traffic passing from one point to another in the United States are under the control of the Interstate Commerce Commission, and the Board having regard to international comity will not make an order as to demurrage charged for delay of such traffic in Canada, when no Canadian interest is involved, where the effect of such order would be to nullify a previous order of the Interstate Commerce Commission on the same subject matter." 17 C.R.C. 256. 
have concerned facts which were likely to be material factors in the decision, the parties have been given opportunity to enlarge their case and strengthen their presentation. The Board has not been illiberal in granting rehearings. Moreover, it has frequently used its own resources of investigation to probe matters of importance as deeply as the circumstances permitted. In this way important considerations have been developed that might otherwise have been missed. Consequently the final decision in important cases has rested upon as sure a foundation of fact as possible. In few cases has the Board fumbled in its conclusions of fact. This has made for the general stability of its decisions and in relatively few instances have they been overturned upon attack in the Supreme Court.

Nor can it be said that the Board has regarded its own orders as sacrosanct. This arises from the Board's view of its function as a regulative body, and from a recognition that changed conditions may make its orders repressive instead of corrective. It pointed this out when reversing a former decision on the rating of metallic shingles, in the following terms:-

The Board's function here is concerned with the prevention or correction of grievances. It is interested in the logic of the situation only when the creation or continuance of an illogical arrangement results in unjust discrimination against some portion of the public. It is patent that there is a burden of obligation upon the Board to attempt to redress such unjust discrimination where it had been created by the volition of a railway or railways. It needs no elaboration that the same burden rests on the Board, if as a consequence of the continuance of one of its orders, or the emergence of conditions not existent when such order was made, an unjust discrimination develops. ${ }^{1}$

In the White Pass \& Yukon Railway Case, the Pressed Brick Case, the Plymouth Cordage Company Case, the

$15 / 262$. 
Brampton Ticket Case, and other instances, the Board has shown readiness to suspend and rehear if more complete evidence was forthcoming, and in the event of doing so, if the fuller data adduced warranted, has reversed its former decision. The effect of this attitude has been to reduce appeals to the Supreme Court or Privy Council, to lead to the fullest possible ventilation of rate grievances before the Board, and to create popular confidence in its integrity. 


\section{CHAPTER IX}

\section{CONCLUSION}

$\S 1$. Some reflection upon the body of principles that the Board of Railway Commissioners has developed in the first twelve years of its history makes clear that its main characteristics grow out of the Canadian situation. The clue to the fundamental importance with which protection to investment is regarded is easily found in Canadian railway history - the repeated grants of assistance to lines not safely established, the continued recognition by the legislative organs of the Dominion that Canada's railway development is as yet unfinished, the necessity of avoiding a financial débâcle, - all these factors are a background to the Board. It is therefore quite natural that they should influence its holdings. In one respect, too, the Board has been dealing with a highly dynamic situation. While the railway traffic of Canada is divided practically between three great systems, yet the Canadian Pacific is the only system to have arrived at mature strength and development. The other two are straining their resources, with the formal approval of Parliament, to realize ambitious schemes. Not until the Grand Trunk Pacific and Canadian Northern have completed their transcontinental lines and normalized their expenditures and revenues can the full competitive and Eastern-vs.-Western rates problems be accurately appraised and receive a final disposition. Indeed, since the outbreak of the war in 1914, the weaker roads have become so enmeshed in difficulties that it is almost certain a radical Parliamentary solution of the whole problem will have to be sought.

When the time becomes ripe for a permanent settlement, 
the question of what is the capital upon which fair return is to be paid will have to be probed into and discussed more fully than it has been in the past. The collateral problems of capital and income which will indirectly arise will require to be determined. The larger and overshadowing problem of whether rates shall be sanctioned and upheld which would have been quite unnecessary under a less grandiose scheme of transcontinental railroad service for Canada must be faced. When that time comes it will be discovered that the body of principles the Board has developed does not afford a sufficiently wide basis to permit of a satisfactory and wise solution of the question even if recourse is ultimately had to some form of legislative relief. No criticism of the Board is to be implied here, but the point desired to be emphasized is briefly this: international rivalry and competition led Canada to build a costly but not fully utilized system of canals; the same forces have compelled the construction of equally costly systems of railways. When the three transcontinentals are completed it now seems likely that the traffic available for the long interregional haul will not be sufficient to enable all of the facilities to be profitably utilized, particularly if the Hudson's Bay Railway offer an alternative route. Now, under these conditions can the Board of Railway Commissioners, or Parliament, in support of the principle that fair return on investment is the basis of reasonable rates, clamp down high rates on those parts of the railway systems where the traffic will bear it? Can Parliament or the Board in fact, by lending sanction to the railways for such a procedure, be certain that the end desired shall be gained? The point to be driven home is that elements inhere in the rate situation of Canada that go too deeply for anybody to solve, in the ordinary course of events, on abstract principles. The ultimate solution will probably rest on compromise and may be found by Parliament itself. It may issue in a large element of Govern- 
ment ownership, or a new concentration of railway ownership with one of the transcontinental lines eliminated.

\$2. Recognition must be given to the fact that the peculiar features of the Canadian situation have worked against a large and effective control by the Board of rates savoring of discrimination. This is to be accounted for chiefly by the prevalence of competition by rival rail and water carriers. The Board has put itself on record that the great bulk of the traffic of Eastern Canada moves on compelled rates. If there be added to this the holdings, even though they be unimpeachable in themselves, that branch lines, volume of traffic, joint rates, all justify differential treatment, and that the Board has no power to order a developmental rate except where one already in force may be extended, or to equalize competitive rates, it will be apparent that the power of the Board to control 'rates in this respect is confined to rather narrow limits. At most, it may remedy grosser cases of discrimination or excessive charge.

It was shown that for secondary criteria of reasonable rates the Board has relied largely upon cost factors. The only criticism to be offered here is that some of the presumptions made appear to have been accepted without careful enough examination. The relative costs of moving branch-line traffic as compared with main-line traffic is a case in point. Where branch mileage forms such a large proportion of the whole mileage of the Dominion the principle is one of importance and should rest on solid ground. The comparatively small use made of the value of the commodity principle of rate-making has been accounted for by the nature of the cases brought before the Board rather than by any refusal to admit its validity. Probably in the future this principle will receive more extensive application.

The position of the Board in regard to industrial development from the first has been that it is not concerned 
where industrial centers develop or what form of industrial organization appears. It has considered that its duty lies in the narrower field of insuring justice to shippers regardless of social effects. The only modification to this general position is to be traced in cases where industry has grown up under certain rate conditions the withdrawal of which would destroy it. In cases of this nature the Board has recognized, within limits, an obligation to see that the industry is not injured. The general effect of the principles of rate-making, however, has clearly been to promote the concentration of industry in the large centers where geographical and artificial conditions combined have been given full weight by the Board. This naturally follows also from the freedom that the railways possess in respect to encouraging the development of industrial Canada, through their absolute discretionary control over the initial installation of developmental rates.

Fundamentally, the Board's position is based on the essentially English economic doctrine that social welfare will be best attained by giving the greatest freedom to the principle of self-interest. There is complete absence in the decisions of the Board of the modern neo-mercantilistic tendency to manipulate rates for social ends. This national indifferentism is more remarkable in view of the strong current of national feeling that has been the moving force behind the railway development of Canada. It is probable, however, that as a clearer apprehension of the influence of railroad rates upon national development is gained by the Canadian public, the Board will not escape the modern drift of tendency.

These reflections all point to the conclusion that the Board of Railway Commissioners of Canada has not profoundly modified Canadian industrial development through its control over rates. This is, indeed, true. Indirectly its influence has been most salutary. The careful scrutiny given to new tariffs, the opportunity afforded in- 
terests affected of being heard, have undoubtedly meant a more equitable and harmonious rate structure. But on the whole, while the Board has caused the reduction of excessive rates, and has eliminated certain abuses of discrimination, it has not used its power over rates and tariff to influence the ordinary commercial development of the Dominion. It has essentially functioned as a convenient informal court of justice rather than as a regulative commission. 

No. 1

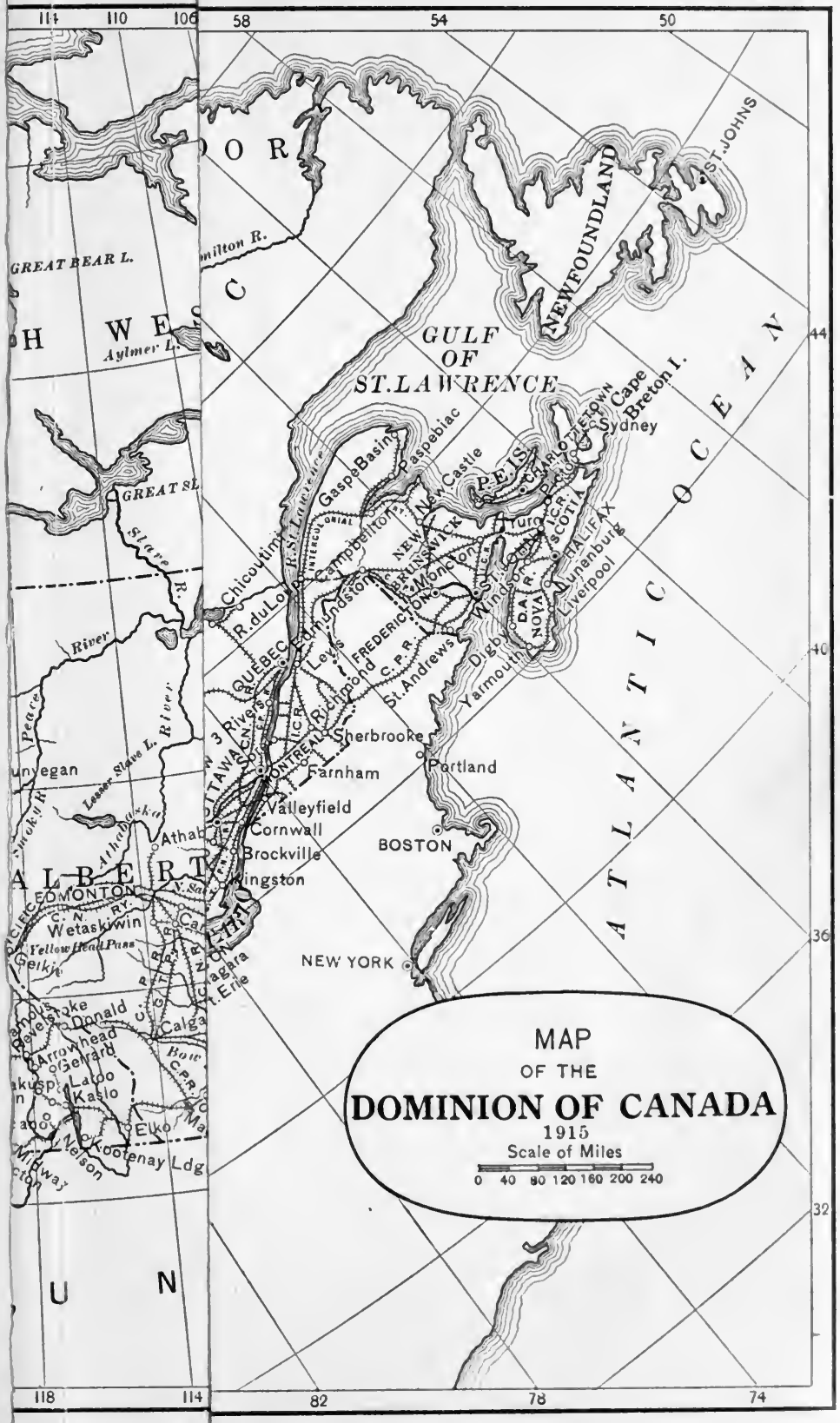





\section{BIBLIOGRAPHICAL NOTE}





\section{BIBLIOGRAPHICAL NOTE}

Material for a general study of Canadian transportation development falls roughly into three groups: first, official records, consisting of statutes, annual departmental reports, special reports, Hansard Debates, and company reports; secondly, general works, biographies and other writings of statesmen, engineers, and financiers intimately connected with Canadian transportation development; thirdly, miscellaneous contemporaneous articles, notes, pamphlets, and studies. In the narrower field of legal regulation and control excellent works and records are available in law reports, the Annual Reports of the Board of Railway Commissioners for Canada, MacMurchy \& Dennison's (or Spence's) Canadian Railvoay Cases, and the series of Judgments, Orders, Regulations, and Rulings of the Board of Railway Commissioners for Canada. Three general treatises are worthy of notice, MacMurchy \& Dennison's Railway Law of Canada; Jacobs's The Railway Law of Canada; and Lefroy's Canada's Federal System. Secondary studies of importance are Trout's The Railways of Canada, McLean's "National Highways Overland," in Canada and Its Provinces, vol. x; Skelton's The Railway Builders in the Chronicles of Canada Series, and Myers's History of Canadian Wealth, vol. $r$.

The present list of references is not exhaustive. The writer has found these works and documents of assistance in the preparation of his study.

\section{I \\ Official Records}

1. Annual Reports of Companies, Canadian Northern Railway System, Canadian Pacific Railway Company, Grand Trunk Railway Company, etc.

2. Annual Reports of the Department of Railway and Canals. Ottawa.

3. Canada Year Book (yearly). Ottawa. (Statistical Abstract and Record of Canada, 1886-8; The Statistical Year Book of Canada, 1889-1904; present title since.) 
4. Canal Statistics (yearly). Department of Railways and Canals. Ottawa.

5. Cayley, W., Statements, Reports, and Accounts of the Grand Trunk Company of Canada. Laid before the Legislative Assembly, 1857.

6. Durham, Earl of, Report of the Affairs of British North America. London, 1839.

7. Financial Statements of the Canadian Northern Railway System, April 15th, 1916. Ottawa, 1916.

8. Financial Statements Respecting the Grand Trunk Pacific Railway Company. Ottawa, 1916.

9. Fisher, Hon. Sydney, Canada, its History, Production and Natural Resources. Ottawa, 1905.

10. Hansard Debates of the House of Commons. Ottawa.

11. Interim Report: Statistical Examination of Certain General Conditions of Transportation Bearing on the Economic Problem of the Proposed Georgian Bay Canal, by W. Sanford Evans, Chairman, Georgian Bay Canal Commission. Ottawa, 1916.

12. Railway Statistics of the Dominion of Canada (yearly). Department of Railways and Canals. Ottawa.

13. Reports of the Board of Railway Commissioners for Canada. Ottawa.

14. Report of the Commissioners Appointed to Enquire into the Affairs of the Grand Trunk Railway. Quebec, 1861.

15. Reports upon Railway Commissions, Railway Rate Grievances and Regulative Legislation by Professor S. J. McLean, M.A., Ph.D. Ottawa, 1902.

16. Report of the Railway Rates Commission; Sessional Papers, No. 39, vol. II, 1895.

17. Report of the Royal Commission to inquire into Railways and Transportation in Canada. Ottawa, 1917.

18. Report of the Royal Commission on Railways, Hon. A. T. Galt, Chairman. Ottawa, 1888.

19. Robinson, Major, Final Report of the Officers employed on the Survey of the Line for the Quebec and Halifax Railway with the' Subsequent Correspondence thereon on Public Works in Canada. London, 1849.

20. Statutes and Proclamations, Federal and Provincial, of the Dominion of Canada. 
II

General Works

1. Buckingham and Ross, Life and Times of Hon. Alexander Mackenzie. Toronto, 1892.

2. Canadian Annual Review: Edited by C. Hopkins. Toronto.

3. Cartwright, Rt. Hon. Sir Richard, Reminiscences. Toronto, 1912.

4. Fleming, C.E., Sanford, The Intercolonial Railway. Montreal, 1876.

5. Galt, Hon. A. T., Canada, 1849 to 1859. Quebec, 1860.

6. Hincks, M.P., Hon. Francis, Canada, Its Financial Position and Resources. London, 1849.

7. Hincks, Sir Francis, Reminiscences of My Public Life. Montreal, 1884.

8. Howe, Hon. Joseph, Speeches and Public Letters. Boston, 1858.

9. Keefer, C.E., T. C., Eighty Years' Progress of British North America. Toronto, 1863.

10. Keefer, C.E., T. C., "Montreal" and "The Ottawa": Two lectures delivered before the Mechanics Institute of Montreal. Montreal, 1854.

11. Keefer, C. E., T.C., Philosophie des Chemins de Fer. 4th Edition. Montreal, 1853.

12. Kingsford, C.E., William, The Canadian Canals, Their History and Cost, with an Enquiry into the Policy necessary to advance the Well-Being of the Province. Toronto, 1865.

13. McLean, Ph.D., S. J., National Highways Overland, vol. x, Canada and its Provinces. Toronto, 1915.

14. Merritt, William Hamilton, Brief Review of the Origin, Progress, Present State, and Future Prosperity of the Welland Canal. St. Catharines, 1852.

15. Morgan, H. J., Dominion Register and Review. Montreal.

16. Myers, Gustavus, History of Canadian Wealth, vol. I. Chicago, 1914.

17. Preston, W. T. R., Life and Times of Lord Strathcona. Toronto, 1915.

18. Pope, Hon. Joseph, Memoir of the Rt. Hon. Sir John A. MacDonald. London, 1895.

19. Simcoe, Mrs. John Graves, Diary of, with notes by J. Ross Robertson. Toronto, 1911. 
20. Skelton, Ph.D., O. D., The Railway Builders; A Chronicle of Overland Highways. Toronto, 1916.

21. Trout, J. M., \& Edward, The Railways of Canada, etc. Toronto, 1871.

22. Tupper, Bt., Rt. Hon. Sir Charles, Recollections of Sixty Years in Canada. London, 1914.

23. Watkins, Bt., Sir E. W., Recollections by, Canada and the United States. London, 1887.

24. Willson, Beckles, The Life of Lord Strathcona and Mount Royal. Boston, 1915.

25. Holland, Bernard, The Fall of Protection. London, 1913.

\section{III}

\section{Pamphlets, Articlies, Notes}

1. Allan, H., The "Times" and its Correspondents on Canadian Railways. London, 1875.

2. Backwoodsman, By a, Statistical Sketches of Upper Canada. 3rd Edition. London, 1833.

3. Bliss, Henry, Statistics of the Trade, Industry and Resources of Canada and other Plantations in British America. London, 1833.

4. Bonnycastle, Sir Richard H., The Canadas in 1841. London: Henry Colburn, 1841.

Canada and the Canadians. London, 1846.

5. Brown, J. Gordon, Essay on the Advantages of the Canals to the Farmers of Canada. Toronto, 1850.

6. Brown, Thomas Storrow, History of the Grand Trunk Railway of Canada, compiled from public documents. Quebec, 1864.

7. Buchanan, James, Letter to His Excellency, Sir Francis Bond Head, as to Railroads in Upper Canada and the Means of Constructing Them Without the Aid of Foreign Capital. Toronto, 1836.

8. Canadiana. Montreal, 1890.

9. Coffin, Wm. F., The Canal and The Rail. Montreal, 1848.

10. Croil, James, Steam Navigation and its Relation to the Commerce of Canada and the United States. Toronto, 1898.

11. Duncan, James, The Canadas as They Now Are, by a Late Resident. London, 1833.

12. Fowler, Thomas, The Journal of a Tour Through British America to the Falls of Niagara. Aberdeen, 1832. 
13. Godley, John Robert, Letters from America. London, 1844.

14. Hogan, J. Sheridan, Canada. Montreal, 1855.

15. Jenkins, M.P., Edward, The Times and Mr. Potter on Canadian Railways: A Criticism of Critics. London, 1875.

16. Martin, R. Montgomery, History of Canada. London, 1836.

17. Preston, T. R., Three Years' Residence in Canada from 1837 to 1839 . London, 1840.

18. Proceedings of a Committee appointed at Brockville, the Tenth of November, 1830, on the Improvement of the St. Lawrence, with Reports, etc. Brockville, 1831.

19. Projector, By a, A Concise View of the Inland Navigation of the Canadian Provinces, etc. St. Catharines, 1832.

20. Smith, Robert Carmichael, Letter to Earl Grey. London, 1850.

21. Synge, Capt. Millington, Great Britain One Empire, On the Union of the Dominions of Great Britain by Intercommunion with the East via British North America. London, 1852.

22. Todd, Henry Cook, Notes on Canada and the United States of America. Toronto, 1855.

23. Tour Through Upper and Lower Canada, A, by a Citizen of the United States. Litchfield, 1799.

24. Weld, Isaac, Voyage au Canada, pendant les annees 1795, 1796 et 1797. Paris [N.D.].

\section{IV}

\section{Rathway Law Books, Digests, Judgments}

1. Annual Reports of the Board of Railway Commissioners for Canada, Ottawa. (Contains in Appendix report of principal judgments delivered during the year.)

2. Digest of Ontario Case Law, together with cases in the Supreme and Exchequer Courts of Canada and Canadian Cases in the Judicial Committee of the Privy Council; compiled by order of the Law Society of Upper Canada. Toronto, 1903.

3. Congdon, F. T., Congdon's Nova Scotia Digest. Toronto.

4. Jacobs, K.C., S. W., The Railway Law of Canada. Montreal, 1909.

5. Judgments, Orders, Regulations, and Rulings of the Board of Railway Commissioners for Canada. Ottawa. (J.O.R.R.)

6. Lefroy, A. H. F., Canada's Federal System. Toronto, 1913.

7. MacMurchy \& Dennison, Railroad Law of Canada. 2nd Edition. Toronto, 1911. 
8. MacMurchy \& Dennison, or MacMurchy \& Spence, Canadian Railway Cases. Toronto. (C.R.C.)

9. Robertson, K.C., Andrew, A Digest of all the Reports Published in Lower Canada to 1863. Montreal.

10. Stephens, B.C.L., C. H., Quebec Law Digest from 1810 to 1877. Montreal.

11. Stevens, J. G., Stevens' Digest 1825 to 1879 . Toronto.

\section{$\mathbf{V}$}

\section{Magazines}

1. Canadian Railway and Marine World. Toronto.

2. Railway Age Gazette. Chicago. 
LIST OF CASES CITED 



\section{LIST OF CASES CITED}

Algoma Central and Hudson Bay Ry. Co. vs. Grand Trunk Ry. Co., 4/254; 8 C.R.C. 46..................... 219, 228

Almonte Knitting Co. vs. The Canadian Pacific and Michigan Central Ry. Co., 1/71; 3 C.R.C. 441 ................ 163

American Coal \& Coke Co. vs. Michigan Central Ry. Co., 11/115;

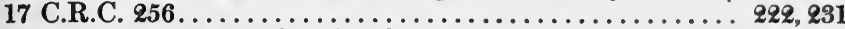

Anchor Elevator \& Warehousing Co. et al. vs. Canadian Pacific Ry. Co., 4/259; 9 C.R.C. 175 ....................... 193

Application for through rate of freight from Midland, Ontario, to Cleveland, Ohio, VI J.O.R.R. 491............... 153, 180

Atikokan Iron Co., Ltd., Complaint re Switching charges, 7/257; 12 C.R.C. 6............................. 193 Attorney-General vs. The Ontario, Simcoe and Huron Ry., 6 G.C.R.

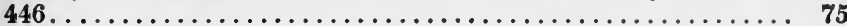

Auger \& Son and D'Auteuil Lumber Co., Complaint re Change in rates on Pulpwood, 11/165; 19 C.R.C. $401 \ldots \ldots \ldots \ldots \ldots \ldots 131$ Aylmer Condensed Milk Co. vs. American Express Co., 17 C.R.C. 100 .

Battle Creek Toasted Corn Flakes Co. re C.L. Minimum on Toasted Corn Flakes, 6/312; 12 C.R.C. $11 \ldots \ldots \ldots \ldots \ldots \ldots \ldots \ldots$. 188

Berliner Gramophone Co. v8. Canadian Freight Association, 8/37;

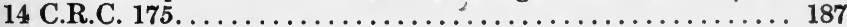

W. S. Bilton, Complaint against excessive freight charges on coal,

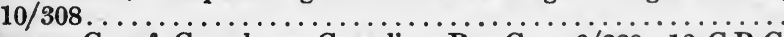

Blaugas Co. of Canada vs. Canadian Ry. Cos., 6/339; 12 C.R.C. $303 . \ldots \ldots \ldots \ldots \ldots \ldots \ldots \ldots \ldots \ldots \ldots \ldots \ldots \ldots \ldots \ldots \ldots$ 196. 202

Blind River Board of Trade, Complaint $r e$ rates on bar iron, $9 / 261$; 15 C.R.C. $147 \ldots \ldots \ldots \ldots \ldots \ldots \ldots \ldots \ldots \ldots$ 142, 144, 218 Bowlby, C. A. et al. vs. Halifax and South Western Ry. Co., VI J.O.R.R. 367. ....................... 145, 151, 156

Brampton Commutation rates Case, $4 / 245 ; 8$ C.R.C. $42 \ldots \ldots . .206$ Brampton Commutation rates Case, 6/166; 11 C.R.C. $370 \ldots 206,225$ British American Oil Co. vs. Grand Trunk Ry. Co. (Stoy Case), 5/211; 9 C.R.C. 178..................... 172, 215, 230

British Canadian Canners vs. Grand Trank Ry., 14 C.R.C. 346 ... 193

British Columbia News Co. re express rates on Magazines, 7/35; 13 C.R.C. 176 . . . . . . . . ...................... 209

British Columbia Sugar Refining Co. vs. Père Marquette Rd. Co., 5/879; 10 C.R.C. $169 \ldots \ldots \ldots \ldots \ldots \ldots \ldots \ldots \ldots \ldots \ldots \ldots \ldots$ 138, 157

Brown vs. Quebec \& Lake St. John Ry. Co., 18 C.R.C. 342 . . . . . 122

Cadwell Sand and Gravel Co., Complaint re rate on pressed bricks from Bradford, Penn., to Windsor, Ont., 8/44; 14 C.R.C. 172 
Canadian Canners Limited vs. Canadian Pacific Ry. Co., 3/126 ... 174

Canadian China Clay Co. vs. Canadian Northern Ry. Co. et al., $10 / 326 \ldots \ldots \ldots \ldots \ldots \ldots \ldots \ldots \ldots \ldots \ldots \ldots 158,162,169$

Canadian Freight Association vs. Cadwell Sand and Gravel Co., 9/271; 15 C.R.C. 156......................... 185

Canadian Freight Association vs. Fruit Growers Association of Ontario, $5 / 245$.

Canadian Freight Association and Industrial Corporation, 1/69; 3 C.R.C. 427.

Canadian Lumbermen's Association vs. Grand Trunk and Canadian Pacific Ry. Cos., 6/138; 10 C.R.C. 306 . . . . . . . . . . . 124, 132

Canadian Lumbermen's Association and Montreal Board of Trade vs. Grand Trunk Ry. Co. et al., 17 C.R.C. 102.

Canadian Manufacturers' Association, Complaint $r e$ classification of Metallic shingles, $1 / 71 ; 4 / 148$

Canadian Manufacturers' Association vs. Grand Trunk and Cana. dian Pacific Ry. Cos. re rates on brick, gravel, etc., 11/154 ..... 184

Canadian Northern Express and Central Ontario Ry. Co. re increase in rates, $8 / 278 ; 14$ C.R.C. 183

Canadian Northern Ontario Ry. Co. vs. Grand Trunk and Canadian Pacific Ry. Cos. (Muskoka rates case Nos. 1 and 2), 5/254;

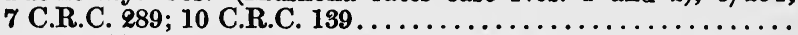

Canadian Northern Railway $r e$ Special freight tariff C.R.C. No. E-132, 11/274 ............................ 205, 208 Canadian Oil Cos. Limited, application for a rate of 56 cents per 100 pounds from Petrolia, Ont. to Winnipeg, Man., on petroleum and its products, $7 / 206 ; 12$ C.R.C. 351 ...... 141, 188, 202, 203, 216 Canadian Oil Cos. Limited vs. the Grand Trunk and Pacific Ry. Cos., 7/194............................ 160, 171

Canadian Piano \& Organ Manufacturers' Association, application for the classification of Musical Instruments, 6/317 . ........ 190

Canadian Portland Cement Co., application for a reduced through rate on bituminous coal from Black Rock, N.Y. to Marlbank, Ontario, 5/231; 9 C.R.C. $209 \ldots \ldots \ldots \ldots \ldots \ldots \ldots \ldots$ 126, 151, 202

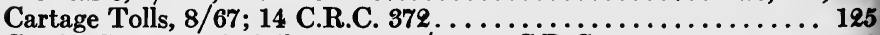

Cartier Stop-over Privilege case, 4/256; 9 C.R.C. $227 . \ldots \ldots \ldots \ldots 193$

City of Toronto and Town of Brampton vs. Grand Trunk and Canadian Pacific Ry. Cos. (Brampton Commutation rates case No. 2),

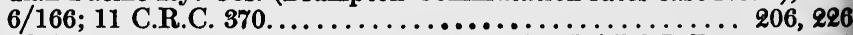

Coal, increase in rate on, from Niagara frontier, VI J.O.R.R. 329. . 169

Coal, transportation traffic practices, VI J.O.R.R. 438.......... 223

Commodity rates to Pacific Coast Terminals and Intermediate Points, 32 I.C.C.R. 611....................... 152

Commodity Rates to Pacific Coast Terminals and Intermediate Points, 40 I.C.C.R. 35........................ 152

Commutation Tickets, between St. Hyacinthe and Montreal, 9/295. 207

Consumers' Gas Co. Complaint re rates on gas house coke, 8/265 . 160

Continental Oil Co. Ltd. et al., for a reduction in the rate on oil products and oil, $7 / 212 ; 13$ C.R.C. $156 \ldots \ldots \ldots \ldots \ldots \ldots \ldots$ Cowichan Creamery Association, Complaint $r e$ rates on Alfalfa Meal, 11/108; 18 C.R.C. 39........................... 196 Cream rates on express shipments, $7 / 268 ; 8 / 11 ; 14$ C.R.C. 142 ;

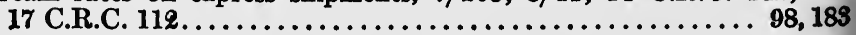


Crowsnest Pass Co. vs. Canadian Pacific Ry., 4/252; 8 C.R.C. 33. . 161 Cut Glassware Importers vs. Canadian Freight Association, 12

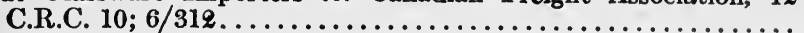

Davy vs. Niagara, St. Catharines \& Toronto Ry. Co. and the Michigan Central Ry. Co., 7/189; 9 C.R.C. 493; 12 C.R.C. 61 $124,133,230,231$

Dawson Board of Trade vs. White Pass and Yukon Ry. Co., 5/219; 6/346; 7/216; 9 C.R.C. $190 ; 11$ C.R.C. 402; 13 C.R.C. 527 102, 103, 106

Dominion Millers' Association, Complaint re rates on flour to Mari-

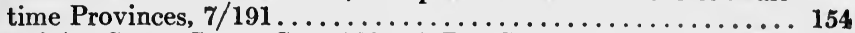

Dominion Sugar Co. vs. Grand Trunk Ry. Co. et al., 17 C.R.C. 231.151

Dominion Sugar Co. vs. Grand Trunk Ry. Co. et al., 17 C.R.C.

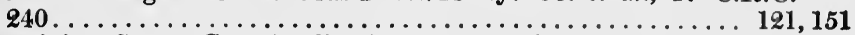

Dominion Sugar Co., Application for re-adjustment of rates on sugar in carlots from Wallaceburg, Ont., to Winnipeg and other Manitoba points, etc., $7 / 243 \ldots \ldots \ldots \ldots \ldots \ldots \ldots \ldots \ldots \ldots$

Dominion Transportation Co. vs. Algoma Central \& Hudson Bay Ry. Co., 17 C.R.C. $422 \ldots \ldots \ldots \ldots \ldots \ldots \ldots \ldots \ldots \ldots \ldots . \ldots \ldots$

Doolittle \& Wilcox vs. Grand Trunk and Canadian Pacific Ry. Co. (Stone Quarry Rates Case), 4/244; 8 C.R.C. 10.......... 126 Doucet ; Frères vs. Canadian Pacific Ry. Co., VI J.O.R.R. 286 . . 158, 180

Eastern Rates Case, VI J.O.R.R. 133, 189, 201, 203, 241 $86,93,116,140,147,214,224,230$

Edmonton, Clover Bar Sand Co. vs. Grand Trunk Pacific Ry. Co., 17 C.R.C. 95 . . . . . . . . . . . . . . . . . . . . 158, 209

Edmonton, Dunvegan and British Columbia Ry. Co., 10/340; 19 C.R.C. $395 \ldots \ldots \ldots \ldots \ldots \ldots \ldots \ldots \ldots \ldots \ldots \ldots \ldots \ldots \ldots$ 122, 167

Elder Dempster \& Co. vs. Canadian Pacific and Grand Trunk Ry. Cos., 5/281; 10 C.R.C. $334 \ldots \ldots \ldots \ldots \ldots \ldots \ldots \ldots \ldots$. 62,217

Essex Terminal Ry., re removal as a participating carrier in tariffs and supplements applicable to international traffic, $10 / 138 \ldots \ldots 192$

Eureka Co. and Brick Co. vs. The Canadian Pacific Ry. Co.,

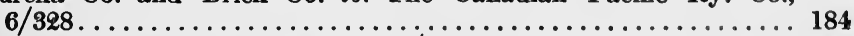

Express Companies Investigation, $6 / 240 \ldots \ldots \ldots \ldots \ldots \ldots \ldots \ldots \ldots \ldots \ldots \ldots, 175,196$

Express Investigation, 9/309...................... 119

Farmers' Dairy and Produce Co. vs. Canadian Pacific Ry. Co.,

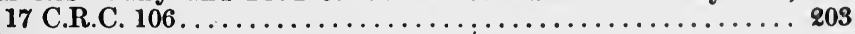

Flannelette Sheets, $r e$ classification of, $9 / 871 \ldots \ldots \ldots \ldots \ldots \ldots$

Fonthill Gravel Company, Limited, Application for reduction in rates on gravel, $10 / 120 ; 17$ C.R.C. $248 \ldots \ldots \ldots \ldots \ldots \ldots \ldots$

Fredericton, N.B., Board of Trade, Complaint re Discrimination,

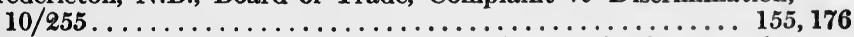

Fruit Growers' Association of Ontario, Application for Stoppage-intransit privilege, $8 / 275 ; 14$ C.R.C. $370 \ldots \ldots \ldots \ldots \ldots \ldots \ldots . \ldots 193$

Fullarton Lumber \& Shingle Co. vs. Canadian Pacific Ry. Co., 9/308; 17 C.R.C. 79.......................... 184

Galbraith Coal Co. vs. Canadian Pacific Ry. Co., 6/149; 10 C.R.C.

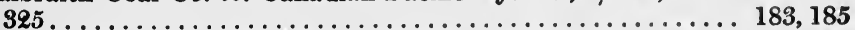

Gas House Coke Rates Case, 6/367; i2 C.R.C. $289 ; 8 / 265 \ldots \ldots \ldots 160$ 
Goose Lake District, Saskatchewan, Unmarketed and unstored grain and transportation thereof, VI J.O.R.R. 1, 3, 294, 312........ 223

Graham Co. Limited, Complaint against the freight rates on desiccated vegetables, VI J.O.R.R. $267 \ldots \ldots \ldots \ldots \ldots \ldots$ 158, 163, 202

Grand Trunk Ry. Co., Application for permission to make reduced rates on Coal used for manufacturing purposes, 1/70; 3 C.R.C. 438204

Grand Trunk Ry. Co. vs. Canadian Northern Ry. Co. re Union Station, Toronto, $11 / 189 \ldots \ldots \ldots \ldots \ldots \ldots \ldots \ldots \ldots . \ldots . \ldots 29$

Grand Trunk Railway vs. City of Toronto, 1 C.R.C. 92; 32 O.R. 12088

Gravel, $r e$ rates on, $11 / 145 \ldots \ldots \ldots \ldots \ldots \ldots \ldots \ldots \ldots \ldots . \ldots \ldots$

Great Northern Ry. Co. vs. Canadian Northern Ry. Co. (Ft. William Coal case), 6/361; 11 C.R.C. $424 \ldots \ldots \ldots \ldots \ldots \ldots \ldots .218$

W. J. Guest Fish Co., Complaint of $r e$ express rates on fresh fish in carloads from Vancouver to Winnipeg, 10/197; 18 C.R.C. 1

$155,172,206$

Hay \& Co., Limited, and J. H. Still Manuf acturing Co., Limited, re Minimum loading requirements for logs, VI J.O.R.R. 474 . . 159, 211 Hagersville Crushed Stone Co. vs. Michigan Central Ry. Co., VI J.O.R.R. 419. . . . . . . . . . . . . . . . . . . . . . . 164

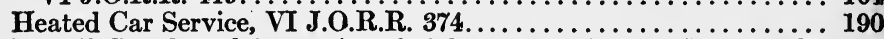

Howell Co., Complaint against freight rates on Import Wood Pulp, 9/297; 17 C.R.C. 97......................... 182

Hudson Bay Milling Co., $r e$ differences in freight charges between G.N.R. Co. and C.P.R. Co., Talmo, B.C., 9/274; 16 C.R.C. 254

Hull Electric Ry. Co., Application for approval of standard passenger rate of $2 \frac{1}{2}$ cents a mile, $10 / 339 \ldots \ldots \ldots \ldots \ldots \ldots \ldots \ldots . \ldots 1$

Icing Charges, VI J.O.R.R. 81...................... 190

Imperial Oil Co., Limited, Application for an order directing reduction in freight, on petroleum and petroleum products in carloads from Vancouver east to Alberta points, $10 / 124 \ldots \ldots \ldots \ldots \ldots .202$

Imperial Rice Milling Co., Application for reduction in rates on rice, etc., 8/270; 14 C.R.C. $375 \ldots \ldots \ldots \ldots \ldots \ldots \ldots \ldots \ldots \ldots . \ldots 157$

Imperial Steel and Wire Company, Limited, vs. Grand Trunk Ry. Co., 6/359..................................... 228

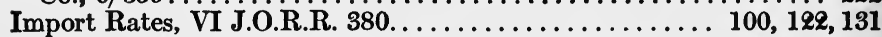

Increase in Freight Rates on Canned Goods and Hardware to points on the Pacific Coast, Complaint against, VI J.O.R.R. 501 . . . . 152

International and Toronto Board of Trade, rate cases, $3 / 5 \ldots$ 172, 231

International Paper Co. et al. vs. Grand Trunk Ry. Co. et al. (International Pulpwood Rates Case), 8/271; 15 C.R.C. 110

$127,182,224,229$

Interswitching, 4/214; 7 C.R.C. $302 \ldots \ldots \ldots \ldots \ldots \ldots \ldots \ldots \ldots 190$

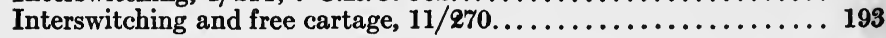

Joint Freight and Passenger Tariffs against the sum of the locals, 5/216; 10 C.R.C. $343 . \ldots \ldots \ldots \ldots \ldots \ldots \ldots 100,173,174,175,227$ Joint rates and concurrence notices, 11/253; 19 C.R.C. $379 \ldots \ldots .222$ Joint tariffs, VI J.0.R.R. 406 . . . . . . . . . . . . . . . . 228

Kemp Manufacturing Co. and Winnipeg Ceiling \& Roofing Co., Complaint $r e$ Metallic Shingles, 5/262; 10 C.R.C. 161 ..... 198, 233 
Laing-Harris Coal and Grain Company v8. Atchison, Topeka and Santa Fé Ry., 12 I.C.C. Rep. 556.................. 191

Lake Superior Paper Co., Ltd., vs. Algoma Central \& Hudson Bay Ry. Co., VI J.O.R.R. 391..................... 131, 161

Lamontagne Limited, Application $r e$ mixed carloads, $7 / 186 ; 12$

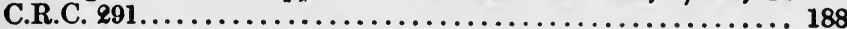

H. E. Ledoux Co., Limited, Application for C.L. Rating on Cigars, 7/185; 12 C.R.C. 3....................... 187, 197

London \& Lake Erie Ry. Co. vs. the Michigan Central Ry. Co. and the London \& Pt. Stanley Ry. Co., VI J.O.R.R. 89.......... 222

London Interswitching Case, $1 / 86 \ldots \ldots \ldots \ldots \ldots \ldots \ldots \ldots \ldots . . .190$

Malkin \& Sons vs. Grand Trunk Ry. Co. (The Tanbark Case), 4/268; 8 C.R.C. $183 \ldots \ldots \ldots \ldots \ldots \ldots \ldots \ldots \ldots \ldots \ldots$ 164, 165

Manitoba Free Press et al., Complaint relative to express classification of newspapers, $5 / 269 ; 7 / 286 \ldots \ldots \ldots \ldots \ldots \ldots \ldots .99,193$

Massiah vs. Canadian Pacific Ry. Co., 17 C.R.C. $88 \ldots \ldots \ldots \ldots \ldots . . \ldots 207$

Michigan Sugar Co. vs. Chatham, Wallaceburg \& Lake Erie Ry. Co., 6/205; 11 C.R.C. $353 \ldots \ldots \ldots \ldots \ldots \ldots \ldots \ldots \ldots \ldots$.............. 224

Thomas Miles Sons, Complaint re rates on gas house coke, 6/367;

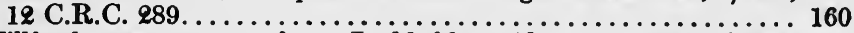

Millfeeds, $r e$ rates on from Lethbridge, Alta., to Sweet Grass,

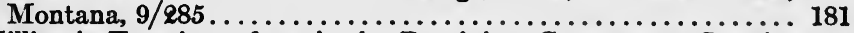

Milling-in-Transit and grain in Dominion Government Interior Elevators, $11 / 171 \ldots \ldots \ldots \ldots \ldots \ldots \ldots \ldots \ldots \ldots \ldots . \ldots \ldots$

Milling-in-Transit rates, St. Thomas, Ont., 9/287; 16 C.R.C. 425 ... 219

Montreal Board of Trade Application re rates on corn and cornmeal, 7/253; 14 C.R.C. $351 \ldots \ldots \ldots \ldots \ldots \ldots \ldots \ldots \ldots \ldots \ldots \ldots$

Montreal Board of Trade Application for milling-in-transit privilege for corn, file 12384 , cited $8 / 276 \ldots \ldots \ldots \ldots \ldots \ldots \ldots \ldots . \ldots . \ldots . \ldots$

Montreal Board of Trade vs. Canadian Pacific Ry. Co. et al., is C.R.C. $6 \ldots \ldots \ldots \ldots \ldots \ldots \ldots \ldots \ldots \ldots \ldots \ldots \ldots \ldots \ldots \ldots$.

Montreal Board of Trade, Complaint against proposed increase in rates on hay shipped to points in Eastern United States, 7/238 .. 125

Montreal Board of Trade vs. Grand Trunk and Canadian Pacific Ry. Cos., $r e$ grain rates, $6 / 146 \ldots \ldots \ldots \ldots \ldots \ldots \ldots \ldots \ldots . \ldots \ldots$

Montreal Produce Merchants' Association, Complaint against advance in winter export rates on butter and cheese, $3 / 149 ; 4 / 222$

$99,209,215,229$

Montreal Produce Merchants' Association vs. Grand Trunk Ry. and Canadian Pacific Ry. Cos., 5/824 .................. 193, 228

Moosejaw Board of Trade, Complaint $r e$ Coal rates, 10/241 ... 117, 169

Mountain Lumber Manufacturers' Association vs. Canadian Pacific Ry. (Golden Toll Case), 17 C.R.C. $285 \ldots \ldots \ldots \ldots \ldots \ldots \ldots \ldots$........... 182

Nanaimo Board of Trade vs. Canadian Pacific Ry. Co., 11/288; VI J.O.R.R. 9. ........................ 145, 214 North Bay Interchange Traffic Case, VI J.O.R.R.[4........ 219, 229

Oliver-Serim Lumber Co. vs. Canadian Pacific and Esquimalt \& Nanaimo Ry. Cos., 17 C.R.C. $324 \ldots \ldots \ldots \ldots \ldots \ldots \ldots$ 171, 228 Ontario Fruit Growers' Association vs. Canadian Pacific Ry. Co. et al., 1/69; 3 C.R.C. $430 \ldots \ldots \ldots \ldots \ldots \ldots \ldots \ldots \ldots \ldots \ldots \ldots \ldots$ Herbert Oyler vs. Dominion Atlantic Ry., 11/ $237 \ldots \ldots \ldots \ldots \ldots 167$ 
Palmer vs. Grand Junction Ry. Co., 4 M. \& W. 749

Panama Canal rates and transcontinental traffic, $11 / 183 . \ldots \ldots$ 14i 2 , 210

Pea Millers' Association vs. Canadian Ry. Cos., 1/70; 3 C.R.C. 433214

James Pendor \& Co., Complaint $r e$ rates on iron goods from St. John,

N.B., 8/47 (File 10720)......................... 124

Plain \& Company vs. Canadian Pacific Ry. Co., 5/208; 9 C.R.C. 222150

Plymouth Cordage Co. vs. Grand Trunk Ry. Co. et al., 5/242; 7/237; 13 C.R.C. 140............................

Portage Board of Trade, Complaint against special freight tariffs of the Canadian Pacific Ry. Co., 4/265; 8 C.R.C. 180...... 173, 204

Port Arthur and Fort William Boards of Trade vs. Canadian Pacific

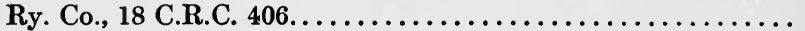

Quebec Central Ry., re jurisdiction of the Board, 9/139......... 228

Rat Portage Lumber Co. vs. Canadian Northern Ry. Co., 6/215 ... 193 Red Mountain Ry. Co. vs. Columbia and Western Ry. Co., 5/229.. 125 Regina Board of Trade vs. Canadian Pacific Ry. Co. et al. (Regina Rate Case), 6/169; 7/248; 9/277; 11 C.R.C. $380 \ldots \ldots \ldots \ldots 177,178$

Richardson \& Sons, Complaint re grain rates from Kingston, 4/302 180 Riley vs. Dominion Express Company, 17 C.R.C. 113 .......... 227

Riverside Lumber Co., Limited, Complaint $r e$ rates charged by the Canadian Pacific Ry. Co. from Viceroy to Assiniboia, 10/202.... 213

Roberts, E. W., Complaint against the Canadian Pacific Ry. Co. for refusal to establish a special winter rate on "rough unpeeled pulp wood," 10/343.

St. David's Sand Co. vs. Grand Trunk and Michigan Central Ry. Cos., 17 C.R.C. 279 .

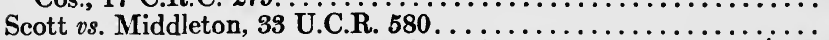

Seaman Kent Co., Limited, vs. Canadian Pacific Ry. Co., 7/254; 13 C.R.C. $420 \ldots \ldots \ldots \ldots \ldots \ldots \ldots \ldots \ldots \ldots \ldots \ldots$ 133, 197

Shingle Agency of British Columbia; Application re complement of nails with shingle shipments, VI J.O.R.R. 457 ......... 211 Application for stop-over privilege, VI J.O.R.R. $488 \ldots \ldots \ldots \ldots$...... 211 Sinclair, C. M., Complaint on freight charges on household effects,

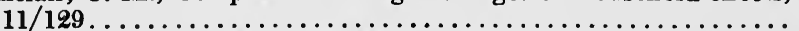

Spanish River Pulp \& Paper Mills, Limited, Complaint re overcharge on shipments of machinery, $11 / 259 ; 19$ C.R.C. $381 \ldots \ldots 204$

Stamford Junction Case, 3 C.R.C. $256 \ldots \ldots \ldots \ldots \ldots \ldots \ldots \ldots \ldots$

Stockton \& Mallinson vs. Canadian Pacific Ry. freight rates, 5/207; 9 C.R.C. $165 \ldots \ldots \ldots \ldots \ldots \ldots \ldots \ldots \ldots \ldots \ldots$ 99, 124

Stockton \& Mallinson vs. Dominion Express Company, 8/276 .... 232

Sudbury Board of Trade vs. Canadian Pacific Ry. Co., 5/277 ..... 168

Sudbury Brewing and Malting Co. vs. Canadian Pacific Ry. Co. re Milling-in-transit privilege, 11/101; 18 C.R.C. 410 ... 193, 211,212

Supplement No. 1 to the Canadian Classification No. 15, Application for approval of, $r e$ ratings on Tobacco, 6/221.......... 133

Sydenham Glass Company vs. Grand Trunk Ry. Co. et al., 1/67;

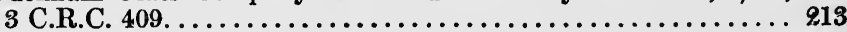

Taylor Co. and the Canada Flour Mills vs. Canadian Pacific and Père Marquette Ry. Cos., VI J.O.R.R. 23.............. 190 
Telegraph Tolls Case, VI J.O.R.R. 29 ff.

$86,111,112,113,169,170,177,178,180,185,205,207$

Tower Oiled Clothing Co., Application for carload rating on oiled clothing, 1/69; 8 C.R.C. $417 \ldots \ldots \ldots \ldots \ldots \ldots \ldots \ldots \ldots, 188$

Traffic Congestion, VI J.0.R.R. 462................... 223

Two Creek Grain Growers' Association vs. Canadian Pacific Railway, 11/156; 18 C.R.C. $403 \ldots \ldots \ldots \ldots \ldots \ldots \ldots \ldots \ldots . \ldots \ldots$

United Factories, Limited, vs. Grand Trunk Ry., 1/69; 3 C.R.C. 424214

Vancouver Eastbound vs. Winnipeg Westbound rates, 3/133; 7 C.R.C. $125 . \ldots \ldots \ldots \ldots \ldots \ldots \ldots \ldots \ldots \ldots \ldots$ 141, 153, 181

Vancouver - Prince Rupert Meat Co. vs. Great Northern Ry. Co., $7 / 233$

Weganost vs. Grand Trunk Ry. Co. (Brampton Commutation Rates Case No. 1), 4/845; 8 C.R.C. 42.................... 206

Western Ontario Municipalities vs. Grand Trunk Ry. Co. et al.,

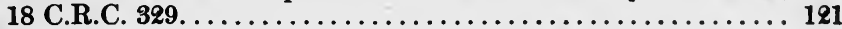

Western Rates Case, File 18755, 17 C.R.C. 123,

$93,105,106,107,135,153,179$

E. Williams \& Co. et al., Complaint against rates on stone from Stonewall to Winnipeg, $1 / 73 \ldots \ldots \ldots \ldots \ldots \ldots \ldots \ldots$ 99, 215

Winnipeg Jobbers' Association vs. Canadian Pacific Ry. Co. et al. (Winnipeg Rate Case), 4/263; 8 C.R.C. 175.............. 204

Wire Fencing, Commodity rates on, 8/58; 14 C.R.C. $377 \ldots \ldots \ldots 180$

Wood Ashes, Complaint of Chas. Stevens against rates, VI J.O.R.R.

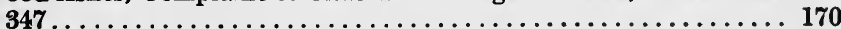

Wylie Milling Co. vs. Canadian Pacific Ry. Co. and Kingston and Pembroke Ry. Co., 7/250; 14 C.R.C. 5............ 155, 288 



\section{INDEX}





\section{INDEX}

Acworth, W. M., 50.

Allan, Hugh, 38.

Arbitraries, 61, 68.

Atlantic \& St. Lawrence Railway, 77.

Blair, Hon. A. G., 84.

Blake, Hon. Edward, 41.

Board of Railway Commissioners for Canada, possible limitations on power, 68-71, 73; " independent" tribunal recommended, 79-80; establishment and powers conferred, 83-94; regulative powers, 233; control of rates, 237; laissez-faire point of view, 200, 238.

Branch line rates, 163-67, 237.

British Columbia, 36, 37.

British Yukon Railway Company, n. 101.

Buckingham and Chandos letter re line of the Intercolonial Railway, 30.

Calgary \& Edmonton line, 43.

Canadian Express Company, 120.

Canadian Freight Association, 58.

Canadian Northern Railway, history, 48-51; government aid received, 52,157; effect of rate reductions, 105, 106, 109; telegraph line, 112, 114; express company, $120,148,235$.

Canadian Pacific Ocean Service Company, 44.

Canadian Pacific Railway history, 38-44, 50, 57, 69; Crowsnest Pass Railway agreement, 78, 102, 105, 109; telegraph company, 112; possibility of secret reserve, 115 , 190-91, 235.

Canadian Railway Act, 88-92.

Canadian rate territories, 59 .

Canals, 8-13, 15, 148.
Capital, need for, Canadian Railways, 110.

Carload and less than carload shipments, 186-89.

Cartage tolls, 125.

Cartwright, Sir Richard, 37.

Central Freight Association, 61.

Chambly Canal, 10.

Champlain \& St. Lawrence Railway, 76.

Charter restrictions on rates, 73, 76-79.

Chicago \& Grand Trunk Railway, 116.

Class tariffs, 61, 83.

Classification, Canadian described, 58-69; official classification, 61, 147; uniform classification suggested, 80; grievances investigated, 83; Board's control over, $91,93,198$.

Coal rates, 65-66, 183, 218.

Commercial policy, Montreal and New York, 4, $n$. 6; waterways v8. railways, 27; in the Northwest, 35,53 ; transcontinental traffic, 63; coal and grain, 66; effect of rival American lines on regulation, $69,203,214,215,224$, 237.

Commodity rates, $61,64-68,175$, 205.

Common law on rates, 73-76.

Commutation rates, $121,206-07$, 225.

Competition, recognized by statute, 91, 137; water competition, 13654; rail competition, $154-56,161$; long and short haul and competition, 175; "pervasive" competition, 176; competition and interswitching, 191; competition for traffic, 203, 216-26; 237.

Conservative policy re the Pacific Railway, 39. 
Corn Laws, effect of repeal on Canadian industry, 18.

Cost factors and excessive rates, original cost, 101-11; cost of reproduction, 112; cost of maintenance, $123 . f$. ; net increase, 125 ; widened basis of discretion, 12732 ; cost factors and discrimination, 163-94; branch line traffic, 163-67; joint movements, 16778; long vs. short haul, 169; density of traffic, 177; gradients, 181-83; volume, 185; C.L. and L.C.L., 186-89; special services, 189; interswitching, 190; newspaper, 194, 237.

Crowsnest Pass Railway, 44; agreement, 78.

Density of traffic, influence on rates in Western Canada, 150; does not affect standard tariffs, 166; discussed, 180.

Depreciation, 112.

Developmental rates, 202-16; discussed, 225, 237.

Discretion of railway companies in meeting competition, 137, 143$44,151,153,157,162,214$; in granting commodity and developmental rates, 205, 209-10, 21315; commutation ticket rates, 206-08; milling in transit privileges, 211-12; discussed, 212, 22426, 237.

Discrimination, c. vII, 134-200; 75, $79,83,91,97,98,203-08,213$, 223; discussed, 237, 239.

Distance, 126, 166-67, 177-80, 181, 183, 237.

Distributive centers, 61-62.

Dominion Government, 46, 49, 50, $52,76,78,79$ ff. , 108, 235.

Drayton, Sir H. L. (Chief Commissioner), 50, 108, 109, 119.

Duluth, South Shore \& Atlantic Railways, 43, 440.

Earnings, ratio of net to gross, 120 $21,122$.

Edmonton, Dunvegan and British Columbia Railway, n. 56, 122.

English Act, 1845, 79.
English precedents, 99, 227-28.

Erie Canal, 6, 8, 19.

European and North American line, 21.

Excessive rates, c. vi, 97-133; fair return, $101 \mathrm{ff}, 209,237,239$.

Export rates, 161-63, 217.

Express rates, 119-21.

Fair return on investment, 101-22; discussed, 235-36.

Fielding, Hon. W. S., n. 47.

Galt, Hon. A. T., 20.

Gazette, Montreal, $n .77$.

Georgian Bay Canal, 148.

Globe, Toronto, 41.

Government ownership, 32, 237.

Governor-in-Council, 79, 87, 101, $102,201$.

Grades, 181-83.

Grain rates, 66-67.

Grand Trunk Pacific Railway history, 44-48, 50, 53; clay belt, 55 , 57, 105, 106, 109; Telegraph Co., 112; debt to Grand Trunk, 117, 148, 235-37.

Grand Trunk Railway, 17; history, 24-28; reorganized, 28,69 ; estimated and actual cost, $42,45,48$, $49,50,52,116-19,190-91$.

Great North Western Telegraph Company, 112.

Great Western Railway, 22, 28, 33; Act, $n$. 74 .

Grey, Earl, Colonial Secretary, 21. Group rates, 183-85.

Haggart, Hon. John, 81.

Heated car service, 190.

Hincks, Hon. Francis, $n$. 19, $22 \mathrm{ff}$.

Howe, Joseph, 21 ff., $n$. 34 .

Hudson Bay Company, 36.

Hudson's bay route, 149-50, 236.

Hull Electric Railway, 121.

Icing charges, 190.

Import rates, 131.

Industrial development, effect of commission on, 238.

Intercolonial Railway, 17, 22; construction, 28-32, 53, 139. 
International rates, 68, 92, 116, Northern Railway, 33. 230-32.

Interoceanic Railway, 38.

Interstate Commerce Commission, $80,99,147,231$.

Interswitching, 93, 125, 190-93.

Joint rates, 68, 92, 162, 167-76; for express companies, 170, 222, 237.

Judicial aspect of Board's practice, 226, 239.

Laurier, Sir Wilfrid, $n .42,46$.

Legal rate, 176.

Liberal party, policy re Pacific Railway, 37, 38, 41; Grand Trunk Pacific, 46.

Long and short haul, revision of 1888,81 ; Act of 1903, 91, 156; discussed, 169-76.

Long haul, originating corner's right to, in joint routes, 217-23.

Lumber rates, 67 ; mileage equivalents, 182; group rates, 184.

MacDonald, Sir John A., $n .35,40$, 42.

Mackenzie, Hon. Alexander, $n .37$, 38-39.

Mackenzie, Wm., 49.

MacMurchy and Dennison, $n$. 75; quoted, 84, 85.

Main trunk line, 17, 20, 22.

Mann, D., 49.

Market or trade competition, 15661, 162, 202, 203.

McLean, S. J. (Professor, later, Commissioner), Report on Grievances, 82-83, 128, 129, 187.

McPherson, L. G., 170.

Michigan Central Railway, 154.

Military considerations, $6,11,29$, 36.

Milling-in-transit, 67, 193, 198, 199, 211-12.

Mills, Commissioner, 165, 186.

Montreal-Vancouver rate, 63.

Municipal Loan Act, 25.

National Transcontinental Railway, 44-48, 50, 118.

Navigation Laws, 9.

North Shore Railway, 43.

Northwest, complaints, $81,82$.

Northwest Territories Navigation and Railway Company, n. 36.

Official classification, $61,147$.

Oil rates, 68.

Ontario Hydro-Electric Commission, 118.

Ontario \& Quebec Railway, 43.

Ottawa River, 11, 67.

Pacific Railway, 34, $37 f f$.

Paish, Sir George, 50.

Panama Canal, 63, 142, 210, 21718.

Papineau, L. J., $n$. 77.

Parliament, 108, 148, 209, 235.

Physical valuation, 103-10, 112-15, 118, 119, 121.

Pooling, 91.

Precedents, 219, 223, 227-30.

Presumption of reasonableness, 99, 123, 128, 129, 205, 215, 229.

Privy Council. See Governor-inCouncil.

Provincial Governments, aid to Canadian Northern Railway System, 52.

Public policy, rate theory and, 108 , c. vIII, 201-34.

Railways: development confederation provinces, c. II, 17-33; era of transcontinentals, c. III, 3451 ; eff ect on waterway routes, 19 ; first in Canada, 20; minister of, 89 ; railway nets, $33,54,56,58$. Acts: 1851,$79 ; 1888,79 ; 1903$, 83; Amendment of 1908, 84-86; other amendments, $88 ; 1859,89$; Committee of the Privy Council, $80,82,85,94$; commissions of inquiry, 1888, 79-81; 1895, 81; 1899, 82-83; 1916, 50.

Rebates, 174.

Regina \& Prince Albert line, 43.

Rehearings, 233.

Richelieu River, 10.

Rideau Canal, $n .6,11-12,53$.

Robinson, Major, survey, 21.

Ross, Hon. John, 24.

Routing, $n$. 174. 
Safety and protection, provisions for, 86,90 .

St. Andrews \& Quebec Railway, 76.

St. Lawrence \& Atlantic Railway, 28.

St. Lawrence and Industry Railway, 77.

St. Lawrence River, 3, 7, 9 ff., 19, $25,26,27$.

St. Ours Canal, 11.

St. Paul, Minneapolis \& Sault Ste. Marie Railway, 43, 44.

Sault Ste. Marie Canal, 14.

Simcoe, Governor, 6.

Smith, A. H., 50.

Smithers, Alfred W., 48.

Special class rates, 62.

Standard tariffs, 60.

Statutory control of railways, 73, $75,79-94$.

Stock-watering, 109.

Stopovers. See Milling-in-transit. Sugar rates, 67.

Supreme Court, power to review, 85; appeals to, 87, 178, 233, 234. Switching to sidings, $n$. 190.

Talbot, Colonel, 6 .

Tariffs, 92, 93.

Telegraph tolls, 111-13, 184.

Through rates. See Joint rates.

Tolls, and traffic, powers of the Board, 90-92.
Ton-mile rate, 130,165

Town tariffs, 61.

Transcontinental railways, c. III, 34-51, 140, 142, 210, 217, 236.

Trent Affair, 30.

Trout, $n .20$.

Tupper, Sir Charles, 37, n. 46.

Valuation. See Physical valuation.

Value of the commodity, 132-33, 194-200.

Volume of traffic, 127, 185-86, 215, 237. See Density.

Wabash Railway, 154.

War of 1812-14, effect on routes, 6 . Water competition, 67, 138-54; self-regulative, 142; effect on powers of Board, 142-43, 147-48; benefits of, 146; must be efficient, 150; intermittent character recognized, 151; potential water competition, 153; discretion of railways in meeting, 141-42, 214 . Waterways, c. I, 3-16, n. 54, 57, 148.

Welland Canal, 8-9, 14, 19, 149.

White Pass and Yukon Railway, 101-04, 106-07, 109-11.

Zones system, standard tariffs, 60; for telegraph tolls, 184. 


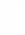







\section{$\mathrm{HE}$ \\ 1855}

M2
MacGibbon, Duncan Alexander Railway rates and the Canadian Railway Commission

\section{PLEASE DO NOT REMOVE CARDS OR SLIPS FROM THIS POCKET}

\section{UNIVERSITY OF TORONTO LIBRARY}


